ALTEMAR FELBERG

\title{
AUTONOMIA E DESENVOLVIMENTO COMUNITÁRIO NO/DO CAMPO: contradições e consensos no Assentamento Luís Inácio Lula da Silva, do Movimento Sem Terra - MST - em Santa Cruz Cabrália - Bahia/Brasil
}

Orientador: Prof. Doutor Geovani de Jesus Silva

\author{
Universidade Lusófona de Humanidades e Tecnologias \\ Faculdade de Ciências Sociais, Educação e Administração \\ Instituto de Educação
}

Lisboa

2016 


\title{
AUTONOMIA E DESENVOLVIMENTO COMUNITÁRIO NO/DO CAMPO:
} contradições e consensos no Assentamento Luís Inácio Lula da Silva, do Movimento Sem Terra - MST - em Santa Cruz Cabrália - Bahia/Brasil

\author{
Dissertação defendida em provas públics para a \\ obtenção do grau de Mestre em Ciências da Educação \\ conferido pela Universidade Lusófona de \\ Humanidades e Tecnologias (ULHT),com o Despacho \\ Reitoral $n^{\circ} 438 / 2016$ com a seguinte composição de \\ Júri: \\ Presidente - Professor Doutor Óscar Conceiçao de \\ Sousa \\ Arguente - Professora Doutora Maria Neves Gonçalves \\ Orientador: Professor Doutor Geovani de Jesus Silva \\ Co- Orientador: Professor Doutor António Teodoro
}

Universidade Lusófona de Humanidades e Tecnologias

Faculdade de Ciências Sociais, Educação e Administração

Instituto de Educação

Lisboa 
Aos companheiros e companheiras do Assentamento Luís Inácio Lula da Silva (Lulão), do Movimento dos Trabalhadores Rurais Sem Terra

(MST), sujeitos e coautores deste trabalho.

A todos os idealizadores e colaboradores do Instituto Mãe Terra, sujeitos que acreditam no desenvolvimento de comunidades por meio do apoio às suas organizações, práticas e estratégias sociais próprias, sempre na perspectiva do empoderamento comunitário e formação para autonomia, acreditando, respeitando e disseminando no território os valores da vida, autonomia, liberdade e democracia.

À minha mãe, que em sua humilde sabedoria, tantas vezes me fez encontrar-me, quando muitas vezes tentaram me roubar de mim. 


\section{AGRADECIMENTOS}

Ao Senhor Meu Deus: minha rocha, minha fortaleza, meu refúgio e meu libertador.

À minha família: mãe, irmãos, cunhados e sobrinhos, que sempre me incentivaram a estudar e a perseguir meus objetivos; que com todo o amor e compreensão, cederam preciosas horas de convívio, permitindo-me mergulhar neste projeto e alcançar este sonho.

A Felício, meu raio de sol, minha tempestade do bem, que com sua leveza e serenidade, me oportunizou a paz de espírito necessária ao desenvolvimento deste trabalho.

Aos companheiros e companheiras do MST (Preto, Jazi, Antônio, Glória, Maria Gil e tantos outros), sujeitos e coautores deste trabalho, que sempre se mostraram solícitos e cordiais aos meus pedidos, relatando suas vivências com verdade e convicção.

Ao meu mestre, orientador e amigo, Geovani de Jesus Silva, que com toda a sua sensibilidade e conhecimento, soube fazer as críticas e exigências necessárias a esta pesquisa, orientandome e motivando-me rumo à conclusão desta obra.

Ao meu co-orientador, Professor António Teodoro, por todo o apoio e incentivo.

Aos meus colegas de jornada de curso, em especial aos persistentes teimosos (Ana Joaquina Brito, Erotides, Everaldo, Flaelma, Glaci, Marcos, Padre Manoel, Soraia e Tatiana), por todo o apoio, paciência, contribuições e solidariedade.

À Calitta, Mariana e Felício, pela rica contribuição na tarefa de coleta dos dados.

A Elismar, por todo o suporte e apoio, não apenas neste projeto, mas em muitos outros.

E, finalmente, às pessoas e situações que hoje me fazem reconhecer a grandeza e beleza de vencer opressões e de me assumir como um sujeito autônomo e livre. 
"Há caminhos de desenvolvimento, não há um caminho de desenvolvimento. Isso tem que ver, justamente com as questões da descentralização e com a valorização da participação e da autonomia, entendida não como autossuficiência, mas como capacidade de integrar o exógeno, aquele que vem de fora, como um adubo para o endógeno. Trata-se de valores que as sociedades industriais não fomentaram: a participação cedeu o lugar à representação política; a solidariedade ficou para os moralistas, porque a competitividade e a concorrência foram julgadas mais interessantes e eficientes. (...) A autonomia também não foi fomentada, porque o que se criou foram relações de dependência, num quadro de hierarquização, sem uma relevante participação de cada um na tomada de decisões" (Amaro, 1996, p. 18). 


\section{RESUMO}

Buscamos, neste trabalho, compreender de que modo os indicadores de desenvolvimento comunitário rural do Assentamento do Movimento dos Trabalhadores Rurais Sem Terra (MST), Luís Inácio Lula da Silva, localizado no município de Santa Cruz Cabrália, Território de Identidade Costa do Descobrimento - Bahia, refletem o grau de autonomia de seus moradores, homens e mulheres do campo, destacando, nessa relação, o papel da educação no processo de formação de sujeitos autônomos. Adotamos a pesquisa qualiquantitativa como enfoque metodológico, com a convergência das pesquisas descritiva e exploratória, tendo como instrumentos de coleta de informação, o questionário, entrevistas semiestruturadas e grupos focais. Como categorias teórico-analíticas, elegemos: Primeiro, a autonomia, entendida como a capacidade do indivíduo governar-se conforme uma lei própria, de maneira livre e racional, conduzindo-se à dignidade humana. Pode ser compreendida como um poderoso recurso capaz de livrar os indivíduos não só da submissão a processos heterônomos, que interferem sobre suas liberdades de escolha e ação, mas também dos quadros de vulnerabilidade socioeconômica, devendo ser considerada como importante medida na avaliação do desenvolvimento, conforme os estudos de Kant (1974), Castoriadis (1991), Adorno (1984), Paulo Freire (1986), Marilena Chauí (1990), dentre outros. Segundo, a educação do campo, que conforme os estudos de Cury (2002), Miguel Arroyo (2004), Roseli Caldart (2004) e Mônica Molina (2004), surge como crítica à realidade do sistema educacional no Brasil, particularmente à situação educacional da população brasileira que trabalha e vive no/do campo, ao modelo de sistema econômico capitalista e sua injusta distribuição de renda, ao incentivo ao agronegócio e à expropriação de terras tradicionais, à elitização do acesso à ciência, à tecnologia, à cultura e às suas produções, enfim, críticas a não universalização de direitos que garantem a plena cidadania. Terceiro, e último, o desenvolvimento comunitário rural, que se configura como um processo através do qual a comunidade amadurece em relação a si mesma, reconhece suas fragilidades e potenciais de desenvolvimento, rompe seus casulos e se transforma em novas possibilidades de ser (SILVA; ARNS, 2002). Na visão de autores como Favareto (2006), José Eli da Veiga (2005; 2006), Amartya Sen (2008), Ignacy Sachs (2000), este tipo de desenvolvimento é identificado por meio de indicadores que ultrapassam o mero crescimento econômico, levando em consideração aspectos avaliativos como acesso a oportunidades sociais, liberdades políticas e também facilidades econômicas. Assim, na pesquisa discutimos e analisamos os diversos aspectos que envolvem estas três categorias, estabelecendo as inúmeras possibilidades de relação entre elas, buscando compreender o desenvolvimento e exercício da autonomia, a partir dos contributos da educação do campo, rumo ao 'desenvolvimento como liberdade'. A análise parte do entendimento de que não se pode alcançar o desenvolvimento à custa da privação do outro, mas a partir do reconhecimento de que o desenvolvimento é influenciado positivamente pelo acesso às oportunidades econômicas, liberdades políticas, poderes sociais e por condições habilitadoras, especialmente por meio da educação. Seja no sentido da autonomia para os sujeitos, seja na dimensão social desta, concluímos que os indicadores de desenvolvimento da comunidade estudada têm relação direta com o elevado grau de autonomia de seus moradores, uma autonomia forjada no próprio espaço de vivência, construída na práxis educativa da luta por direitos e por uma vida digna, uma autonomia utilizada a favor da coletividade.

Palavras-Chave: Autonomia; Educação do Campo; Desenvolvimento Comunitário Rural. 


\begin{abstract}
In this study we seek to understand how the rural community development indicators of the settlement of the Rural Workers Landless Movement (MST), Luis Inacio Lula da Silva, in the municipality of Santa Cruz Cabrália, Território de Identidade Costa do Descobrimento Bahia, reflect the degree of autonomy of its residents, men and women from the field, highlighting, in this regard, the role of education in the formation of autonomous individuals. We adopt a qualitative-quantitative research as a methodological approach, with the convergence of descriptive and exploratory research, and the following data collection instruments, the questionnaire, semi-structured interviews and focus groups. As theoretical and analytical categories, we elected: First, autonomy, understood as the individual's ability to govern itself according to its own law, free and rational way, leading himself to human dignity. Can be understood as a powerful resource able to deliver individuals not only submission to heteronomous processes that interfere on their freedom of choice and action, but also the socio-economic vulnerability of frames, should be considered as an important measure in assessing the development, according to the studies of Kant (1974), Castoriadis (1991), Adorno (1984), Paulo Freire (1986), Marilena Chauí (1990), among others. Second, the rural/field education, which according to the studies of Cury (2002), Miguel Arroyo (2004), Roseli Caldart (2004) and Monica Molina (2004), appears as critical the reality of the educational system in Brazil, particularly the educational situation of the population that works and lives in the/of the field, the capitalist economic system model and its unfair distribution of income, the incentive to agribusiness and the expropriation of traditional lands, the elitization of access to science, technology, culture and their products, finally, criticism of not universal rights that guarantee full citizenship. Third, and last, rural community development, which is configured as a process through which matures community in relation to itself, recognize its weaknesses and potential for development, breaks their cocoons and turns into new possibilities of being (SILVA; ARNS , 2002). In the view of authors like Favareto (2006), José Eli da Veiga (2005; 2006), Amartya Sen (2008), Ignacy Sachs (2000), this type of development is identified through indicators that go beyond the mere economic growth, but considering evaluative aspects such as access to social opportunities, political freedoms and also economic facilities. Thus, the research discussed and analyzed the various aspects involved in these three categories, establishing the countless possibilities of relationship between them, trying to understand the development and exercise of autonomy, from rural/field education contributions, towards 'development as freedom'. The analysis begins with the understanding that you can not achieve development at the expense of deprivation of the other, but from the recognition that development is positively influenced by access to economic opportunities, political liberties, social powers and enabling conditions, especially through education. Be towards autonomy for the subjects, whether in the social dimension of this, we conclude that the studied community development indicators are directly related to the high degree of autonomy of its residents, an autonomy forged in their own living space, built in the educational praxis the struggle for rights and a dignified life, an autonomy used in favor of the community.
\end{abstract}

Keywords: Autonomy; Rural/Field Education; Rural Community Development. 


\section{LISTA DE FOTOGRAFIAS}

Fotografia $01-1^{a}$ Reunião com Lideranças do MST - 12/10/2015 …..................................55

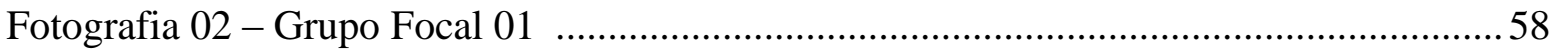

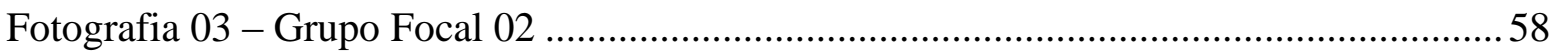

Fotografia 04 - Entrada do Assentamento Lulão ................................................................... 142

Fotografia 05 - Agroindústria de Beneficiamento de Frutas ............................................ 143

Fotografia 06 - Cozinha de Doces e Compotas ............................................................. 144

Fotografia 07 - Unidade Básica de Saúde (PSF11 Lulão) ................................................... 146

Fotografia 08 - Escola Municipal Paulo Freire ................................................................ 147

Fotografia 09 - Unidade de Tratamento e Abastecimento de Água...................................... 149 
Altemar Felberg - Autonomia e Desenvolvimento Comunitário NO/DO Campo: Contradições e Consensos no Assentamento Luís Inácio Lula da Silva, do Movimento sem Terra - MST - em Santa Cruz Cabrália - Bahia/Brasil

\section{LISTA DE QUADROS}

Quadro 01 - Principais Características do Desenvolvimento 140

Quadro 02 - Principais Características do Desenvolvimento no Lulão 141

Quadro 03 - Índice de Desenvolvimento Comunitário Rural do Assentamento Lulão 150 
Altemar Felberg - Autonomia e Desenvolvimento Comunitário NO/DO Campo: Contradições e Consensos no Assentamento Luís Inácio Lula da Silva, do Movimento sem Terra - MST - em Santa Cruz Cabrália - Bahia/Brasil

\section{LISTA DE TABELAS}

Tabela 01 - Acesso dos Assentados/as aos meios de comunicação .54

Tabela 02 - Acesso dos Assentados/as a espaços de cultura, lazer e entretenimento .54 


\section{LISTA DE GRÁFICOS}

Gráfico 01 - Faixa geracional entre homens e mulheres................................................50

Gráfico 02 - Nível de escolaridade dos sujeitos pesquisados ............................................51

Gráfico 03 - Sentido da autonomia para as mulheres ........................................................ 91

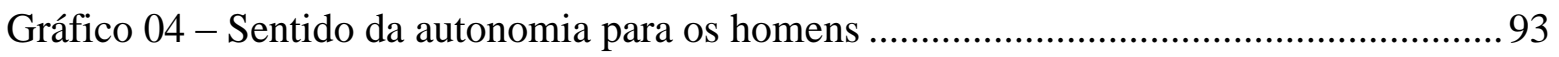

Gráfico 05 - Dimensão social da autonomia para as mulheres - trabalho e renda / cadeia produtiva / segurança alimentar ............................................................... 96

Gráfico 06 - Dimensão social da autonomia para os homens - trabalho e renda / cadeia produtiva / segurança alimentar 97

Gráfico 07 - Dimensão social da autonomia para as mulheres - qualificação de mão-de-obra 99

Gráfico 08 - Dimensão social da autonomia para os homens - qualificação de mão-de-obra 100

Gráfico 09 - Dimensão social da autonomia para mulheres - participação social . 102

Gráfico 10 - Dimensão social da autonomia para os homens - participação social. 103

Gráfico 11 - Dimensão social da autonomia para mulheres - educação 117

Gráfico 12 - Dimensão social da autonomia para os homens - educação 118

Gráfico 13 - Relação com o meio ambiente. 150

Gráfico 14 - Grau de satisfação da infraestrutura local 


\section{LISTA DE ABREVIATURAS E SIGLAS}

ACAR

BNDES

CEPDES

$\mathrm{CNBB}$

CNER

CNPJ

CONTAG

CPT

EGM

EJA

EMBRAPA

ENERA

ETENE

FEAB

FETRAF

FLONIBRA

IBGE

IDH

IDHM

IICA

INCRA

INEP

IPM

LULÃO

MAB

MDA

MEB

MMC

MPA

MST
Associação de Crédito e Assistência Social

Banco Nacional de Desenvolvimento Social

Centro de Estudos e Pesquisas em Emergências e Desastres em Saúde

Conferência Nacional dos Bispos do Brasil

Campanhas de Educação Rural

Cadastro Nacional de Pessoa Jurídica

Confederação Nacional dos Trabalhadores da Agricultura

Comissão Pastoral da Terra

Brigada Elias Gonçalves de Meura

Educação de Jovens e Adultos

Empresa Brasileira de Pesquisa Agropecuária (EMBRAPA)

Encontro Nacional de Educadores e Educadoras da Reforma Agrária

Escritório Técnico de Estudos Econômicos do Nordeste

Federação dos Estudantes de Agronomia

Federação dos Trabalhadores da Agricultura Familiar

Floresta Nipônica Brasileira

Instituto Brasileiro de Geografia e Estatística

Índice de Desenvolvimento Humano

Índice de Desenvolvimento Humano Municipal

Instituto Interamericano de Cooperação para a Agricultura

Instituto Nacional de Colonização e Reforma Agrária

Instituto Nacional de Estudos e Pesquisas Educacionais Anísio Teixeira

Índice de Pobreza Multidimensional

Assentamento Luís Inácio Lula da Silva

Movimento dos Atingidos por Barragens

Ministério do Desenvolvimento Agrário

Movimento de Educação de Base

Movimento das Mulheres Camponesas

Movimento dos Pequenos Agricultores

Movimento dos Trabalhadores Rurais Sem Terra 
NASF

ONU

PIB

PIC LEADER

PJR

PNUD

PPP

PRONAF

PRONERA

SEBRAE

SECAD

SENAR

UBS

UESC

ULHT
Núcleo de Apoio à Saúde da Família

Organização das Nações Unidas

Produto Interno Bruto

Programa de Iniciativa Comunitária: Ligação Entre Ações de Desenvolvimento da Economia Rural

Pastoral da Juventude Rural

Programa das Nações Unidas para o Desenvolvimento

Projeto Político Pedagógico

Programa Nacional de Fortalecimento da Agricultura Familiar

Programa Nacional de Educação na Reforma Agrária

Serviço de Apoio às Micro e Pequenas Empresas

Secretaria de Educação Continuada, Alfabetização e Diversidade

Serviço Nacional de Aprendizagem Rural

Unidade Básica de Saúde

Universidade Estadual de Santa Cruz

Universidade Lusófona de Humanidades e Tecnologias 


\section{INDÍCE}

INTRODUÇÃO ...................................................................................................................15

CAPÍTULO I - CONTEXTUALIZAÇÃO DO OBJETO E PANORAMA GERAL

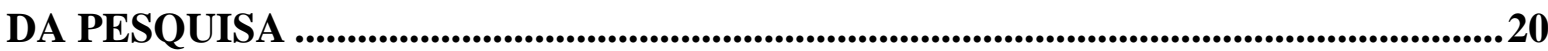

1.1 Assentamento Luís Inácio Lula da Silva (Lulão): a terra conquistada .............................28

1.2 Autonomia: uma condição do sujeito de "ser para si"...................................................... 31

1.3 Educação do Campo: a luta por uma educação diferenciada ...............................................38

1.4 Desenvolvimento e Desenvolvimento Rural: conceitos e delimitações ............................42

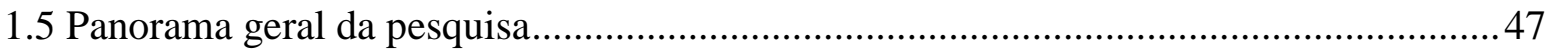

1.5.1 Caracterização da Pesquisa................................................................................ 48

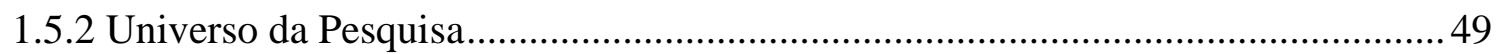

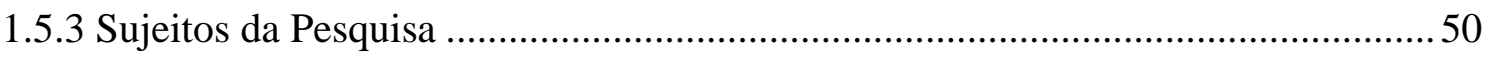

1.5.4 Instrumentos e Procedimentos de Coleta de Informações..........................................55

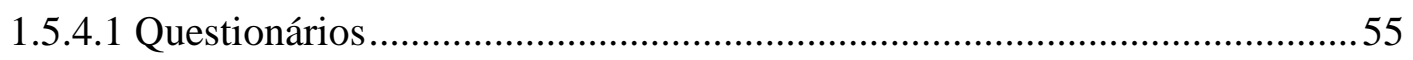

1.5.4.2 Grupos Focais ....................................................................................5

1.5.5 Procedimentos de Análise de Informações............................................................59

CAPÍTULO II - AUTONOMIA NA CONTEMPORANEIDADE: O "PENSAR AUTÔNOMO" SEGUIDO DO “FAZER AUTÔNOMO" ..................................................62

2.1 Contexto Sócio-Histórico e Político de Desenvolvimento e Exercício da Autonomia ...74

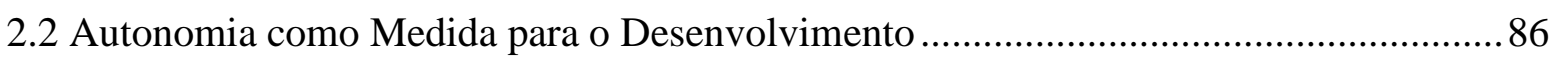

2.3 Sentido da Autonomia para os Moradores do Assentamento Luís Inácio Lula da Silva 90

2.4 Dimensão Social da Autonomia: percepção da vida em comunidade...............................95

CAPÍTULO III - EDUCAÇÃo DO CAMPO E A FORMAÇÃo DE SUJEITOS AUTÔNOMOS .............................................................................................................107

3.1 Educação do Campo: contexto histórico, práticas e sujeitos.............................................112

CAPÍTULO IV - DESENVOLVIMENTO COMUNITÁRIO RURAL ............................122

4.1 A Abordagem Territorial do Desenvolvimento Rural e seus Significados ......................130

4.2 Desenvolvimento Comunitário Rural: histórico, definição e características .....................133

4.3 Indicadores de Desenvolvimento do Assentamento Luis Inácio Lula da Silva ............... 141

CONSIDERAÇÕES FINAIS..................................................................................................155

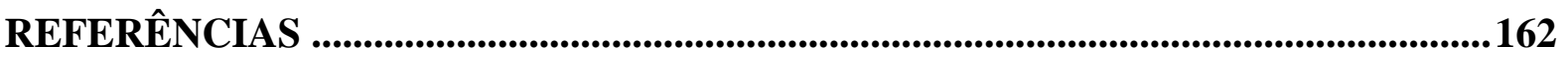


Altemar Felberg - Autonomia e Desenvolvimento Comunitário NO/DO Campo: Contradições e Consensos no Assentamento Luís Inácio Lula da Silva, do Movimento sem Terra - MST - em Santa Cruz Cabrália - Bahia/Brasil

APÊNDICE I 
Altemar Felberg - Autonomia e Desenvolvimento Comunitário NO/DO Campo: Contradições e Consensos no Assentamento Luís Inácio Lula da Silva, do Movimento sem Terra - MST - em Santa Cruz Cabrália - Bahia/Brasil

\section{INTRODUÇÃO}


É pauta cada vez mais presente nas atuais discussões sobre desenvolvimento, a necessidade de participação e engajamento mais qualificados da sociedade civil nos processos do sistema democrático brasileiro. No bojo dessas discussões, a participação social, que nasce da luta por direitos e busca o alcance e exercício da autonomia, é considerada pelos estudiosos como determinante e estratégica para se construir a democracia e alcançar o desenvolvimento socioeconômico do país. Para tanto, o grande desafio é despertamos para a necessidade urgente de uma mudança de comportamento social, a partir do entendimento de que não se pode alcançar o desenvolvimento à custa da privação do outro, mas a partir do reconhecimento de que o desenvolvimento é influenciado, positivamente, pelo acesso às oportunidades econômicas, liberdades políticas, poderes sociais e por condições habilitadoras, especialmente por meio da educação.

Partindo desse pressuposto, trataremos aqui de compreender de que modo os indicadores de desenvolvimento comunitário rural do Assentamento Luís Inácio Lula da Silva, vinculado ao Movimento Sem Terra - MST, no município de Santa Cruz Cabrália, refletem o grau de autonomia de seus moradores, e qual o papel da educação no processo de formação de sujeitos autônomos.

A temática da autonomia, refletida inicialmente pelos historiadores e filósofos gregos, tem ganhado destaque e notoriedade na modernidade, com os estudos de Immanuel Kant (1974), e recebe de Freire (1986) um sentido sócio-político-pedagógico: autonomia como condição sócio-histórica de um povo ou pessoa que tenha se libertado, se emancipado das opressões que restringem ou anulam sua liberdade de determinação. Assim, conquistar a própria autonomia implica em libertação das estruturas opressoras - uma das bandeiras defendidas pelos educadores e educadoras da educação do campo.

É caminhando nesta direção, do "pensar certo e agir certo", ainda segundo Freire (1996), que decidimos externar, por meio dessa pesquisa, nossa vontade de testemunhar ações éticas, assumindo-nos como seres histórico-culturais, ansiosos por mudanças sociais efetivas e duradouras, contempladoras da concretização dos princípios básicos dos direitos humanos, que é, em suma, a universalização dos bens e oportunidades sociais e a prerrogativa da participação popular na construção e usufruto do desenvolvimento, pois "não podemos nos assumir como sujeitos de procura, da decisão, da ruptura, da opção, como sujeitos históricos, transformadores, a não ser assumindo-nos como sujeitos éticos" (FREIRE, 1996, p. 19).

É sob este olhar, da expansão das liberdades do sujeito no atual conceito de autonomia e medição do desenvolvimento, a partir do papel da educação, que firmamos a presente 
pesquisa, cuja escolha da temática decorre, além da experiência profissional na área, do fato de que não se acredita em desenvolvimento real sem autonomia, tampouco se crê na existência de ambos, sem a conquista do poder, do conhecimento que possibilita a percepção crítica da realidade e a reação frente às injustiças sociais. Nesse movimento de ruptura, de ação, é que a educação mostrou-se, ao longo da história, ser uma importante frente de luta, como já dizia Paulo Freire (1986).

Desde 2003, à frente da gestão de organizações não governamentais, atuando na avaliação e monitoramento de empreendimentos sociais, temos nos deparado cotidianamente com a dificuldade dos indivíduos de comunidades rurais, para se descobrirem e se assumirem como sujeitos autônomos, capazes de protagonizar suas próprias histórias de desenvolvimento, pessoal e social, sujeitos de ação e reedição, apesar de todo o investimento institucional em projetos de desenvolvimento comunitário que, em sua maioria, trazem a autonomia, assim como a emancipação e o protagonismo, como seus objetivos transversais.

Não é preciso estar no dia a dia dessas populações para notar o quadro de marginalidade e exclusão em que se encontram, apresentado nacional e localmente, delineado, a nosso ver, sobretudo, dentre outros fatores, pela ineficácia das políticas públicas, principalmente no que tange ao oferecimento de uma educação de qualidade e libertária da dependência e alienação, base primordial para a conquista do poder, em suas várias dimensões, capaz de promover e transformar a sociedade. Um poder, no sentido usado por Freire, como um aumento da conscientização e desenvolvimento de uma "faculdade crítica", um poder de "fazer" e de "ser capaz", bem como de sentir-se com mais capacidade para agir e desempenhar um papel ativo nas iniciativas de desenvolvimento.

Nesse contexto, supõe-se que a restrição da autonomia dos atores sociais que vivem no/do campo, e consequentemente de suas instituições representativas, elidem as possibilidades destes grupos menos favorecidos, de participar ativamente dos processos de discussão, formulação e usufruto efetivos de políticas de desenvolvimento local. Por outro lado, a autonomia construída a partir da expansão das capacidades individuais e coletivas, da reflexão e decisão sobre aquilo que é significativo e de valor para si e para seu grupo, pode ampliar as possibilidades de exercício da cidadania, de luta contra as pressões externas e de desenvolvimento.

Essa situação tem nos preocupado e nos instigado a melhor compreender este fenômeno, o que nos chama a um posicionamento ético no pensar e no agir, não apenas como pesquisador, mas como cidadão. 
Aprofundando a discussão sobre o desenvolvimento comunitário rural, observamos que o assunto tem recuperado seu espaço e ganhado novas análises, a partir do conceito de poder. Analisando alguns dos trabalhos e autores referenciais nesse recente debate ${ }^{1}$, ressaltamos a preocupação dos estudiosos com quatro elementos-chave, a partir dos quais se preconiza a retomada do debate sobre o desenvolvimento rural: a erradicação da pobreza rural, a questão do protagonismo dos atores sociais e sua participação política, o território como unidade de referência e a preocupação central com a sustentabilidade ambiental.

Os conceitos de autonomia e desenvolvimento já têm sido estudados e propostos em grupos subalternizados, juntamente com outros conceitos, como ação coletiva, participação, cidadania, entre outros. Todavia, acreditamos que relacionar estes dois temas com a educação do campo, num assentamento do Movimento dos Trabalhadores Rurais Sem Terra (MST), seja uma pesquisa inovadora, que possa enriquecer o acervo científico sobre o assunto. Corroboramos as afirmações de Monica Molina (2006, p. 10), no I Encontro Nacional de Pesquisa em Educação do Campo, realizado em setembro de 2005, pelo Ministério do Desenvolvimento Agrário, quando a autora destaca a importância de novas produções científicas que privilegiem "a correlação entre a precarização das condições de vida e (re)produção dos diferentes sujeitos presentes no espaço rural [...] e o papel da Educação do Campo na construção de políticas públicas".

Os resultados desta pesquisa foram organizados em 04 (quatro) partes, as quais serão apresentadas a seguir:

No primeiro capítulo, contextualizamos o objeto da pesquisa e apresentamos as categorias teóricas mobilizadas para explicar o fenômeno estudado, ou seja, a evolução dos conceitos de autonomia, de educação do campo e de desenvolvimento comunitário rural. Também são discutidos nesse capítulo, o enfoque metodológico, os procedimentos técnicos utilizados para o alcance dos resultados e as características socioeconômicas e culturais do universo e sujeitos estudados.

O segundo capítulo apresenta o conceito de autonomia na contemporaneidade: o "pensar autônomo" seguido do "fazer autônomo"; contexto sócio-histórico e político de desenvolvimento e exercício da autonomia; e, especialmente, autonomia como medida para o desenvolvimento. Utilizamos, como autores de referência, Castoriadis (1991), Adorno (1984), Paulo Freire (1986), Marilena Chauí (1990), Bobbio (2000), Amartya Sen (2008), dentre outros. Ainda nesse capítulo, apresentamos o sentido da autonomia para os sujeitos da

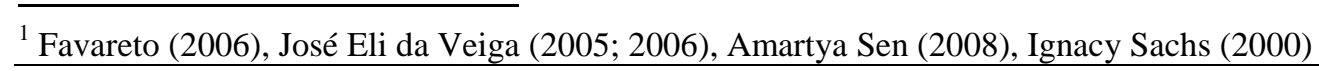


pesquisa, estratificado por gênero, e a dimensão social dessa autonomia (a vida em comunidade), trazendo informações sobre as variáveis: Trabalho, Qualificação e Participação Social.

No terceiro capítulo, discutimos a Educação do Campo e a formação de sujeitos autônomos, tendo Freire (1986), Cury (2002), Miguel Arroyo (2004), Roseli Caldart (2004), Mônica Molina (2004), dentre outros, como autores de referência. O objetivo é defender o direito à educação como instrumento de inclusão social, abordando o movimento social como princípio educativo, destacando o papel formativo do MST e a relação prática entre autonomia e educação, no contex to dos sujeitos pesquisados.

No quarto capítulo trazemos as discussões sobre Desenvolvimento e Desenvolvimento Comunitário Rural, tendo como autores de referência, Favareto (2006), José Eli da Veiga (2005; 2006), Amartya Sen (2008), Ignacy Sachs (2000), dentre outros, os quais lançam novos olhares no campo do desenvolvimento, no contexto da reestruturação capitalista e do desenvolvimento rural no Brasil, considerando sua história, seus significados e contradições. Ainda nesse capítulo, apresentamos as características sociais, políticas, econômicas, ambientais e culturais da comunidade objeto da pesquisa e os seus indicadores de desenvolvimento local.

Não pretendemos, com este estudo, esgotar toda a temática relacionada ao objeto, uma vez que ainda há muito a investigar nesse campo, por isso fica a intenção de contribuir, minimamente que seja, para o enriquecimento da temática, a fim de que, em estudos futuros, possamos levantar outras questões e dialogar com outros sujeitos, no intuito de compreender os modos de vida de homens e mulheres do campo, e do próprio campo, os quais vêm sustentando as cidades brasileiras, sem, contudo, o devido reconhecimento. 
Altemar Felberg - Autonomia e Desenvolvimento Comunitário NO/DO Campo: Contradições e Consensos no Assentamento Luís Inácio Lula da Silva, do Movimento sem Terra - MST - em Santa Cruz Cabrália - Bahia/Brasil

\section{CAPÍTULO I}

CONTEXTUALIZAÇÃO DO OBJETO E PANORAMA GERAL DA PESQUISA 
Analisar de que modo os indicadores de desenvolvimento comunitário rural refletem o grau de autonomia de moradores, homens e mulheres do campo, destacando o papel da educação no processo de formação de sujeitos autônomos, no Assentamento Luís Inácio Lula da Silva, o "Lulão", localizado no município de Santa Cruz Cabrália, Território de Identidade Costa do Descobrimento - Bahia, vinculado ao Movimento dos Trabalhadores Rurais Sem Terra (MST), é revelar o potencial de homens e mulheres campesinos que, após a conquista da terra, à custa de muita luta, vai mobilizando, cotidianamente, estratégias de permanência, de produção, de resistência e de desenvolvimento.

Não é por acaso que o do, inserido na denominação "do campo" bem como na designação "educação do campo" faz referência justamente ao protagonismo e êxito alcançado pelos trabalhadores e trabalhadoras que vivem e moram no campo brasileiro, que vêm conquistando seus direitos e melhorando suas condições de vida, a partir do enfrentamento aos processos de subalternidade e de negação de direitos a que foram historicamente submetidos no nosso país. "Um 'do' que não é dado, mas construído e conquistado pelo processo de formação dos sujeitos coletivos, sujeitos que lutam para tomar parte da dinâmica social, para se constituir como sujeitos políticos, capazes de influir na agenda política da sociedade" (CALDART, 2009, p. 41).

Assim, a democracia brasileira e o atual estado de pujante desenvolvimento do campo brasileiro são consequências das lutas travadas pelas populações excluídas, contra o autoritarismo do regime militar que eclodiu no final dos anos 60 e perdurou até o movimento pelas eleições diretas, em 1984. A valorização da democracia e da participação social dava o tom aos movimentos sociais da época, que reivindicavam por melhorias no sistema político, diminuição das desigualdades sociais, a garantia de direitos sociais básicos e, sobretudo, maior espaço de participação na vida política do país.

Após o golpe militar de 1964, as lutas populares no Brasil passaram a sofrer grande repressão por parte do Estado, enfrentando um longo período marcado por uma supressão violenta da liberdade individual. No primeiro ano pós-golpe, com a ascensão do Marechal Castelo Branco ao cargo de presidente, a primeira Lei de Reforma Agrária (Lei no 4504/64), o chamado Estatuto da Terra, foi decretada. Segundo o Instituto Nacional de Colonização e Reforma Agrária (INCRA), hoje vinculado ao Ministério do Desenvolvimento Agrário, a referida reforma foi pensada como "um conjunto de medidas para promover a melhor distribuição da terra mediante modificações no regime de posse e uso, a fim de atender aos 
princípios de justiça social, desenvolvimento rural sustentável e aumento de produção" ${ }^{2}$. Todavia, para o MST, a "ditadura implantou um modelo agrário mais concentrador e excludente, instalando uma modernização agrícola seletiva, que excluía a pequena agricultura $^{3 "}$.

A história fundiária do nosso país deixa claro que o Estatuto da Terra não se mostrou efetivo na distribuição de terras. As poucas desapropriações, feitas por força da Lei, serviram apenas para apaziguar conflitos pontuais de disputa de terra, ou para implementar projetos de colonização na região Norte do Brasil. Por consequência de sua não efetivação, os números de conflitos de terra se intensificaram a partir de então, culminando na necessidade de se criar outros mecanismos, independentes de mediação de conflitos de interesse fundiário. Desse modo, foi criado, em junho de 1975, a Comissão Pastoral da Terra - CPT, durante o Encontro de Pastoral da Amazônia, realizado em Goiânia (GO), convocado pela Conferência Nacional dos Bispos do Brasil (CNBB), como resposta à grave situação dos trabalhadores rurais, posseiros e peões.

Foi justamente nesse momento da história, de lutas pela terra e pela reforma agrária, com acentuada crise social e degradação humana, que nasceu o Movimento dos Trabalhadores Sem Terra - MST, resultante de uma questão agrária que é estrutural e histórica no Brasil, segundo Caldart (2000). Para a autora, o movimento é fruto da articulação das lutas sociais pela terra, que foram retomadas no cenário nacional em meados dos anos 70, especialmente na região centro-sul do país, e aos poucos se expandiram às demais regiões.

O MST foi concebido no período de 1979 a 1984, e criado oficialmente no Primeiro Encontro Nacional de Trabalhadores Sem Terra, que se realizou no período de 21 a 24 de janeiro de 1984, em Cascavel, no Estado do Paraná. Segundo dados do próprio movimento, hoje o MST está organizado em 24 estados, nas cinco regiões do país. No total, são cerca de 350 mil famílias que conquistaram a terra por meio da luta e da organização dos trabalhadores rurais (MST, 2015). "Mesmo depois de assentadas, estas famílias permanecem organizadas no MST, pois a conquista da terra é apenas o primeiro passo para a realização da Reforma Agrária" (Ibid.).

Desde sua criação, o MST segue com os mesmos objetivos definidos no Encontro de 1984, que lhe deu origem. Tais objetivos foram ratificados mais tarde, no I Congresso Nacional realizado em Curitiba, no ano de 1985: lutar pela terra, pela Reforma Agrária e pela construção de uma sociedade mais justa, sem explorados nem exploradores.

\footnotetext{
${ }^{2}$ Dados encontrados no site do INCRA. Disponível em: <http://www.incra.gov.br >

${ }^{3}$ Dados encontrados no site do MST. Disponível em: < http://www.mst.org.br/quem-somos/>
} 
Para o MST,

Ao longo de cinco séculos de latifúndio, também foram travadas lutas e resistências populares. As lutas contra a exploração e, por conseguinte, contra o cativeiro da terra, contra a expropriação, contra a expulsão e contra a exclusão, marcam a história dos trabalhadores. A resistência camponesa se manifesta em diversas ações e, nessa marcha, participa do processo de transformação da sociedade (MST, 2016) ${ }^{4}$.

Assim, a luta pela terra é retomada no Brasil na década de 80, por meio da atuação do Movimento Sem Terra e sua estratégia de ocupação como pressão política. Tais ações se configuram como eficientes instrumentos dessa luta em prol da implementação da Reforma Agrária, organizada pelos trabalhadores e trabalhadoras sem terra do nosso país, que reivindicam o direito a terra e melhores condições para sua reprodução cultural, social e econômica, para utilizarem conhecimentos, inovações e práticas sociais próprias, geradas e transmitidas pela vida em comunidade.

Quanto a sua organicidade, o MST se estrutura por meio de uma Coordenação e Direção Nacional, uma Coordenação e Direção Estadual, as Coordenações Regionais, as Brigadas, os Núcleos de Famílias e os Setores. Estes últimos estão assim organizados: Setor de Frente de Massa, de Formação, de Educação, de Produção, de Comunicação, de Projetos, de Gênero, de Direitos Humanos, de Saúde, de Finanças e de Relações Internacionais. As principais formas de luta são: ocupação de terras, acampamentos, marchas, jejuns e greves de fome, ocupações de prédios públicos, acampamentos nas cidades, acampamentos diante de bancos, vigílias e manifestações nas grandes cidades (MST, 2015) ${ }^{5}$.

Segundo Jazian Santos (2015), militante do MST na área de educação, e hoje uma das dirigentes do movimento do Sul da Bahia, foi em 1986 que o Movimento iniciou sua luta neste Estado, por consequência da vinda de militantes oriundos da região Sul do país, apoiados por lavradores locais, pelo Sindicato de Trabalhadores Rurais e por grupos de base da Igreja Católica, em especial da Pastoral da Juventude. Ao final do mesmo ano, conseguiram realizar um seminário, com a participação de mais de 120 trabalhadores rurais da região - encontro que serviu pra definir três importantes aspectos para o direcionamento da luta no Estado:

1. Reforma Agrária se faz com mobilização e que a partir daquela data se trabalharia no sentido de ocupar as terras improdutivas ou devolutas da

\footnotetext{
${ }^{4}$ In: site do MST. Disponível em: < http://www.mst.org.br/quem-somos/>

${ }^{5}$ In: site do MST. Disponível em: < http://www.mst.org.br/quem-somos/>
} 
região; 2. Era necessário um plano conjunto com os sindicatos, MST e outros movimentos populares para que a luta pela Reforma Agrária realmente fosse alcançada; 3. Havia necessidade imediata de organizar as áreas de conflito em todo o Estado (SOUZA, 2004, p.66).

A luta do MST na Bahia nasceu na Regional Extremo Sul, com as primeiras ocupações de terra, nos Municípios de Alcobaça e Prado. Em 1989 e 1990, se expandiu para a região Sul do Estado, dando origem às Regionais do Sul e Baixo Sul. Em 1995 surgiram os primeiros assentamentos no Sudoeste, e em 1996, na Chapada Diamantina. No Recôncavo, as primeiras ocupações ocorreram em 2000, e nas Regionais Oeste e Nordeste, no ano de 2006. Mais recentemente, no ano de 2015, os trabalhadores sem-terra expandiram a luta e criaram a Regional do São Francisco, por consequência da ocupação de terras no Município de Curaçá, dando origem à criação do Assentamento Fábio Santos, com mais de 180 famílias (SANTOS, 2015).

Assim, seguindo as diretrizes traçadas no primeiro encontro para a atuação do MST na Bahia, em 1987, ainda segundo Santos (2015), ocorreu a primeira ocupação de terra no Município de Alcobaça, por mais de 300 famílias sem-terra, em uma área de propriedade da empresa Floresta Nipônica Brasileira (FLONIBRA), que à época explorava a monocultura do Eucalipto, para fabricação de celulose e carvão vegetal. Surge, então, o primeiro Assentamento do MST na Bahia, nomeado como 4045, onde foram assentadas 134 famílias.

Prosseguindo sua estratégia de luta no Extremo Sul da Bahia, as famílias restantes deram início a uma segunda ocupação de terras, em 1989, no Município de Prado, formando o Assentamento Riacho das Ostras, com aproximadamente 115 famílias. Estas, segundo o Ministério do Desenvolvimento Agrário (MDA), vivem hoje da agricultura orgânica e da fruticultura, adotando o sistema de agroflorestas.

Por consequência dessa estratégia de assegurar a presença do MST em todo o Estado, atualmente o Movimento está organizado em 10 regionais: Extremo Sul, Sul, Baixo Sul, Recôncavo, Chapada Diamantina, Sudoeste, Nordeste, Oeste, Norte e São Francisco.

Segundo Santos (2015), diante do surgimento de novos desafios à luta do MST no Brasil, mas especificamente na Bahia, a partir de 2004 o Movimento sentiu a necessidade de atualizar a sua estrutura de organização. Criou-se, então, além das 10 grandes regionais, o sistema de Brigadas internas, hoje num total de 32. A Regional Extremo Sul, por exemplo, atualmente está composta por 6 brigadas: Brigada Che Guevara, Brigada Aloizio Alexandre, Brigada Joaquim Ribeiro, Brigada Olga Benário, Brigada Nelson Mandela e Brigada Elias 
Altemar Felberg - Autonomia e Desenvolvimento Comunitário NO/DO Campo: Contradições e Consensos no Assentamento Luís Inácio Lula da Silva, do Movimento sem Terra - MST - em Santa Cruz Cabrália - Bahia/Brasil

Gonçalves de Meura. Esta última, localizada na Regional do Extremo Sul, compreende os municípios de Belmonte, Santa Cruz Cabrália, Porto Seguro, Eunápolis, Itagimirim e Itapebi.

De acordo com Santos (2015), que atualmente dirige a Brigada Elias Gonçalves de Meura (EGM), a luta do MST nos municípios que compreendem a Brigada consiste no enfrentamento ao agronegócio do eucalipto, que se expandiu em toda a região, com a vinda de grandes multinacionais produtoras e exportadoras de celulose.

Segundo a militante do Movimento, a história da Brigada EGM se inicia em 2003, quando ocorreu, em 25 de março, no município de Santa Cruz Cabrália, a ocupação de uma propriedade situada às margens da BR 367, pertencente ao Sr. Ubaldino Júnior, que naquela época era prefeito da cidade de Porto Seguro. Toda a mobilização, de mais de 1.500 pessoas que participaram da ocupação, foi fruto do poder de liderança e articulação política do militante conhecido como Estrela, que conseguiu o apoio de várias associações de bairro e sindicatos da região.

Naquela época, o processo de ocupação e uso do solo no Extremo Sul era marcado por muitos conflitos entre os trabalhadores e trabalhadoras rurais sem-terra e os proprietários dos latifúndios, como bem descreve uma das lideranças do movimento na região, que também é sujeito desta pesquisa:

[...] lá era muito difícil também, porque tinha muito despejo, e essa questão da resistência, acho que ela que influenciou a gente, mais pelo fato de ver tanta vontade de adquirir a terra por parte ali dos acampados. Na época, tinha violência por parte dos proprietários das terras, que eram envolvidos com políticos também, então era muito despejo que se destruía tudo né, e a gente, acho que por conta de ver isso, mais vontade nos deu de participar, daí Guariroba também já foi na época, e a gente sofrendo, plantava, vinham, destruíam tudo, e aquilo foi nos dando mais, aguçando mais o nosso espírito de revolucionário, eu acho, de ajudar também aquelas famílias, e de fazer parte daquilo também. Foi aí que começou a nossa história (ARECA, excerto extraído do Grupo Focal no 01, realizado em maio de 2016, p. 1).

As lutas travadas no campo brasileiro são consequência do processo de invasão e colonização portuguesa, uma vez que os grandes movimentos sociais se originaram dos conflitos que se acirraram em torno da luta pelo uso e ocupação da terra e contra os processos opressores marcados pela exploração, dominação e degradação dos povos colonizados. Povos que sofreram não só as violências físicas do período colonial, a exemplo dos genocídios e escravidão, mas, sobretudo, as violências simbólicas do período pós-colonial, como a negação dos direitos sociais e trabalhistas e a discriminação étnico-racial, com reflexos ainda nos dias atuais. 
Numa história mais recente, como bem representa o relato de Areca, podemos dizer que ainda estamos num processo de aprendizagem social nesta nova era dos movimentos sociais, com cada vez mais pessoas reconhecendo e exercendo com maior naturalidade, consciência e liberdade, os princípios da democracia, participação e cidadania, salvo os processos direcionados para a representatividade, sobretudo de representação política.

À época dos conflitos retratados no relato de Areca, o MST nacional tinha definido como política e forma de luta, em todo o território nacional, a montagem de acampamentos às margens das rodovias, com o objetivo de pressionar ainda mais o governo, a efetivar a Reforma Agrária, um processo lento e burocrático, conforme destacado abaixo:

[...] Nós tínhamos na época trinta (30) famílias cadastradas, né, lá no Baianão, e era muito complicado, porque era reunião, vai pra Salvador e não tinha resultado nenhum, e a gente via as terras, enviava o documento e ficava naquele impasse, né, daí eles mandavam pessoas que vinham, faziam reunião, mas não saia daquelas reuniões, continuava nesse impasse [...] (ARECA, excerto extraído do Grupo Focal $\mathrm{n}^{\circ}$ 01, realizado em maio de 2016, p. 1)

O resultado dessa mobilização dos sem-terra no Extremo Sul da Bahia, mais precisamente no Município de Santa Crua Cabrália, resultou no Acampamento Luis Inácio Lula da Silva (Lulão), universo desta pesquisa. Tendo em vista que a área não comportava a quantidade de famílias que participaram da ação, outra mobilização de ocupação se deu em Eunápolis, por um grupo de 380 famílias, dando origem ao Acampamento Sebastião Salgado.

Quase dois anos depois, em 2004, em uma ação coordenada pela Direção Estadual, ainda segundo a diretora da Brigada EGM, os trabalhadores rurais sem-terra ocuparam uma área da empresa Veracel Celulose, no Município de Porto Seguro, intensificando ainda mais sua luta contra a monocultura do eucalipto na região. O argumento do MST é de que a multinacional de celulose expulsa o homem do campo e o impede de retirar da terra o alimento para o sustento da sua família. O fato ganhou repercussão nas mídias nacional e internacional, e reforçou sobremaneira o movimento pró Reforma Agrária na Bahia, assunto que se transformou, a partir de então, em pauta constante no Governo Estadual.

Uma das estratégias utilizadas pelo MST, para obter êxito nas empreitadas de ocupação de terras, foi esclarecer os seus integrantes, a respeito de que a ação se tratava de luta por direitos. É o que revela um dos sujeitos desta pesquisa:

[...] eu achava que o pessoal entrava numa terra era pra poder tomar do dono. Ah, porque uma dívida... Mas tinha de ver como é que ele resolvia lá com o 
governo, aí achava isso [...] eu achava aquilo ali que era uma coisa de outro mundo, né? Quando eu fui passar saber que era os nossos direitos, que é uma terra que é da União, que o povo tá atrás do direito, aí eu dei vontade de ir no acampamento [...]; não sabia que a pessoa que tinha uma terra que o governo colocava o INCRA pra avaliar, ela chegava lá e tomava a terra de qualquer jeito da pessoa, mas não era, uma parte às vezes era devoluta, outra parte o cara tava devendo, então eu não sabia disso [...] (JATAÍ, excerto extraído do Grupo Focal $n^{\circ} 01$, realizado em maio de 2016, p. 3)

Como exposto na fala de Jataí, a reivindicação dos sem-terra não é estritamente por direitos, mas pela consolidação de um novo paradigma social, onde os parâmetros de interlocução entre Estado e sociedade devem estar pautados no reconhecimento da outra parte como composta por sujeitos de direitos, como sujeitos políticos. "Esse projeto significa uma reforma moral e intelectual: um processo de aprendizagem social, de construção de novos tipos de relações sociais, que implicam, obviamente, a constituição de cidadãos como sujeitos sociais ativos" (DAGNINO, 2006, p. 57).

Mais adiante, a emissão de carta de posse de três áreas ocupadas pelo MST, no Extremo Sul da Bahia, foi o resultado de toda esta pressão política encabeçada pelos trabalhadores rurais sem-terra dos Acampamentos Lulão e Sebastião Salgado, dando origem aos Assentamentos Luís Inácio Lula da Silva, com 60 famílias, e Ojeferson Santos, com 75, ambos no município de Santa Cruz Cabrália; e por último, o Assentamento Milton Santos, com 140 famílias, no município de Porto Seguro.

A luta pela terra e contra a monocultura do eucalipto na região (enfrentamento direto às empresas VERACEL, FIBRIA e SUZANO) não parou por aí. Diversos acampamentos do MST foram montados às margens da BR 367, sob a coordenação da Brigada Elias Gonçalves de Meira: Acampamento Gildásio Sales Ribeiro, em 2008 (300 famílias); Acampamento 25 Anos, em 2009 (400 famílias); e Acampamento Irmã Dorothy, em 2011, por ação de mais de 1500 mulheres trabalhadoras sem-terra, representando um "marco na luta pela emancipação feminina, pois foi a primeira ação específica de luta das mulheres na região contra o monocultivo da celulose" (SANTOS, 2015, p. 19).

Atualmente, a Brigada Elias Gonçalves de Meura é composta por 06 áreas, 03 de Assentamentos e 03 de Acampamentos, sendo um total de 280 famílias assentadas, e 635 acampadas, com destaque, aqui, para o Assentamento Luis Inácio Lula da Silva (Lulão). 


\subsection{Assentamento Luís Inácio Lula da Silva (Lulão): a terra conquistada}

O Assentamento Luiz Inácio Lula da Silva (Lulão), antiga Fazenda Coroa Cabrália, com área total aproximada de 650 hectares, localiza-se no Município de Santa Cruz Cabrália, Costa do Descobrimento, Extremo Sul da Bahia, na altura do $\mathrm{Km} 22$, às margens da rodovia BR 367, a 46 km de Porto Seguro (BR 367), $03 \mathrm{~km}$ de Vera Cruz (BR 367) e $23 \mathrm{~km}$ de Eunápolis. Inicialmente, era conhecido como Projeto de Assentamento Coroa de Cabrália, fruto de um processo de luta do MST, que teve início em meados de 2002, a partir da chegada à região, do militante Francisco de Assis Souza, conhecido como Estrela. Naquela época, o espaço onde hoje é o Assentamento era uma área improdutiva e desabitada, com uma grande descrença em relação à conquista da terra, como descreve um dos assentados, sujeito dessa pesquisa:

Eu lembro. No início aqui era uma fazenda, uma fazenda, é... cheia de mato; eu morava aqui ao lado, na cidade de Vera Cruz, aqui perto, aí o pessoal acampou botando barraco de lona e tudo, a minha mãe mesmo foi uma delas [...] Aí eu falei assim: "Meu Deus do céu, minha mãe, a senhora tá doida, ficar nesse lugar aqui?" (++) um deserto, não tinha ninguém, o pessoal estava fazendo casa... dormindo debaixo das lonas, com medo de sumir os material (INDAIÁ, excerto extraído do Grupo Focal $n^{\circ}$ 02, realizado em maio de 2016, p. 1)

Mesmo encontrando dificuldades iniciais no processo de articulação e mobilização de famílias, para inserção na luta pela terra, na região, Estrela surpreendeu, ao reunir mais de 1.500 pessoas para a ação de ocupação de terra em área próxima ao entroncamento de Trancoso, em Porto Seguro, às margens da BR 367. Pela conjuntura política e dimensão da ação, o acampamento recebeu o nome de Luís Inácio Lula da Silva, apelidado depois de Lulão.

As famílias que hoje se encontram assentadas no Assentamento Lulão participaram e são oriundas de inúmeros acampamentos do MST, espalhados pela região do Extremo Sul da Bahia, de acordo com os relatos abaixo, expostos pelos sujeitos desta pesquisa:

[...] aí um dia passa uma pessoa em minha casa e falou: "Você não quer participar, pegar essas famílias e participar do MST?" Ia ter a ocupação do Chico Mendes (++). Aí eu falei: "Vou pensar". Depois eu falei não. Vou nada, não vou, porque é muita bagunça, muita briga, e eu não vou pegar essas famílias, né, e levar pra isso, que a gente estava tentando, naquela ilusão de que conseguiria as coisas, tudo numa boa, né? [...] eu conheci o acampamento do MST, e aí surgiu o interesse, também pelo fato de entrar no 
acampamento, ver a organização né, ver ali aquelas famílias já produzindo né, então eu resolvi ir para esse acampamento do MST, em Guaratinga, que era Itatiaia, e lá a gente começou a nossa história no movimento [...] (ARECA, excerto extraído do Grupo Focal $\mathrm{n}^{\circ}$ 01, realizado em maio de 2016, p. 1)

[...] eu fui pra lá em 1998, e aí permaneci lá até 2003, na Rosinha do Prado. Rosinha do Prado é tudo, até hoje, em qualquer canto. Foi a minha escola. Ali, conversei com eles, foi o momento que eles colocaram que o município de Porto tava montando um acampamento, que estaria surgindo um acampamento em Eunápolis, se eu poderia ajudar. Eu coloquei pra eles que eu iria pensar, mas que realmente, pra mim, era uma alegria que eu estava dentro da organização, mas não fui logo, aí foi assim que surgiu o Salgado. E aí, dali do Salgado, em 2005, nós acabamos vindo pra aqui. (ARICURI, excerto extraído do Grupo Focal no 01, realizado em maio de 2016, p. 2-3)

Quando nós chegou aqui, já tinha uma quantidade de pessoas né, já... né, de outro local, que era do Lulão, que a gente veio do Salgado, né, perto de Eunápolis, próximo a Eunápolis. Quando a gente veio pra aqui, começou a conhecer, né, esses outros barracos, né, fomos conviver com as pessoas que a gente não conhecia ainda. (BABAÇU, excerto extraído do Grupo Focal $n^{\circ}$ 02 , realizado em maio de 2016, p. 1)

Os três depoimentos demonstram características peculiares dos sujeitos sem-terra: primeiro, de serem forjados e formados no movimento, na luta pela terra, por direitos e por melhores condições de vida; segundo, pelo aparente sentimento de pertencimento a um grupo social; e terceiro, pela solidariedade e coesão social demonstrada nos processos de construção e desenvolvimento dos acampamentos sem-terra.

Em abril de 2004, a ocupação foi estendida às terras da Veracel Celulose S.A, que ficavam ao lado do acampamento Lulão, ação que forçou o Governo Federal a negociar três áreas para assentar as famílias: Fazenda Serro Azul, situada no Município de Porto Seguro, hoje Assentamento Milton Santos; Fazenda Bela Vista Movelar, situada no Município de Cabrália, hoje Assentamento Ojeferson Santos; e a Fazenda Coroa de Cabrália, situada no Município de Santa Cruz Cabrália, hoje Assentamento Luís Inácio Lula da Silva.

Fato histórico e de muito orgulho para os sem-terra do Acampamento Lulão ocorreu no dia 20 de janeiro de 2005, quando o então Presidente da República, Luis Inácio Lula da Silva, visitou o acampamento e reafirmou a luta do seu governo para a consolidação da Reforma Agrária no país, comprometendo-se com as famílias presentes a assentar todas elas ainda naquele ano, e participar da entrega oficial da emissão de posse das áreas.

Conforme o prometido, em 22 de setembro de 2005 chegou a notícia, pelas mãos de dirigentes do INCRA, do Governo do Estado da Bahia e de líderes do MST, que as terras 
Altemar Felberg - Autonomia e Desenvolvimento Comunitário NO/DO Campo: Contradições e Consensos no Assentamento Luís Inácio Lula da Silva, do Movimento sem Terra - MST - em Santa Cruz Cabrália - Bahia/Brasil

reivindicadas pelas famílias estavam liberadas para o processo de Assentamento, o que foi motivo de grande comemoração e alegria, segundo relata Santos (2015).

Assim, imediatamente à confirmação da tão esperada notícia, as famílias seguiram para as três áreas recentemente conquistadas, dando origem aos Assentamentos Milton Santos, Ojeferson Santos e Luís Inácio Lula da Silva. Esse acontecimento é narrado por Macaúba, sujeito desta pesquisa:

[...] aí depois foi quando saiu pra cada um o pedaço de terra, aí cada um foi mudando pros seus lugares, só que ainda não era o local certo, aí minha mãe ficou logo em uma terrinha aqui próxima, e aí nós ia pra lá, e aí todo mundo ficou mudando. Uns ficou aqui, outros foram mudando pras terrinhas, aí depois que teve o local certo, que dividiu os lotes e cada um foi pros seus lotes, aí cada um foi se virar e fazer o seu. (MACAÚBA, excerto extraído do Grupo Focal n ${ }^{\circ}$ 02, realizado em maio de 2016, p. 1)

Depois de devidamente assentadas, com moradias em regime de Agrovilas, lotes individuais e áreas coletivas de produção, o então Presidente Luís Inácio Lula da Silva reúnese, no dia 27 de setembro de 2005, com todas as famílias, para entregar oficialmente a imissão de posse das áreas. O presidente abre seu discurso, dizendo:

Eu queria chamar aqui o seu Tertuliano, se ele pode ficar aqui do lado, porque eu acho que a nossa querida Anita Maria de Jesus e o nosso querido Tertuliano Dias Nascimento, ela com 64 anos de idade, e ele com 82 anos de idade, são a mais viva demonstração... E eu vou repetir uma coisa que eu dizia em 89, em 94, em 98, e não posso mudar o meu discurso porque eu virei Presidente da República. Eu sempre achei que a grande coisa, ou uma das grandes coisas que o Movimento Sem-Terra faz, pelo Brasil, é que o Movimento Sem-Terra é capaz de tirar pessoas que estão quase virando párias da sociedade, espalhadas por esse mundo, sem esperança, e transformá-las em guerreiros e guerreiras, como ele fez com a Dona Anita ou com o senhor Tertuliano: dar esperança, perspectiva, mostrar um horizonte para as pessoas, o que só acontecerá com muita perseverança e com muita luta (BRASIL, 2005, p.1-2).

Em seu discurso, o presidente fala da árdua luta dos trabalhadores e trabalhadoras rurais sem-terra, e reconhece a importante contribuição do MST para a construção de um país mais justo, fraterno e humano, com igualdade de oportunidades a todo brasileiro.

No que diz respeito à infraestrutura do Assentamento, o que, de certa forma, traça um marco zero dos indicadores de desenvolvimento da comunidade (situação em 2005), cujo levantamento também faz parte dos objetivos específicos deste trabalho, o então Presidente 
Altemar Felberg - Autonomia e Desenvolvimento Comunitário NO/DO Campo: Contradições e Consensos no Assentamento Luís Inácio Lula da Silva, do Movimento sem Terra - MST - em Santa Cruz Cabrália - Bahia/Brasil

Lula retrata em seu discurso o cenário que encontrou em sua visita, vislumbrando inúmeras possibilidades de desenvolvimento do local:

[...] Certamente alguém vai dizer: 'mas o presidente Lula foi num assentamento que não tem TV a cabo, o presidente Lula foi num assentamento que não tem telefone celular, o presidente Lula foi num assentamento em que ainda não tem a casa com uma varanda e com uma rede pendurada para a gente se espreguiçar'. Nem podia ter. O que é importante é medir a qualidade desse assentamento, aqui. Eu estou daqui só olhando os carros passando ali numa estrada asfaltada. Portanto, não vai ter problema de escoamento da produção. Eu sei que nesta região tem água. Estou vendo postes, ali, que leva luz para tudo quanto é lugar. Pois bem, o Programa Luz para Todos vai iluminar a casa de cada companheiro assentado, não apenas neste assentamento. O nosso compromisso é assentar todas as casas que não têm luz até 2008 (BRASIL, 2005, p.2).

A descrição da área, pelo então presidente, foi bem precisa, o que pode ser confirmado nos relatos abaixo:

[...] aí, quando a gente veio pra cá, a gente, né, foi construir casas, né, porque a gente não tinha casas de lona [...] foi é... cavar poços, poço não, como é que se fala, cisternas nesse local, pra todo mundo, né, começar já a ter uma água pra beber, porque quando logo nós chegou, não tinha, né? (BABAÇU, excerto extraído do Grupo Focal $\mathrm{n}^{\circ}$ 02, realizado em maio de 2016, p. 1).

[...] aí fez uma escolinha de lona, eu mesmo lembro até hoje a professorinha dando aula em uma salinha, aquele tanto de criancinhas, e ela dando aula, nem era professora de verdade, era uma professora só pra poder ensinar as crianças a saber ler e escrever, né? (MACAÚBA, excerto extraído do Grupo Focal $\mathrm{n}^{\circ}$ 02, realizado em maio de 2016, p.1).

Fica evidente, nos relatos, que o Assentamento Lulão não possuía qualquer infraestrutura comunitária preexistente. Contudo, tinha grande potencial de desenvolvimento, especialmente por localizar-se à margem da BR-367.

Considerando o potencial de desenvolvimento da terra conquistada, a aprendizagem social oportunizada por meio da participação no MST e a luta e esforço dos sem-terra no Assentamento Lulão, dez (10) anos depois da sua criação, é que tratamos de compreender, nesta pesquisa, de que modo os indicadores de desenvolvimento comunitário rural desse assentamento refletem o grau de autonomia de seus moradores e qual o papel da educação no processo de formação de sujeitos autônomos. 


\subsection{Autonomia: uma condição do sujeito de "ser para si"}

Etimologicamente, autonomia vem do grego autós (ele mesmo, por si mesmo) e nomos (lei, convenção, regra), que significa o poder de dar a si a própria lei. Importa destacar, aqui, que este governo sobre si mesmo não pode ser entendido com um poder inato à condição humana, absoluto e ilimitado, nem mesmo pode ser confundido pura e simplesmente com os conceitos de autossuficiência e liberdade, mesmo que estes estejam intrínsecos à noção de autonomia e indissociabilidade. Também podemos entender a autonomia como "condição de uma pessoa ou de uma coletividade cultural, que determina ela mesma a lei à qual se submete" (LALANDE, 1999, p. 115).

A autonomia é a posição do sujeito sócio-histórico-cultural que, por sua própria ação e vontade ética, é criador das leis e regras da sua existência social e política, o que na perspectiva freiriana tem a ver com o 'ser para si'. Num contexto histórico subdesenvolvido dos oprimidos, a autonomia está intimamente relacionada com a libertação, conforme Chauí (1990). Ela conduz diretamente ao problema político e social da humanidade, posto que não se pode almejá-la, sem desejá-la a todos, sua realização plena é fruto de empreitada coletiva. Esse entendimento é também defendido por Freire (1986), quando este nos alerta que, mesmo quando nos sentimos mais livres, mais autônomos, se esta conquista não for utilizada a favor da coletividade, estaremos apenas exercitando uma autonomia individualista, no sentido do empoderamento pessoal.

É justamente nessa perspectiva que se firmou esta pesquisa, inicialmente buscando responder às seguintes questões: Como se configura o exercício da autonomia dos homens e mulheres assentados/a no Assentamento Luis Inácio Lula da Silva, dez anos após a posse da terra? O que pensam esses sujeitos sobre o seu agir, sobre o seu pensar, sobre a vida em comunidade, sobre o envolvimento com o MST?

A nossa preocupação inicial é verificar se a autonomia, como defende Pereira (2007), é reconhecida como um recurso capaz de livrar os indivíduos não só da heteronomia de processos opressores sobre as suas liberdades de escolha e de ação, mas também da miséria e do desamparo, da privação do exercício de um dos direitos sociais mais sagrados: a participação ativa e qualificada nos processos de discussão, formulação e usufruto efetivos das políticas de desenvolvimento.

O conceito de autonomia se apresentou na literatura acadêmica, basicamente vinculado à ideia de participação social e de ampliação da participação e voz de 
representantes das classes historicamente subalternizadas nos espaços de discussão política, visando, essencialmente, a descentralização do poder e a construção de um novo modelo de sociedade, que contemplasse, dentre outros aspectos, a ampliação das bases que sustentam a atual democracia e uma ampla transformação econômica, política e social.

Historicamente, o debate sobre as transformações das sociedades democráticas e de seus mecanismos de funcionamento resvala do tema da participação social e política de indivíduos, para a complexidade que envolve a questão da distribuição e desconcentração do poder nessas sociedades, isto é, a representação. Não é a toa que durante os séculos XVII e XVIII, a distinção entre representação e participação sempre esteve presente na base das discussões das teorias políticas da época, sendo pauta de discussões ainda nos dias atuais.

Segundo Martins (2001), esse conjunto de mudanças, na concepção e estrutura da sociedade, objetivava - atendendo ao desiderato inicialmente utópico dos pensadores liberais da época - instaurar um modelo de desenvolvimento que implicasse a liberdade dos sujeitos e a garantia dos direitos constitutivos da cidadania, de forma justa e igualitária. Todavia, para Boaventura de Sousa Santos (2005), infelizmente o princípio da cidadania se resumiu a uma cidadania civil e política, com o desencorajamento evidente, por parte dos governos, de quaisquer outras formas de participação política. Dessa forma, para o autor, "a representação democrática assenta na distância, na diferenciação e mesmo na opacidade entre representante e representado" (SANTOS, 2005, p. 238).

Embora seja imprescindível a interpretação do fenômeno a partir dos acontecimentos histórico-políticos que deram início ao surgimento dos primeiros movimentos autogestionários e de luta pelo desenvolvimento, expansão das liberdades individual e social e exercício da autonomia, bem como a partir das ideias dos principais teóricos que influenciaram a supressão da exploração do homem pelo homem, ${ }^{6}$ concentrar-nos-emos, neste momento, na busca do significado da palavra autonomia, na perspectiva da semântica, da filosofia e da antropologia iluminista, buscando, primeiramente, compreender sua dimensão moral, entender como ela se processa no campo da razão.

Apesar de o conceito de autonomia somente ter sido claramente definido e ganhado força e destaque na modernidade, especialmente com Kant (1974), na Grécia Antiga já surgiam os primeiros pensamentos concebendo sua noção.

Conforme Bourricaud (1985), os historiadores gregos, em especial Tucídides e Xenofonte, citam povos que se rebelavam e buscavam sua independência, o que já desponta,

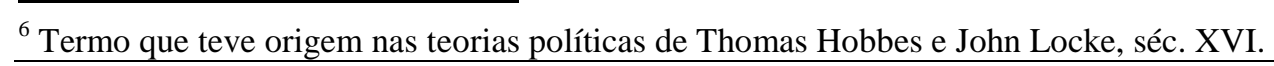


há cerca de 400 anos a.C., a ideia de autodeterminação política da Polis, entendida como a comunidade organizada, formada pelos cidadãos, assunto que foi retomado no século XI, por Thomas Hobbes (1588-1679), e consolidado no bojo da ciência política. Obviamente que a noção de autonomia dos historiadores gregos ficou restrita à corrente de pensamento teórico das relações políticas e de autodeterminação das cidades. É aproximada do conceito de autarcia $^{7}$, de suficiência, de não ter necessidade de ninguém (BOURRICAUD, 1985).

Ainda na Grécia antiga, Platão (428/427 a.C. - 347 a.C.) dá mais um passo na construção do atual conceito de autonomia, concebendo uma noção um pouco mais elaborada sobre o fenômeno, indo além da ideia de autodeterminação política das cidades. Naquela época, a noção de autonomia ainda não possuía caráter moral - o que só apareceu mais adiante, no pensamento aristotélico - mas Platão, indiretamente, contribuiu para o desenvolvimento do conceito moderno de autonomia nesse aspecto, uma vez ter pensado o autodomínio. Somos bons quando a razão governa, e maus quando dominados por nossos desejos, conforme Taylor (1997).

Platão distingue as partes superiores e inferiores da alma, afirmando que dominar a si mesmo é fazer com que a parte superior da alma controle a inferior, ou seja, fazer com que a razão controle os desejos. Assim, ser governado pela razão, ser racional, é ser senhor de si mesmo, pensamento que inclui claramente a ideia de autonomia.

Para o mais genuíno discípulo de Platão, Aristóteles (384/383 a.C. - 322 a.C.), a noção de autonomia recebe uma dimensão moral e ética, conforme Zatti (2007). O pensamento ético de Aristóteles, no percurso existencial de compreender a essência do ser humano, para além da razão, contribuiu de forma significativa para o desenvolvimento do conceito de autonomia. Para o filósofo grego, o homem cidadão é conduzido por um conjunto de conceitos e valores que o levam, por meio da análise racional, a entender melhor o mundo que o cerca e o seu lugar no universo.

A partir dessa concepção, o homem é capaz de se distinguir e de distinguir o certo do errado, e a optar entre o bem e o mal, atingindo, assim, o ápice da realização humana, que é a felicidade plena. Esta capacidade do homem, de discernir entre o que é aceitável socialmente e o que é ilícito diante de Deus e dos homens foi fundamental nas antigas civilizações, e ainda o é, na atualidade, no que se refere ao processo de emancipação e legitimação do homem. O Bem se basta por si mesmo, é o seu próprio fim, é livre de toda necessidade. Assim, a

\footnotetext{
${ }^{7}$ A condição de autossuficiência do sábio, para quem ser virtuoso basta para ser feliz, segundo os cínicos (DIÓG. L, VII, 11) e os estóicos (Md., VII, 1, 65). Fonte: ABBAGANO (2007, p. 95).
} 
Altemar Felberg - Autonomia e Desenvolvimento Comunitário NO/DO Campo: Contradições e Consensos no Assentamento Luís Inácio Lula da Silva, do Movimento sem Terra - MST - em Santa Cruz Cabrália - Bahia/Brasil

felicidade e a autonomia se dão ao sujeito que possui tal Bem (felicidade), de acordo Bourricaud (1985).

Posteriormente, também os estóicos ${ }^{8}$, embora na época ainda não lançassem mão do termo 'autonomia', contribuíram para a evolução do conceito, agregando a ideia de independência a toda regulação e todo constrangimento externo, e a satisfação das próprias necessidades, sem que a cidade ou o indivíduo precise estar em dependência de outro.

Segundo Abbagnano (1962), para os estóicos há uma Razão Divina (Natureza) que rege o mundo, segundo uma ordem necessária e perfeita. Da mesma forma que o animal é guiado pelo instinto, o homem é guiado infalivelmente pela razão. Neste sentido, a doutrina filosófica dos estóicos se centrava na ideia de que, pelo conhecimento de uma regulação divina, natural, o homem tinha livre arbítrio e independência. A autonomia do sujeito se situa ao nível de julgamento, que compreende a capacidade de prever e escolher, conforme Bourricaud (1985).

Partindo desse princípio, o indivíduo tinha, então, liberdade para se autogovernar e traçar seu próprio caminho e filosofia de vida, a partir da obediência a uma razão superior e alheia à interferência terrena. Foi neste aspecto, o da assunção do sentimento de liberdade e obediência à razão, a maior contribuição desta doutrina filosófica para a noção de autonomia, mesmo numa época ainda distante do conceito como hoje é entendido.

No desenrolar da história, naturalmente, essa ideia foi adquirindo novos e diferentes significados. E assim, à medida que foram lançados novos olhares ao fenômeno, o conceito foi tomando outras dimensões. Por isso, para poder utilizar, de forma precisa, a definição de autonomia de determinado autor, a uma situação específica, deve-se, primeiramente, verificar a qual heteronomia este autor se opôs, na construção de sua noção de autonomia, e a qual contexto histórico e teórico tal noção se insere.

Para melhor entendimento do conceito de autonomia, não poderíamos deixar de também abordar um aspecto ligado ao princípio da conexão universal referente ao materialismo dialético, que é o da heteronomia. Heteronomia é a sua concepção antagônica, contrária. Esta, em linhas gerais, conforme Chauí (2000), é toda lei que procede de outro,

\footnotetext{
${ }^{8}$ ESTOICISMO. Uma das grandes escolas filosóficas do período helenista, assim chamada pelo pórtico pintado (Stoá poikílé) onde foi fundada, por volta de 300 a.C, por Zenão de Cício. Os principais mestres dessa escola foram, além de Zenão, Cleante de Axo e Crisipo de Soles. Com as escolas da mesma época, epicurismo e ceticismo, o Estoicismo compartilhou a afirmação do primado da questão moral sobre as teorias e o conceito de filosofia como vida contemplativa acima das ocupações, das preocupações e das emoções da vida comum. Seu ideal, portanto, é de ataraxia ou apatia (v.). (ABBAGANO 2007, p. 375).
} 
Altemar Felberg - Autonomia e Desenvolvimento Comunitário NO/DO Campo: Contradições e Consensos no Assentamento Luís Inácio Lula da Silva, do Movimento sem Terra - MST - em Santa Cruz Cabrália - Bahia/Brasil

hetero (outro) e nomos (lei, norma, regra), é receber, de outro, a lei, a norma ou a regra que o controlam, o governam. Heteronomia é a "condição de uma pessoa ou de uma coletividade que recebe do exterior a lei à qual se submete" (LALANDE, 1999, p. 115).

Nesta perspectiva, situações como opressão, censura, repressão ou outras situações características de governos ditatoriais, assim como o acesso restrito às oportunidades sociais e liberdades políticas, por exemplo, impõem determinações que limitam ou impedem o exercício da autonomia, sendo caracterizadas, portanto, como heteronomia.

Segundo Zatti (2007), Nicolau Maquiavel (1469-1527) foi o primeiro pensador da modernidade a desenvolver um conceito de autonomia política, a partir do empirismo e da análise dos fatos que marcaram a cena política na Roma Antiga. Desta forma, com a obra Discursos, foi o pioneiro na área, apresentando um conceito de autonomia que se fundava na liberdade de dependência e no poder do Estado de se autolegislar (CAYGILL, 2000).

Na mesma época, quebrando paradigmas e desafiando o poder da Igreja Católica e de seu sumo sacerdote (o Papa Leão X), o padre e professor alemão, Martinho Lutero (14831546), foi outro grande precursor do conceito de autonomia, ao contestar a venda de indulgências e a supremacia da Igreja. Ele defendia a ideia de que a impunidade pelos pecados cometidos não poderia ser comprada, e que cada um teria sua liberdade espiritual em relação ao corpo e seus desvios de comportamento. Assim, o sujeito seria autônomo na medida em que estivesse livre das inclinações do corpo e obedecesse à Lei Divina, sem interferência dos sacerdotes (CAYGILL, 2000).

Nesta perspectiva, podemos inferir que as contribuições de Martinho Lutero à noção de autonomia resumem-se na salvação, como livre presente de Deus, na liberdade de acesso às santas escrituras e na assunção de todo cristão como sacerdote nato, desqualificando o autoritarismo sacerdotal.

Já os iluministas ${ }^{9}$ apresentaram uma noção de autonomia que é contrária à “Escolástica, à religião, à tradição, ao Antigo Regime”, ou seja:

A noção de autonomia dos iluministas deriva de sua concepção antropológica e pressupõe a imanência, a historicidade, o materialismo, a atividade do homem, que por meio do poder quase irrestrito das ciências, suplanta os mitos, as superstições, medos, opressões, imoralidades, e assim

\footnotetext{
${ }^{9}$ Kant define o Esclarecimento [Aufklärung], termo usado para o Iluminismo, como: a saída do homem de sua menoridade, da qual ele próprio é culpado. A menoridade é a incapacidade de fazer uso de seu entendimento sem a direção de outro indivíduo. "O homem é o próprio culpado dessa menoridade, se a causa dela não se encontra na falta de entendimento, mas na falta de decisão e coragem de servir-se de si mesmo sem a direção de outrem. Sapere aude! Tem coragem de fazer uso de teu próprio entendimento, tal é o lema do esclarecimento [Aufklärung]" (KANT, 2005, p. 63-64).
}

Universidade Lusófona de Humanidades e Tecnologias -FCSEA- Instituto de Educação 
se constrói rumo a um progresso certo em todos os campos de sua vida, garantido pela positividade, pela exatidão das ciências. Ainda, é um homem que encontra a autonomia na vivência dos próprios desejos. Caberia à educação formar esse homem 'esclarecido', 'autônomo' (ZATTI, 2007, p. 25).

Consolidando todas as contribuições filosóficas e práticas à noção de autonomia até aqui apresentadas, ora corroborando algumas ideias, ora lançando novas reflexões, surge Immanuel Kant (1724-1804), que provavelmente tenha sido, segundo estudiosos sobre o assunto, o mais notável e conhecido pensador da modernidade, por ter lançado a teoria do imperativo categórico, a qual trata de uma obrigação moral única e geral que explica todas as outras obrigações morais do indivíduo. Em seu sentido moderno de autonomia, eleva a razão e a vontade como pilares da dignidade humana. Dessa forma, é na modernidade, com Kant, que o "problema da autonomia ganha força e centralidade" (ZATTI, 2007, p. 17).

É consenso, entre pesquisadores, que Kant foi o primeiro teórico a se ater ao estudo e definição do conceito de autonomia na modernidade, trazida em sua principal obra, Fundamentação da Metafísica dos Costumes (1785), que traz o princípio da autonomia como imperativo categórico, cuja formulação geral, nas próprias palavras de Kant, é: “Age apenas segundo uma máxima tal que possas ao mesmo tempo querer que ela se torne lei universal" (KANT, 1974, p. 223).

A essência do imperativo categórico de Kant sugere que a autonomia é "a ideia da vontade de todo ser racional concebida como vontade legisladora universal” (KANT, 1974, p. 231). No decorrer da sua obra, constantemente é utilizada a expressão genérica 'princípio autônomo', no sentido de que o “princípio tenha em si, ou coloque por si mesmo, a sua validez ou a regra de sua ação" (ABBAGNANO, 1962, p. 93).

Assim, percebe-se que, em seu percurso reflexivo, Kant considerou a totalidade do sujeito, ampliando a função restrita da razão como instrumento cognitivo, elevando-a a um sentido mais amplo, e poder prático para alcançar o que se deseja. Nesse sentido, a razão ganha status de poder hegemônico, na condução do indivíduo à dignidade humana.

$\mathrm{Na}$ abordagem kantiana, a vontade humana é a materialização objetiva do que a razão faculta, independentemente de inclinações e isenta de quaisquer interesses. Para ele, o indivíduo decreta suas próprias leis rumo à realização daquilo que julga bom e necessário. Dessa forma, Kant considera a autonomia da vontade o "princípio supremo da moralidade" (KANT, 1974, p. 238). 
Na interpretação de Zatti (2007, p. 19-20), “o ser racional, ao participar da legislação universal, ao se submeter à lei que ele próprio se confere, é fim em si, não possui valor relativo, mas uma dignidade, um valor intrínseco". Essa afirmação corrobora o pensamento kantiano, de que "a autonomia é, pois, o fundamento da dignidade da natureza humana e de toda a natureza racional" (KANT, 1974, p. 235).

Do ponto de vista kantiano, sobre autonomia, a natureza advinda da razão finda em si mesma. Desta forma, todo o ser pensante, racional, possui dignidade particular, independente. Diferentemente dos demais seres da natureza, é considerado livre e autodeterminante. Dessa forma, para Kant, a pessoa dotada de liberdade, sem intervenção alheia, torna-se autônoma à medida que utiliza a liberdade com maior clareza e consciência, em suas atitudes na sociedade.

Diversos outros autores contemporâneos se debruçaram sobre a temática da autonomia, com destaque aqui para Castoriadis (1991), Adorno (1984), Paulo Freire (1986), Marilena Chauí (1990), Bobbio (2000) e Amartya Sen (2008), cujas discussões suscitaram novos enfoques e entendimentos. No conjunto de suas obras, é possível perceber que a autonomia não é inata ao ser humano, não se dá apenas na consciência dos sujeitos, mas na dinâmica como o mundo evolui, como o sujeito o enxerga e se posiciona livremente diante dele. Trata-se de uma condição a ser conquistada individualmente, pela independência da vontade a um determinado objeto de desejo e pela liberdade de ação. E configura-se como a capacidade do indivíduo governar-se conforme uma lei própria, de maneira livre e racional, conduzindo-se à dignidade humana.

Para os referidos autores, ter mais autonomia e agir com maior liberdade de pensamento e ação melhora o potencial das pessoas para cuidar de si mesmas e para influenciar o mundo - questões centrais para o processo de desenvolvimento. Refletindo sobre tais questões, nos interrogamos como conquistar ou potencializar essa autonomia. E pensando nos sujeitos do campo, nos questionamos acerca do contributo da Educação para essa conquista, se ela tem desenvolvido a capacidade de se assumirem enquanto sujeitos de direitos e protagonistas de suas próprias histórias de desenvolvimento, pessoal e coletivo.

\subsection{Educação do Campo: a luta por uma educação diferenciada}

Partimos do pressuposto de que o investimento no atendimento às necessidades humanas básicas, particularmente na área da educação, melhora a produtividade e o 
crescimento econômico rumo à instauração de um modelo de desenvolvimento ético, que implique a garantia de direitos constitutivos da cidadania.

Em uma breve retrovisão histórica, podemos afirmar que a luta dos movimentos sociais e dos educadores e educadoras do campo, pelo direito à educação, assim como pela reforma agrária, advém de muitos séculos passados. Vale destacar que o direito à educação vem sendo historicamente negado e usurpado à população brasileira do campo, com raízes que remontam o processo de colonização da nação brasileira, como salienta Batista (2011, p. 54-55):

As lutas no campo brasileiro têm início com o processo de invasão e colonização portuguesa. Os movimentos se originam dos conflitos em torno da luta por terra, mas também se rebelam contra as relações sociais de produção marcadas pela exploração, pela dominação e degradação da pessoa humana, como a escravidão, contra a negação da cidadania, pelos direitos sociais e trabalhistas, pelo reconhecimento das diferentes culturas. Essas múltiplas demandas envolveram diferentes sujeitos, índios, negros, caboclos, agricultores, escravos, ferreiros, barqueiros. O que denota que a resistência dos povos oprimidos e despossuídos esteve presente ao longo da história brasileira, nos períodos colonial, monárquico e republicano e é um dos elementos da identidade política do povo.

Nos séculos seguintes à colonização, até meados do início do século XIX, ainda segundo a autora, é fato que diversas mudanças socioeconômicas e culturais ocorreram sobretudo por força dos processos de resistência - sem, contudo, provocarem transformações sociais efetivas e duradouras, especialmente no campo da educação, prevalecendo o método pedagógico jesuítico do período colonial, que se estendeu de 1549 a 1759, ressoando nas décadas seguintes, até a independência. Com esta ruptura, daí em diante, algumas iniciativas relativas à educação foram efetivadas, a exemplo da "criação das Academias Militares, Escolas de Direito e Medicina, a Biblioteca Real e o Jardim Botânico" (BATISTA, 2011, 56). Apesar dos avanços na área, ainda não se tinha um sistema educacional de âmbito nacional, o que só se concretizou no século XX, a partir da década de 30.

Voltando à história da educação do campo, os militantes e profissionais que lutam por uma educação diferenciada do campo questionam que, apesar dos movimentos docente e pedagógico progressista do Brasil buscarem o reconhecimento da educação como um direito humano, desde a década de 80 , as conquistas alcançadas pelo movimento não geraram os frutos esperados, no campo. Argumentam que o direito à educação, então conquistado pelo movimento progressista, "ficou vinculado a uma concepção abstrata de cidadania, não traduzindo a concretude humana e social em que os direitos se tornam realidade" (ARROYO et al., 2004, p. 10). 
Diante desse contexto, fica claro que a Educação do campo nasceu, essencialmente, como crítica à realidade do sistema educacional no Brasil, particularmente à situação educacional da população brasileira que trabalha e vive no/do campo. Uma crítica não apenas à educação, mas ao modelo de sistema econômico capitalista e sua injusta distribuição de renda; ao incentivo ao agronegócio e à expropriação de terras tradicionais; à elitização do acesso à ciência, à tecnologia, à cultura e às suas produções; enfím, críticas a não universalização de direitos que garantem a plena cidadania (CALDART, 2009).

Desta forma, esta crítica, ainda na visão da autora, não foi voltada exclusivamente à educação escolar em si, mas como essa educação estava desalinhada à realidade educacional do país, que não considerava a especificidade dos processos sociais, políticos e culturais pujantes do campo, processos estes que extrapolavam sobremaneira as discussões para além de uma educação linear, cartesiana e formadora de indivíduos na ótica do capitalismo. E ainda, como essa educação desconsiderava a totalidade do sujeito, sua natureza e condição de agente sócio-histórico-cultural. "Ou seja, precisamos considerar na análise que há uma perspectiva de totalidade na constituição originária da Educação do campo" (CALDART, 2009, p. 38).

Ampliando essa análise, vale destacar que esta crítica não se deu no campo da epistemologia da educação (ainda que isso ocorresse naturalmente, por consequência do processo). Pelo contrário, ela foi fundamentada numa 'crítica prática', forjada no calor das reivindicações dos movimentos sociais, que lutavam pelo direito à educação, a partir da "realidade da luta pela terra, pelo trabalho, pela igualdade social, por condições de uma vida digna de seres humanos no lugar em que ela aconteça" (Ibid. p. 39).

Uma crítica prática que se fez teórica ou se constituiu também como confronto de ideias, de concepções, quando pelo 'batismo' (nome) assumiu o contraponto: Educação do campo não é Educação rural, com todas as implicações e desdobramentos disso em relação a paradigmas que não dizem respeito e nem se definem somente no âmbito da educação. (CALDART, 2009, p. 40).

Os grandes protagonistas do processo de criação da Educação do campo e seu aperfeiçoamento foram os movimentos sociais camponeses em estado de luta, com destaque para os movimentos sociais de luta pela reforma agrária, particularmente para o Movimento dos Trabalhadores Rurais Sem Terra (MST). Todavia, no decorrer da luta outros movimentos sociais em defesa do povo campesino foram surgindo e aderindo à causa, por uma educação do campo, consolidando-a como hoje a conhecemos. Esses movimentos são os seguintes: o 
Movimento dos Atingidos por Barragens (MAB), o Movimento das Mulheres Camponesas (MMC), o Movimento dos Pequenos Agricultores (MPA), a Pastoral da Juventude Rural (PJR), a Comissão Pastoral da Terra (CPT) e a Federação dos Estudantes de Agronomia (FEAB). Somaram-se às iniciativas o movimento sindical do campo, especialmente aqueles vinculados à Confederação Nacional dos Trabalhadores da Agricultura (CONTAG) e a Federação dos Trabalhadores da Agricultura Familiar (FETRAF). Assim:

O vínculo de origem da Educação do campo é com os trabalhadores 'pobres do campo', trabalhadores sem-terra, sem trabalho, mas primeiro com aqueles já dispostos a reagir, a lutar, a se organizar contra 'o estado da coisa', para aos poucos buscar ampliar o olhar para o conjunto dos trabalhadores do campo (CALDART, 2009, p. 41).

Para a autora, talvez seja essa a marca histórica mais incômoda e fascinante da Educação do campo, no contexto sócio-histórico-político-econômico e cultural do país: o protagonismo e a autonomia dos sujeitos que vivem do/no campo, "os sujeitos que se põem em cena como construtores de uma política de educação e de uma reflexão pedagógica". (Ibid.). Graças a estes precursores da luta "por uma educação do campo”, é que, hoje,

Milhares de educadores e educadoras se mobilizam, se reúnem, debatem, estudam e refazem concepções e práticas educativas em escolas de comunidade camponesas, em escolas-família agrícola, em escolas dos reassentamentos do Movimento dos Atingidos pelas Barragens, em escolas de assentamentos e de acampamentos do Movimento dos Sem Terra, ou em escolas de comunidades indígenas e quilombolas (ARROYO et. al., 2004, p. 09).

Indo ao encontro dessas discussões de Arroyo, Caldart (2009, p. 40) afirma que a Educação do campo não pode ser compreendida tomando unicamente por base os parâmetros teóricos da pedagogia. Ela extrapola o campo da ciência da educação e provoca reflexões em várias outras áreas, como a política, a sociologia e a economia, gerando discussões no intuito de romper velhos paradigmas e propor novos caminhos para um desenvolvimento mais ético, justo e igualitário, por isso é um "movimento real de combate ao 'atual estado de coisas"”.

Enfim, é pelo seu poder de provocar mudanças e reflexões em outros campos da ciência, oportunizando aos sujeitos condições para expandir suas capacidades de reflexão e ação, assumindo seus papéis sócio-histórico-culturais, que a educação do campo se apresenta nesta pesquisa, com o papel de potencializar o processo de conquista da autonomia, melhorando o potencial das pessoas para cuidar de si mesmas e influenciar o mundo, rumo a 
um modelo de desenvolvimento justo e inclusivo. Este, a partir da modernidade, segundo Sen (2008), suscita novos enfoques para além do crescimento econômico, incluindo aspectos avaliativos, como acesso a oportunidades sociais e expansão das capacidades individuais, liberdades políticas e também facilidades econômicas. E na construção desse modelo, podemos nos perguntar: Quais contribuições podem ser atribuídas à Educação nesse processo de empoderamento, combate à pobreza e desenvolvimento integral e integrado das comunidades do/no campo brasileiro? E ainda, qual a efetividade do desenvolvimento sustentável em territórios rurais, com o oferecimento de uma educação do campo baseada em valores humanistas, como solidariedade, participação e justiça social?

\subsection{Desenvolvimento e Desenvolvimento Rural: conceitos e delimitações}

Há várias visões e abordagens em torno do conceito de desenvolvimento e seus significados, cada um atendendo a uma época da História, conforme destaca Favareto (2006). A mais conhecida e talvez a mais difundida seja a utilização do conceito de crescimento como sinônimo de desenvolvimento. Numa perspectiva econômica, os dois termos fundiam-se; o último como resultado do primeiro, conforme o autor.

Além da dimensão do crescimento econômico, existe a dimensão social e ambiental, com pouco ou nenhum diálogo entre si, que aqui não serão tratadas individualmente, em virtude da natureza e sentido que se quer dar a este trabalho. Interessa, aqui, especificadamente, trazer o conceito de desenvolvimento em seu sentido mais amplo, geral, o que, neste caso, acompanha o próprio desenvolvimento da humanidade e sua evolução ao longo dos tempos; em seguida, discorrer sobre o desenvolvimento no mundo rural, trazendo-o a partir de uma abordagem comunitária e territorial - o que se deseja.

De acordo Abbagnano (2007, p. 241), desenvolvimento pode ser definido como:

Movimento em direção ao melhor. Embora essa noção tenha precedentes no conceito aristotélico de movimento (v.) como passagem da potência ao ato ou explicação do que está implícito (CÍCERO, Top., 9), seu significado otimista é peculiar à filosofia do séc. XIX e está estreitamente ligado ao conceito de progresso (v.).

Ainda segundo Favareto (2006), para falar em desenvolvimento é preciso aludir ao surgimento das grandes civilizações, à descoberta da agricultura, às grandes invenções da humanidade, ao nascimento da escrita e de todos os avanços que isso possibilitou. Neste 
sentido, desenvolvimento, progresso, evolução, todas estas palavras nos remetem à gênese e ao movimento histórico da humanidade, em busca de seu sentido na Terra.

Assim, foi com os filósofos gregos, em particular Aristóteles e Lucrécio, que a noção de desenvolvimento e evolução começou a ganhar forma, perdurando até aproximadamente o início do século XVII, onde novos paradigmas começaram a ser firmados sobre

[...] a evolução do real: o desejo e a possibilidade da mudança social, que tem por marco definitivo a Revolução Francesa; a crescente importância dos mecanismos de mercado repousando sobre o jogo de uma relativa livre concorrência, alavancada pela queda progressiva das monarquias europeias até a formação dos grandes impérios modernos; o progresso científico, com todo o rol de descobertas, inovações técnicas e especialização de saberes característicos do período inaugurado com o Iluminismo (FAVARETO, 2006, p. 38).

Mais adiante, para o mesmo autor, com a ruptura e transição referencial de explicação dos fenômenos, da filosofia grega para a filosofia medieval de Santo Agostinho, e desta para o racionalismo e empirismo moderno, estes últimos se tornando as formas de pensamento sistemático predominantes até os tempos atuais, ocorreu um deslocamento de significados na palavra desenvolvimento, onde as ideias de evolução e desenvolvimento foram incorporadas à ideia de evolução. Para Nisbet (1985), conforme o ideário inaugurado no Iluminismo, e aprofundado com a Revolução Industrial, a evolução se converteria naturalmente em progresso, alcançado pelo conhecimento e domínio das forças da natureza.

Assim, na virada do séc. XIX para o século XX, um novo paradigma se firmou, trazendo ressignificação ao conceito de desenvolvimento, agora associado à ideia de progresso, ocorrendo, com isso, a sua institucionalização no campo das ciências sociais e políticas, especialmente (FAVARETO, 2006).

É a partir daí, da modernidade, que surgem novos desdobramentos aos rumos do desenvolvimento, sob os impactos das ciências sociais, suscitando novos enfoques para além do crescimento econômico. Para Sen (2008), o grande desafio da atualidade é combater as iniquidades sociais que assolam grande parte da população mundial, por meio da formulação e implementação de novos mecanismos e orientações.

A atual conjuntura socioeconômica, política e cultural nos mostra que:

[...] vivemos igualmente em um mundo de privação, destituição e opressão extraordinárias. Existem problemas novos convivendo com antigos - a persistência da pobreza e de necessidades essenciais não satisfeitas, fomes coletivas e fome crônica muito disseminadas, violação de liberdades 
políticas elementares e de liberdades formais básicas, ampla negligência diante dos interesses e da condição de agente das mulheres e ameaças cada vez mais graves ao nosso meio ambiente e à sustentabilidade de nossa vida econômica e social (SEN, 2008, p. 9).

Antes da abordagem do desenvolvimento, a partir da perspectiva da expansão das liberdades, de Amartya Sen (2008), assunto bastante atual e que veremos mais adiante, o qual, de certa forma, servirá de pano de fundo para o diálogo com o conceito de autonomia, sigamos com a apresentação de mais algumas definições, visto que a contextualização histórica sobre o desenvolvimento é bastante extensa, e não cabe aqui maior aprofundamento, uma vez, ainda, que as informações até aqui apresentadas servem apenas de base introdutória ao conceito de desenvolvimento comunitário rural.

Ignacy Sachs $(2000$, p. 12; 15) nos diz que o desenvolvimento não pode ser reduzido simplesmente a um empreendimento socioeconômico, uma vez que ele "é uma percepção que molda a realidade, um mito que conforta sociedades, uma fantasia que desencadeia paixões" Diz, ainda, que "o termo estabelece um território comum, onde direita e esquerda, as elites e o povo se enfrentam em suas batalhas". Indiscutivelmente é uma palavra impregnada de significados e significantes. Como afirma Esteva (2000, p. 61),

[...] Não há nenhum outro conceito no pensamento moderno que tenha influência comparável sobre a maneira de pensar e o comportamento humano. Ao mesmo tempo, poucas palavras são tão ineficazes, tão frágeis e tão incapazes de dar substância e significado ao pensamento e comportamento.

Para alguns autores, como Amartya Sen (2008), Ignacy Sachs (2000) e José Eli da Veiga (2005; 2006), há inúmeras outras maneiras de conceber a ideia de desenvolvimento. Podemos ver isso nas suas concepções teóricas, que argumentam em favor da identificação do desenvolvimento por meio de outros indicadores, não apenas exclusivamente por meio do crescimento econômico, mas também incluindo aspectos avaliativos, como acesso a oportunidades sociais, liberdades políticas e também facilidades econômicas. Isso demonstra uma crítica radical à visão reducionista do desenvolvimento.

Um grande avanço nesta empreitada de combater os diversos problemas que enfrentamos e lançar novos olhares no campo do desenvolvimento foi dado pela Organização das Nações Unidas (ONU), quando esta inaugurou, no início de 1990, a noção de desenvolvimento humano, que ganhou expressão mundial através do Índice de 
Desenvolvimento Humano (IDH), como uma das principais medidas do desenvolvimento, indo além do Produto Interno Bruto (PIB) como elemento mensurador.

Para o Programa das Nações Unidas para o Desenvolvimento ${ }^{10}$,

Diferentemente da perspectiva do crescimento econômico, que vê o bemestar de uma sociedade apenas pelos recursos ou pela renda que ela pode gerar, a abordagem de desenvolvimento humano procura olhar diretamente para as pessoas, suas oportunidades e capacidades. A renda é importante, mas como um dos meios do desenvolvimento e não como seu fim. É uma mudança de perspectiva: com o desenvolvimento humano, o foco é transferido do crescimento econômico, ou da renda, para o ser humano.

Amartya Sen (2008, p.17) critica o enfoque do desenvolvimento identificado e medido apenas pelo incremento do Produto Nacional Bruto (PNB), bem como pelo mero "aumento de rendas pessoais, industrialização, avanço tecnológico ou modernização social'". Para o autor, o incremento da renda é visto apenas como um meio de expandir as liberdades desfrutadas pelos membros da sociedade. Neste sentido, ele argumenta que a expansão da liberdade deve ser vista como o principal meio do desenvolvimento, já que este "consiste na eliminação de privações de liberdade que limitam as escolhas e as oportunidades das pessoas de exercer ponderadamente sua condição de agente" (Ibid. p. 10). Essa "condição de agente", utilizada pelo autor, merece esclarecimento por ele próprio:

$\mathrm{O}$ agente às vezes é empregado na literatura sobre economia e teoria dos jogos em referência a uma pessoa que está agindo em nome de outra (talvez sendo acionada por um "mandante"), e cujas realizações devem ser avaliadas à luz dos objetivos de outra pessoa (o mandante). Estou usando o termo agente não nesse sentido, mas em sua acepção mais antiga _ e "mais grandiosa" - de alguém que age e ocasiona mudança e cujas realizações podem ser julgadas de acordo com seus próprios valores e objetivos, independentemente de as avaliarmos ou não também segundo algum critério externo (SEN, 2008, p. 33).

O desenvolvimento defendido pelo autor coloca em questão as perspectivas do modelo em voga, que reduzem o desenvolvimento ao crescimento do PNB ou ao incremento da renda pessoal. Para o autor, é um equívoco a avaliação do desenvolvimento a partir de indicadores meramente econômicos. O desenvolvimento, diz ele, é influenciado positivamente pelas “oportunidades econômicas, liberdades políticas, poderes sociais e por condições habilitadoras como boa saúde, educação básica e incentivo e aperfeiçoamento de iniciativas"

10 Explicação do PNUD sobre o que é desenvolvimento humano, disponível em: < http://www.pnud.org.br/IDH/DesenvolvimentoHumano.aspx>.

Universidade Lusófona de Humanidades e Tecnologias -FCSEA- Instituto de Educação 
(SEN, 2008, p. 19). A este conjunto de liberdades, o autor chama de desenvolvimento humano. Desta forma, continua ele, há duas razões para a liberdade se firmar como conceito central no processo de desenvolvimento: a primeira, denominada razão avaliatória, defende que o progresso deve ser medido a partir da expansão das liberdades das pessoas; a segunda, chamada de razão da eficácia, pressupõe que a realização do desenvolvimento depende inteiramente da livre condição de agente das pessoas.

Neste movimento de quebra de paradigmas, Sachs (2000) também nos diz que o desenvolvimento, que o mesmo chamou de 'eco-desenvolvimento', "não terá bom êxito sem a iniciativa, o engajamento e a imaginação populares necessárias à detecção correta dos objetivos sociais e à clarificação de soluções específicas exequíveis" (SACHS, 1986, p. 115).

No Brasil, outro economista compartilha a linha teórica de Sen, para analisar o desenvolvimento. José Eli da Veiga (2005; 2006) também discorda contundentemente da tentativa hegemônica de atribuir ao desenvolvimento o mérito do crescimento econômico discussão que, segundo ele, começou no final da década de 50, com o acelerado crescimento econômico, em contraste com a desigualdade social, a miséria e o analfabetismo. Para Veiga, a grande questão é que erroneamente os economistas convencionais continuam pensando o desenvolvimento e defendendo a segregação entre a ciência econômica e as variáveis do IDH. Eles têm a prerrogativa de estabelecer e avaliar os níveis do avanço educacional, cultural e em saúde, e até mesmo de analisar a liberdade e a democracia, além de indicar o desenvolvimento segundo padrões de crescimento econômico.

Nesta perspectiva, fica evidente o forte emprego do conceito de autonomia, em todo o discurso de Sen (2008) e Veiga (2005; 2006), sobre desenvolvimento. Discurso que harmoniza-se com a noção de sujeito histórico-social, agente de mudança, usada por Freire.

Reforçamos, nesta pesquisa, que uma das estratégias para o desenvolvimento e sua avaliação, é a importância e valorização da participação e da autonomia dos indivíduos, transformando-os em sujeitos de ação, o que pode ser entendido como a busca de um maior grau de conscientização e interferência no processo de dinamização socioeconômica e cultural da localidade, através da ação coletiva e organizada.

Por conseguinte, enfatizamos que através de uma participação decisória e integrada, de amplos contingentes da população local, é possível aproveitar o saber-fazer tradicional, o conhecimento detalhado da realidade e a vontade consciente de agir dos atores sociais. Uma participação não restrita aos indivíduos que possuem 'maior poder relacional', a exemplo das 
lideranças formais, mas que contemple, principalmente, aqueles mais vulneráveis, evitando, desta forma, a 'reprodução das assimetrias de poder'.

Nossa defesa, aqui, para além da educação como um direito e princípio libertador das heteronomias, é que não é mais possível conceber e aceitar o desenvolvimento sem atrelá-lo à ideia de promoção da autonomia dos sujeitos e à ampliação de suas capacidades e liberdades fundamentais; sem a oportunização, a estes, da conquista do poder como o conhecimento que possibilita a percepção crítica da realidade e a reação frente às injustiças e desigualdades sociais; sem destacar a diversidade cultural e o respeito à diferença, como importantes medidas de avaliação no processo desenvolvimentista; sem possibilitar que as populações rurais marginalizadas consigam se descobrir e se assumir como capazes de protagonizar suas próprias histórias de desenvolvimento, pessoal e social, sujeitos de ação e reedição - da história, da cultura, da vida. E é nesse movimento de ruptura, de ação, que a educação, ao longo da história, mostrou-se ser uma importante frente de luta.

Assim, indiscutivelmente, não há como desassociar formação de autonomia. A busca ou a promoção do empoderamento, com a possibilidade de oportunizar aos indivíduos, ou grupos de indivíduos, o acesso aos direitos sociais, passa, primeiro, pela educação.

\subsection{Panorama geral da pesquisa}

As pesquisas sobre o campo brasileiro, especialmente no que diz respeito ao desenvolvimento de comunidades rurais, empoderamento dos sujeitos trabalhadores/as e o papel da educação na construção de uma sociedade campesina mais consciente dos seus direitos e mais autônoma, no sentido de construção dos seus projetos de reforma agrária, tem aumentado consideravelmente nos últimos dez anos. Essas publicações contribuíram para dar visibilidade aos povos do campo e suas estratégias de resistência, que por muito tempo tiveram seus direitos negados e usurpados pelo Estado.

Segundo Molina (2006), durante o I Encontro Nacional de Pesquisa em Educação do Campo, foi reafirmada a impossibilidade de dissociação do debate sobre modelos de desenvolvimento econômico em disputa na sociedade brasileira e o papel do campo nestes diferentes modelos - o que referencia e legitima a pertinência desta pesquisa. Segundo a autora (2006, p. 10), “a especificidade da Educação do Campo em relação a outros diálogos sobre educação, deve-se ao fato de sua permanente associação com as questões do desenvolvimento e do território no qual ela se enraíza". 


\subsubsection{Caracterização da Pesquisa}

Para o desenvolvimento desta pesquisa, por sua natureza e complexidade, o enfoque metodológico adotado foi o da pesquisa qualiquantitativa, buscando examinar os diversos aspectos que envolvem a questão da autonomia e desenvolvimento comunitário rural, tomando por referência o universo abaixo descrito. Ainda que com características distintas, estes enfoques podem se complementar no processo investigativo.

De uma parte, a pesquisa se configura como quantitativa, visto que envolveu um intenso processo de coleta, sistematização e tratamento de dados numéricos que buscaram retratar tanto o perfil socioeconômico dos sujeitos, quanto os indicadores de desenvolvimento. Neste tipo de pesquisa, Segundo Diehl (2004), tanto na coleta quanto no tratamento das informações, faz-se uso das conhecidas técnicas da Estatística, objetivando resultados que evitam possíveis distorções de análise e interpretação, possibilitando uma maior margem de segurança. De acordo com Laville e Dionne (1999, p. 166) "os dados estatísticos são com frequência de fácil acesso e como são publicados a intervalos regulares, permitem seguir a evolução dos fenômenos e das situações no tempo".

De outra parte, configura-se como pesquisa qualitativa, que por sua vez, "caracterizase, principalmente, por estudar subjetividades, crenças, valores, representações da realidade, opiniões, enfim, fenômenos intrinsecamente complexos" (FAGUNDES, 2010, p. 21). Segundo Richardson et. al. (2009, p. 91), a pesquisa qualitativa "pode ser caracterizada como a tentativa de uma compreensão detalhada dos significados e características situacionais apresentadas pelos entrevistados".

No que se refere à classificação da pesquisa, quanto a seus objetivos, dado o seu caráter e dimensão, esta se converge em descritiva e exploratória. A pesquisa foi descritiva, pelo fato de ter descrito as características da população e seus sujeitos, com o estabelecimento de variáveis entre o MST e os assentados. Ainda, pelo fato de descrever as características sociais, políticas, econômicas, ambientais e culturais da comunidade, a fim de retratar seus ativos e passivos, e estabelecer seus indicadores de desenvolvimento. A pesquisa descritiva tem por "objetivo primordial a descrição das características de determinada população ou fenômeno ou, então, o estabelecimento de relações entre variáveis” (GIL, 2006, p. 42).

Também foi caracterizada como exploratória, porque buscou explicitar o fenômeno a partir da escuta dos sujeitos, em seu próprio espaço de vivência. Uma pesquisa qualitativa de 
natureza exploratória "possibilita familiarizar-se com as pessoas e suas preocupações" (POUPART et al., 2008, p. 130).

O trabalho está dividido em dois vértices: no primeiro, a realização de pesquisa bibliográfica, quando foram tomados por base primária os diversos livros, obras de referência, periódicos científicos, teses e dissertações, anais de encontros científicos etc.; no segundo, a pesquisa de campo, que buscou o aprofundamento da realidade estudada, a partir de um contato direto entre pesquisador e sujeitos, estabelecendo uma conversação continuada entre estes.

\subsubsection{Universo da Pesquisa}

O Assentamento Luiz Inácio Lula da Silva (Lulão), antiga Fazenda Coroa Cabrália, com área total aproximada de 650 hectares, está localizado no Município de Santa Cruz Cabrália, Costa do Descobrimento, Extremo Sul da Bahia, na altura do Km 22, às margens da rodovia BR 367, a 167m de altura, com latitude de 1638328135 e longitude de 39.38086867, encontrando-se a 46 km de Porto Seguro (BR 367), 03 km de Vera Cruz (BR 367) e 23 km de Eunápolis.

Atualmente, possui 57 famílias assentadas ${ }^{11}$ e uma população estimada em 228 habitantes, que vivem sob um sistema de moradia organizado em Agrovila, possuindo, cada assentado, uma área de produção individual de 5,00 hectares (3,4 de terra livre e 1,6 de reserva legal) e a possibilidade de participação em atividades coletivas de produção.

A partir da aplicação de questionário estruturado, direcionado aos assentados e assentadas originais $^{12}$ do Assentamento Luiz Inácio Lula da Silva, sendo a amostra composta por 15 homens e 15 mulheres, selecionados aleatoriamente dentre as 57 famílias assentadas pelo Governo Federal, em 2005, foi possível traçar um perfil socioeconômico e cultural desses sujeitos, com base em 39 perguntas agrupadas em 05 partes: identificação; escolarização/qualificação; renda pessoal, familiar e complementar; religiões, lazer e outras práticas culturais; e participação social e sociabilidades.

A amostra respeitou o critério previsto no Estatuto Social da Associação dos Pequenos Produtores Rurais do Assentamento Luís Inácio Lula da Silva, de que as decisões em assembleia geral sobre assuntos de interesse coletivo devem ser tomadas pela maioria

\footnotetext{
${ }^{11}$ Segundo dados da Secretaria Municipal de Saúde / Unidade Básica de Saúde (2016).

12 Assentados originais são aqueles que receberam do Governo Federal, a carta de posse da terra, quando da oficialização da área de assentamento, pelo INCRA.
} 
absoluta dos associados, ou seja, no mínimo 50\% mais 01 (um) dos associados com direito a voto, ou seja, os/as 57 associados/as originais. Assim, elegemos uma amostra de 30 pessoas, respeitando a divisão paritária e os critérios de gênero e geração.

\subsubsection{Sujeitos da Pesquisa}

Das trinta (30) pessoas entrevistadas, a maioria (26) tem mais de 10 anos no Movimento dos Trabalhadores Rurais Sem Terra (MST), oriundos, quase na totalidade (80\%), de bairros periféricos dos Municípios de Santa Cruz Cabrália, Porto Seguro e Eunápolis, Estado da Bahia, tendo participado das primeiras mobilizações do MST, realizadas no Extremo Sul, pelo direito a terra e em favor da Reforma Agrária, em meados de 2004. Os demais (20\%) são provenientes da zona rural, em sua grande maioria, pessoas que trabalhavam em fazendas da região.

Quanto ao local de nascimento, 63,33\% dos sujeitos pesquisados são de Municípios do Sul e Extremo sul da Bahia, sendo os restantes (36,67\%) nascidos em cidades dos Estados de Minas Gerais (23,34\%), Espírito Santo (10\%) e Pará (3,33\%).

Em relação à faixa geracional dos pesquisados, de acordo com o gráfico a seguir, podemos observar uma distribuição etária bastante interessante no Assentamento, com sujeitos de todas as idades: jovens, adultos e idosos.

\section{Gráfico 01 - Faixa geracional entre homens e mulheres}

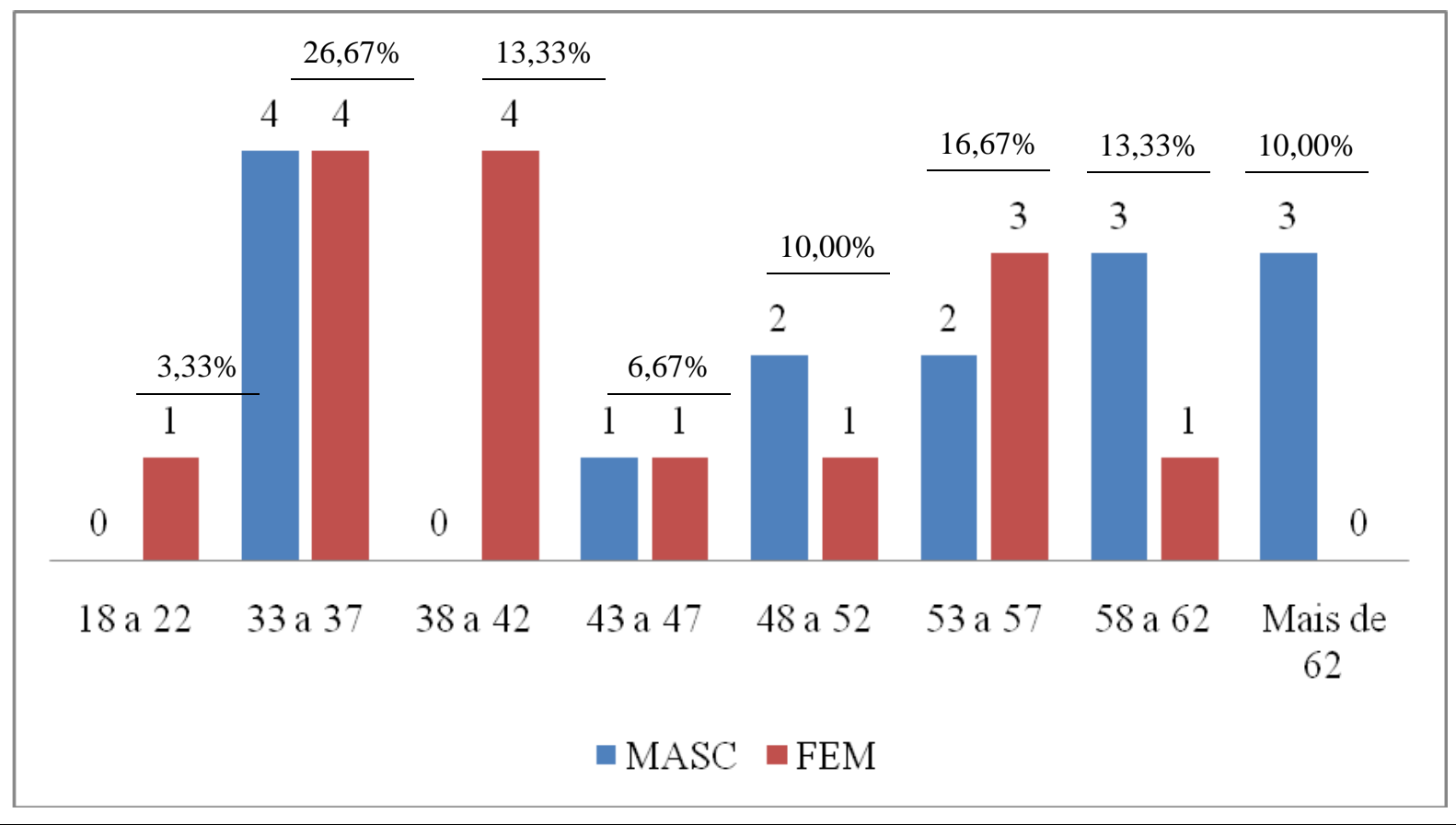

Universidade Lusófona de Humanidades e Tecnologias -FCSEA- Instituto de Educação 
A partir dos dados acima, podemos destacar: a existência de uma assentada jovem, com até 22 anos, casada com um dos assentados originais; uma maior prevalência de assentados/as entre 33 e 42 anos; um percentual de 10\% de assentados/as com idade superior a 62 anos.

Do contingente populacional pesquisado, $76,67 \%$ se autoidentificam como sendo pardos, sendo a grande maioria - 63,33\%, (19) - representada por pessoas casadas ou que vivem maritalmente. Os demais se encontram na condição civil de separados/divorciados/as $6,67 \%$ (2) - solteiros/as - 20\% (6) - e viúvos/as - 10\% (3).

No que diz respeito à prole, apenas um (1) dos entrevistados disse não possuir filhos. Quanto ao número de pessoas que residem no mesmo domicílio, 30\% dos entrevistados (9) moram com 04 (quatro) pessoas; 16,67\%, com 06 (seis) pessoas; 16,67\% moram com 03 (três); 13,33\%, com 02 (duas); e os demais (23,33\%) moram com 1, 5, 7, 8 ou 9 pessoas.

Referente ao grau de escolaridade, a metade (15), correspondente a 50\%, não concluiu o ensino fundamental (06 mulheres e 09 homens), apenas 02 pessoas são analfabetas $(6,67 \%)$, 04 concluíram o ensino fundamental (13,33\%), 05 fizeram o ensino médio $(16,67 \%)$ e os demais, 13,33\% (04 pessoas), estão igualmente assim distribuídos: ensino médio incompleto, ensino superior incompleto, ensino superior completo e pós-graduação incompleta.

\section{Gráfico 02 - Nível de escolaridade dos sujeitos pesquisados}

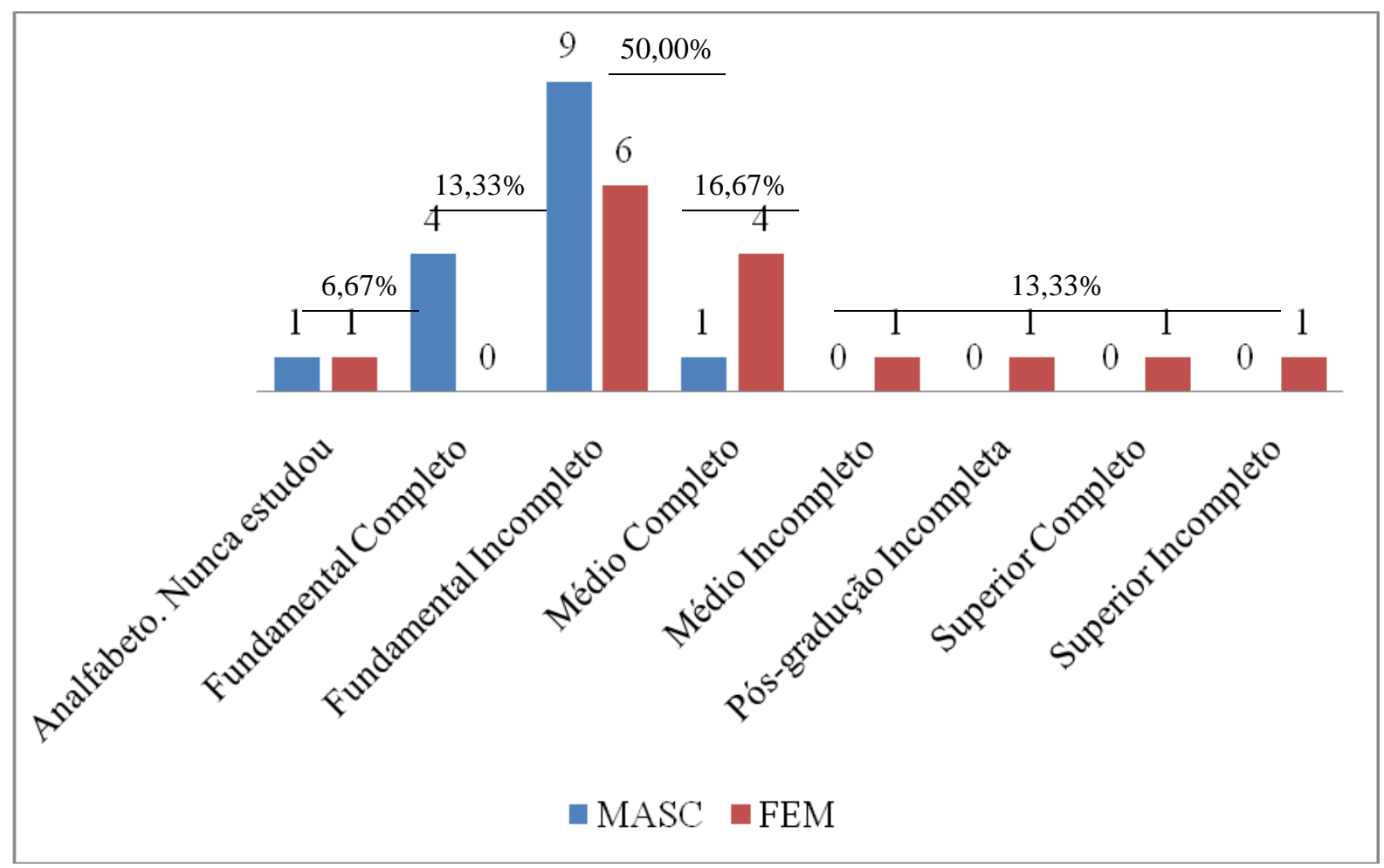


Altemar Felberg - Autonomia e Desenvolvimento Comunitário NO/DO Campo: Contradições e Consensos no Assentamento Luís Inácio Lula da Silva, do Movimento sem Terra - MST - em Santa Cruz Cabrália - Bahia/Brasil

Quanto ao grau de escolaridade dos genitores, 60\% (18) dos pais e 63,33\% (19) das mães são analfabetos (as); 30\% (9) dos pais e 30\% (9) das mães não concluíram o ensino fundamental, e apenas $10 \%$ (3) dos pais e 6,67\% (2) das mães o concluíram.

Sobre a qualificação profissional dos entrevistados, 66,67\% (20) já foram beneficiados pelo menos uma vez com cursos de inclusão socioprodutiva, realizados dentro do próprio Assentamento, por iniciativa de empresas do Sistema $S^{13}(95 \%)$, especialmente pelo Serviço Nacional de Aprendizagem Rural (SENAR). Os cursos são os mais variados possíveis, com destaque para os Cursos de Piscicultura (14,29\%), Criação de Galinha Caipira (9,52\%), Cerca Elétrica/Piquetes para sistema de pastejo rotacionado (9,52\%), Tratorista (9,52\%), Apicultura $(7,14 \%)$ e Cultivo da Banana (7,14\%), representando 57,13\% dos cursos realizados. Os cursos restantes, 42,86\%, estão distribuídos entre as atividades de beneficiamento de frutas, compostagem, inseminação artificial, manejo sanitário, informática, saúde e cultivo de hortaliças, cacau, pupunha e café, dentre outros.

No que concerne à atual ocupação, $73,33 \%$ (22) apenas trabalha $(86,63 \%$ autonomamente, por conta própria), $10 \%$ (3) não trabalha e nem estuda, 6,67\% (2) estão aposentados, e as 03 (três) outras pessoas, ou apenas estuda (3,33\%), trabalha e estuda (3,33\%), ou está desempregada (3,33\%). Do total de entrevistados/as, apenas 16,67\% (5) são empregados/as assalariados/as.

A atividade produtiva predominante é a agricultura familiar, correspondente a $80 \%$ (24) da opção dos assentados entrevistados, desenvolvida nos lotes individuais de terra $(3,4$ hectares de terra livre) com produção de banana, mandioca, pimenta do reino, milho, feijão, grãos em geral e hortifruticultura. A atividade é seguida pela bovinocultura $(6,67 \%)$, agricultura/apicultura $(3,33 \%)$ e agricultura/piscicultura $(3,33 \%)$. Duas pessoas disseram não desenvolver nenhuma atividade produtiva $(6,67 \%)$, individualmente. A agricultura também é a atividade produtiva predominante nos lotes coletivos $(93,33 \%)$, onde 09 hectares são destinados ao cultivo de café colonial, em regime sequeiro, 53 hectares destinados a áreas de pastagens, a exemplo da palma, e 06 hectares para plantio irrigado de goiaba, banana, manga, maracujá, abacaxi e açaí.

\footnotetext{
13 Termo que define o conjunto de organizações das entidades corporativas voltadas para o treinamento profissional, assistência social, consultoria, pesquisa e assistência técnica, que além de terem seu nome iniciado com a letra S, têm raízes comuns e características organizacionais similares. Fazem parte do sistema S: Serviço Nacional de Aprendizagem Industrial (Senai); Serviço Social do Comércio (Sesc); Serviço Social da Indústria (Sesi); e Serviço Nacional de Aprendizagem do Comércio (Senac). Existem ainda os seguintes: Serviço Nacional de Aprendizagem Rural (Senar); Serviço Nacional de Aprendizagem do Cooperativismo (Sescoop); e Serviço Social de Transporte (Sest). Fonte: http://www12.senado.leg.br/noticias/glossario-legislativo/sistema-s.
}

Universidade Lusófona de Humanidades e Tecnologias -FCSEA- Instituto de Educação 
Altemar Felberg - Autonomia e Desenvolvimento Comunitário NO/DO Campo: Contradições e Consensos no Assentamento Luís Inácio Lula da Silva, do Movimento sem Terra - MST - em Santa Cruz Cabrália - Bahia/Brasil

Referente à renda (remuneração dos fatores de produção) no Assentamento Lulão, $36,67 \%$ (11) declararam possuir renda pessoal/familiar/complementar de um a dois salários mínimos (entre $\mathrm{R} \$ 788$ e $\mathrm{R} \$ 1.576$ ); 30\% (9), menos de 1 salário mínimo (até $\mathrm{R} \$ 788$ ) e $33,33 \%$ (10) preferiram não declarar. Essas declarações corroboram os recentes dados divulgados pelo último Censo Demográfico, em 2010, de que o valor do rendimento nominal médio mensal dos domicílios particulares do campo é de $\mathrm{R} \$ 968,52$.

Quando perguntados sobre a participação na vida econômico-financeira da família, 43,33\% (13) disseram trabalhar e ser o principal responsável pelo sustento da família; $20 \%$ (6) afirmaram trabalhar e ser responsável pelo próprio sustento, contribuindo, ainda, parcialmente para o sustento da família; $16,67 \%$ (5) não trabalham e são sustentados por sua família ou outras pessoas; e os outros $20 \%$ (6) participam de outras maneiras, com registro de uma (1) pessoa aposentada e uma (1) desempregada. Na maioria, apenas uma (1) ou (2) pessoas contribuem para a renda da família, respectivamente 56,67\% (17) e 33,33\% (10).

No que diz respeito ao recebimento de benefícios do Governo Federal, 20 (vinte) pessoas $(66,67 \%)$ afirmaram recebê-los por meio dos seguintes programas: Bolsa Família ${ }^{14}$ (14), Bolsa Verde ${ }^{15}$ (1), Bolsa Família e Bolsa Verde (3) e Aposentadoria do INSS (2).

Sobre os bens que possuem em seus domicílios (eletrodomésticos, máquinas, equipamentos e veículos), foi apurado um total de 213 itens, com destaques para telefone celular (56), geladeira (38), televisão (36), motocicleta (19) e automóvel (6).

Quanto à disponibilidade e uso das ferramentas de comunicação, 21 pessoas disseram não ter, sob qualquer forma, acesso à internet (70\%). Dos que acessam (9), 05 (cinco) o fazem de casa, 03 (três) pelo celular/tablete, e 01 (um) no local de trabalho. Todos que acessam fazem uso de redes sociais, majoritariamente do Facebook.

Referente à frequência de acesso aos demais meio de comunicação (mídia impressa, falada e televisionada), os dados são os seguintes:

\footnotetext{
${ }^{14}$ Bolsa Família - é um programa de transferência de renda do Governo Federal que objetiva contribuir para o combate à pobreza e à desigualdade no Brasil (MDS, 2016).

${ }^{15}$ Bolsa Verde - programa do Governo Federal destinado àqueles que desenvolvem atividades de uso sustentável dos recursos naturais em Reservas Extrativistas, Florestas Nacionais, Reservas de Desenvolvimento Sustentável Federais e Assentamentos Ambientalmente Diferenciados da Reforma Agrária (MMA, 2016).
} 
Altemar Felberg - Autonomia e Desenvolvimento Comunitário NO/DO Campo: Contradições e Consensos no Assentamento Luís Inácio Lula da Silva, do Movimento sem Terra - MST - em Santa Cruz Cabrália - Bahia/Brasil

TABELA 01 - Acesso dos assentados/as aos meios de comunicação

\begin{tabular}{|c|c|c|c|c|c|c|c|c|c|c|}
\hline \multirow{2}{*}{$\begin{array}{c}\text { Meio de Comunicação } \\
\text { Jornais }\end{array}$} & \multicolumn{2}{|c|}{ Diariamente } & \multicolumn{2}{|c|}{$\begin{array}{c}\text { Quase } \\
\text { Diariamente }\end{array}$} & \multicolumn{2}{|c|}{ Às vezes } & \multicolumn{2}{|c|}{ Raramente } & \multicolumn{2}{|c|}{ Nunca } \\
\hline & 8 & $26,67 \%$ & 5 & $16,67 \%$ & 11 & $36,67 \%$ & 1 & $3,33 \%$ & 5 & $16,67 \%$ \\
\hline Revistas & 1 & $3,33 \%$ & 2 & $6,67 \%$ & 3 & $10,00 \%$ & 2 & $6,67 \%$ & 22 & $73,33 \%$ \\
\hline Livros & 2 & $6,67 \%$ & 5 & $16,67 \%$ & 9 & $30,00 \%$ & 1 & $3,33 \%$ & 13 & $43,33 \%$ \\
\hline Televisão & 16 & $53,33 \%$ & 9 & $30,00 \%$ & 4 & $13,33 \%$ & 1 & $3,33 \%$ & 0 & $0,00 \%$ \\
\hline Rádio & 6 & $20,00 \%$ & 4 & $13,33 \%$ & 8 & $26,67 \%$ & 6 & $20,00 \%$ & 6 & $20,00 \%$ \\
\hline Internet & 5 & $16,67 \%$ & 2 & $6,67 \%$ & 2 & $6,67 \%$ & 0 & $0,00 \%$ & 21 & $70,00 \%$ \\
\hline
\end{tabular}

Com base nos dados acima apresentados, pode-se constatar que há pouca adesão à mídia impressa (revistas e livros) entre os entrevistados, considerando-se que 43,44\% nunca leram um livro. $\mathrm{O}$ acesso ao lazer e entretenimento também é bastante restrito no Assentamento, conforme apresentado na tabela a seguir:

TABELA 02 - Acesso dos assentados/as a espaços de cultura, lazer e entretenimento

\begin{tabular}{|c|c|c|c|c|c|c|c|c|c|c|}
\hline \multirow{2}{*}{$\begin{array}{l}\text { Espaço de Cultura, Lazer e } \\
\text { Entretenimento } \\
\text { Cinema }\end{array}$} & \multicolumn{2}{|c|}{ Diariamente } & \multicolumn{2}{|c|}{$\begin{array}{c}\text { Quase } \\
\text { Diariamente }\end{array}$} & \multicolumn{2}{|c|}{ Às vezes } & \multicolumn{2}{|c|}{ Raramente } & \multicolumn{2}{|r|}{ Nunca } \\
\hline & 0 & $0,00 \%$ & 0 & $0,00 \%$ & 2 & $6,67 \%$ & 1 & $3,33 \%$ & 27 & $90,00 \%$ \\
\hline Teatro & 0 & $0,00 \%$ & 0 & $0,00 \%$ & 1 & $3,33 \%$ & 1 & $3,33 \%$ & 28 & $93,33 \%$ \\
\hline Estágio & 0 & $0,00 \%$ & 0 & $0,00 \%$ & 2 & $6,67 \%$ & 1 & $3,33 \%$ & 27 & $90,00 \%$ \\
\hline Museu & 0 & $0,00 \%$ & 0 & $0,00 \%$ & 1 & $3,33 \%$ & 0 & $0,00 \%$ & 29 & $96,67 \%$ \\
\hline Shopping & 0 & $0,00 \%$ & 0 & $0,00 \%$ & 5 & $16,67 \%$ & 4 & $13,33 \%$ & 21 & $70,00 \%$ \\
\hline Parque & 0 & $0,00 \%$ & 0 & $0,00 \%$ & 7 & $23,33 \%$ & 0 & $0,00 \%$ & 23 & $76,67 \%$ \\
\hline Shows & 0 & $0,00 \%$ & 0 & $0,00 \%$ & 8 & $26,67 \%$ & 2 & $6,67 \%$ & 20 & $66,67 \%$ \\
\hline Esporte & 1 & $3,33 \%$ & 0 & $0,00 \%$ & 2 & $6,67 \%$ & 2 & $6,67 \%$ & 25 & $83,33 \%$ \\
\hline Bares/Danceterias & 0 & $0,00 \%$ & 0 & $0,00 \%$ & 1 & $3,33 \%$ & 2 & $6,67 \%$ & 27 & $90,00 \%$ \\
\hline
\end{tabular}

A prática religiosa é bastante comum entre os assentados do Lulão, onde se registra 90\% de adesão/participação a algum tipo de religião. 51,85\% (14) frequentam igrejas protestantes (Adventista, Assembleia de Deus, Batista etc.), e 48,15\% (13) são católicos. Talvez, em virtude desta religiosidade, 66,66\% (20) prestam algum tipo de serviço assistencial ou trabalho voluntário, com destaque para iniciativas da própria comunidade e de associações religiosas $(41,67 \%)$. 
Ainda referente à participação social e sociabilidades dos assentados do Lulão, quase que a totalidade $(93,33 \%)$ é integrada à Associação dos Pequenos Produtores Rurais do Assentamento Luís Inácio Lula da Silva, participando ativamente dos eventos/ações promovidos pelo MST (assembleias, marchas, encontros etc.). Dois assentados disseram não fazer parte da Associação local.

\subsubsection{Instrumentos e Procedimentos de Coleta de Informações}

Preliminarmente à coleta das informações propriamente dita, foram realizadas reuniões com as lideranças representativas da comunidade e do MST - coordenadores regional, territorial (chefe de brigada), da área de assentamento, de saúde e de educação -, com o objetivo de, além de devidamente apresentar o projeto de pesquisa, obter a parceria institucional e aprovação necessárias à operacionalização da investigação pretendida.

\section{Fotografia $01^{16}-1^{\text {a }}$ reunião com lideranças do MST - 12/10/2015}

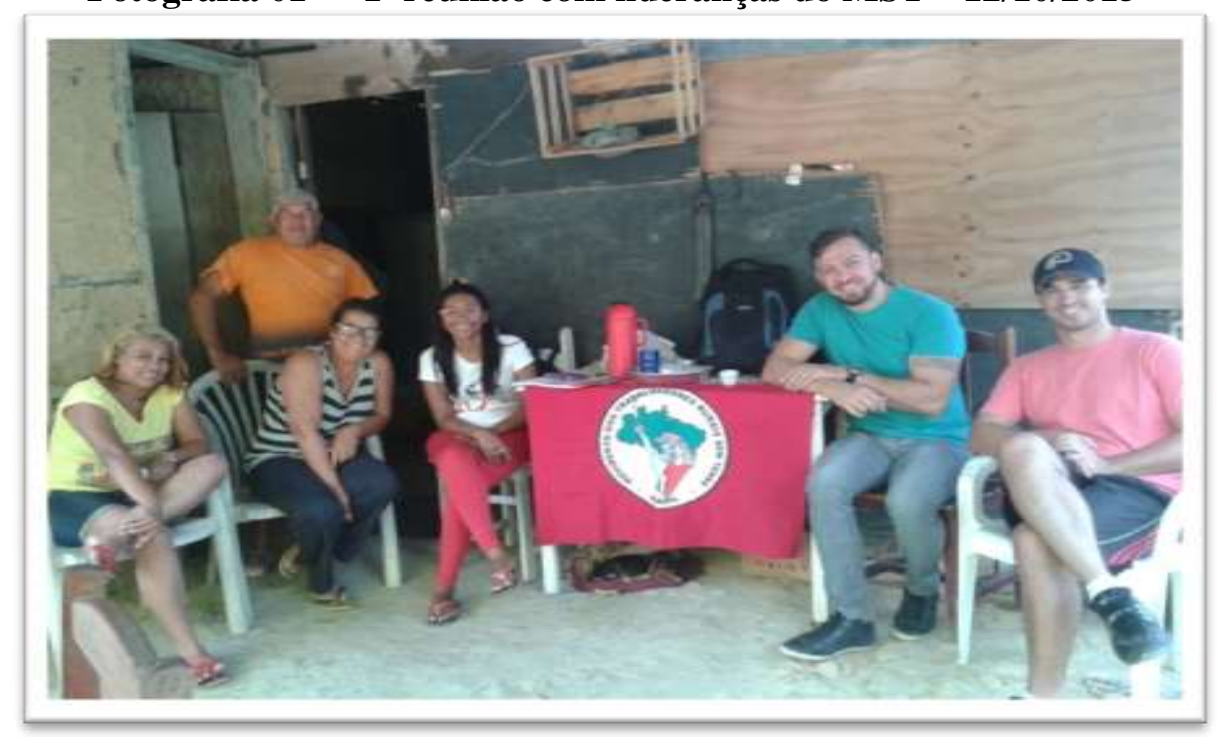

Levantados em gabinete, os primeiros dados sobre o objeto, partimos para a coleta das informações, por meio dos seguintes instrumentos:

\subsubsection{Questionários}

\section{A - Inventário Social}

\footnotetext{
${ }^{16}$ Todas as fotografias apresentadas neste trabalho foram autorizadas mediante Termo de Autorização e Cessão do Direito de Uso de Imagem e Voz e Termo de Consentimento Livre e Esclarecido. 
O primeiro questionário, composto essencialmente por questões abertas, buscou coletar dados e informações nas seguintes áreas: a) Perfil da População; b) Trabalho e Renda / Cadeia Produtiva / Segurança Alimentar; c) Qualificação de mão de obra; d) Infraestrutura local; e) Participação Social; f) Relação com o Meio Ambiente; g) Água; h) Resíduos Sólidos (Anexo 01).

Este tipo de instrumento parte "de uma série de perguntas abertas, feitas verbalmente em uma ordem prevista, mas na qual o entrevistador pode acrescentar perguntas de esclarecimento" (LAVILLE; DIONNE, 1999, p. 188).

Por meio deste instrumento foram realizados trabalhos de campo, onde foi feita uma caracterização de cenário (coleta de informações para caracterização sócio-políticoeconômico-ambiental e cultural da comunidade), além de ter sido reforçada a proposta da pesquisa junto às lideranças comunitárias e identificados os ativos sociais locais. Mais adiante, estas informações foram complementadas em gabinete, com dados e informações disponíveis em documentos e instâncias oficiais.

O Inventário Social possibilitou que a comunidade fosse caracterizada quanto à sua situação de infraestrutura, principais atividades econômicas, recursos naturais e humanos, problemas, impactos, passivos ambientais e sociais, lideranças e organizações. Mapear as características das comunidades é fundamental para o desenvolvimento e a definição de prioridades e formulação de políticas públicas voltadas à sua gestão territorial e ambiental.

A construção do instrumento baseou-se em ferramentas de coleta de informações já utilizadas pela Veracel Celulose S/A e o Instituto Mãe Terra ${ }^{17}$, em trabalhos desenvolvidos em comunidades da região do Sul da Bahia. Sua aplicação, realizada no dia 12 de outubro de 2015, ocorreu de forma tranquila, sem maiores complicações. As lideranças da comunidade receberam bem a proposta, e se colocaram à disposição para ajudar naquilo que fosse preciso, para o alcance dos objetivos traçados na pesquisa.

\section{B - Matriz de Vulnerabilidade Social}

Os dados e informações trazidas no Inventário Social alimentaram, ao final, um segundo instrumento metodológico previsto, também elaborado a partir de instrumentos já utilizados pela Veracel Celulose S.A e Instituto Mãe Terra, no trabalho com comunidades. Tal

\footnotetext{
${ }^{17}$ Organização Não Governamental (ONG) sediada no Município de Porto Seguro, da qual fazemos parte, que desenvolve projetos junto a comunidades rurais e tradicionais na região do Sul da Bahia.
} 
instrumento procurou mensurar o nível de vulnerabilidade do Assentamento Lulão, baseado nos indicadores de Educação, Saúde, Qualidade de Vida, Economia e Organização Social.

Considerando-se que este instrumento foi elaborado exclusivamente para refletir o nível de desenvolvimento ou de vulnerabilidade social do Assentamento, uma vez que não existe índice oficial sobre a comunidade em $\mathrm{si}^{18}$, não houve a necessidade, portanto, do mesmo ter sido aplicado in loco, apenas alimentado em gabinete, a partir de informações já anteriormente coletadas.

\section{C - Questionário Individual}

Posteriormente, foi utilizado um segundo questionário, composto por questões fechadas, com o objetivo de traçar o perfil socioeconômico e cultural dos sujeitos, aplicado ao longo de 02 semanas, a uma amostra composta por 15 homens e 15 mulheres, selecionados aleatoriamente, dentre as 57 famílias assentadas pelo Governo Federal. A aplicação do referido questionário respeitou o ritmo local e disponibilidade de cada um.

O instrumento foi composto por 39 (trinta e nove) perguntas agrupadas em 05 partes: identificação; escolarização/qualificação; renda pessoal, familiar e complementar; religiões, lazer e outras práticas culturais; participação social e sociabilidades. A amostra respeitou o critério previsto no Estatuto Social da Associação dos Pequenos Produtores Rurais do Assentamento Luís Inácio Lula da Silva, o qual já foi explicitado quando apresentamos o universo desta pesquisa.

Para testar a validade do instrumento, foi realizado um pré-teste com 05 pessoas, para verificar a estrutura e clareza das intervenções, com sujeitos que possuíam características análogas ao perfil do estudo. As dificuldades encontradas foram devidamente ajustadas para posterior aplicação, junto aos sujeitos da pesquisa.

A aplicação foi realizada individualmente, nas residências e em locais de trabalho (posto de saúde e escola), respeitando a aceitação prévia e disponibilidade de cada sujeito. Houve dificuldade com os assentados que estavam envolvidos na polinização do maracujá, visto que saíam bem cedo de casa e só retonavam ao final do dia, situação que foi contornada a partir da intervenção das lideranças, que mobilizaram este grupo para um encontro em horário alternativo.

18 O IDH dos Municípios não representa as diferentes realidades comunitárias. 


\subsubsection{Grupos Focais}

Trabalhamos, também, com entrevistas grupais, com dois grupos distintos: O primeiro grupo, composto por 05 (cinco) líderes, representantes legítimos das organizações sociais da comunidade (associação comunitária, escola, saúde, agroindústria e transporte); o segundo, formado por 06 (seis) jovens moradores do Assentamento Lulão, assentados/as e filhos/as de assentados, homens e mulheres, maiores de 18 anos.

\section{Fotografia 02 - Grupo focal 01}

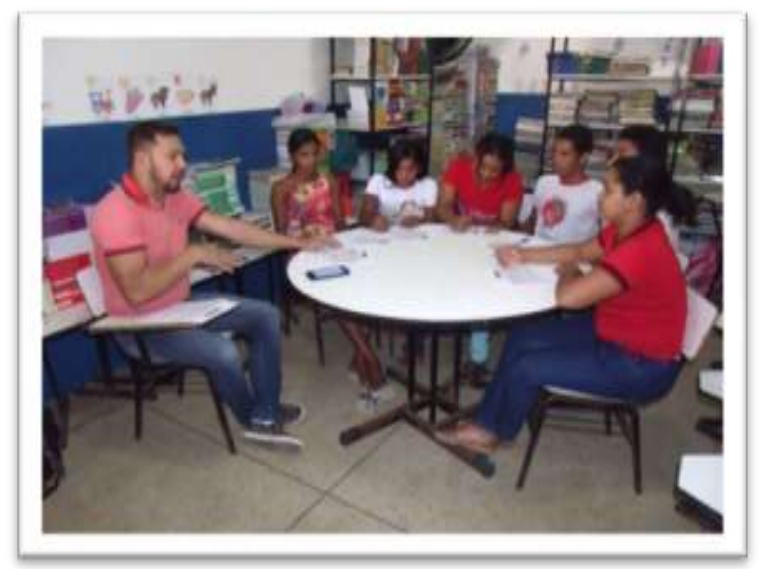

Fotografia 03 - Grupo focal 02

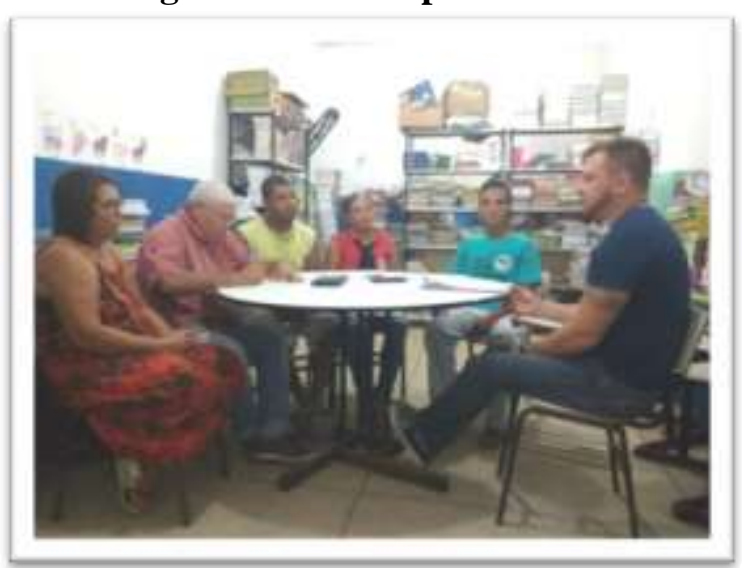

O método de grupos focais "consiste em reunir um grupo de pessoas para discutir coletivamente sobre um dado tema" (FAGUNDES, 2010, p. 46). A dinâmica de realização dos grupos focais "está voltada para um determinado foco que consiste do tema de pesquisa em questão e será discutido pelo grupo nas suas mais diversificadas dimensões possíveis dentro de um processo de interação e participação dos envolvidos" (TRENTINI; GONÇALVES, 2000 apud OLIVEIRA et. al., 2008, p. 1).

Morgan (1996, 1997), define o grupo focal como uma técnica de investigação de recolha de dados por meio da interacção do grupo sobre um assunto apresentado pelo investigador. Segundo o autor, tal definição abarca três componentes essenciais: os grupos focais são um método de investigação dirigido à coleta de dados; localiza a interação na discussão do grupo como a fonte dos dados; e, reconhece o papel ativo do investigador.

As entrevistas ocorreram na escola do assentamento, em dias e horários distintos. $\mathrm{O}$ primeiro grupo a ser entrevistado foi o composto por jovens moradores do assentamento, sem maiores dificuldades na condução. O segundo grupo foi o composto pelas lideranças locais, depois de algumas tentativas frustradas de reunião, em virtude da intensa agenda de eventos do MST, no período. 
Previamente ao diálogo, foi lido o Termo de Autorização e Cessão do Direito de Uso de Imagem e Voz e Termo de Consentimento Livre e Esclarecido, e solicitada a autorização para que as conversas fossem gravadas em vídeo e áudio. Todos concordaram em participar da pesquisa, e interagiram de forma satisfatória. As intervenções só eram feitas no sentido de melhor explicar as perguntas ou incentivar maior participação.

As entrevistas contribuíram de forma significativa, para o entendimento de algumas questões que os questionários não foram capazes de retratar. As histórias de vida foram o grande destaque das conversas, com relatos expressivos e emocionantes das trajetórias de lutas e conquistas no MST.

\subsubsection{Procedimentos de Análise das Informações}

A análise das informações procedeu-se de duas formas:

Primeiro, foram utilizadas as conhecidas técnicas da Estatística, para o tratamento do questionário individual, aplicado junto aos 30 assentados/as, bem como para a alimentação da matriz de vulnerabilidade social, conforme detalhado abaixo:

Questionário Individual: As respostas às 39 perguntas agrupadas em 05 partes (identificação; escolarização/qualificação; renda pessoal, familiar e complementar; religiões, lazer e outras práticas culturais; participação social e sociabilidades), foram sistematizadas em planilhas do Microsoft Excel e traduzidas estatisticamente em 46 (quarenta e seis) tabelas, algumas trazidas neste trabalho, e outras representadas em forma de gráficos. Os resultados obtidos com a aplicação deste questionário, distribuídos ao longo de todo o trabalho, foram utilizados na composição do perfil socioeconômico e cultural dos sujeitos, na caracterização da comunidade e na representação do sentido da autonomia, suas dimensões pessoal e social.

Matriz de Vulnerabilidade Social: Os parâmetros ou indicadores para mensurar o nível de vulnerabilidade da comunidade foram baseados no Índice de Pobreza Multidimensional (IPM), criado pelo Programa das Nações Unidas para o Desenvolvimento (PNUD), onde são mensurados indicadores nas áreas de educação (verificando a presença de escolas que atendam o Ensino Fundamental I e II e o Ensino Médio), saúde (verificando presença de unidades básicas de saúde) e qualidade de vida (verificando a disponibilidade e acesso a energia elétrica, telefonia, água encanada). Houve a necessidade de mensurar, também, os níveis economia (presença de agroindústrias coletivas e indústrias privadas) e organização social (presença de associações e cooperativas). Com base nas informações coletadas no 
Inventário, a cada equipamento disponível, e para cada presença de instituições que fortaleçam o desenvolvimento, foi atribuído um "X", que equivale a um ponto. Os pontos atribuídos a cada indicador foram multiplicados pelo Índice de Desenvolvimento Humano de cada município, chegando à nota de vulnerabilidade, representado em forma de mapa.

Segundo, para a análise das informações obtidas com o inventário social e com as entrevistas grupais realizadas, foi utilizada a técnica de análise de conteúdo, proposta por Laurence Bardin (1979), a qual contempla os seguintes passos:

1. A pré-análise, que consistiu na organização das entrevistas propriamente ditas. Através do material coletado, foi selecionado o que era pertinente à pesquisa;

2. A análise do material, a qual foi realizada na etapa de dissertação, já que nesta fase foi preciso tempo para codificar, categorizar e quantificar as informações colhidas;

3. O tratamento dos resultados, a inferência e a interpretação, que consistiram na produção final dos resultados da pesquisa ora apresentada.

A aplicação da técnica se deu da seguinte forma:

Inventário Social: Depois da realização do trabalho de campo, onde foi realizada uma caracterização do cenário (coleta de informações para caracterização sócio-políticoeconômico-ambiental e cultural da comunidade), a partir da aplicação do questionário com um grupo de lideranças, foi feito um levantamento secundário de dados e informações socioeconômicos e culturais sobre o Assentamento Lulão, em fontes oficiais, a exemplo do Instituto Brasileiro de Geografia e Estatística (IBGE) e órgãos das Secretarias Municipais de Saúde e Educação de Santa Cruz Cabrália (BA). O levantamento também contou com informações extraídas de um trabalho de conclusão de curso, apresentado por Jazian Mota dos Santos, à Faculdade de Educação da USP, em 2015, o qual apresentou um estudo sobre a relação comunidade e escola, em projetos voltados à agroecologia. Ao final, todas as informações foram categorizadas nos eixos previstos no instrumento e apresentadas no decorrer do trabalho.

Grupos Focais: No tratamento das entrevistas grupais foram utilizadas as normas e critérios propostos por Marcuschi (1986), as quais recentemente vêm sendo adotadas com maior frequência pelos pesquisadores em educação. Primeiro, no momento da entrevista, no processo de coleta de dados, focalizamos nossa atenção no processo de interação verbal e social com os sujeitos entrevistados, concentrando-nos nas respostas, explicações e argumentações. Segundo, no momento da transcrição, nos distanciamos do papel de pesquisador-entrevistador e nos colocamos no papel de interpretador das informações, 
Altemar Felberg - Autonomia e Desenvolvimento Comunitário NO/DO Campo: Contradições e Consensos no Assentamento Luís Inácio Lula da Silva, do Movimento sem Terra - MST - em Santa Cruz Cabrália - Bahia/Brasil

transcrevendo o que foi dito e se atendo, também, àquilo que não foi respondido ou que ficou inaudível. Marcuschi compilou quatorze sinais que considera mais frequentes e úteis para a realização de uma transcrição, e estes foram utilizados com fidelidade neste trabalho. Nesta etapa, como bem destaca o autor, o pesquisador deve ter clareza dos objetivos da sua pesquisa e assinalar o que lhe convém para análise. Terceiro, no momento da interpretação, os excertos mais significativos foram categorizados e compuseram um quadro analítico, trazendo os resultados finais dos grupos focais. Este tipo de análise, segundo Canzonieri (2010, p. 90), refere-se a uma "análise idiossincrática, que é a redução da fala do sujeito em unidades significativas, que trazem o significado dado pelo sujeito ao fenômeno". 


\section{CAPITULO II}

\section{AUTONOMIA NA CONTEMPORANEIDADE: O "PENSAR AUTÔNOMO" SEGUIDO DO "FAZER AUTÔNOMO"}


Altemar Felberg - Autonomia e Desenvolvimento Comunitário NO/DO Campo: Contradições e Consensos no Assentamento Luís Inácio Lula da Silva, do Movimento sem Terra - MST - em Santa Cruz Cabrália - Bahia/Brasil

O exercício da autonomia depende de seu ambiente biológico, cultural ou social; tem como condições essenciais a 'liberdade' (independência do controle de influências) e a 'ação' (capacidade de ação intencional); está intimamente relacionado ao conceito de poder, com a ressalva de um 'poder para' e não um 'poder sobre'; representa o estado de consciência e liberdade que deve ser vivenciada a favor do desenvolvimento e da coletividade; configura-se como a capacidade das pessoas, de se assumirem enquanto seres sociais, sujeitos de direitos e protagonistas de suas próprias histórias de desenvolvimento, pessoal e social; traduz-se como um recurso capaz de livrar os indivíduos não só da opressão sobre as suas liberdades (de escolha e de ação), mas também da miséria, desamparo e alienação; e, especialmente, é uma das mais importantes medidas na avaliação do desenvolvimento. Como diz Sen (2008, p. 19) "a liberdade de participação ou dissensão política ou as oportunidades de receber educação básica são ou não são conducentes ao desenvolvimento".

Isaiah Berlin (1909-1997), filósofo político britânico, considerado um dos principais pensadores liberais do século XX, em seus ensaios sobre liberdade positiva e liberdade negativa, traz importante contribuição à compreensão da autonomia na contemporaneidade. Na interpretação de Godinho (2011),

Tal como Benjamim Constant e Norberto Bobbio, Isaiah Berlin entende que a liberdade dos antigos é a liberdade vista como autonomia e que a liberdade dos modernos é a liberdade enquanto ausência de obstáculos para a ação individual. Mas Isaiah Berlin acrescenta algo. Para Berlin, a liberdade dos antigos, por ele denominada liberdade positiva, relaciona-se com a resposta à pergunta: "Por quem sou governado?". Já a liberdade em seu sentido moderno, que ele chamou liberdade negativa, está implicada na resposta à pergunta: "Qual o grau de interferência alheia em minha vida?" (GODINHO, 2011, p. 53).

Nessa assertiva, ainda segundo o autor, percebe-se que Berlin (1981) insinua a negação da liberdade positiva dos antigos, colocando, assim, a liberdade moderna em destaque, digna do nome (liberdade). Desta forma, Berlin considera que "um sujeito é livre na medida em que não o impedem de fazer o que ele quer, na medida em que não interferem em suas ações" (apud GODINHO, 2011, p. 54). Para tanto, ele explica a liberdade negativa da seguinte forma:

O sentido fundamental de liberdade é a liberdade dos grilhões, do aprisionamento, da escravidão por outros. O resto é extensão desse sentido, ou então é metáfora. Lutar para ser livre é procurar remover obstáculos; lutar pela liberdade pessoal é procurar pôr freio na interferência, exploração e escravização por parte de homens cujos fins são deles mesmos e não nossos (BERLIN, 1981, p. 32). 
Altemar Felberg - Autonomia e Desenvolvimento Comunitário NO/DO Campo: Contradições e Consensos no Assentamento Luís Inácio Lula da Silva, do Movimento sem Terra - MST - em Santa Cruz Cabrália - Bahia/Brasil

Maria da Glória Gohn (2009), em sua coletânea acerca das novas teorias sociais contemporâneas sobre os movimentos sociais, confirma que as temáticas sobre autonomia e emancipação voltam à cena acadêmica da atualidade nos argumentos de Castoriadis (1975) e Adorno (1984), dentre outros.

Para Castoriadis (1982), a autonomia pode ser definida como o domínio do consciente sobre o inconsciente, visto que, é no campo da inconsciência que reside o discurso do outro, que fala por mim e que interfere minha vontade. "O sujeito não se diz, mas é dito por alguém, existe como parte do mundo de um outro. O sujeito é dominado por um imaginário vivido como mais real que o real, ainda que não sabido como tal" (CASTORIADIS, 1982, p. 124).

Schweppenhäuser (2003), analisando a obra de Adorno, da Escola de Frankfurt, em especial na minúcia de seus comentários e interpretações nos cursos de 1963, em que aparece no seu teorema ético um novo imperativo categórico depois de Auschwitz, ${ }^{19}$, percebe o quanto as ideias do autor confluem com a filosofia moral crítica de Kant.

Hitler impôs aos seres humanos, em seu estado de não-liberdade, um novo imperativo categórico: pensar e agir para que Auschwitz nunca mais se repita, para que nada de semelhante possa se repetir. Este imperativo é tão refratário à sua fundação como o fora uma vez o dado do imperativo kantiano. Seria um sacrilégio tratá-lo discursivamente: nele se faz sentir corporalmente na moralidade o momento de seu surgimento. (ADORNO, 1984, p. 358 apud SCHWEPPENHÄUSER, 2003, p. 407-408)

Um ponto de convergência entre Kant (1974) e Adorno (1984) pode ser caracterizado pela "reflexão normativa fundadora e aquilo que se relaciona com a situação histórica dos problemas éticos" (SCHWEPPENHÄUSER, 2003, p. 408). Detalhadamente,

A confiança fundamentada de Kant em poder realizar a autonomia de indivíduos livres como princípio de socialização dá passagem em Adorno para a consciência de que só se pode tratar agora de combater o estranhamento universal dos homens, causado por suas relações sociais antagônicas, o tanto quanto for possível. A pretensão de validade do imperativo categórico, ela mesma categórica, e que se oferece como incondicional e por conta de si própria, deveria ser garantida em Kant por seu caráter formal, no entanto, valer ao mesmo tempo como um "fato da razão". Em Adorno, tal pretensão de validade acontece pela ligação com a experiência histórica, pelo interesse na abolição do sofrimento, e, por meio de seu caráter heterônomo - heterônomo apenas neste aspecto - não se conduz ad absurdum. Pois cada máxima ética formulada positivamente, independentemente de se relacionar pelo conteúdo com a vida boa, ou

19 Auschwitzé o nome de uma rede de campos de concentração localizados no sul da Polônia operados pelo Terceiro Reich nas áreas polonesas anexadas pela Alemanha Nazista, maior símbolo do Holocausto.

Universidade Lusófona de Humanidades e Tecnologias -FCSEA- Instituto de Educação 
formalmente com a ação correta, deve dar meia-volta diante da realidade histórica catastrófica que se manifestou em Auschwitz. Adorno parte do fato de que não mais podemos dizer o que deve ser, mas apenas aquilo que não pode acontecer (SCHWEPPENHÄUSER, 2003, p. 408).

Segundo Schweppenhäuser (2003), o contributo de Adorno ao desenvolvimento do conceito de autonomia refere-se à critica que este fez ao Iluminismo. Para Adorno - na análise de Schweppenhäuser -, a finalidade desta corrente intelectual era de libertar a humanidade do medo, liberando os homens do misticismo, admitindo que tal objetivo pudesse ser alcançado por meio da ciência e da tecnologia.

Desta forma, para Adorno (1984), tudo levaria a entender que o iluminismo instauraria o poder do homem sobre a ciência e sobre a técnica. Contudo, ao invés disso, ainda que liberto do medo mágico, o homem tornou-se novamente vítima, agora do progresso da dominação técnica. Esta foi a crítica que Adorno (1999, p. 109) fez ao iluminismo, a qual nos remete fortemente ao conceito de autonomia, pois, segundo ele, o iluminismo dos anos 40, do século XX, "impede a formação de indivíduos autônomos, independentes, capazes de julgar e de decidir conscientemente". Como consequência, são incapazes de constituir uma sociedade democrática, que não se pode manifestar senão por meio de homens livres.

Nos últimos tempos, diversos outros autores contemporâneos contribuíram com a noção de autonomia, considerando-se as muitas heteronomias que se apresentam no atual contexto histórico mundial, as quais Freire denunciou, em seu discurso. Um contributo importante da filosofia contemporânea à noção de autonomia é o de Marilena Chauí (2000, p. 443):

A razão prática é a liberdade como instauração de normas e fins éticos. Se a razão prática tem o poder para criar normas e fins morais, tem também o poder para impô-los a si mesma. Essa imposição que a razão prática faz a si mesma daquilo que ela própria criou é o dever. Este, portanto, longe de ser uma imposição externa feita à nossa vontade e à nossa consciência, é a expressão da lei moral em nós, manifestação mais alta da humanidade em nós. Obedecê-lo é obedecer a si mesmo. Por dever, damos a nós mesmos os valores, os fins e as leis de nossa ação moral e por isso somos autônomos.

Ferrater Mora (1965) nos traz a definição de autonomia como uma realidade que é regida por uma lei própria. $\mathrm{O}$ autor sugere dois sentidos para o termo. O sentido argumentativo ontológico e o sentido ético. O primeiro se refere a esferas da realidade, que são autônomas e independentes em relação às outras, ou seja, qualquer coisa que existe é vista 
como algo que é; nada há mais do que isso. O segundo refere-se a uma lei moral que tem em si seu fundamento e a razão da própria lei.

Segundo Abbagnano (1962), a expressão genérica 'princípio autônomo' é bastante utilizada no sentido de que o princípio tenha, em si, ou coloque por si mesmo, a sua validez ou a regra de sua ação. Para o autor, o termo autonomia, foi introduzido por Kant, para designar a independência da vontade em relação a qualquer desejo ou objeto de desejo, e a sua capacidade de determinar-se em conformidade com uma lei própria, que é a da razão.

Ângela Maria Martins (2001, p. 25), para a qual "a autonomia é um empreendimento da humanidade e um programa de reflexão filosófica sobre o indivíduo há vinte e sete séculos”, traz mais um conceito de autonomia na perspectiva filosófica de Castoriadis (1991), isto é:

[...] o pressuposto e ao mesmo tempo o resultado da ética tal como a viram Platão ou os estóicos, Spinoza ou Kant (...). Se à autonomia, a legislação ou a regulação por si mesmo, opomos a heteronomia, a legislação ou a regulação pelo outro, a autonomia é minha lei, oposta à regulação pelo inconsciente que é uma outra lei, a lei de outro que não eu' (CASTORIADIS, 1991, p. 123).

Esta perspectiva considera, também, que na história mais recente da humanidade, instituiu-se uma tensão entre os movimentos autônomos e o conjunto de instituições sociais cuja função tem sido a de garantir a reprodução das relações sociais de produção, a partir, sobretudo, do advento da sociedade capitalista. Deste modo, as possibilidades e limites para o exercício da autonomia são dados, historicamente, por um conjunto de fatores. Ela só pode ser definida, portanto, como relação social, pois "não podemos desejar a autonomia sem desejá-la para todos, e sua realização só pode conceber-se como empreitada coletiva" (CASTORIADIS, 1991, p. 130).

O autor lança reflexões acerca das relações entre práxis e projeto, enfatizando que a primeira noção está indubitavelmente relacionada à ideia de que os outros são visados como seres autônomos e "considerados como o agente essencial do desenvolvimento de sua própria autonomia [pois] a verdadeira política, a verdadeira pedagogia, a verdadeira medicina, na medida em que algum dia existiram, pertencem à práxis" (CASTORIADIS, 1991, p. 94). Porém, na práxis, a autonomia dos outros não é um fim, ela é sempre um começo, pois não é finita. Existe uma relação intrínseca entre o que é visado - o desenvolvimento da autonomia e aquilo por que ela é desejada - seu exercício, pois ambos os desejos constituem dois momentos de um mesmo processo. 
Neste sentido, Castoriadis (1992, p. 148) também afirma que:

A autonomia é, portanto, o projeto - e agora estamos ao mesmo tempo no plano ontológico e no plano político - que visa, no sentido amplo, ao nascimento do poder instituinte e sua explicitação reflexiva (que sempre só podem ser parciais). E, no sentido mais preciso, esse projeto visa à reabsorção do político, como poder explícito, na política, atividade lúcida e deliberada tendo por objeto a construção explícita da sociedade.

No questionamento acerca do conceito de projeto revolucionário, preconizado pela ortodoxia soviética, Castoriadis ressalta que as políticas liberais tratam os homens como objetos, a partir de seus bens materiais e de suas relações supostamente conhecidas.

$\mathrm{O}$ autor discute o próprio conteúdo do projeto revolucionário, que é precisamente a reorganização e a reorientação da sociedade pela ação autônoma dos homens. A consolidação social e histórica da autonomia, diz ele, não pode ser confundida com a ideia de liberdade abstrata registrada nos princípios liberais que permeou até mesmo o marxismo, já que essa consolidação ocorreu no bojo do processo de constituição subjetiva do sujeito e constituiu um fenômeno intrínseco às relações sociais.

Castoriadis (1991), no seu diálogo com o socialismo soviético, defende a autonomia como eixo condutor de movimentos autogestionários, passíveis de modificar as relações sociais de produção. Segundo o autor, ela se opõe à estatização dos meios de produção, à centralização das decisões no aparelho de Estado e à homogeneização das individualidades. $\mathrm{O}$ socialismo construído nos moldes do modelo soviético não significava a possibilidade de instauração de uma nova ordem em que a liberdade - não abstrata - pudesse ser praticada, porque representava, na visão de Castoriadis, o antagonismo fundante de sua própria destruição.

Nesse ponto de vista, em uma sociedade de alienação, a autonomia como prática social sempre será permeada pelas condições materiais de existência e por outros indivíduos, porque "a ideia da autonomia e da responsabilidade de cada um por sua [própria] vida pode facilmente tornar-se mistificação se a separarmos do contexto social e se a estabelecermos como resposta que se basta a si mesma" (CASTORIADIS, 1991, p. 131).

A alienação, a heteronomia social, não aparece simplesmente como 'discurso do outro'. O 'outro' desaparece no anonimato coletivo, na impessoalidade dos 'mecanismos econômicos do mercado' ou da racionalidade do plano, da lei de alguns apresentada como lei simplesmente. A alienação surge como, pois instituída, pelo menos como grandemente condicionada pelas instituições (estrutura das relações reais de produção). (CASTORIADIS, 1991, p. 131). 
Como relação e prática social, a autonomia será sempre o produto de uma conjuntura histórica, e nunca a resposta definitiva para contradições e conflitos sociais, insondáveis e imprevisíveis.

Já na perspectiva freiriana, autonomia tem a ver com o que Freire chama de 'ser para si', e no contexto histórico subdesenvolvido dos oprimidos para quem e com quem Freire escreve, autonomia está relacionada com a libertação. "A autonomia, como amadurecimento do ser para si, é um processo, é vir a ser" (FREIRE, 2000, p. 121), ou seja, uma experiência de liberdade, que se constrói nas decisões do sujeito, em seu processo de participação democrática. Na sua construção do conceito de autonomia, o autor denuncia, de forma contundente, as heteronomias do sistema, e incita todos nós a promovermos uma educação transformadora, que leve em consideração e respeite a autonomia do sujeito, que promova sua emancipação e lhe dê as condições necessárias para despontarem socialmente como protagonistas de suas histórias de desenvolvimento, livres da opressão e da privação de oportunidades sociais e econômicas. Em síntese, a práxis da libertação de Freire defende a ideia de uma educação voltada para a libertação, conduzindo as pessoas a serem autônomas, a serem para si, a alcançarem a humanidade.

Reforçando esta ideia, Chauí (1990, p. 302) nos diz que “autonomia é a posição de sujeitos (sociais, éticos, políticos) pela ação efetuada pelos próprios sujeitos enquanto criadores das leis e regras da existência social e política", a partir de seu entendimento de que os conceitos de autonomia e participação possuem tênue relação.

Dessa forma, sua construção e consolidação envolvem dois aspectos: o poder de determinar a si uma lei própria e, também, o poder ou capacidade de realizar, de concretizar este estado, colocando em prática a recente expansão de liberdades e capacidades. "O primeiro aspecto está ligado à liberdade e ao poder de conceber, fantasiar, imaginar, decidir e, o segundo, ao poder ou capacidade de fazer" (ZATTI, 2007, p. 14).

Neste sentido, segundo Goldim (2004, p. 2), em sua grande maioria, as teorias sobre a temática "concordam que duas condições são essenciais à autonomia: "liberdade" (independência do controle de influências) e "ação" (capacidade de ação intencional)".

Complementando essa assertiva, e o que dá base para esta capacidade de conceber e realizar, Freire (2007) nos incita a um posicionamento ético no mundo, como seres históricoculturais, e a buscarmos nosso estado de seres autônomos e conscientes. Percebe-se isso quando o mesmo diz: “Afinal, minha presença no mundo não é a de quem a ele se adapta, mas 
Altemar Felberg - Autonomia e Desenvolvimento Comunitário NO/DO Campo: Contradições e Consensos no Assentamento Luís Inácio Lula da Silva, do Movimento sem Terra - MST - em Santa Cruz Cabrália - Bahia/Brasil

a de quem nele se insere. É a posição de quem luta para não ser apenas objeto, mas sujeito também de História" (FREIRE, 2007, p. 54).

Assim, para que haja autonomia, com base na ideia acima, o pensar autônomo precisa ser seguido de um fazer autônomo. Como defende Castoriadis e Freire, não basta chegar a tal estado de consciência e liberdade se esta recente autonomia não for vivenciada a favor do desenvolvimento, da coletividade. "Quem pensa certo está cansado de saber que as palavras a que falta a corporeidade do exemplo pouco ou quase nada valem. Pensar certo é fazer certo" (FREIRE, 2007, p. 34).

Seguindo esta linha de pensamento, Freire (1986, p 135) reforça que:

Mesmo quando você se sente, individualmente, mais livre, se esse sentimento não é um sentimento social, se você não é capaz de usar sua liberdade recente para ajudar os outros a se libertarem através da transformação da sociedade, então você só está exercitando uma atitude individualista no sentido do empowerment ou da liberdade.

Retornando a Goldim (2004), este traz a visão de Charlesworth, sobre a noção de autonomia, introduzindo uma perspectiva social ao conceito, conduzindo-o à própria noção de cidadania. Charlesworth (apud Goldim, 2004, p. 1) diz que:

Ninguém está capacitado para desenvolver a liberdade pessoal e sentir-se autônomo se está angustiado pela pobreza, privado da educação básica ou se vive desprovido da ordem pública. Da mesma forma, a assistência à saúde básica é uma condição para o exercício da autonomia.

Importa destacar, também, o pensamento de Hegel, para o qual a liberdade se dá num contexto histórico-dialético, ou seja:

No conceito de liberdade hegeliano, não é a vontade - enquanto 'faculdade de desejar superior' definida por Kant (1994) - que é racional. Racional é a efetividade do mundo concreto. A autonomia aqui não é a oposição formal da razão versus a sensibilidade, haja vista que a própria sensibilidade humana, enquanto natureza intrínseca ao homem, se humaniza ao longo do processo histórico e civilizatório. A autonomia é a capacidade do mundo humano em racionalmente avançar para normas éticas cada vez mais universais, superando a particularidade dos indivíduos e dos povos (SILVA, 2012, p. 4-5).

Sendo assim, a partir destas concepções, o fazer não acontece fora do mundo, uma vez que nossa relação com o que nos é externo, com a sociedade em que vivemos, é o que nos molda e remodela nossos comportamentos e posturas diante da vida. Como ser natural, mas 
também social, estamos submetidos às leis da natureza, à legislação vigente, às convenções e regras da sociedade etc., ou seja, a autonomia é limitada por condicionamentos; não é absoluta, como dito anteriormente. Pode-se dizer, então, que autonomia jamais pode ser confundida com autossuficiência. Entretanto,

Isto não significa negar os condicionamentos genéticos, culturais, sociais a que estamos submetidos. Significa reconhecer que somos seres condicionados, mas não determinados. Reconhecer que a História é tempo de possibilidade e não de determinismo, que o futuro, permita-se-me reiterar, é problemático e não inexorável (FREIRE, 2007, p. 19).

A temática da autonomia encontra em Freire (1983) um sentido sócio-políticopedagógico, traduzido na práxis da libertação. A autonomia é a condição sócio-histórica do sujeito, ou seja, a capacidade das pessoas de se assumirem enquanto seres sociais sujeitos de direitos e protagonistas de suas próprias histórias de desenvolvimento, pessoal e social. E conquistar a própria autonomia implica, para Freire, em libertação das estruturas que oprimem o indivíduo. Foi esta perspectiva sensível, prática e libertadora, a grande contribuição de Freire ao conceito de autonomia. "A libertação a que não chegarão pelo acaso, mas pela práxis de sua busca; pelo conhecimento e reconhecimento da necessidade de lutar por ela" (FREIRE, 1983, p. 32). Essa discussão freireana é corroborada por Zatti (2007, p. 62), ao afirmar que:

Não há libertação que se faça com homens e mulheres passivas, é necessária conscientização e intervenção no mundo. A autonomia, além da liberdade de pensar por si, além da capacidade de guiar-se por princípios que concordem com a própria razão, envolve a capacidade de realizar, o que exige um homem consciente e ativo, por isso o homem passivo é contrário ao homem autônomo.

Para Lyra (2005, p. 63), “essa autonomia se exerce na tomada de decisões, na capacidade de uma avaliação independente dos problemas, na capacidade de conceber soluções apropriadas e na determinação de colocá-las em prática”. Essa concepção de autonomia é bastante conhecida em metodologias de intervenção comunitária, e faz menção ao 'pensar certo e agir certo' de Freire, incitando a emancipação e o protagonismo dos sujeitos a partir deles próprios. Neste sentido, Lyra (2005, p. 26) nos apresentada a expressão fantasias mobilizadoras, que "impulsionam o indivíduo a 'levantar-se puxando os cordões dos próprios sapatos', a ser autônomo e acreditar na sua capacidade de realizar mudanças”. 
Cara Lyra (2005) ainda nos diz que o conceito de autonomia está intimamente relacionado ao conceito de poder, com a ressalva de um 'poder para', e não um 'poder sobre'. Desta forma, relaciona o princípio autônomo ao "processo de potencialização do indivíduo sem entrar em relações de dominação" (LYRA, 2005, p. 116).

Edgar Morin (2006) também dá a sua contribuição para se compreender o conceito de autonomia na contemporaneidade, focando-a, assim como Kant outrora fez, na capacidade do sujeito de conceber e fazer escolhas, a partir da sua racionalidade, independente e particular. Percebe-se isso, quando ele nos diz que:

\begin{abstract}
A liberdade supõe, ao mesmo tempo, a capacidade cerebral ou intelectual de conceber e fazer escolhas, e a possibilidade de operar essas escolhas dentro do meio exterior. Sem dúvida há casos em que se pode perder toda a liberdade exterior, estar numa prisão, mas conserva a liberdade intelectual. (MORIN, 2006, p. 126)
\end{abstract}

Morin (2006) vai mais além, no que diz respeito à elucidação do que seja autonomia, trazendo o conceito no âmago da discussão sobre territorialidade, na perspectiva da teoria da complexidade, ao afirmar que:

a noção de autonomia humana é complexa já que ela depende de condições culturais e sociais. (...) Portanto, esta autonomia se alimenta de dependência; nós dependemos de uma educação, de uma linguagem, de uma cultura, de uma sociedade, dependemos claro de um cérebro, ele mesmo produto de um programa genético. (MORIN, 2006, p. 66)

Corroborando essa assertiva, Lima (2011, p. 10), conclui que "fica explícita a relação humana contida na ideia prática da autonomia, pois somos autônomos numa relação de exterioridade". Desta forma, para o autor, autonomia e heteronomia dialogam, sobretudo no âmbito sociopolítico, visto que "o outro desempenha na sociedade humana um papel fundamental para a definição prática do que vem a ser chamado de vida autônoma”. Ademais, afirma que "essa autonomia da qual tratamos passa então por um duplo crivo analítico; ela é, ao mesmo tempo, um complemento contraditório da situação de dependência socialmente construída e um atributo intrínseco do sujeito social, seja ele individual ou coletivo". Neste sentido, a condição de sujeito social incorpora a "dialógica autonomia/dependência como sua própria natureza". 
Nesta perspectiva, Morin (2002, p. 118) declara que a autonomia "não é mais uma liberdade absoluta, emancipada de qualquer dependência, mas uma autonomia que depende de seu meio ambiente, seja ele biológico, cultural ou social”.

Discutindo esta abordagem de autonomia, onde, segundo Lima (2011, p. 11), se considera "o outro como legítimo, como co-protagonista de processos sistêmicos e, acima de tudo, como participante ativo da construção de um espaço-tempo social, ou seja, de um processo de territorialização no qual o sujeito é simultaneamente produtor e consumidor", Castoriadis (1992) nos alerta para o fato de que:

A autonomia não é a eliminação pura e simples do discurso do outro, e sim elaboração desse discurso, onde o outro não é material indiferente, porém conta para o conteúdo do que ele diz, que uma ação intersubjetiva é possível e que não está fadada a permanecer inútil. (CASTORIADIS, 1992, 129).

Assim, para Lima (2001), essa concepção sobre autonomia e democracia nos convida a pensar a inter-relação existente entre a construção de territórios autônomos, face à gestão democrática destes espaços, os quais são construídos socialmente por meio de práticas econômicas, políticas e culturais. Segundo o autor, nesta perspectiva,

[...] o sujeito social é, por razões óbvias, um sujeito territorializado e territorializador; esse sujeito constrói, individual ou coletivamente, territórios, para neles se reproduzir. Haja vista que esse sujeito está em relação com os demais, institui-se a intersubjetividade como pressuposto não apenas de uma mente sistêmica, mas de uma prática social sistêmica, traduzida na produção de um território, ele mesmo, dotado de uma vida sistêmica. Esse sujeito está inserido numa dada ordem social e isto faz com que ele se defina como um sujeito de direitos. [...] (LIMA, 2011, p. 12)

Partindo desse pressuposto, o território autônomo é aquele resultado de uma prática social de um sujeito que, com consciência espacial e temporal, territorializa o espaço, reivindica seus direitos e nele constrói sua história político-social. Para Lima (2011, p. 13), esse sujeito autônomo e solidário "é aquele indivíduo que elabora um projeto e é capaz de executá-lo", o que, para Adela Cortina (2010), é a medida da democracia.

Em sua obra "Desenvolvimento como liberdade", umas das mais reconhecidas abordagens da atualidade sobre a expansão da liberdade como fim e meio para o desenvolvimento, Amartya Sen (2008) nos traz sua contribuição ao conceito de autonomia, a partir da análise de que: 
O processo de desenvolvimento, quando julgado pela ampliação da liberdade humana, precisa incluir a eliminação da privação dessa pessoa. Mesmo se ela não tivesse interesse imediato em exercer a liberdade de expressão ou da participação, ainda assim seria uma privação de suas liberdades se ela não pudesse ter escolha nessas questões (SEN, 2008, p. 53).

Constata-se, então, que mesmo agora na atualidade, a noção de autonomia - que carrega em seu núcleo a concepção de liberdade - retoma hoje o sentido de participação política e social, que deu origem ao conceito, sendo uma das mais importantes medidas na avaliação do desenvolvimento. Segundo Sen (2008, p. 19), “a liberdade de participação ou dissensão política ou as oportunidades de receber educação básica, são ou não são conducentes ao desenvolvimento". Para o autor, "ter mais liberdade melhora o potencial das pessoas para cuidar de si mesmas e para influenciar o mundo, questões centrais para o processo de desenvolvimento" (Ibid. p. 33).

É nesta perspectiva da "razão avaliatória" em Sen, que Frey (2000, p. 229) também defende a ideia de que:

[...] seja nos indicadores, seja no ciclo das políticas públicas [...] a autonomia apresenta-se como dimensão a ser considerada, configurando-se, inclusive em alicerce para que países enquadrados como de baixo ou médio desenvolvimento humano alcancem patamares mais elevados.

Nesta perspectiva de liberdade e participação social, é importante destacar as contribuições da Teoria da Justiça de John Rawls, para o qual, segundo Weber (2011), todas as pessoas terão igual direito ao mais amplo sistema total de liberdades fundamentais, que seja compatível com um sistema idêntico de liberdade para todos. Na prática, o autor considera, em termos gerais, como liberdades básicas dos cidadãos, direitos de liberdade política (a eleger e ser eleito), de pensamento, de consciência, de expressão e associação, de propriedade pessoal, de proibição, de prisão arbitrária e expropriação, salvaguardados pelo estado de Direito. Entretanto, segundo Sen (2008, p. 17) "as liberdades dependem também de outros determinantes, como as disposições sociais e econômicas (por exemplo, os serviços de educação e saúde)".

Segundo Weber (2011, p. 147), na concepção política de justiça rawlsiana, partindo do pressuposto das qualidades morais das pessoas, "a autonomia se expressa na possibilidade que os cidadãos têm de 'formular, revisar e procurar concretizar uma concepção do bem e de deliberar de acordo com ela". Na visão do autor, os "cidadãos devem poder aderir aos valores 
Altemar Felberg - Autonomia e Desenvolvimento Comunitário NO/DO Campo: Contradições e Consensos no Assentamento Luís Inácio Lula da Silva, do Movimento sem Terra - MST - em Santa Cruz Cabrália - Bahia/Brasil

políticos dessa concepção de justiça por diferentes razões, que incluem suas concepções do bem”. Isso, diz ele, é “autonomia e gera estabilidade numa sociedade cooperativa”. Em suma,

\begin{abstract}
A explicitação do conceito de autonomia em Rawls nos reporta ao que ele chama de "justiça procedimental pura". Esta implica na possibilidade das partes fazerem suas escolhas no que diz respeito aos princípios de justiça sem dependerem de algum princípio de direito e justiça previamente dado. Não dependem de nenhum ponto de vista externo a sua própria posição. Isso mostra que o consenso é efetivamente construído de forma autônoma, com a adesão das doutrinas abrangentes e razoáveis. De um procedimento justo, isto é, equitativo, origina-se um resultado justo. É claro que, mais uma vez, está pressuposta a concepção normativa de pessoa, isto é, a capacidade de ter senso de justiça e desenvolvê-lo e a capacidade de ter uma concepção do bem. Sem isso não haveria autonomia e nem acordo. É a concepção normativa de pessoa que viabiliza o projeto político rawlsiano. Sem as "capacidades morais" não há exercício da autonomia e, por consequência, não haverá consenso (WEBER, 2011, p. 147).
\end{abstract}

Vimos até aqui que o conceito de autonomia foi forjado a partir da modernidade, tendo ganhado ainda mais relevância na contemporaneidade a partir do acirramento das lutas pelos direitos sociais, sobretudo, os de participação social e política.

\title{
2.1 Contexto Sócio-Histórico e Político de Desenvolvimento e Exercício da Autonomia
}

Para melhor compreender como se dá o exercício da autonomia e como surgiram os primeiros movimentos sociais autonomistas, é preciso que revisitemos a literatura básica sobre a Democracia, desde o advento do pensamento liberal.

Para Santos (2005, p. 16), a concepção, o desenvolvimento e o exercício da autonomia, num contexto histórico, se apresentam atrelados à "própria construção da noção de democracia em Rousseau (1712-1778), que, em sua obra "O Contrato Social” (1762), define liberdade ou autonomia como o princípio inspirador do pensamento democrático". A respeito dessa construção russeauniana da noção de democracia, Duriguetto (2003, p. 33) assevera:

O constructo do sistema político rousseauniano parte da necessidade da participação ativa individual no processo político de tomada de decisões. São os indivíduos que devem criar as leis que regulam suas vidas, e é na legitimidade do exercício participativo do poder que reside sua concepção de liberdade, que não é, como para os liberais, a capacidade do exercício e da satisfação dos interesses individuais. Ao contrário, liberdade é aqui entendida como um processo sóciohistórico de exercício da autonomia política e da faculdade de aperfeiçoamento das relações humanas. 
Na sua obra, Rousseau propôs que todos os homens se unissem em torno de um novo contrato social, onde se defendia a liberdade natural do indivíduo. Esta liberdade natural caracterizava-se por ações tomadas individualmente, visando atender somente a seus instintos, com o objetivo de satisfazer suas necessidades naturais. Neste estado de natureza, o homem desconsidera todas as consequências de seus atos, perante os outros, e não tem a vontade e nem a obrigação de manter-se em relações sociais. Mais uma característica do homem em seu estado natural é a sua total e ampla liberdade de escolha e disposição para colocá-la em prática, moldando a natureza a partir do princípio do mais forte, como destaca Sahd (2005, p. 101): "O homem realmente livre faz tudo que lhe agrada e convém, basta apenas deter os meios e adquirir força suficiente para realizar os seus desejos".

Os iluministas consideravam que esta liberdade natural, que advém do desejo e vontade inatos ao ser humano e que assegurava a autonomia do indivíduo perante o outro, era um assunto relativo à racionalidade científica e à vivência da própria felicidade.

Enfim, os iluministas têm confiança na razão, e nesse ponto são herdeiros de Descartes, Spinoza ou Leibniz, mas, diferentemente das concepções desses filósofos, a razão dos iluministas é aquela do empirista Locke, que analisa as ideias e as reduz todas à experiência. Deste modo, é uma razão limitada à experiência e fiscalizada por ela. Esta razão dos iluministas encontra o seu paradigma na física de Newton, que não aponta para as essências, não formula hipóteses, nem se perde em conjecturas sobre a natureza última das coisas, mas sim, a partir da experiência e em contínuo contato com ela, procura as leis do seu funcionamento e as submete à prova (Cfe. REALE, 1990).

Rousseau elaborou uma nova concepção de autonomia, de um homem que não é apenas corpo, mas também espírito, diferenciando-se, assim, dos iluministas.

Mas considerai primeiramente que, querendo formar um homem da natureza, nem por isso se trata de fazer dele um selvagem, de jogá-lo no fundo da floresta; mas que, entregue ao turbilhão social, basta que não se deixe arrastar pelas paixões nem pelas opiniões dos homens; que veja com seus olhos, que sinta com seu coração; que nenhuma autoridade o governe a não ser a própria razão (ROUSSEAU, 1995, p. 291).

A liberdade, nesse estágio, se estabelece a partir da correlação de forças entre os indivíduos. Por isso, ao perder disputas com outros, o sujeito não consegue exercê-la. Não há regras, instituições ou costumes que se sobrepõem às vontades individuais para a manutenção do 'bem coletivo'. No entanto, na visão de Rousseau (1995), o homem selvagem viveria isolado, então não faz sentido pensar em um bem coletivo, assim como não haveria tendência 
ao conflito entre os indivíduos isolados, quando se encontrassem, já que suas necessidades seriam satisfeitas com pouco esforço, devido à relação de comunhão com a natureza. $\mathrm{O}$ isolamento entre os indivíduos só seria quebrado para fins de reprodução, uma vez que, sendo autossuficientes, não tinham outra necessidade para viverem em agrupamentos humanos. As qualidades como amor de si mesmo e a piedade foram adquiridas pelo homem, no isolamento.

Para Rousseau (1995), o homem se completa com a natureza. Assim, não é um estado a ser superado, como Locke e Hobbes acreditavam e defendiam. Rousseau assevera que "a maioria de nossos males é obra nossa e os teríamos evitado quase todos conservando a maneira de viver simples, uniforme e solitária que nos era prescrita pela natureza" (ROUSSEAU apud LEOPOLDI, 2002, p. 160).

No estado selvagem, natural, a consciência não faz distinção entre bem ou mal, já que tal distinção é característica e resultado da vida em sociedade. Segundo Rousseau (1995), o que faz o indivíduo em estado de natureza parecer bom é porque ele consegue satisfazer suas próprias necessidades sem a necessidade de estabelecer conflitos com outros indivíduos, sem a vivência de processos de opressão e escravização, simplesmente porque não sente vontade de impor a sua força a outros, para sobreviver e ser feliz.

Para este autor, o mal humano não poderia ser compensado pelo aumento do conhecimento, pela expansão das capacidades de crítica e reflexão. Ele resgata a noção de Santo Agostinho, de que o homem pode ter 'dois amores', duas orientações básicas da vontade. $\mathrm{O}$ amor de si mesmo é o sentimento naturalmente bom, inato à natureza humana, enquanto que o amor-próprio é o sentimento de paixões "repulsivas", que surgem com a vida em sociedade. Assim, a socialização e o aumento do amor-próprio leva o homem à alienação, porque passa a comparar-se com os demais e perde a busca de viver bem consigo mesmo. Rousseau "não pode aceitar a noção naturalista do Iluminismo de que o que precisamos para nos tornar melhores é de mais razão, mais cultura, mais lumières” (Idem, p. 459).

Ainda de acordo com o autor, o progresso não necessariamente nos torna sujeitos melhores, nem mesmo autônomos, pelo contrário, é muito comumente acompanhado pela decadência moral. Para ele, o progresso da razão calculista é um dos indícios da corrupção. Mas essa oposição entre moralidade e progresso não deve ser interpretada no sentido primitivista. Rousseau não sustentava a volta ao estágio natural, de pré-interação com o meio social. A ideia de recuperar o contato com a natureza é apenas uma forma de escape da dependência calculista do outro, por meio da fusão entre razão e natureza. A consciência é a voz da natureza que se manifesta em um ser social que dispõe de linguagem e razão. 
Ora, é do sistema moral formado por essa dupla relação consigo mesmo e com suas relações com seus semelhantes que nasce o impulso da consciência. Conhecer o bem não é amá-lo: o homem não tem o conhecimento inato dele. Mas logo que sua razão o faz conhecer, sua consciência o leva a amá-lo: este sentimento que é inato (ROUSSEAU, 1995, p. 337-338).

Rousseau (1995) afirma que não somos individualmente autônomos, apenas o somos como membros de um tipo especial de sociedade. Quando o contrato social cria uma nova ideia de bem comum, o pensamento ativa em cada indivíduo um amor inato que permite controlar os desejos privados e agir como membros de um todo moral, o homem em estado civil. Por isso passamos a ser livres e autônomos, porque podemos romper com a escravidão dos nossos desejos e viver sob uma lei que proporcionamos a nós mesmos. No estado natural, o homem desfruta de uma liberdade natural, que é física, e não vai além de suas forças.

No contrato social, o homem renuncia a liberdade natural em favor da liberdade civil, que é circunscrita pela vontade geral. No estado civil, ele adquire a liberdade moral, já que passa a obedecer à lei que ele instituiu a si próprio, em vez de seguir o impulso.

Deste modo, o papel da educação seria de elevar a natureza do homem para além da animalidade, numa esfera onde existem leis. Inclusive, podemos afirmar que o papel da educação é tornar sociável a insociabilidade contida no amor de si mesmo e no amor-próprio. Assim, Rousseau está na origem das visões morais que fazem da liberdade autodeterminante a chave para a virtude. Entre elas, a de moralidade como autonomia, desenvolvida por Kant. Mas a concepção de autonomia de Rousseau é, para Kant, heterônoma. O pensamento kantiano defende que a lei moral não pode ser definida por qualquer ordem externa, nem pelo impulso da natureza em mim. Para que haja autonomia, a moralidade não pode estar fora da vontade racional do homem.

Para Martins (2001, p. 10), a autonomia democrática rousseauniana ocorre quando

[...] uma sociedade é capaz de dar leis a si própria, promovendo a perfeita identificação entre quem dá e quem recebe uma regra de conduta, eliminando, dessa forma, a tradicional distinção entre governados $\mathrm{e}$ governantes, sobre a qual se fundou todo o pensamento político moderno.

Além de Rousseau, vários outros pensadores, a exemplo de Thomas Hobbes, John Locke e Charles Louis de Secondat, influenciaram decisivamente na formação do pensamento liberal, o que, de certa forma, deu origem às primeiras discussões sobre a autonomia democrática dos sujeitos. Tomados separadamente, o pensamento de cada um desses autores é bastante singular e, em muitos pontos, até divergente. Todavia, conjuntamente, suas ideias, 
Altemar Felberg - Autonomia e Desenvolvimento Comunitário NO/DO Campo: Contradições e Consensos no Assentamento Luís Inácio Lula da Silva, do Movimento sem Terra - MST - em Santa Cruz Cabrália - Bahia/Brasil

incluindo as de Rousseau, fundaram o liberalismo - doutrina política que influenciou decisivamente as sociedades ocidentais, do final do século XVIII até os dias de hoje.

O ponto de convergência entre estes era que os indivíduos abririam mão de sua liberdade individual para viver em sociedade, se quisessem proteger seus bens e suas vidas.

\begin{abstract}
A maneira única em virtude da qual uma pessoa qualquer renuncia à liberdade natural e se reveste dos laços da sociedade civil consiste em concordar com outras pessoas em juntar-se e unir-se em comunidade para viverem em segurança, conforto e paz umas com as outras, gozando garantidamente das propriedades que tiverem e desfrutando de maior proteção contra quem quer que não faça parte dela. Qualquer número de homens pode fazê-lo, porque não prejudica a liberdade dos demais; ficam como estavam no estado de natureza (LOCKE, 1983, p. 71).
\end{abstract}

Dessa forma, pode-se constatar que o ponto de partida da construção histórica do exercício da autonomia se deu praticamente no mesmo momento em que ocorreu a transição do estado de natureza - onde a condição humana era de plena liberdade e independência, não existindo nem 'bem' nem 'mal', nem 'certo' ou 'errado', nem a noção de 'justo' ou 'injusto' para o pensamento liberal que deu origem ao Estado de Direito e uma nova ordem política. "De acordo com o pensamento liberal, todos os indivíduos são iguais por natureza e igualmente portadores de direitos naturais aos quais eles não podem, em hipótese alguma abdicar: os direitos à liberdade e à propriedade" (COELHO, 2009, p. 32).

Todavia, neste contexto, Bobbio (2000) assinala que, para o bom funcionamento da democracia, não basta que a maioria participe, direta ou indiretamente, da tomada de decisões coletivas, nem mesmo a existência de regras de procedimento inânimes. Se assim fosse, "a democracia será jamais a melhor forma de governo a não ser que possa ser organizada de maneira a não permitir, que nenhuma classe, nem mesmo a mais numerosa, possa reduzir todo o resto à insignificância política" (MILL, 1980, p. 87).

Para Bobbio (2000, p. 32), torna-se “indispensável uma terceira condição: é preciso que aqueles que são chamados a decidir ou a eleger os que deverão decidir sejam colocados diante de alternativas reais e postos em condição de poder escolher entre uma e outra". No entanto, para que esta condição seja efetivamente atendida, é de fundamental importância que sejam garantidos - àqueles que foram chamados a decidir - os denominados direitos:

[...] de liberdade de opinião, de expressão das próprias opiniões, de reunião, de associação [...], os direitos à base dos quais nasceu o Estado liberal e foi construída a doutrina do Estado de direito no sentido forte, isto é, do Estado que não apenas exerce "sub lege", mas o exerce dentro de limites derivados do reconhecimento constitucional dos direitos "invioláveis" do indivíduo (BOBBIO, 2000, p. 32). 
Nesta perspectiva dos direitos individuais, segundo Coelho (2009):

Por se tratar de direitos humanos inalienáveis, a preservação da liberdade e da propriedade dos indivíduos seria considerada pelos liberais como cláusula pétrea de qualquer contrato social. Toda ameaça ou tentativa de usurpação desses direitos seria sempre espúria, pois contrária à razão da existência do próprio Estado (COELHO, 2009, p. 35).

Ainda segundo o pensamento político de Bobbio, entre a realidade concreta e os nobres ideais que foram preconizados pelo liberalismo, e desde sua instituição na sociedade, um longo e complexo processo de transformações sociais, históricas e econômicas mudou os mecanismos de funcionamento da democracia burguesa, acrescentando-lhe diferentes propriedades.

Foi assim que a concepção individualista que lhe deu origem, contrariando a concepção orgânica de sociedade prevalecente nas organizações sociais da Antiguidade e da Idade Média, baseada no princípio do indivíduo soberano que, de acordo com outros indivíduos soberanos, criaria a sociedade política num regime sem intermediários, confrontou-se com uma realidade de organizações, grupos, associações, sindicatos, interesses partidários de uma sociedade, ao final, burocratizada (COELHO, 2009, p. 35).

Assim, a figura do individuo soberano, como agente político, cede lugar aos grupos organizados, atuantes numa sociedade democrática. De acordo com Bobbio (2000, p. 35), grupos "contrapostos e concorrentes, com a sua relativa autonomia diante do governo central (autonomia que os indivíduos singulares perderam ou só tiveram num modelo ideal de governo democrático sempre desmentido pelos fatos)".

Para Martins (2001, p. 11), a discussão contemporânea sobre a ressignificação dos direitos individuais, particularmente após a década de 80 do século XXI, remete à discussão de Castel (1998), sobre a 'reinstauração do individualismo negativo prevalecente nas sociedades pré-capitalistas', exigindo, na visão da autora, "uma reflexão sobre os novos significados conferidos ao conceito de autonomia".

Nessa perspectiva, o debate sobre as transformações das sociedades democráticas e de seus mecanismos de funcionamento resvala do tema da participação social e política de indivíduos, para a complexidade que envolve a questão da distribuição e desconcentração do poder nessas sociedades, isto é, a representação.

Assim, 
[...] o tema da representação política como elemento fundante de relações democráticas tem permeado o debate acadêmico e as lutas de trabalhadores e de estudantes, cuja preocupação central sempre foi a de aperfeiçoar a democracia, ou a de romper com ela, buscando nas ideias socialistas inspiração para movimentos denominados autonomistas e/ou participacionistas (MARTINS, 2002, p. 209).

Sobre o sistema democrático, Coelho (2009, p. 66) alerta que, "ao invés de conceber a democracia como um sistema, por meio do qual o povo delibera sobre questões de interesse coletivo", Joseph Schumpeter (1883-1950), em sua análise sobre o capitalismo contemporâneo, descreveu-a de forma pessimista (talvez realista), como

Um sistema de competição entre elites que disputam o voto popular com o objetivo de exercer as funções de governo, e de seleção dos governantes entre as elites por via eleitoral. Por essa razão, a concepção de democracia de Schumpeter é também conhecida como teoria elitista da democracia (COELHO, 2009, p. 66).

No que diz respeito ao aperfeiçoamento e avaliação da democracia, preocupação central dos movimentos sociais participacionistas, Sen (2008, p. 185) argumenta que:

Desenvolver e fortalecer um sistema democrático é um componente essencial do processo de desenvolvimento. A importância da democracia reside [...] em três virtudes distintas: (1) sua importância intrínseca, (2) suas contribuições instrumentais e (3) seu papel construtivo na criação de valores e normas. Nenhuma avaliação da forma de governo democrático pode ser completa sem considerar cada uma dessas virtudes.

Vale lembrar que foi por meio do princípio da representação, consolidando a soberania popular, que a democracia começou a ganhar lugar nos Estados liberais, na virada do século XIX para o XX.

Inicialmente, liberalismo e democracia eram vistos como princípios inconciliáveis. [...] de acordo com o liberalismo todo indivíduo é portador de direitos irrevogáveis, que devem ser respeitados por qualquer governo: seja o governo de um só, de poucos ou de muitos. Já a democracia, desde a Antiguidade, repousa, pura e simplesmente, no princípio do governo da maioria, que desconhece qualquer limite além da vontade desta (COELHO, 2009, p. 37).

No bojo dessas discussões, sobre a concepção da democracia por meio da representação, Bobbio (2000) destaca a necessidade de transformá-la em democracia direta. Para o autor, essa ideia, influenciada e modificada por diferentes inspirações ideológicas e partidárias da época, vem, ao longo da história, fundamentando os movimentos autonomistas 
Altemar Felberg - Autonomia e Desenvolvimento Comunitário NO/DO Campo: Contradições e Consensos no Assentamento Luís Inácio Lula da Silva, do Movimento sem Terra - MST - em Santa Cruz Cabrália - Bahia/Brasil

de modo geral, bem como as teorias que os discutem, desde a Comuna de Paris ${ }^{20}$, tornandose, assim, um marco recente da história política mundial.

Neste sentido, na visão de Martins (2002), seja no ambiente político ou no ambiente das organizações e movimentos organizados, a participação direta de atores em processos de decisão tem sido condicionada pelo contexto sócio-histórico que configura os mecanismos de funcionamento desses processos. A autora acrescenta, ainda, que, segundo Motta (1984), atores que convivem e vivenciam cenários de liderança autoritária poderão apresentar um maior grau de dificuldade em expressar suas ideias e colocar suas opiniões no grupo, o qual, por sua vez, irá refletir, também, no movimento pessoal de criar e mobilizar esforços físicos e emocionais, a favor de um empreendimento coletivo.

Por outro lado, segundo Bobbio (2000), se é dada ao indivíduo a possibilidade de ampla participação direta em processos decisórios institucionais, proporcionada, sobretudo, pelo advento da sociedade informatizada, isso pode gerar um fenômeno inverso e positivo, que é o da apatia pela participação política e social.

Sobre esta questão, Sen (2000, p. 168) destaca que:

Os indivíduos vivem e atuam em um mundo de instituições. Nossas oportunidades e perspectivas dependem crucialmente de que instituições existem e do modo como elas funcionam. Não só as instituições contribuem para nossas liberdades, como também seus papéis podem ser sensivelmente avaliados à luz de suas contribuições para nossa liberdade. Ver o desenvolvimento como liberdade nos dá uma perspectiva na qual a avaliação institucional pode ocorrer sistematicamente.

Neste contexto, Martins (2002) assinala que os processos de participação política e social são constituídos por uma dinâmica individual e coletiva própria, que opera concomitantemente. Para ela,

Se a necessidade de participação é o desejo que move o ator a praticar a ação, o sentido de sua participação num empreendimento coletivo pode ser altamente positivo. Se, ao contrário, a participação é delegada por normas, vigora a ausência do desejo como motor fundante da ação (MARTINS, 2002, p. 210).

\footnotetext{
${ }^{20}$ A Comuna de Paris, de 1871, foi a primeira experiência de governo proletário da História. Mesmo ocorrida há 140 anos, ela continua atual, e seu estudo e conhecimento, associados aos de outras revoluções, contribuem para desnudar conhecidas e velhas falácias de fim da história. A experiência da Comuna de Paris permite ao proletariado compreender que não só é possível, mas é um dever fundamental e um direito lutar por seus ideais de liberdade, igualdade e fraternidade, que continuam presentes e é a seiva que levará à construção de uma nova sociedade, conforme assegura COSTA (2011, p. 16).
} 
Para a autora, neste último caso, esta pseudoparticipação do sujeito dificilmente imprimirá o mesmo sentido em ações de natureza social e a empreendimentos coletivos que buscam a mudança. Nessa perspectiva, “os movimentos autônomos e/ou participativos constituem o amplo cenário político e social que alimenta o antagonismo que fundamenta as relações sociais por força do desejo de mudanças, imprimidas pelas classes trabalhadoras". (MARTINS, 2002, p. 210).

Mundialmente, no âmbito social e político, foi justamente em meio a um cenário pujante de luta dos movimentos participacionistas e movimentos autonomistas, de modo geral, que a autonomia, segundo Martins (2001), emergiu no final do século XIX e no início do século XX, na perspectiva da autogestão, particularmente na Comuna de Paris (1871), transformando-se na bandeira de luta de diferentes movimentos operários autogestionários, dentre os quais se pode destacar:

[...] a formação dos comitês de fábrica quando da realização da Revolução Russa (1917); as experiências de coletivização de empresas agrícolas e industriais durante a Revolução Espanhola (1936/1939); as comunidades de trabalho na França em 1945, cujo principal lema era obter a cultura e a formação no seio da empresa, considerados tão importantes quanto obter a própria remuneração; a experiência implementada pela Iugoslávia desde 1951, por iniciativa do próprio Estado e o movimento autônomo de trabalhadores na Polônia dos anos 1970; as experiências de coletivização da economia na Argélia nos anos 1960; os conselhos de fábrica da Itália nos anos 1920, quando após uma onda de greves os trabalhadores assumiram o controle das fábricas e constituíram em cada uma delas um conselho que assumiu a direção técnica e administrativa. (MARTINS, 2001, p. 27).

Em linhas gerais, ainda segundo a autora, a reivindicação pela autonomia que caracterizou movimentos como a Comuna de Paris, a Revolução Espanhola, entre 1936 e 1939, o socialismo, no caminho próprio da Iugoslávia, e o movimento sindical na Polônia, nos anos 1970, expressava o ideário dos movimentos da classe trabalhadora industrial que lutavam por uma profunda mudança na representação política dentro das organizações, com a garantia de amplo poder de participação dos funcionários, nos processos de decisão institucional. Para Martins (2002), historicamente, todos esses movimentos sociais foram e têm sido impulsionados e motivados pela mesma substância política e social que lhes é inerente, que é a garantia ao direito de liberdade política e de participação social, ampliando, por sua vez, as bases que sustentam a democracia, no que tange à representação política e, consequentemente, à distribuição e desconcentração de poder, bem como uma organização coletiva baseada no livre direito de associação de trabalhadores ou de produtores. 
No que diz respeito a estes movimentos sociais organizados, Gohn (2009, p. 49), com muita propriedade, frisa que:

As motivações para a participação ou identidade com conflitos e lutas sociais decorrem da memória de experiências morais de desrespeito, de privação de direitos que criaram fraturas morais. Os conflitos sociais provêm também de experiências divergentes ou de uma ordem natural livre de interpretações morais.

Em síntese, no âmbito político, de modo geral, o elemento de união dos mais variados e distintos movimentos sociais que eclodiram no mundo, no final do século XIX, foi a reivindicação pela autonomia, pois os atores envolvidos nestes movimentos proclamavam e lutavam pela necessidade de um redirecionamento da ação política, em torno do desiderato de uma sociedade mais justa e igualitária, assegurado o real direito à participação e usufruto do desenvolvimento.

Já no âmbito teórico, de acordo com Martins (2002), ganhavam relevância nesse período outras esferas da dinâmica social, como, por exemplo, a moral, os valores, o modo de vida e a cultura, promovendo um deslocamento da perspectiva de análise que priorizava a macroestrutura da sociedade para os problemas da vida cotidiana.

Segundo Meneses (1995, p. 42):

[...] a ligação entre democracia e autonomia, adquire, assim, um novo perfil: já não se trata de conceber a autogestão como condição da autonomia e, portanto, da democracia, mas desligando a autogestão da autonomia, desvendar sendas do sentido de, mesmo por dentro da racionalidade da representação, realizar a simbiose entre democracia e autonomia. Trata-se de questão ainda pouco explorada do pensamento político e da própria condição humana, para a qual não temos respostas conclusivas. Contudo, vale lembra que, hoje, a gestão da autonomia - agora desligada da autogestão - se repõe, num mundo onde os sujeitos agem sem liberdade de ação no espaço público, tolhidos pelo poder de manipulação de credos e ideologias, instigadores da razão preconceituosa e da opinião sem julgamento.

No Brasil, reconhecidamente, os grandes movimentos sociais se originaram dos conflitos que se acirraram em torno da luta pelo uso e ocupação da terra e contra os processos opressores marcados pela exploração, dominação e degradação dos povos colonizados povos que sofreram não só as violências físicas do período colonial, a exemplo dos genocídios e escravidão, mas, sobretudo, as violências simbólicas do período pós-colonial, como a negação dos direitos sociais e trabalhistas e a discriminação étnico-racial.

Para Freire (1983), o sistema colonial era majoritariamente autárquico, inviabilizando a participação popular e o autogoverno, requisitos necessários para que uma nação seja 
constituída autonomamente. "Não há autogoverno sem dialogação, daí ter sido entre nós desconhecido o autogoverno ou dele termos raras manifestações" (FREIRE, 1983, p. 70).

Dessa forma, sem abertura ao diálogo, o autocratíssimo colonial esterilizou qualquer possibilidade de participação popular na vida pública do país. Os povos indígenas, os africanos e as mulheres, em particular, eram invisíveis na sociedade e na política, ocupando espaços culturais e sociais de inferioridade. Romper com esta cultura segregacionista, ainda quase cinco séculos depois, ainda se apresenta como um grande desafio da nação, que por mais avanços que tenham alcançado, ainda deixa margens a processos de exclusão.

Neste contexto, fica evidente que o caminho percorrido pelo Brasil, contrário à consolidação da democracia, enfraqueceu o desenvolvimento de um projeto de nação autônoma, realçando a já alarmante desigualdade social e reforçando a condição de heteronomia que estes povos escravizados foram submetidos. Assim, o processo de criação do Estado Democrático aconteceu sem que fossem consideradas as especificidades sociais resultantes da colonização exploratória de Portugal.

De lá para cá, um longo e complexo processo de transformações sociais, históricas e econômicas mudou os mecanismos de funcionamento da democracia, acrescentando-lhe diferentes propriedades. Em sua crítica ao sistema democrático, Noberto Bobbio (1998, p. 324) enfatiza a necessidade de se ampliar ainda mais o papel da população nos regimes sociais democráticos. Para o autor, é preciso que "a participação popular e também o controle do poder a partir de baixo se estenda" a todos os órgãos públicos e políticos. Da mesma forma, Boaventura Sousa Santos (2005) nos alerta para o perigo em se restringir a cidadania a uma cidadania civil e política, ao considerar que esta representação política precisa ser fortalecida pela comunhão de instrumentos participativos mais eficazes, se quisermos alcançar o que o mesmo chama de "democracia pós-moderna".

Numa crítica ainda mais profunda, Dagnino (2005) reflete sobre uma "confluência perversa e deslocamento de significados" sobre o que se entende por sociedade civil, participação e cidadania, propondo uma ressignificação sob a ótica da existência, inclusive no Brasil, de dois projetos políticos em disputa: um de alargamento da democracia, e outro de consolidação do modelo neoliberal.

Seja qual for a crítica, é consenso de que a participação social é estratégica para a consolidação da democracia participativa, além de determinante para o exercício da cidadania, da expressão simbólica e do desenvolvimento socioeconômico do país. 
Numa história mais recente, a democracia brasileira é, também, consequência das lutas travadas contra o autoritarismo do regime militar que eclodiu no final dos anos 60 e perdurou até o movimento pelas eleições diretas, em 1984. A valorização da democracia, da participação e da autonomia dava o tom aos movimentos sociais da época, que reivindicavam por melhorias no sistema político, diminuição das desigualdades sociais, garantia de direitos sociais básicos e, sobretudo, maior espaço de participação na vida política do país.

Como resultado destes movimentos, subsidiando o cenário de hoje, foi promulgada, em 1988, nossa sétima Constituição Federal, que ficou conhecida como a "Constituição Cidadã", pois, entre outros avanços sociais, reconheceu, em seu artigo $1^{\circ}$, que "todo poder emana do povo, que o exerce por meio de representantes eleitos ou diretamente".

Assim, seja nos períodos colonial, monárquico ou republicano, ficam evidentes os diversos processos de dominação a que o povo brasileiro foi submetido e, em oposição, seus processos de resistência, cada um com características próprias. A luta por direitos, por autonomia e por uma cidadania participativa sempre esteve no cerne das reivindicações, resultando nas conjunturas política, social e cultural, atualmente imperantes.

Segundo Meneses (1995, p. 38), em seu esboço interpretativo do pensamento político de Marilena Chaú, no período de 1978 a 1982, a questão da autonomia, no ano de 1978 "era posta no sentido de identificá-la com práticas sociais conselhistas e de autogestão". Todavia, no ano de 1982, segundo o mesmo autor, “o ideário autonomista clássico fenece e cede lugar a uma estratégia que privilegia, no lugar da autogestão, um continuum (a expressão é de Bobbio) que articula tanto a representação política como a participação direta" (MENEZES, 1995, p. 38), onde "é difícil dizer onde termina a primeira e onde começa a segunda" (BOBBIO, 1992, p. 52).

Sobre os movimentos autonomistas brasileiros, Menezes (1995, p. 38) salienta que:

Esta evolução da autonomia como autogestão para a autonomia como continuum entre práticas de democracia direta e de representação indireta, mais que um acidente histórico ou um acaso da política, na realidade, expressa tendências de racionalidade inerentes ao desenvolvimento da atividade política no espaço público do capitalismo.

Enfim, inúmeras outras experiências pontuais de luta social pela autonomia poderiam ser elencadas neste capítulo. Entretanto, dada à natureza e objetivos desta pesquisa, apenas alguns dos mais relevantes desses movimentos sociopolíticos foram abordados, pela amplitude que adquiriram e pela influência inquestionável e dimensional que exerceram sobre as relações políticas do mundo inteiro. 


\subsection{Autonomia como Medida para o Desenvolvimento}

Cronologicamente, Van Eyken (1990), Friedmann (1992), Criag e Mayo (1994) e Rowlands (1997) são exemplos de autores que aprofundaram os estudos sobre o empoderamento de um indivíduo na atualidade, e enfocaram a noção de "poder" no contexto do desenvolvimento, cada um com seu olhar e sua percepção singular acerca do assunto, interpretando-o, em momentos, de maneira contrastante, como sintetizado abaixo pelos estudiosos no assunto, Peter Oakley e Andrew Clayton (2003, p. 10):

Poder, no sentido de transformação radical e confrontação entre os que têm e os que não têm poder, como a dinâmica crucial das mudanças sociais. Esta interpretação argumenta que somente nos centralizando nos padrões de mudança existentes e aplicando-os, será possível uma mudança significativa. Poder, no sentido usado por Paulo Freire, como um aumento da conscientização e desenvolvimento de uma "faculdade crítica" entre os marginalizados e oprimidos. Este é o poder de "fazer" e de "ser capaz", bem como de sentir-se com mais capacidade e no controle das situações. Referese ao reconhecimento das capacidades de tais grupos para agir e desempenhar um papel ativo nas iniciativas de desenvolvimento. Implica superar décadas de aceitação passiva e fortalecer as habilidades de grupos marginalizados para que se envolvam como atores legítimos no desenvolvimento ${ }^{21}$.

Esses dois pontos de vista oferecem interpretações distintas sobre o significado do 'poder' e as tentativas individuais e coletivas de exercício da autonomia no contexto do desenvolvimento. Tanto aqueles que conquistaram o poder, quanto os 'desempoderados' são categorias de atores fundamentais para a compreensão de como se dá o desenvolvimento.

Ainda segundo estes autores, o poder pode ser visto como um bem de propriedade do Estado ou de uma classe dominante, que o exerce para manter o controle, alienar e afirmar sua autoridade. Também se manifesta nos interesses dicotômicos e irreconciliáveis de diferentes classes e grupos em um contexto determinado. Por exemplo, nos padrões locais ou regionais, no poder que os homens frequentemente exercem sobre as mulheres, no poder que empregadores exercem sobre seus empregados e no poder que as instituições exercem sobre as pessoas.

Nesta perspectiva, Carla Lyra (2005) nos diz que uma das estratégias para o desenvolvimento e sua avaliação é a importância e valorização da participação e da autonomia dos indivíduos, transformando-os em sujeitos de ação, o que pode ser entendido como a busca de um maior grau de conscientização e interferência no processo de dinamização

${ }^{21}$ Grifos do autor.

Universidade Lusófona de Humanidades e Tecnologias -FCSEA- Instituto de Educação 
socioeconômica, através da ação da sociedade civil organizada. Entretanto, a questão da representatividade e da democracia nos tempos atuais - que abarcam as noções de sociedade civil, participação e cidadania - é polêmica e assume facetas variadas, com uma "confluência perversa e deslocamento de significados”, conforme argumenta Dagnino (2005, p. 50).

Especialmente no Brasil, este processo de re-significação deve ser analisado sob a ótica da existência de dois projetos políticos em disputa: um de alargamento da democracia e outro de consolidação do modelo neoliberal produzido pelo Conselho de Washington. Analisados conjuntamente - daí a confluência perversa, pelo esvaziamento e expropriação de discursos -, trazemos para elucidação deste capítulo, as reflexões da autora, sobre as noções de sociedade civil, participação e cidadania, por considerar que:

As noções de sociedade civil, participação e cidadania mantêm entre si uma estreita relação e foram selecionadas porque são, da nossa perspectiva, elementos centrais desse deslocamento de sentidos que constitui o mecanismo privilegiado na disputa política que se trava hoje ao redor do desenho democrático da sociedade brasileira. (DAGNINO, 2006, p. 51-52)

No contexto brasileiro, o primeiro ponto de reflexão proposto pela autora diz respeito a uma representatividade cada vez menos genuína e legítima, por parte dos atores da sociedade civil "com o crescente abandono de vínculos orgânicos com os movimentos sociais que as caracterizava em períodos anteriores" (DAGNINO, 2006, p. 53). Muitas ONGs, por mais que expressem interesses difusos na sociedade e sejam bem intencionadas, são conduzidas a se associarem a projetos políticos contrários à democracia; em alguns casos, mais como uma estratégia de sustentabilidade institucional, uma vez que o Estado, temendo o diálogo com movimentos sociais mais extremistas, prefere privilegiar parceiros mais "confiáveis".

A segunda reflexão diz respeito ao princípio da participação, hoje aparentemente restrita a uma participação privatista, despida de significado político e coletivo. A prática que se percebe é a participação dos setores da sociedade civil, apenas na discussão e formulação das políticas públicas. E isso demonstra, claramente, que estão excluídos dos processos estratégicos de decisão.

A última reflexão trata da noção da cidadania, que construída na luta por direitos humanos, durante a resistência à ditadura militar, buscava alcançar profundas transformações sociais, impondo um laço constitutivo entre cultura e política. 
O processo de construção de cidadania como afirmação e reconhecimento de direitos é, especialmente na sociedade brasileira, um processo de transformação de práticas arraigadas na sociedade como um todo, cujo significado está longe de ficar limitado à aquisição formal e legal de um conjunto de direitos e, portanto, ao sistema político-jurídico. A nova cidadania é um projeto para uma nova sociabilidade: não somente a incorporação no sistema político em sentido estrito, mas um formato mais igualitário de relações sociais em todos os níveis, inclusive novas regras para viver em sociedade [...] (DAGNINO, 2006, p. 56)

No bojo dessas discussões, Boaventura de Sousa Santos (2005) sugere a instauração efetiva do que ele chama de "democracia pós-moderna", em que deve haver um maior diálogo entre governos e sociedade civil, por meio da articulação de instâncias e mecanismos de participação social em arenas públicas. Neste sentido, "a participação é estratégica para construir a possibilidade de uma democracia efetiva, que represente os interesses do conjunto da sociedade e que seja um espaço de tolerância e de reconhecimento" (FÓRUM NACIONAL DE PARTICIPAÇÃO POPULAR, 2006, p. 4).

Assim, diante da formação da sociedade brasileira, que foi constituída com base em práticas autoritárias, violentas e opressoras, com processos que perduram até os tempos atuais, faz-se necessário que a autonomia seja levada em consideração na avaliação do desenvolvimento humano, no intuito de retratar, com maior fidedignidade, as demandas que compõem a questão social no Brasil.

Como destacado por Raworth (2002 apud Pereira, 2007), deve-se considerar que a autonomia tem sido alvo de análises sobre questões desenvolvimentistas, sendo constantemente considerada como uma das mais importantes variáveis para aferição do índice de desenvolvimento, uma vez defendida por Pereira, M. (2007, p. 4) como um "recurso capaz de livrar os indivíduos não só da opressão sobre as suas liberdades (de escolha e de ação), mas também da miséria e do desamparo".

Ainda para o autor, a dimensão da autonomia apresenta relevância crucial quando se nota que na formação da sociedade de nosso país não tem sido verificado o interesse das classes dominantes, em mobilizar esforços no sentido de ampliar as condições que favoreçam o desenvolvimento da autonomia das classes marginalizadas. Ao contrário, houve e ainda existe, como bem destaca Fernandes (2006), certa preocupação das elites com a manutenção do seu poder, fazendo, para tanto, o uso de práticas autoritárias e de cooptação, que por consequência acabam por impedir ou até mesmo elidir as possibilidades de desenvolvimento de atitudes autônomas por parte das classes menos abastadas. 
Classificada por Fernandes (2006) como a 'classe fragmentada', a burguesia brasileira, historicamente não dispunha de vontade política e interesse para a superação de graves problemas, em setores da economia, que afetavam o proletariado.

Segundo Pereira, M. (2007), além da notável falta de desinteresse da burguesia em promover e afirmar a autonomia como uma das características da formação identitária da sociedade brasileira, nota-se que esta mesma classe tem feito o possível para manter a tradição de dominação, inclusive da violência, nas instituições, por meio da cooptação. E é por conta deste comportamento excludente que a democracia brasileira é denominada por Fernandes (2006) como a "democracia da cooptação", que serve apenas a interesses elitistas, reduzindo cada vez mais a possibilidade de um fazer autônomo dos demais estratos da sociedade brasileira, minimizando, por sua vez, os espaços democráticos que possibilitam o exercício da liberdade política e de participação.

Com base nesta assertiva, é que, para o mesmo autor, a autonomia como indicador primordial, na medida do desenvolvimento, deveria considerar dimensões relacionadas à liberdade de associação, por exemplo, o que não se apresenta de difícil medição, pois poderia ser identificado por meio da "quantidade de associações sem fins lucrativos criadas ao longo dos anos com finalidades vinculadas ao atendimento das demandas sociais ou de lutas por direitos" (PEREIRA, M., 2007, p. 5).

Para o autor, mesmo reconhecendo que existem índices profícuos na avaliação do desenvolvimento, como o Índice de Desenvolvimento Humano (IDH), por exemplo, que traz em sua matriz variáveis além do aumento da renda, é urgente envidar esforços no sentido de configurar índices mais próximos da realidade brasileira, que levem em consideração o aumento da capacidade das pessoas, seu poder de fazer escolhas por si mesmas e de concretizá-las. De acordo Pereira, M., (2007), a falta da autonomia como indicador a ser considerado, tem dificultado o desenvolvimento humano em todas as suas potencialidades.

Visando subsidiar a compreensão da autonomia como indicador de desenvolvimento comunitário local, trazemos o resultado de uma pesquisa de estágio de doutoramento, realizada em Portugal, por Rover (2005, p. 2), que objetivou, primordialmente, analisar em que "medida a autonomia local na definição de estratégias e projetos é positiva aos territórios locais, ou apenas favorece alguns atores destes territórios, com poucos resultados positivos a grupos mais necessitados e desorganizados", no âmbito do Programa de Iniciativa Comunitária: Ligação Entre Ações de Desenvolvimento da Economia Rural (PIC LEADER). 
Segundo o autor, a implantação do Programa LEADER teve início no início da década de 90, e foi concebido para ser aplicado a "regiões essencialmente rurais" (OCDE, 1994), cuja base da economia se caracterizasse pela agricultura familiar, onde vários indicadores de desenvolvimento apresentassem índices bem abaixo dos identificados nas regiões urbanas do país; áreas que poderiam ser classificadas como "regiões ou territórios desfavorecidos" (ROVER; HENRIQUES, 2005, p. 8). Conforme o estudo, o Programa chegou a abranger 89\% dos territórios rurais portugueses.

$\mathrm{O}$ estudo aponta que a receptividade dos atores locais ao Programa LEADER deu-se em virtude da sua "capacidade de mobilização e inovação, permitindo a emergência de novos laços sociais e formas de organização local” (THIRION; CAVACO, s/d, apud ROVER; HENRIQUES, 2005, p. 9), avaliado não mais como uma aposta, mas como "um acerto em termos de política pública de desenvolvimento rural" (ROVER; HENRIQUES, 2005, p. 3), que responde de forma eficaz às demandas da própria comunidade, de dentro para fora.

O resultado da pesquisa, dentre outros, indica que:

[...] A construção de um desenvolvimento local com autonomia passa também pela identificação de necessidades e interesses comuns entre diferentes atores socioeconomicamente fragilizados e sua organização para satisfação destas necessidades e interesses (ROVER; HENRIQUES, 2005, p. $16)$.

Em suas avaliações, os autores da pesquisa enfatizam que "através de uma participação decisória e integrada de amplos contingentes da população local é possível aproveitar o saber-fazer, o conhecimento detalhado da realidade e a vontade de agir dos atores sociais locais" (ROVER; HENRIQUES, 2005, p. 12). Destacam, entretanto, que esta participação não deve ficar restrita aos indivíduos que possuem "maior poder relacional", mas que deve contemplar, principalmente, aqueles mais necessitados, evitando, desta forma, a "reprodução das assimetrias de poder".

\subsection{Sentido da Autonomia para Moradores do Assentamento Luís Inácio Lula da Silva}

A partir do entendimento de que a autonomia pode ser definida como a capacidade de conceber e fazer suas próprias escolhas, tratando-se de uma condição a ser conquistada individualmente pela independência da vontade e pela liberdade de ação, apresentamos, a seguir, o sentido dessa autonomia para os homens e as mulheres trabalhadores/as rurais semterra, sujeitos desta pesquisa, através dos seguintes gráficos: 
Altemar Felberg - Autonomia e Desenvolvimento Comunitário NO/DO Campo: Contradições e Consensos no Assentamento Luís Inácio Lula da Silva, do Movimento sem Terra - MST - em Santa Cruz Cabrália - Bahia/Brasil

\section{Gráfico 03 - Sentido da autonomia para as mulheres - capacidade de conceber e fazer suas próprias escolhas}

2.1.1. Vai aonde quer sem ter que pedir autorizaçào a ninguem?

2.1.2. Vive da maneira como quer, como acha melhor?

2.1.3. Realiza trabalhos domésticos quando tem vontade?

2.1.4. Decide sozinho(a) sobre como se vestir?

2.1.5. Visita seus amigos e familiares quandotem vontade?

2.1.6. Decide onde e com o que trabalhar?

2.1.7. Decide como gastar/investir o dinheiro que ganha?

2.1.8. Decide estudar o curso que quer, aquele que deseja?

2.1.9. Respeita/segue somente as regras que julga necessário?

2.1.10. Faz o que é da sua vontade?

2.1.11. Tem ideias e opiniōes proprias? Nāo deixa que outros falem por você?

2.1.12. Dà suas opiniōes sem se preocupar com que os outros irăo pensar?

2.1.13. Decide como utilizar seu tempo de lazer da maneira que deseja?

2.1.14. Descansa e relaxa quando está cansado(a), sem precisar de permissão?

2.1.15. Exprime suas emoçōes livremente, sem medo de criticas?

- NUNCA, fora de cogitaçăo

NÄO, mas isso està mudando

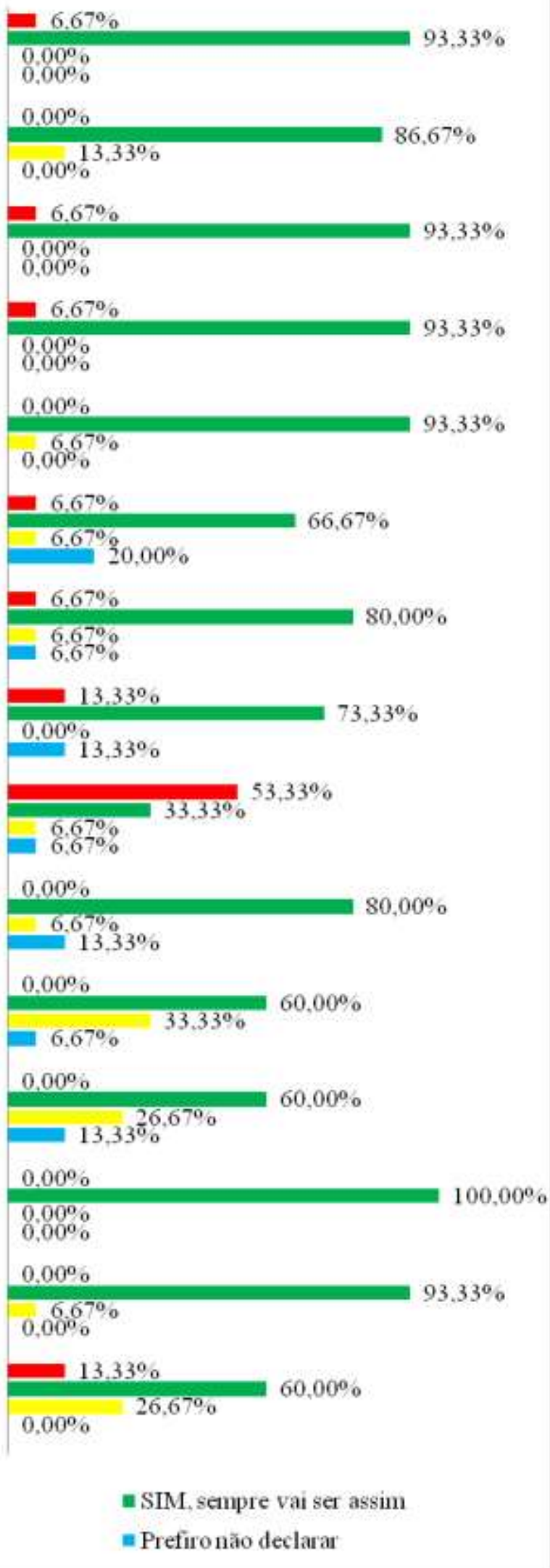


Analisando o gráfico, percebe-se que a autonomia individual das mulheres - traduzida na capacidade destas, de conceber e fazer suas próprias escolhas - é bastante significativa, registrando-se uma alta porcentagem, entre $86,67 \%$ e $100 \%$, que demonstram decidir autonomamente sobre questões do âmbito da vida privada, considerando-se o representado nas questões que tratam da liberdade e poder de decisão de ir e vir (2.1.1), de levar a vida conforme seus próprios preceitos (2.1.2), de realizar trabalhos domésticos por vontade própria (2.1.3), de como se vestir (2.1.4), de visitar amigos quando sente vontade (2.1.5), de como utilizar o tempo livre (2.1.13) e de /relaxar quando sente vontade (2.1.14). Todavia, se analisarmos as questões que se relacionam à vida coletiva, a exemplo das questões 2.1.9, 2.1.11, 2.1.12 e 2.1.15, notaremos que esta capacidade de pensar e agir autonomamente sofre interferência, especialmente no que se refere à externalização de ideias, opiniões e emoções.

Vale destacar o resultado apurado na questão 2.1 .9 , onde $53,33 \%$ descartam a possibilidade de respeitarem ou seguirem somente as regras que julgam necessárias, o que confirma a tese defendida por Morin (2002), quando este afirma que a autonomia não se trata de uma liberdade total e plena, livre de qualquer dependência e influência externa, mas uma autonomia que depende de seu meio ambiente; o que é visivelmente representado no seguinte relato de uma das assentadas, sujeito desta pesquisa:

[...] aqui tem uma regra, mas você escolhe, você é livre, ninguém vai impedir o que você vai fazer, só que aí você tem que respeitar as normas do movimento, e eu creio assim: se você quer fazer algo, não querer respeitar as normas daquele assentamento, se acontecer algo com você ou alguma coisa, a direção não tem nada a ver, porque você que escolheu a sua escolha, então você tem livre arbítrio pra fazer o que você quiser, só que tem que fazer o certo pra você poder ter o reconhecimento aqui dentro e poder desfrutar do que tem aqui no assentamento, porque tem muita coisa boa, agora basta você querer (MACAÚBA, excerto extraído do Grupo Focal $n^{\circ}$ 02, realizado em maio de 2016, p. 9).

O fato de o sujeito decidir abdicar de sua autonomia individual, a favor do bem-estar e harmonia da vida coletiva, não significa que o mesmo perdeu sua capacidade cerebral ou intelectual de conceber e fazer suas próprias escolhas, como bem explica Morin (2002), pois a pessoa dotada de liberdade, sem intervenção alheia, torna-se autônoma à medida que utiliza a liberdade com maior clareza e consciência em suas atitudes na sociedade, de acordo Kant (1974), uma vez que, no estado civil, o homem adquire uma liberdade moral, já que ele passa a obedecer a uma lei que ele instituiu a si próprio, em vez de seguir o impulso, conforme Rousseau (1973). 
Altemar Felberg - Autonomia e Desenvolvimento Comunitário NO/DO Campo: Contradições e Consensos no Assentamento Luís Inácio Lula da Silva, do Movimento sem Terra - MST - em Santa Cruz Cabrália - Bahia/Brasil

\section{Gráfico 04 - Sentido da autonomia para os homens - capacidade de conceber e fazer suas próprias escolhas}

2.1.1. Vai aonde quer sem ter que pedir autorizaçao a ninguem?

2.1.2. Vive da maneira como quer, como acha melhor?

2.1.3. Realiza trabalhos domésticos quando tem vontade?

2.1.4. Decide sozinho(a) sobre como se vestir?

2.1.5. Visita seus amigos e familiares quando tem vontade?

2.1.6. Decide onde e com o que trabalhar?

2.1.7. Decide como gastar/investir o dinheiro que ganha?

2.1.8. Decide estudar o curso que quer, aquele que deseja?

21.9. Respeita/segue somente as regras que julga necessario?

2.1.10. Faz o que è da sua vontade?

2.1.11. Tem ideias e opiniós próprias? Não deixa que outros falem por vocè?

2.1.12. Da suas opinióes sem se preocupar com que os outros irāo pensar?

2.1.13. Decide como utilizar seu tempo de lazer da maneira que deseja?

2.1.14. Descansa e relaxa quando está cansado(a), sem precisar de permissão?

2.1.15. Exprime suas emoçōes livremente, sem medo de criticas?

- NUNCA, fora de cogitaçăo

NĀO, mas isso està mudando

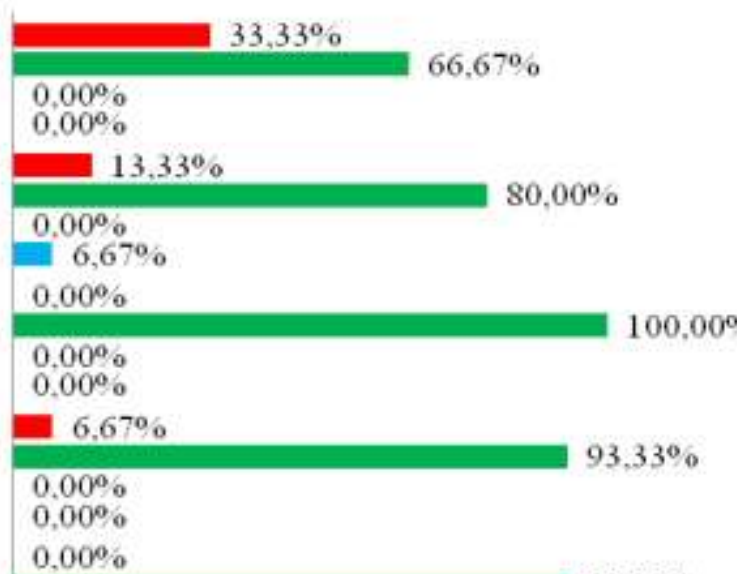

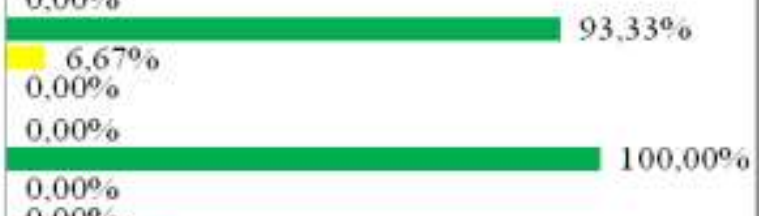

$26.67 \%$
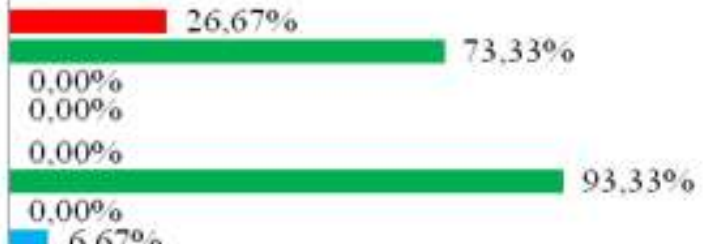

$$
6,67 \%
$$

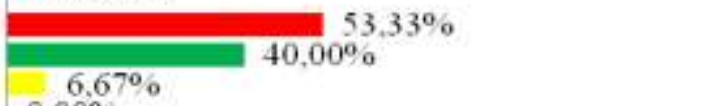

$6,67 \%$
$0.00 \%$
$13,33 \%$
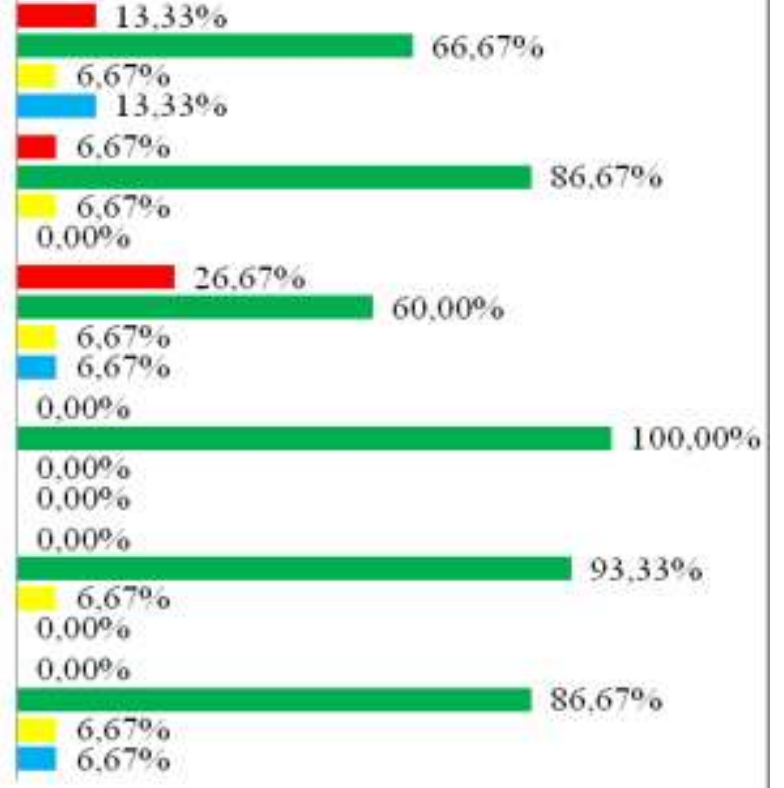

E SIM, sempre vai ser assim

= Prefiro não declarar 
Altemar Felberg - Autonomia e Desenvolvimento Comunitário NO/DO Campo: Contradições e Consensos no Assentamento Luís Inácio Lula da Silva, do Movimento sem Terra - MST - em Santa Cruz Cabrália - Bahia/Brasil

Fazendo uma análise comparativa entre o gráfico 03 (autonomia para as mulheres) e o gráfico 04 (autonomia para os homens), podemos inferir que a autonomia individual dos homens é bastante similar à das mulheres, com registro de alta porcentagem de autonomia (entre $86,67 \%$ e $100 \%$ ) para as questões relacionadas à vida privada, representado nas questões 2.1.3, 2.1.4, 2.1.5, 2.1.6, 2.1.13 e 2.1.14, já explicitadas na análise anterior, com exceção aqui para a questão relacionada à liberdade de ir e vir (2.1.1), onde 33,33\% dos homens disseram nunca sair sem autorização, e a questão relacionada à decisão de como gastar/investir a renda familiar (2.1.7), onde $26,67 \%$ afirmaram sentir a necessidade de dividir a decisão com a companheira, o que pode aqui ser justificado pelo fato de serem casados e culturalmente compartilharem as decisões da vida cotidiana com as mulheres, que no universo e população estudados, tem grande poder de decisão, conforme relatos abaixo:

A minha história veio através da minha esposa, eu não gostava do movimento, eu tinha uma imagem que o movimento era (++) não era boa a imagem do movimento. Minha esposa, ela tem alguns parentes na liderança do movimento há vinte e cinco (25), trinta (30) anos... eu comecei a namorar com ela e ela me convidava pra eu visitar, e eu falava: "eu não, você vai só, eu não vou não" (BURITI, excerto extraído do Grupo Focal no 01, realizado em maio de 2016, p.1).

Quando eu casei com minha esposa, que aí ela falou como é que era, como é que não era, aí eu passei pro acampamento Salgado, tinha uns três (3) meses que tinha fundado, daí então vamos, ela pegou e aceitou (JATAÍ, excerto extraído do Grupo Focal no 01, realizado em maio de 2016, p. 2).

[...] e nesse de dar aula voluntária que eu acabei me pegando com eles, também com os adultos, e acabei indo, isso meu esposo não queria nem saber, falou que não voltava mais... aí eu falei: "se você não quiser ir, eu vou tá indo". Eu estudava à tarde e ia de manhã, ficava lá no período da manhã, à tarde eu vinha pra escola (ARICURI, excerto extraído do Grupo Focal n ${ }^{\circ} 02$, realizado em maio de 2016, p. 2).

Nos relatos acima é retratada a influência da mulher nas decisões da vida privada, mas, sobretudo, seu papel nos processos de mobilização social e representação do MST, conquistando sua autonomia a partir de uma atuação efetiva no movimento.

Já no que diz respeito às demais questões que se relacionam à vida coletiva, à capacidade de pensar e agir conforme sua própria razão e vontade, percebe-se uma interferência, especialmente no que se refere à externalização de ideias, opiniões e emoções. $53,33 \%$ descartam a possibilidade de respeitarem ou seguirem somente as regras que julgam necessárias, comportamento já, outrora, explicado por Rousseau (1973), Kant (1974) e Morin (2002), que existe um consenso de que a vontade individual cede lugar à vontade coletiva. 


\subsection{Dimensão Social da Autonomia: percepção da vida em comunidade}

A fim de compreendermos a dimensão social da autonomia, partindo do pressuposto de que esta depende de seu meio ambiente (biológico, cultural ou social), se dando na dinâmica como o mundo evolui, como o sujeito se enxerga e se posiciona livremente diante dele, conduzindo-se à dignidade humana, apresentamos esta categoria, a seguir, a partir da análise de três (03) importantes variáveis, com recorte da questão de gênero: Trabalho e renda; Qualificação de mão-de-obra; e Participação social.

A variável Trabalho e Renda/Cadeia Produtiva/Segurança Alimentar trata de questões como: o poder para escolher sobre a atividade produtiva que deseja trabalhar individualmente; se a opinião do sujeito é levada em consideração, nos processos de produção coletiva; a liberdade do sujeito para buscar financiamento/empréstimo bancário; se a receita da venda de produtos coletivos é distribuída igualitariamente; se todos os moradores usufruem igualmente dos projetos comunitários; dentre outras.

A variável Qualificação de Mão-de-obra aborda questões relacionadas a como os processos de capacitação profissional se dão dentro da comunidade, analisando, especialmente, adequabilidade dos cursos e se há igualdade de oportunidades de acesso.

A variável Participação Social trata de compreender como o sujeito se relaciona com o MST e a comunidade, abordando questões relacionadas ao modelo de gestão dentro da área de Assentamento; à influência do MST sobre o modo de pensar, agir e viver de seus integrantes; ao compartilhamento livre e consensual de ideias e princípios; à participação em espaços públicos de discussão de políticas, dentre outras. 
Altemar Felberg - Autonomia e Desenvolvimento Comunitário NO/DO Campo: Contradições e Consensos no Assentamento Luís Inácio Lula da Silva, do Movimento sem Terra - MST - em Santa Cruz Cabrália - Bahia/Brasil

\section{Gráfico 05 - Dimensão social da autonomia para as mulheres - trabalho e renda / cadeia} produtiva / segurança alimentar

3.1.1. Tem poder para escolher sobre a atividade produtiva (agricultura, criação de animais, piscicultura etc.) que quer trabalhar individualmente?

3.1.2. Sua opinião é levada em consideraçăo quando da escolha da atividade produtiva que os moradores associados irão trabalhar coletivamente?

3.1.3. A produção agricola na comunidade sofre algum tipo de influência de instituiçóes, gupos ou movimentos sociais extemos?

3.1.4. A destinação dos produtos e forma de escoamento é decidida em grupo?

3.1.5. Você, individualmente, podebuscar financiamento/empréstimo bancário quando precisa/decide, sem depender de autorização do grupo?

3.1.6. Tendo dinheiro, você pode adquirir produtos e insumos individualmente?

3.1.7. A receita da venda de produtos coletivos é distribuida igualitariamente?

3.1.8. Você paga percentual à Associaçăo sobre sua produçāo individual?

3.1.9. As máquinas e equipamentos coletivos the servem quando você precisa?

3.1.10. Todos os moradores usufiuem igualmente dos projetos comunitários?

- NUNCA, fora de cogitação

NĀO, mas isso está mudando
$6,67 \%$

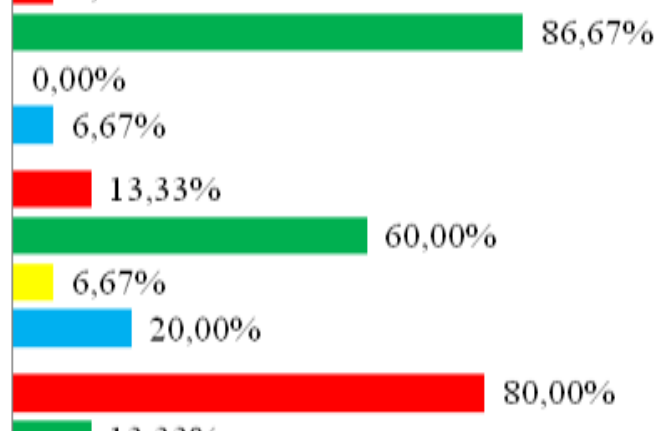

$100,00 \%$

\section{$0,00 \%$}

$0,00 \%$

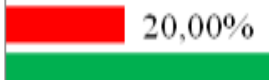

$46,67 \%$

$13,33 \%$

$20,00 \%$

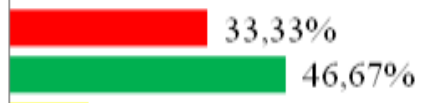

$13,33 \%$

$6,67 \%$

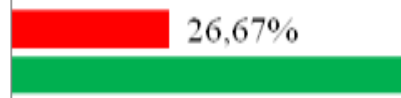

$66,67 \%$

\section{$0,00 \%$}

$6,67 \%$

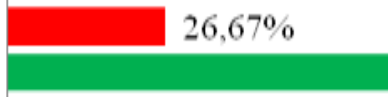

$6,67 \%$

$0,00 \%$

- SIM, sempre vai ser assim

Prefiro năo declara 
Altemar Felberg - Autonomia e Desenvolvimento Comunitário NO/DO Campo: Contradições e Consensos no Assentamento Luís Inácio Lula da Silva, do Movimento sem Terra - MST - em Santa Cruz Cabrália - Bahia/Brasil

\section{Gráfico 06 - Dimensão social da autonomia para os homens - trabalho e renda / cadeia produtiva / segurança alimentar}

3.1.1. Tem poder para escolher sobre a atividade produtiva (agricultura, criaçào de animais, piscicultura etc.) que quer trabalhar individualmente?

3.1.2. Sua opinião é levada em consideraçăo quando da escolha da atividade produtiva que os moradores associados irāo trabalhar coletivamente?

3.1.3. A produçào agricola na comunidade sofre algum tipo de influència de instituiçŏes, grupos ou movimentos sociais extemos?

\subsubsection{A destinação dos produtos e forma de} escoamento é decidida em gupo?

3.1.5. Você, individualmente, podebuscar financiamento/empréstimo bancário quando precisa/decide, sem depender de autorização do grupo?

3.1.6. Tendo dinheiro, você pode adquirir produtos e insumos individualmente? 3.1.7. A receita da venda de produtos coletivos é
distribuida igualitariamente?

3.1.8. Você paga percentual à Associação sobre sua produçāo individual?

3.1.9. As maquinas e equipamentos coletivos the servem quando você precisa?

3.1.10. Todos os moradores usufuem igualmente dos projetos comunitários?

- NUNCA, fora de cogitaçào

$\mathrm{NA} \mathrm{O}$, mas isso està mudando

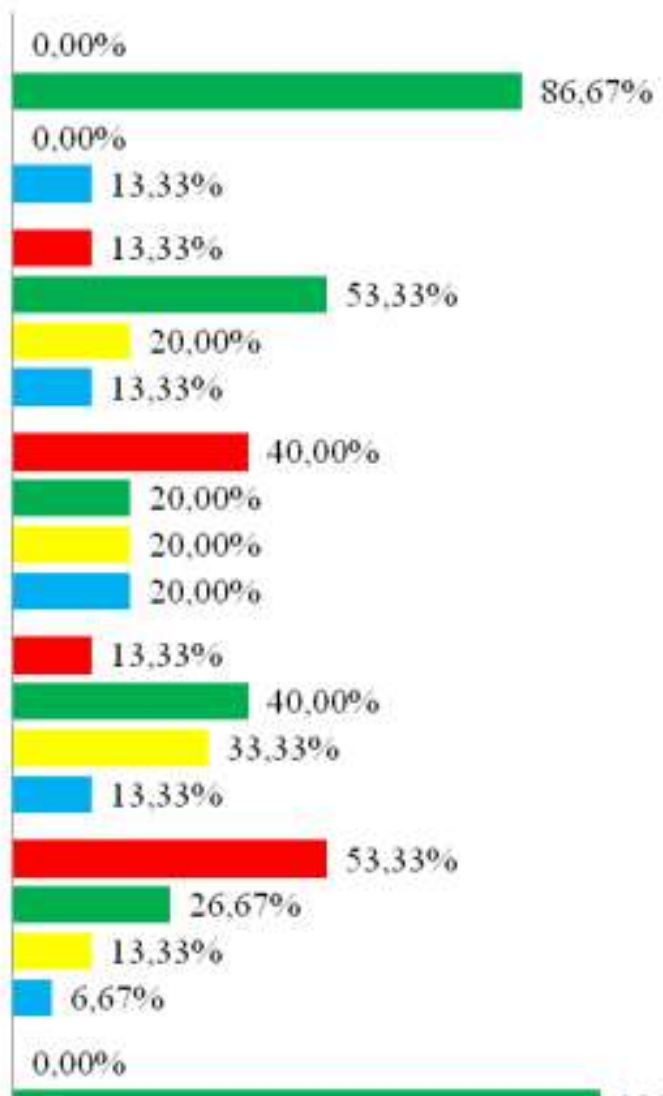

$\begin{array}{ll}0.00 \% & 100.00 \% \\ 0.00 \% & \end{array}$

\section{$26.67 \%$}
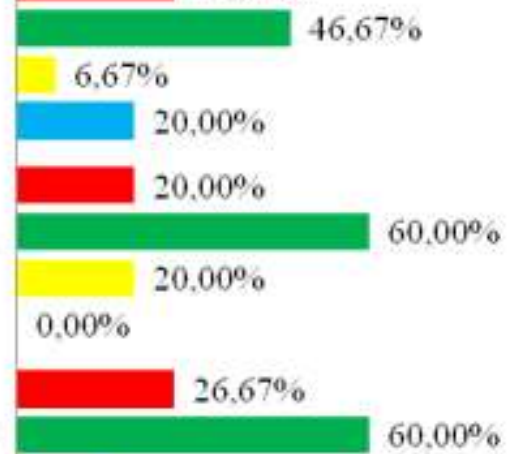

\section{$13,33 \%$}

$0,00 \%$

$6,67 \%$

$80.00 \%$

\section{$0.00 \%$}

$13.33 \%$
= SIM, sempre vai ser assim

= Prefironão declarar 
No que se refere à autonomia relacionada à variável trabalho e renda, o destaque aqui é para as questões relacionadas ao poder de decisão sobre o que produzir individualmente dentro do Assentamento (3.1.1), uma vez que 86,67\% dos homens e 86,67\% das mulheres exercem essa autonomia. Outra questão que também se destaca está relacionada à decisão de comprar insumos quando precisa (3.1.6), já que ambos os sexos (100\%) se sentem livres para fazê-lo. Entretanto, a autonomia representada nestas questões se contrapõe à heteronomia verificada nas questões relacionadas às questões 3.1.9 e 3.1.10, as quais dizem respeito ao usufruto de bens e projetos comunitários. Em ambas as questões, 26,67\% dos entrevistados sinalizam que se sentem aparentemente excluídos dos benefícios da produção coletiva.

Com base nestes resultados, e em alguns trechos das entrevistas, abaixo apresentados, é possível verificar a clara diferenciação entre os objetivos das produções individual e coletiva. Enquanto a primeira está relacionada à composição da renda pessoal e familiar, necessária ao provento das necessidades da família e à busca por uma melhor qualidade de vida, a segunda tem uma função mais social, mais formativa, voltada à manutenção da cultura do associativismo que deu origem ao Assentamento, como podemos perceber mais adiante:

[...] porque é um momento ali da comunidade estar próxima né, e isso já é dos tempos antigos, essa coletividade. Então o movimento busca também ter essa interação da coletividade, mostrar porque, até mesmo os antepassados nossos né, faziam os mutirões, então o bom seria que a comunidade trabalhasse toda unida, até porque, em relação à produção, seria muito maior né, então é esse resgate também que o movimento busca fazer (ARECA, excerto extraído do Grupo Focal no 01, realizado em maio de 2016, p. 6).

[...] Uma prova viva nós convive aqui, por nós ter todas essas obras que nós temos aqui, é através do coletivo, porque se nós não tivesse esse coletivo, essa união de buscar, de enfrentar, fazer ali um mutirão, uma tarefa, com certeza não conseguiria toda essa estrutura que hoje nós temos; é devidamente esse esforço desse coletivo [...] se cada um conscientizar, a força que tem o coletivo, com certeza a gente se avançava muito mais (ARICURI, excerto extraído do Grupo Focal $\mathrm{n}^{\mathrm{o}}$ 01, realizado em maio de 2016, p. 6).

Como se vê, há uma grande defesa a favor dos processos coletivos de produção, destacando sua importância para a comunidade, e lhe atribuindo a maioria dos indicadores de desenvolvimento, hoje percebidos. Para Castoriadis (1991), a autonomia só pode conceber-se plenamente como empreitada coletiva. O autor, assim como Freire (2007), acredita que é um estado de consciência e liberdade que deve ser vivenciada a favor da coletividade. 
Altemar Felberg - Autonomia e Desenvolvimento Comunitário NO/DO Campo: Contradições e Consensos no Assentamento Luís Inácio Lula da Silva, do Movimento sem Terra - MST - em Santa Cruz Cabrália - Bahia/Brasil

Gráfico 07 - Dimensão social da autonomia para as mulheres - qualificação de mão-de-obra

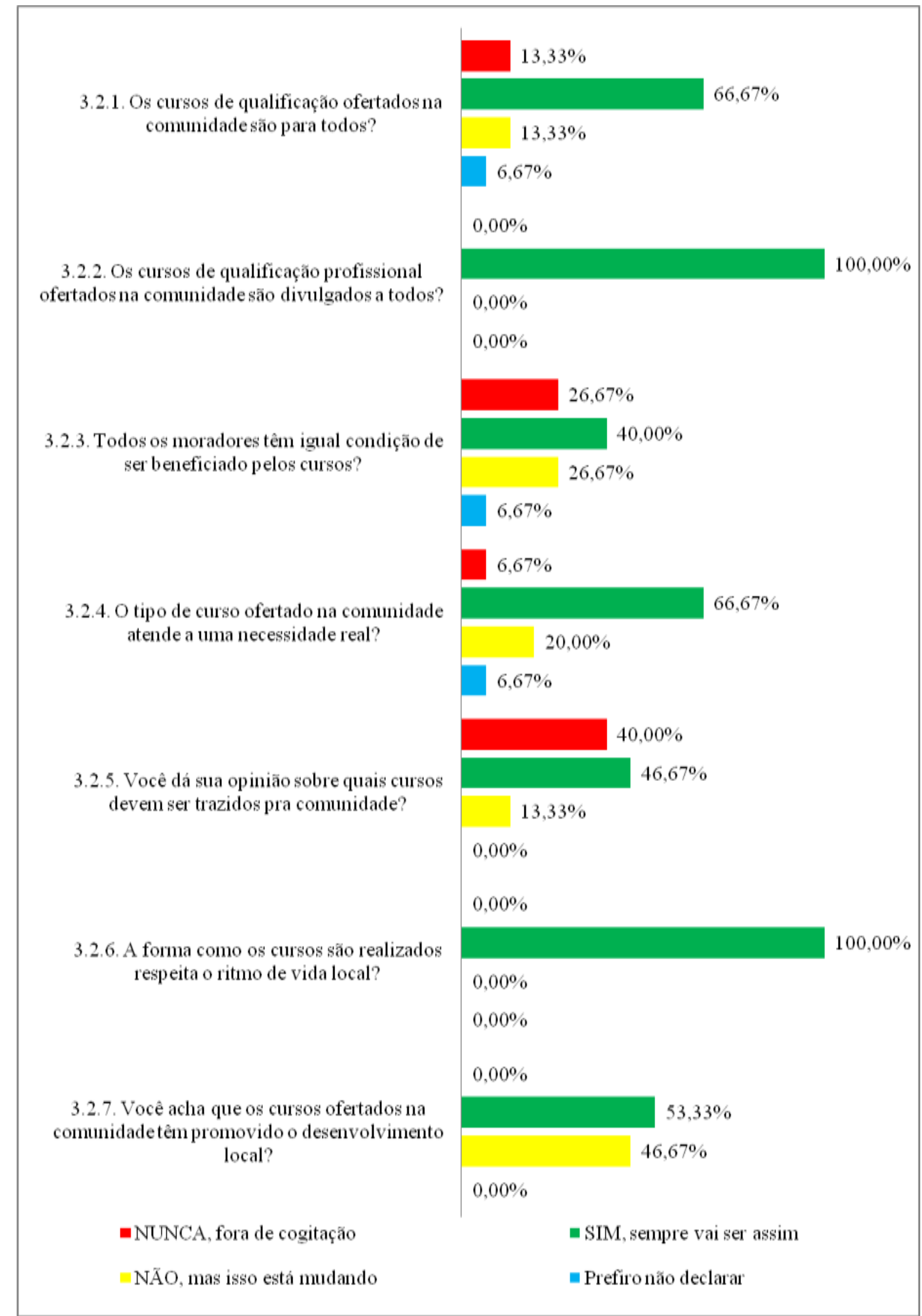


Altemar Felberg - Autonomia e Desenvolvimento Comunitário NO/DO Campo: Contradições e Consensos no Assentamento Luís Inácio Lula da Silva, do Movimento sem Terra - MST - em Santa Cruz Cabrália - Bahia/Brasil

Gráfico 08 - Dimensão social da autonomia para os homens - qualificação de mão-de-obra

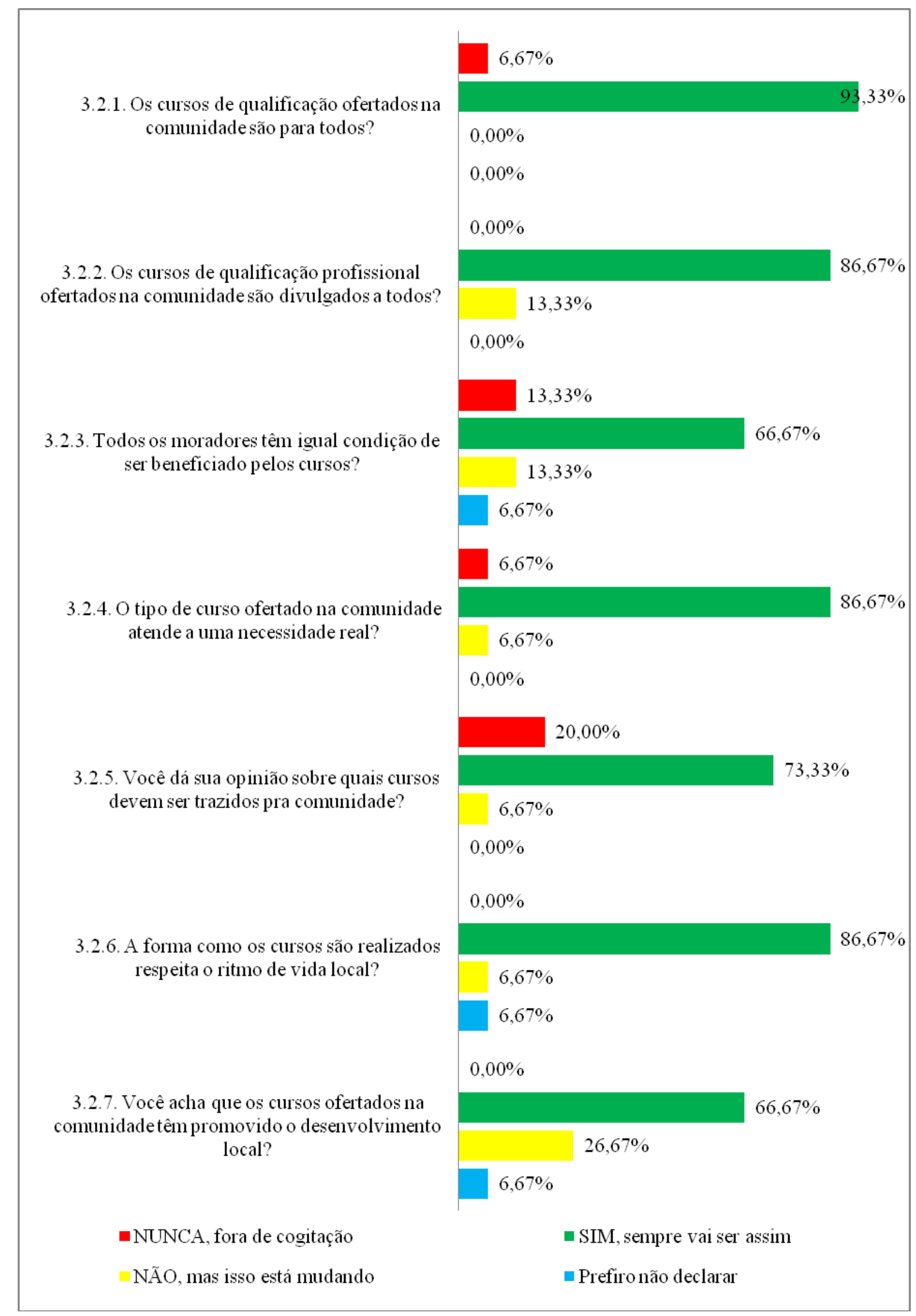


Altemar Felberg - Autonomia e Desenvolvimento Comunitário NO/DO Campo: Contradições e Consensos no Assentamento Luís Inácio Lula da Silva, do Movimento sem Terra - MST - em Santa Cruz Cabrália - Bahia/Brasil

No primeiro gráfico, que traz a qualificação de mão de obra na perspectiva das mulheres, 33,33\% sinalizam haver processos excludentes no acesso aos cursos ofertados (3.2.1), ainda que haja consenso de que existe ampla divulgação dos mesmos (3.2.2). Apenas 40\% afirmam ter igual condição de participação (3.2.3), talvez por não atenderem aos critérios de exigibilidade - o que é apenas uma hipótese. Também 40\% dos sujeitos dizem não opinar na escolha dos cursos, o que demonstra baixa participação no processo - dados que refletem, evidentemente, na opinião de que os cursos têm pouca participação $(53,33 \%)$ nos indicadores de desenvolvimento local (3.2.7).

Já no segundo gráfico, que traz a qualificação da mão de obra na perspectiva dos homens, $93,33 \%$ acreditam que os cursos são pra todos (3.2.1), enquanto $66,67 \%$ creem que todos têm igual condição de participação (3.2.3), e 73,33\% dão sua opinião na escolha dos cursos (3.2.5). No que se refere à contribuição desses cursos para o desenvolvimento do Assentamento, 66,67\% acreditam que os mesmos têm contribuído para tal fim.

Analisados conjuntamente, 66,67\% dos entrevistados (homens e mulheres) já foram beneficiados, pelo menos uma vez, com cursos de inclusão socioprodutiva realizados dentro do próprio Assentamento, por iniciativa de empresas do Sistema S (95\%), com destaque para o curso de piscicultura $(14,29 \%)$.

Paralelamente aos cursos ofertados gratuitamente no Assentamento, há também uma busca por qualificação particular fora da comunidade, conforme depoimento abaixo:

[...] eu, por exemplo, faço faculdade de enfermagem particular. Então, hoje eu tenho essa oportunidade de fazer isso, coisa que eu não tive antes, né, que hoje com 52 anos é que eu to fazendo isso, que eu estou tendo essa oportunidade, que o movimento, além de nos dar essa visão, né, de que a gente consegue as coisas, não se desanimar né... Tem também os estudos pelo movimento, e a gente não fica parado, cada dia que passa a gente quer saber mais, porque só o conhecimento liberta, né? Então a gente vai em busca desse conhecimento. Se a gente não consegue fazer por uma outra via, a gente vai pelo particular, porque hoje a gente conquistou isso, né? Então a gente vive hoje em uma área de zona rural, uma área de reforma agrária, onde a gente tem a possibilidade de garantir os nossos estudos (ARECA, excerto extraído do Grupo Focal no 01, realizado em maio de 2016, p. 6-7).

Interessante o crédito atribuído ao MST, mesmo na realização de cursos privados, o que demonstra que as conquistas individuais são resultado da trajetória de participação social no movimento. Para Sen (2008, p. 33), "ter mais liberdade melhora o potencial das pessoas para cuidar de si mesmas e para influenciar o mundo, questões centrais para o processo de desenvolvimento". 
Altemar Felberg - Autonomia e Desenvolvimento Comunitário NO/DO Campo: Contradições e Consensos no Assentamento Luís Inácio Lula da Silva, do Movimento sem Terra - MST - em Santa Cruz Cabrália - Bahia/Brasil

\section{Gráfico 09 - Dimensão social da autonomia para mulheres - participação social}

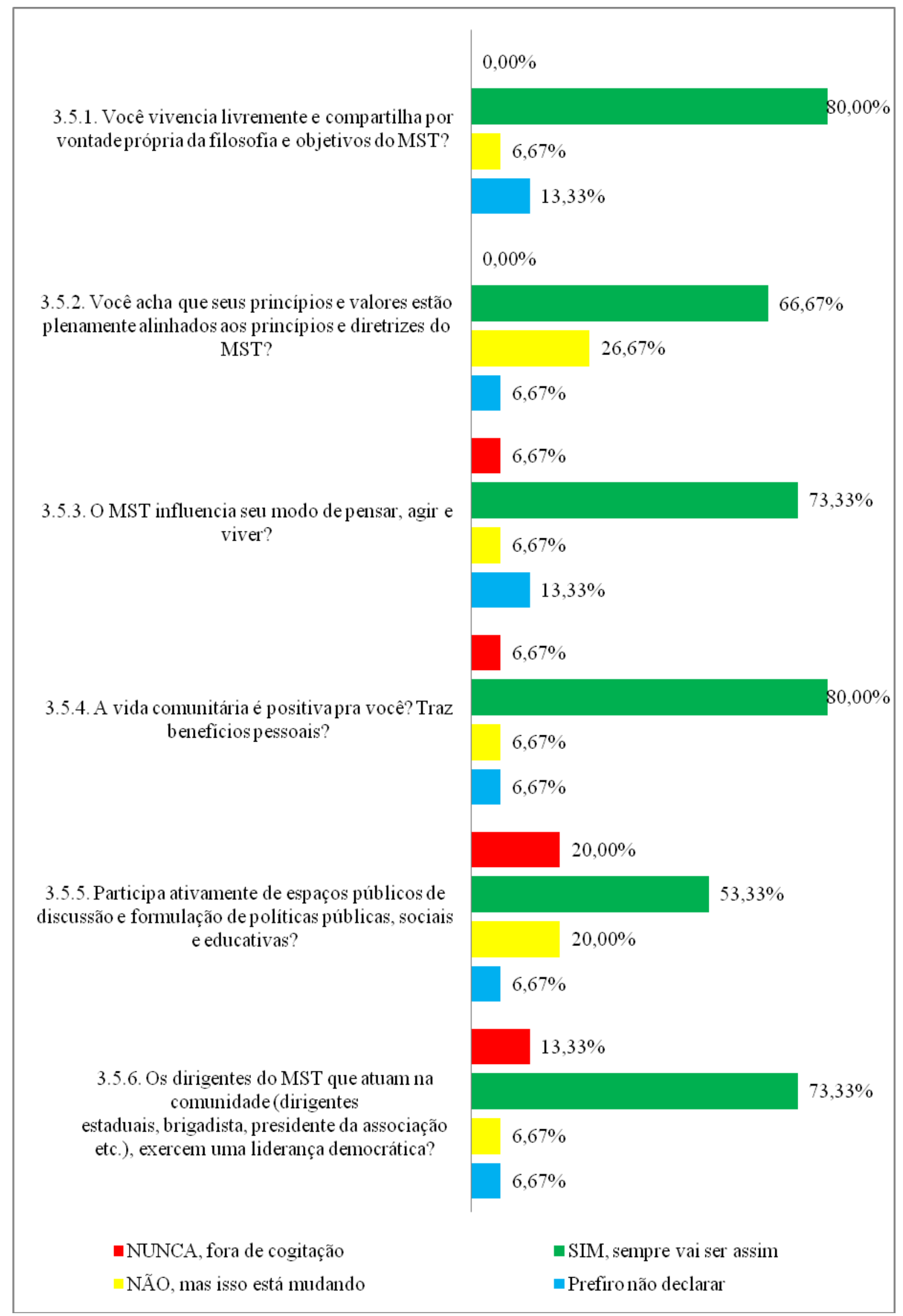

Universidade Lusófona de Humanidades e Tecnologias -FCSEA- Instituto de Educação 
Altemar Felberg - Autonomia e Desenvolvimento Comunitário NO/DO Campo: Contradições e Consensos no Assentamento Luís Inácio Lula da Silva, do Movimento sem Terra - MST - em Santa Cruz Cabrália - Bahia/Brasil

\section{Gráfico 10 - Dimensão social da autonomia para os homens - participação social}

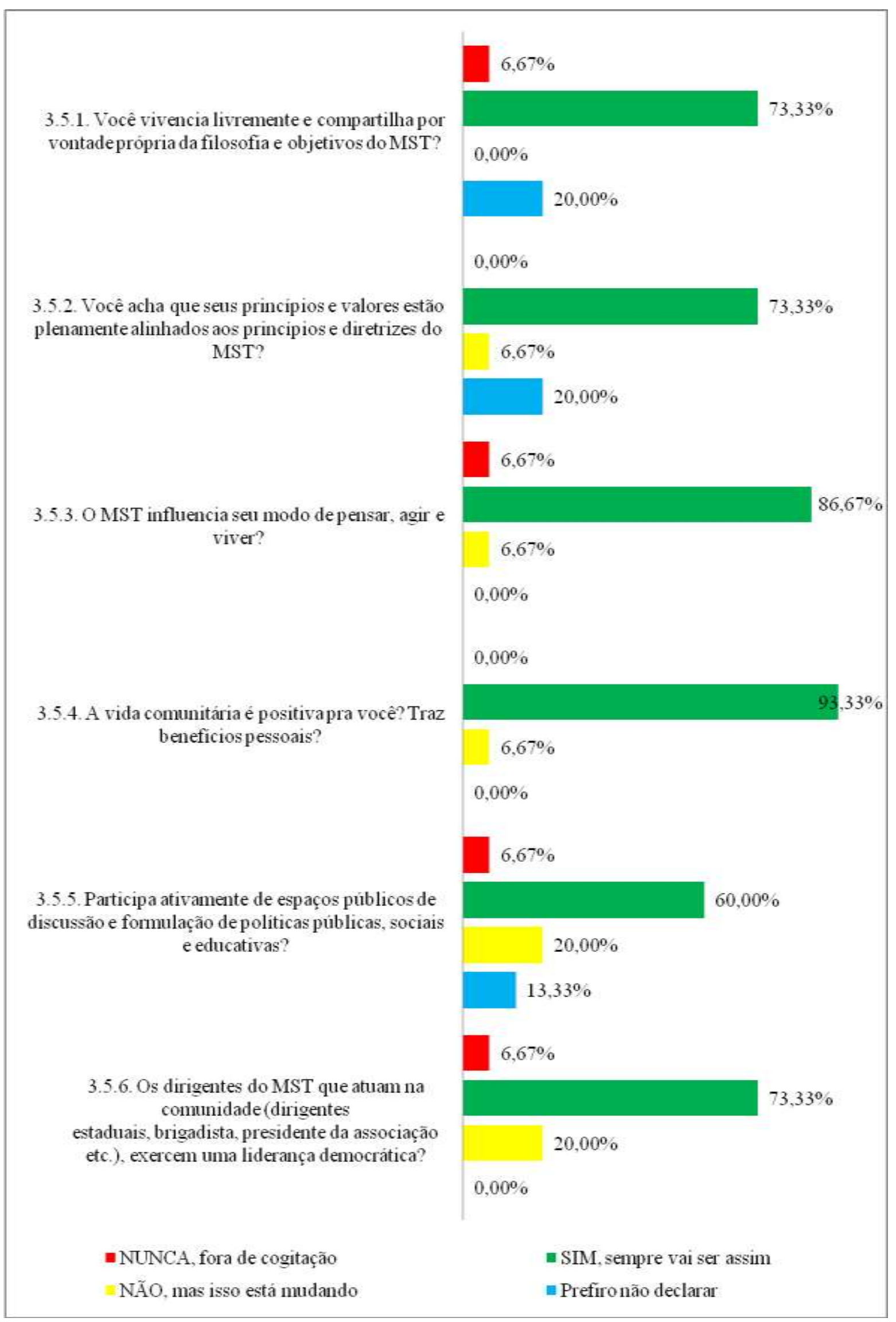

Universidade Lusófona de Humanidades e Tecnologias -FCSEA- Instituto de Educação 
O conceito de autonomia sempre se apresentou na literatura mundial vinculado à ideia de participação social e à ideia de ampliação da participação política, no que tange à descentralização do poder. Neste sentido, é que diversos autores enfatizam que "através de uma participação decisória e integrada de amplos contingentes da população local é possível aproveitar o saber-fazer, o conhecimento detalhado da realidade e a vontade de agir dos atores sociais locais" (ROVER; HENRIQUES, 2005, p. 12).

Essa participação mais qualificada dentro dos Assentamentos do MST se dá principalmente nas reuniões da assembleia geral, ocasião em que todos os assuntos de interesse coletivo são amplamente discutidos, com grande participação e envolvimento de toda a comunidade - homens, mulheres, jovens, idosos, crianças, adolescentes e terceiros convidados pelas lideranças, quando necessário.

Ela é importante pela tomada de decisão, então é em uma assembleia que você decide, que você define o rumo do assentamento né? Então é com a comunidade, é ela quem vai dizer ou sim ou não, então a assembleia é muito importante, porque é a unificação da comunidade (ARECA, excerto extraído do Grupo Focal no 01, realizado em maio de 2016, p. 5).

[...] a assembleia é justamente, né, pra isso, pra fazer com que cada um possa dar a sua opinião, cada um colocar o que pensa (+) quando vêm os projetos pra cá, vai aceitar? Não... Então cada um dá sua opinião, se quer aquele projeto, se aquele projeto serve, se não serve pra esse momento, né [...] Muitos, às vezes, vai lá e fala: "ah, eu quero" [...] aí faz aquela votação e é bom também pra informar algumas coisas que algumas pessoas não sabem ao certo o que significa, ou porque isto está acontecendo no movimento (+) as assembleias servem justamente pra esclarecer isso (BACURI, excerto extraído do Grupo Focal no 02, realizado em maio de 2016, p. 4).

Segundo dados do perfil socioeconômico e cultural dos Assentados do Lulão, quase que a totalidade dos moradores $(93,33 \%)$ é integrada à Associação dos Pequenos Produtores Rurais do Assentamento Luís Inácio Lula da Silva, participando ativamente dos eventos/ações promovidos pelo MST (assembleias, marchas, encontros etc.).

Sobre esta questão, Sen (2000) destaca que vivemos num mundo de instituições, e que nossas oportunidades e perspectivas de desenvolvimento dependem, essencialmente, do quanto estas contribuem ou não para o processo de expansão de nossas capacidades e liberdades individuais. Nesta perspectiva da avaliação do desenvolvimento, Carla Lyra (2005) defende que a atribuição de valor e importância à participação e autonomia dos indivíduos, oportunizando-os a protagonizarem socialmente, é uma das mais importantes estratégias para se alcançar o desenvolvimento sustentável. 
Altemar Felberg - Autonomia e Desenvolvimento Comunitário NO/DO Campo: Contradições e Consensos no Assentamento Luís Inácio Lula da Silva, do Movimento sem Terra - MST - em Santa Cruz Cabrália - Bahia/Brasil

Do total de mulheres entrevistadas, 66,66\% disseram ter participação frequente em todas as atividades promovidas pelo Movimento, enquanto que 33,33\% disseram participar esporadicamente. Seja nos indicadores quantitativos, seja nos relatos das assentadas entrevistadas, é notório o alto nível de participação social das mulheres na atual estrutura de organização social e política dos Assentamentos do MST.

\begin{abstract}
Ah, as mulheres ((risos)). Eu acho que as mulheres são bem mais participativas do que os homens viu, bem mais [...] a mulher, ela passa a reconhecer o seu papel, né, diante da sociedade, então essa questão família, a mulher ela passa mais a ver a questão do filho na escola, a água, e ela vai pra luta mesmo, então a mulher é participativa em tudo aqui dentro da área do Assentamento (ARECA, excerto extraído do Grupo Focal $n^{\circ}$ 01, realizado em maio de 2016, p. 4)
\end{abstract}

Quanto à participação social dos idosos da amostra pesquisada (13,33\% deles na faixa etária entre os 58 e 62 anos, e 10\% na faixa etária com mais de 62 anos), um fato interessante é que a eles é atribuída a responsabilidade por garantir as áreas de assentamento, no que diz respeito aos processos de ocupação de terras pelo MST, como bem destacado na fala a seguir:

É difícil, na questão do trabalhar, mas as áreas de assentamentos que a gente fala mais assim, quem garante as áreas dos assentamentos são os idosos. Hoje nós estamos envolvendo os jovens e aí nós estamos conseguindo, pela dificuldade muitas vezes que os jovens têm diante de recurso, né, pra sua subsistência. Geralmente ele vai embora, né, que estamos mudando essa realidade, estamos em busca de mudar essa realidade, que é o jovem sair do campo e ir pra cidade, trabalhar pra se sustentar, então o idoso, ele não, ele mantém ali o seu lote, trabalhando no dia a dia, mantendo a roça, então assim, os idosos tem uma importância muito grande para o movimento também, pelo fato dele garantir as áreas de assentamentos, é ele que tá ali, é ele que tem o sonho de voltar pra terra, que ele foi excluído por causa do êxodo rural. Então ele volta, mas aí, às vezes essa falta de sustentação dos jovens no campo, acaba os filhos deles voltando pra cidade, mas eles se mantêm ali, firmes, e a gente também busca esse envolvimento. Esse ano passado a gente fez, até, e a gente tá querendo fazer de novo, uma festa onde a gente comemora ali o idoso, justamente pelo fato dele garantir as áreas de assentamento, é ele que vai pra marcha, muitas vezes é ele que vai pras reuniões, né, porque o filho está na escola (ARECA, excerto extraído do Grupo Focal n ${ }^{\circ}$ 01, realizado em maio de 2016, p. 5).

No que diz respeito à participação dos jovens, como bem explicado no relato acima, há uma crescente estratégia do MST, no sentido de oportunizar e garantir a permanência do jovem no campo. Uma das estratégias utilizadas é criar grupos de trabalho internos, voltados para a juventude, dentro da estrutura organizacional da Associação, além de incentivar cada vez mais a busca pela formação e qualificação. 
Eu participo da juventude, eu e ele né ((apontou para outro sujeito))... Temos um grupo da associação que tem o presidente, o tesoureiro, a secretária, né, a vice, então tem outras partes que a gente participa (+) de viagens... E no caso, assim, eles sempre estão participando com a gente, na escola também eles sempre vêm aqui na escola, a gente também já trabalha dentro do assentamento, junto com a escola, ajudando, participando. Se precisasse mesmo antes da gente trabalhar aqui, a gente vinha e ajudava... (BABAÇU, excerto extraído do Grupo Focal no 02, realizado em maio de 2016, p. 3).

[...] mas assim, a maioria deles ajuda bastante, contribuem... pelo menos na nossa comunidade eles são bem participativos, eles têm roça coletiva que eles fazem, e gostam muito de participar dos seminários que têm às vezes, envolvendo a juventude, e esses encontros que a gente está sempre promovendo, eles são bem participativos, os jovens (BACURI, excerto extraído do Grupo Focal no 02, realizado em maio de 2016, p. 3).

Com base nos relatos acima, ficam perceptíveis distintos tipos de envolvimento e participação dos jovens no Assentamento Lulão: primeiro, o engajamento voluntário com os assuntos de interesse da comunidade, resultado de sua condição de agente; segundo, o envolvimento desses jovens pelas lideranças, no sentido de valorizá-los e apoiá-los na busca de alternativas que sustentem sua permanência no campo.

Evidencia-se, ainda, o quão os discursos da juventude estão alinhados à filosofia do MST e ao modelo de comunidade desejada pelo grupo. 


\section{CAPÍTULO III}

\section{EDUCAÇÃO DO CAMPO E A FORMAÇÃO DE SUJEITOS AUTÔNOMOS}


É inegável que o investimento no atendimento às necessidades humanas básicas melhora a produtividade e o crescimento econômico rumo à instauração de um modelo de desenvolvimento ético, que implica a garantia de direitos constitutivos da cidadania, capazes de promover maiores e melhores condições de reflexão e ação. Assim, nesse contexto da necessidade e do direito de se incluir socialmente e ter acesso aos bens e serviços públicos inerentes a todo cidadão, como preconiza os princípios fundamentais dos direitos humanos, fica evidente que a educação, em todas as suas dimensões, tem papel crucial nesse processo de libertação e empoderamento da sociedade.

Enfatizamos que não se acredita em desenvolvimento sem autonomia, e nem ambos sem a conquista do poder; do conhecimento que possibilita a percepção crítica da realidade e a reação frente às injustiças sociais. E é nesse movimento de ruptura, de ação, que a educação mostrou-se, ao longo da história, ser uma importante frente de luta, como já dizia Freire (1986). Desse modo, a educação, seja ela formal ou não, de fato tem contribuído para que as pessoas, especialmente os homens e as mulheres do campo, se sintam mais capazes de definir e controlar suas próprias prioridades para a mudança, rumo a esse novo modelo de desenvolvimento.

Historicamente, com base na trajetória histórica contada por Cury (2002), onde o mesmo aborda o direito à educação como um direito à igualdade e também como um direito à diferença, mais do que como uma exigência do mundo contemporâneo, ligada aos processos de produção de bens de consumo e de inserção qualificada no mundo do trabalho, a importância do direito à educação responde a valores da cidadania social e política. Segundo o autor, "buscam-se no processo histórico da modernidade, no acervo doutrinário e no conjunto normativo, inclusive internacional, as bases desses valores” (CURY, 2002, p. 245).

$\mathrm{O}$ direito à educação, como um direito humano reconhecido e declarado, é relativamente recente, e remonta ao final do século XIX e início do século XX. Dentre os principais documentos internacionais que abordam a questão, ainda segundo Cury (2002), destacam-se o art. XXVI da Declaração Universal dos Direitos do Homem, de 1948, a Convenção Relativa à Luta contra a Discriminação no Campo do Ensino, de 1960, e o art. 13 do Pacto Internacional dos Direitos Econômicos, Sociais e Culturais, de 1966.

No Brasil, especificadamente, o ensino fundamental como um direito é reconhecido desde 1934. A Constituição daquele ano disciplinou o direito à educação no artigo $5^{\circ}$, inciso XVI, e artigos 148 a 158. O artigo 149 o caracterizou como direito subjetivo público: 
[...] direito de todos e deve ser ministrada pela família e os poderes públicos, cumprindo a estes proporcionar o acesso a brasileiros e estrangeiros domiciliados no país, de modo que possibilite o desenvolvimento eficiente de valores da vida moral e econômica da Nação, e desenvolva num espírito brasileiro a consciência da solidariedade humana.

Ainda que considerada a matéria nas Constituições subsequentes, a de 1937 (Constituição do Estado Novo), a de 1946 (Constituinte Pós II Guerra Mundial) e a de 1967 (que acrescentou à primeira, a unidade nacional e a solidariedade humana), a Carta Magna de 1988 é, dentre as nossas Constituições, a que melhor discorreu e contemplou o reconhecimento de direitos e liberdades fundamentais, bem como a garantia para o seu acesso e exercício. Em 1988, a educação foi (e até hoje está) relacionada aos direitos sociais. Sua disciplina específica encontra-se no título relativo à Ordem Social, nos artigos 205 a 214.

Todavia, ainda que com grandes conquistas e avanços, especialmente no campo da garantia dos direitos sociais básicos, a Constituinte de 1988 não foi capaz de traduzir as necessidades e especificidades da educação dos sujeitos do campo, de forma plena. A reivindicação não era estritamente por direitos, mas também pela consolidação de um novo paradigma de sociedade, onde as bases da educação fossem pautadas no reconhecimento da existência de sujeitos sociais de direitos e de seres políticos, com histórias de vida, culturas e identidades singulares, a exemplo do homem e mulher que vive no/do campo, os quais reivindicam uma educação específica e diferenciada. A educação do campo é resultado da luta campesina pelo direito a terra, ao trabalho e a uma educação pensada e voltada especificadamente aos cidadãos do campo; uma árdua e recente luta pelo direito do povo brasileiro que vive e trabalha no campo, a uma educação de qualidade e diferenciada, que considere a história, valores, cultura e identidade do homem e mulher do campo.

Entretanto, apesar dos avanços na conquista de direitos, o quadro de exclusão com a consequente marginalização de indivíduos ainda é uma dura realidade brasileira, que precisa ser fortemente combatida. E nesse confronto é que precisa ser intensificada, pelas políticas públicas, sociais e educativas, provocadas pela Academia e pelos movimentos sociais organizados, a prática sociocultural de disseminação dos direitos e das iniciativas de promoção da autonomia - um grito a favor da oportunização de sujeitos com melhores condições de participar, igualitariamente, dos processos de desenvolvimento do nosso país.

A disseminação e a universalização da educação escolar de qualidade como um direito da cidadania são o pressuposto civil de uma cidadania universal e parte daquilo que um dia Kant considerou como uma das condições "da paz perpétua": caráter verdadeiramente republicano dos Estados que garantem 
este direito de liberdade e de igualdade para todos, entre outros. (CURY, 2002, p. 261-262).

Como já dissemos, não é preciso estar no dia a dia dessas populações (acampados, assentados, indígenas, quilombolas etc.) para notar o quadro de marginalidade e exclusão em que se encontram, delineado, principalmente, dentre outros fatores, pela ineficácia das políticas públicas, principalmente no que tange ao oferecimento de uma educação de qualidade e libertária da dependência e alienação - base primordial para a conquista do poder, em suas várias dimensões, capaz de promover e transformar a sociedade.

Para se ter uma ideia desse quadro de restrição do acesso ao direito à educação, a educação primária no Brasil, por exemplo, durante mais de meio século após sua independência, em 1822, era proibida aos negros escravizados, aos índios e às mulheres. Numa história mais recente, menos de $1 \%$ das pesquisas desenvolvidas no país tinham como tema a educação escolar no meio rural, segundo dados de Arroyo et. al. (2004). Se formos comparar mais profundamente, dados da educação no campo com a educação das cidades, veremos o quão grande é o abismo que as separam, refletindo a desigualdade no nosso país.

O enfrentamento a esse silenciamento e esquecimento à questão da educação do campo é justamente a bandeira de luta dos militantes do movimento Por uma Educação do Campo, apresentados pelos estudiosos: Miguel Arroyo, Roseli Caldart e Mônica Molina (2004).

Neste sentido, no que se refere à privação da educação com um direito inviolável de todo cidadão, sem qualquer distinção, acredita-se que a situação em que vive a maioria dos indivíduos do meio rural, homens e mulheres, é resultado, primeiro, da negligência do poder público, responsável, como comprovam os dados estatísticos, pela triste realidade social apresentada no país. Um poder que não dá espaço ou oferece alternativas para o crescimento das classes menos favorecidas, ou até as impede de conquistá-lo, incorrendo na incapacidade destas, de buscarem e conquistarem a sua autonomia e, consequentemente, o desenvolvimento por meio da educação.

Os autores citados acima corroboram este entendimento, quando destacam que o direito à educação vem sendo historicamente negado à população brasileira do campo, desde sempre. Enfatizam que, apesar dos movimentos docente e pedagógico progressistas do Brasil protagonizarem a história de luta pelo reconhecimento da educação como um direito humano, desde a década de 80, os avanços conquistados até então não repercutiram no campo. Afirmam que "os homens e as mulheres, as crianças, os adolescentes ou jovens do campo não 
estavam excluídos desse grito, porém não foram incluídos nele com sua especificidade. Consequentemente, ficaram à margem" (ARROYO et. al., 2004, p. 10).

No que tange às organizações da sociedade civil, reivindicadoras da garantia dos direitos constitucionais e cobradora do Estado no cumprimento de seu papel de provedor das necessidades coletivas, ora auxiliando como partícipe na implementação de políticas públicas, estas, na prática, não chegarão a produzir os resultados esperados, sem a especial atenção a uma questão maior - a promoção da educação libertária. Para tanto, em seus projetos de qualificação, precisam compreender que necessitam ultrapassar a si mesmas e a lutarem, de maneira organizada e verdadeiramente ética, pela promoção da autonomia dos indivíduos, não nutrindo inconsequentemente o individualismo, como nossa sociedade neoliberal requer, mas fomentando a autonomia como um processo de ação coletiva, em busca de soluções para a melhoria da qualidade de vida de todos.

Nessa perspectiva, Freire (1996) reforça que de nada adianta conquistar a autonomia, se esta não for utilizada para o bem comum, a favor da coletividade. Isto significa que o processo de expansão das liberdades e capacidades individuais só faz sentido se este vier carregado de um caráter social, voltado à transformação positiva da sociedade. Esse poder tem relação direta com a capacidade que têm os sujeitos, de conceber e fazer suas próprias escolhas, de decidir autonomamente sobre os rumos da sua vida, de refletir criticamente sobre o mundo e se firmar nele como sujeitos históricos, transformadores. E a conquista desse poder passa indiscutivelmente pela Educação.

Pensando o empoderamento como um compromisso de todos, como um processo de construção coletiva, que indubitavelmente passa pela autonomia individual, é que firmamos este trabalho, sob a ótica da conquista da autonomia nos âmbitos social, cultural, político e econômico, rumo ao desenvolvimento sustentável, num constante diálogo entre as temáticas, mediado pela educação e seu papel transformador.

Por fim, é preciso alertar que há um grande abismo entre o pensar certo e o agir certo, mas que precisa ser ultrapassado, se realmente desejarmos uma sociedade onde todos, sem levar em conta a condição do indivíduo, estejam realmente incluídos no processo de construção e usufruto do desenvolvimento. Nessa perspectiva, mesmo quando individualmente nos sentimos mais livres, mais empoderados, se não formos capazes de usar nossa liberdade e acesso recente em prol de oportunizar a outros este mesmo direito, então só estaremos exercitando uma atitude individualista, cada vez mais excludente. 


\subsection{Educação do Campo: contexto histórico, práticas e sujeitos}

Reconhecidamente, a Educação do Campo surgiu e se desenvolveu como crítica ao sistema e como resultado da luta de classes, protagonizado pelos atores sociais que reivindicavam a educação como um direito.

Preliminarmente à apresentação desta frente de entendimento da Educação do Campo enquanto fenômeno não apenas educativo, mas social, cabe aqui destacar os eventos que referenciam estas discussões e dão corpo ao movimento Por uma Educação do Campo.

Durante a I Conferência Nacional Por uma Educação Básica do Campo, realizada em Luziânia, Goiás, entre 27 a 31 de Julho de 1998, evento que, segundo seus participantes e idealizadores, é considerado o batismo coletivo de toda uma luta pelo direito à educação, em linhas gerais as discussões levaram a compreender melhor os seguintes aspectos: a) que tipo de educação estava sendo ofertada no campo, com a proposta de que esta educação deva ser mais ampla, voltada à formação humana do sujeito; b) o que se entende por educação básica e escolarização, resultando na formulação de uma proposta de escola do campo, que considere experiências exitosas e significativas de educação não formal e de caráter popular; c) a substituição do termo meio rural por campo, a fim de trazer ao termo a essência do conceito de camponês, que representa a diversidade de sujeitos que vivem do/no campo; d) a construção de pilares metodológicos para uma educação básica do campo, que representasse seu caráter diferenciado, assumindo a identidade do meio rural e voltado a um projeto nacional de desenvolvimento do campo brasileiro.

Um ano depois, em 1999, em uma palestra apresentada por Miguel Arroyo (2004), na I Conferência Nacional A Educação Básica e o Movimento Social do Campo, é refletida a dimensão educativa dos Movimentos Sociais, enraizando de vez a Educação do Campo na dinâmica das lutas sociais. Foi enfatizada a riqueza das experiências e aprendizagens adquiridas por Miguel Arroyo (2004), quando da sua participação no $1^{\circ}$ Encontro de Educadores dos Assentamentos de Belo Horizonte, em 1994, e na $1^{\text {a }}$ Conferência Nacional Por uma Educação Básica do Campo, em 1998, o que ele chama de 'pedagogia dos gestos, pedagogia do fazer', expressando as muitas formas de expressão e linguagens utilizadas pelos educadores e membros dos movimentos sociais do campo, que a todo o momento formam e educam para a cidadania, e argumentando sobre uma nova concepção de escola.

A grande reflexão e contribuição trazida pelo autor é a ideia do 'movimento social como princípio educativo' e como ferramenta de luta por direitos, uma vez que “o movimento 
social no campo representa uma nova consciência do direito a terra, ao trabalho, à justiça, à igualdade, ao conhecimento, à cultura, à saúde e à educação" (ARROYO et. al., 2004, p. 73).

Mais adiante, retratando a experiência particular das escolas do Movimento Sem Terra (MST) e sua proposta pedagógica de formação para a autonomia, a partir da dinâmica das lutas pela implementação de um projeto de desenvolvimento do campo, Roseli Salete Caldart publica o texto A Escola do Campo em Movimento, escrito em 2000.

O texto carrega em si três importantes argumentos e pontos de reflexão: o primeiro, que o campo no Brasil encontra-se em constante movimento e processo de mudança social; o segundo, que a Educação do Campo está sendo construída na dinâmica social desse processo desenvolvimentista, sendo retroalimentada a todo instante pelos atores sociais que dela participam; o terceiro, que é dinâmico o processo de humanização no campo, a partir da educação e da assunção de homens e de mulheres enquanto sujeitos sócio-histórico-culturais, agentes de transformação, protagonistas de suas próprias histórias de desenvolvimento, pessoal e social.

Em 2002, Bernardo Fernandes, em seu texto Diretrizes de uma Caminhada, faz menção a uma caminhada que se iniciou em 1997, quando da realização do Encontro Nacional de Educadores e Educadoras da Reforma Agrária (ENERA) - evento em que começavam a materializar as ideias progressistas que mais adiante resultaram na criação do Setor de Educação na estrutura organizacional do MST, que mesmo tendo todo o sistema educacional contra, alimentava o desiderato de uma 'nova escola'. A obra de Fernandes (2002) configura-se como uma grande conquista do Movimento Por uma Educação do Campo, iniciado em 1998, trazendo uma análise dos significados da aprovação, pelo Conselho Nacional de Educação, das Diretrizes Operacionais para a Educação Básica nas Escolas do Campo. Em síntese, a aprovação das referidas diretrizes representa a conquista da cidadania no meio rural, por meio da luta e a luta traduzida em lei, resgatando o campo como lugar de desenvolvimento humano, como "lugar de vida, onde as pessoas podem morar, trabalhar, estudar com dignidade de quem tem o seu lugar, a sua identidade cultural" (Ibid. p. 137).

E por último, finalizando a retrospectiva histórica do Movimento Por uma Educação do Campo, o texto Por Uma Educação do Campo: traços de uma identidade em construção, escrito por Roseli Caldart, a partir de sua exposição no Seminário Nacional Por uma Educação do Campo, realizado em Brasília, no período de 26 a 29/11 de 2002, que propõe reflexões sobre a identidade dos protagonistas do movimento e daqueles que pretendem 
Altemar Felberg - Autonomia e Desenvolvimento Comunitário NO/DO Campo: Contradições e Consensos no Assentamento Luís Inácio Lula da Silva, do Movimento sem Terra - MST - em Santa Cruz Cabrália - Bahia/Brasil

disseminar seu ideário. Nesse trabalho, a autora explica que o 'do’ da educação do campo faz referência à ideia de protagonismo do povo campesino, um 'do' que não é dado, mas conquistado com base em muita luta e sofrimento na busca por direitos e por inclusão. Assim, a educação do campo se moldou a partir da luta pela terra e por meio da mobilização das famílias sem-terra e dos educadores e educadoras do campo, que batalhavam pelo direito à escola, dentro dos espaços dos acampamentos e assentamentos do MST, tornando-se um princípio do próprio movimento.

Conforme retratado por Caldart (2000), foi justamente por melhores condições e qualidade de vida nos acampamentos e assentamentos do MST que a luta pelo direito à educação se juntou à luta pela terra, no começo sem muita relação. Todavia, desde o princípio da luta social, os trabalhadores e trabalhadoras do campo já carregavam em si a certeza de que uma transformação mais profunda se daria por meio da educação.

Uma educação que se alimente da UTOPIA... De nada adianta, para nossos objetivos maiores de transformação social, lutar por escolas e construir uma nova pedagogia, se isso não for inscrito num projeto de futuro e não ajudar a construir, nas novas gerações, a utopia e a convicção na possibilidade de mudanças. (CALDART, 1997, p.45)

Percebe-se, nesta afirmação de Caldart (1997), a necessidade de lutar pela instauração e consolidação de um modelo educativo dinâmico, que vise à formação para a autonomia, para a plenitude, para a formação de sujeitos qualificados à construção de novos paradigmas de Educação e Desenvolvimento, com mudanças educativas e sociais efetivas e duradouras, que inclua e considere o homem e a mulher do campo e suas utopias.

Essa pedagogia, que começou a se configurar no enfrentamento às dificuldades $\mathrm{e}$ desafios vivenciados pelas escolas dos assentamentos e acampamentos dirigidos pelo MST, construída e reconstruída pelos próprios sujeitos sem-terra, na dinâmica de como se dava e se dá suas vidas cotidianas, tem suas raízes nas pedagogias da autonomia e do oprimido, de Paulo Freire (1986), e nos estudos que abordam a relação do trabalho e educação, de Pistrak (2001) e Makarenko (1980;1991), defendido por muitos educadores do campo como um projeto libertador, revolucionário e coletivo, em constante atualização.

A pedagogia do MST é algo tão dinâmico e fluído, que extrapola a dimensão da escola, rompendo instituições e enquadramentos pedagógicos clássicos, comprometida com as classes historicamente subalternizadas e com a construção de um novo modelo de sociedade 
Altemar Felberg - Autonomia e Desenvolvimento Comunitário NO/DO Campo: Contradições e Consensos no Assentamento Luís Inácio Lula da Silva, do Movimento sem Terra - MST - em Santa Cruz Cabrália - Bahia/Brasil

que considere a formação humana, a formação política e ideológica e a formação econômica e histórica como elementos fundantes.

Neste sentido, Caldart (2001, p. 8), destaca que:

Enquanto sujeito pedagógico o MST não cria uma nova pedagogia, mas inventa um novo jeito de lidar com pedagogias já construídas na história da formação humana. Em outras palavras, a Pedagogia do Movimento em movimento a própria pedagogia, mobilizando e incorporando em sua dinâmica diversas e combinadas matrizes pedagógicas. Tal como na lavração que seus sujeitos fazem da terra, o MST ao fazer a formação humana revolve, mistura e transforma diferentes componentes educativos, produzindo uma síntese pedagógica que não é original, mas também não é igual a qualquer pedagogia já proposta, se tomada em si mesma, exatamente porque a sua referência de sentido está no Movimento.

Dessa forma, o MST não teve a pretensão de criar um novo modelo de educação para os sujeitos sem-terra, mas ao vivenciar diferentes situações cotidianas nas áreas de acampamento e assentamento - em que seus educadores tinham que combinar diferentes matrizes pedagógicas no processo de formação e conscientização de seus membros -, foi abrindo caminhos para novos entendimentos e interpretações sobre uma pedagogia de educação do campo diferenciada, voltada à formação para a autonomia, para a cidadania e para a humanidade. Sendo assim, na visão de Caldart (2001, p. 7),

Afirmar o movimento como princípio educativo da formação dos Sem Terra é considerar que seu processo educativo básico está no movimento mesmo, no transformar-se transformando a terra, as pessoas, a história, própria pedagogia, sendo esta a raiz e o formato fundamental da identidade pedagógica do próprio MST. Não por acaso que especialmente nos acampamentos seja comum a expressão ser do Movimento é estar em movimento.

Pensando sobre o prisma da necessidade de afirmação de uma nova pedagogia, podemos dizer que o MST possui, sim, uma pedagogia própria, ou melhor, uma práxis pedagógica de como se educar, formar e conscientizar seus integrantes. Podemos considerar que a pedagogia do MST é a forma como o movimento vem, ao longo dos tempos, formando o sujeito sem-terra, para que possa contribuir, com maior nível de consciência, com a consolidação do seu modelo de nação, de democracia, de desenvolvimento.

Neste processo de formação, a conquista e ocupação da terra, em especial, é um dos elementos-chave para o desenvolvimento de sua proposta social, pautada em formas próprias de organização e de utilização dos recursos existentes nas áreas de assentamento, como 
condição para sua reprodução cultural, social e econômica, utilizando conhecimentos, inovações e práticas geradas e transmitidas internamente pela própria vivência no movimento.

Na experiência pedagógica do MST, a luta social aparece como base da educação dos Sem Terra, exatamente porque aciona o movimento como princípio educativo, e se mistura com outros processos básicos ou potencialmente (con)formadores do ser humano: a relação com a terra, o trabalho, a construção de novas relações sociais de produção no campo, a vida cotidiana em uma coletividade, a cultura, a história, o estudo... luta mesma, afinal, transfigura-se ou desdobra-se em cada uma destas dimensões que se produziram como pedagogias ao longo da história da humanidade. Por isto afirmei que é o próprio movimento da luta o grande educador dos Sem Terra (CALDART, 2001, p. 8).

Trabalho e renda, qualificação de mão-de-obra, infraestrutura local, participação social e relação com o meio ambiente são, assim, elementos fundamentais para o desenvolvimento da humanidade, proposto pela pedagogia do MST.

No intuito de contribuir com a compreensão de qual é o papel da educação no processo de formação de sujeitos autônomos, um dos resultados desta pesquisa traz à reflexão questões como: garantia do direito à educação; processos de educação formal e não formal; o papel e influência do MST na formação dos sujeitos sem-terra; participação familiar e comunitária nos projetos desenvolvidos pela escola; qualidade do ensino e possibilidades de aprendizagem dentro e fora do Assentamento.

Os resultados que serão apresentados a seguir corroboram esse modelo educativo defendido por Caldart, que reconhece que a aprendizagem se dá na dinâmica da vida em sociedade, no exercício da cidadania e no movimento/vivência de luta. 
Altemar Felberg - Autonomia e Desenvolvimento Comunitário NO/DO Campo: Contradições e Consensos no Assentamento Luís Inácio Lula da Silva, do Movimento sem Terra - MST - em Santa Cruz Cabrália - Bahia/Brasil

\section{Gráfico 11 - Dimensão social da autonomia para as mulheres - educação}

3.4.1. Todos que desejam estudar dentro do Assentamento

(homens, mulheres, crianças, adolescentes e jovens) têm este direito garantido? Há escola pra todos?

3.4.2. Pra você, existe Educação sem Escola?

3.4.3. A luta pela terra, pelo trabalho e por condiçôes de uma vida digna no Assentamento, tem relação com a sua educação e a de seus filhos?

3.4.4. A missão do MST tem influênciapositiva no modo como você e seus filhos aprendem e vivem dentro e fora do Assentamento?

3.4.5. A Escola do Assentamento promove atividades pedagogicas que envolvem as familias e a comunidade?

3.4.6. Você participa das atividades que integram familia-comunidade-escola?

3.4.7. A Escola do Assentamento planeja suas atividades com a participação das familias e da comunidade?

3.4.8. Você participa das atividades de planejamento pedagógico da Escola?

3.4.9. Do seu ponto de vista, as escolas da cidade têm um ensino melhor do que da Escola do Assentamento?

3.4.10. Do seu ponto de vista, na cidade as possibilidades de aprendizagem são maiores?

3.4.11. Se seu filho(a) ganhasse uma bolsa para estudarnuma escola particular da cidade, você optariapor tirà-lo da Escola do Assentamento?

- NUNCA, fora de cogitação

NÃO, mas isso está mudando

\section{$0,00 \%$}

$0,00 \%$

$0,00 \%$

\begin{tabular}{|l|l|}
\hline & $33,33 \%$ \\
\hline $0,00 \%$ & $66,67 \%$ \\
$0,00 \%$ & \\
$0,00 \%$ & \\
\hline
\end{tabular}

$0,00 \%$

$0.00 \%$

$0,00 \%$

$0,00 \%$
$6,67 \%$
$0,00 \%$

$93,33 \%$

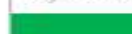

$80,00 \%$

$6,67 \%$

$13,33 \%$

$6,67 \%$

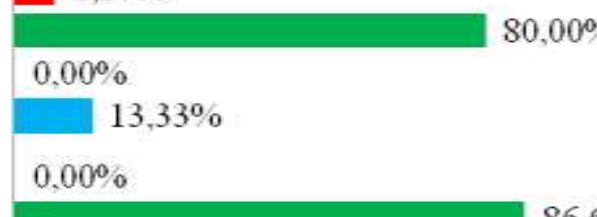

0,0

$0,00 \%$

$13,33 \%$
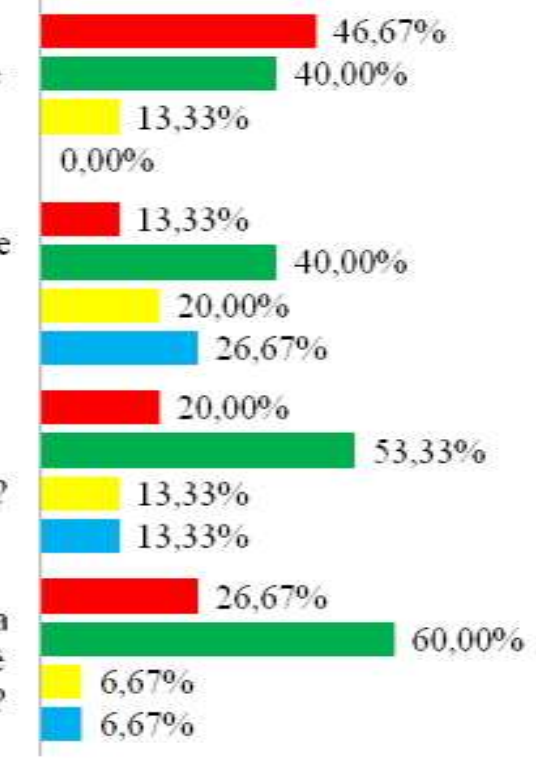

= SIM, sempre vai ser assim

E Prefironão declarar 
Altemar Felberg - Autonomia e Desenvolvimento Comunitário NO/DO Campo: Contradições e
Consensos no Assentamento Luís Inácio Lula da Silva, do Movimento sem Terra - MST - em Santa
Cruz Cabrália - Bahia/Brasil

Altemar Felberg - Autonomia e Desenvolvimento Comunitário NO/DO Campo: Contradições e
Consensos no Assentamento Luís Inácio Lula da Silva, do Movimento sem Terra - MST - em Santa
Cruz Cabrália - Bahia/Brasil

Altemar Felberg - Autonomia e Desenvolvimento Comunitário NO/DO Campo: Contradições e
Consensos no Assentamento Luís Inácio Lula da Silva, do Movimento sem Terra - MST - em Santa
Cruz Cabrália - Bahia/Brasil

\section{Gráfico 12 - Dimensão social da autonomia para os homens - educação}

3.4.1. Todos que desejam estudar dentro do Assentamento

(homens, mulheres, crianças, adolescentes e jovens) têm este direito garantido? Há escola pra todos?

3.4.2. Pra você, existe Educação sem Escola?

3.4.3. A luta pela terra, pelo trabalho e por condições de uma vida digna no Assentamento, tem relação com a sua educação e a de seus filhos?

3.4.4. A missão do MST tem influência positiva no modo como você e seus filhos aprendem e vivem dentro e fora do Assentamento?

3.4.5. A Escola do Assentamento promove atividades pedagógicas que envolvem as familias e a comunidade?

3.4.6. Você participa das atividades que integram familia-comunidade-escola?

3.4.7. A Escola do Assentamento planeja suas atividades com a participação das familias e da comunidade?

3.4.8. Você participa das atividades de planejamento pedagógico da Escola?

3.4.9. Do seu ponto de vista, as escolas da cidade têm um ensino melhor do que da Escola do Assentamento?

3.4.10. Do seu ponto de vista, na cidade as possibilidades de aprendizagem são maiores?

3.4.11. Se seu filho(a) ganhasse uma bolsa para estudar numa escola particular da cidade, você optaria por tirà-lo da Escola do Assentamento?

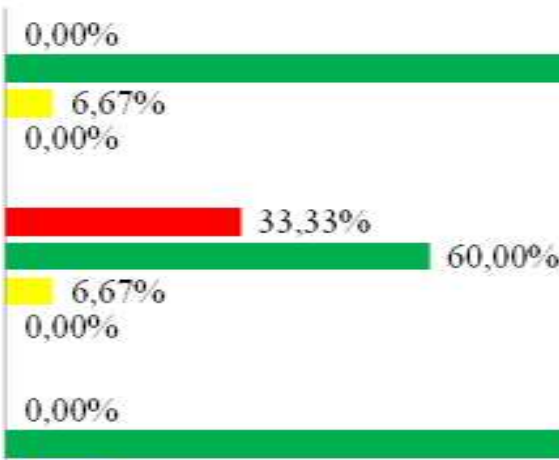

$80,00 \%$

\begin{tabular}{|c|}
\hline $13,33 \%$ \\
\hline $6,67 \%$ \\
\hline $0,00 \%$ \\
\hline $6,67 \%$ \\
\hline $13,33 \%$ \\
\hline $0,00 \%$ \\
\hline
\end{tabular}

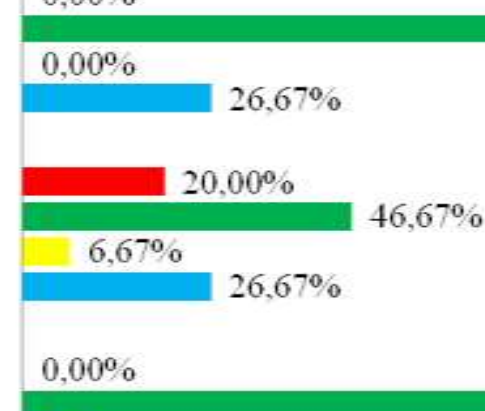

$73,33 \%$
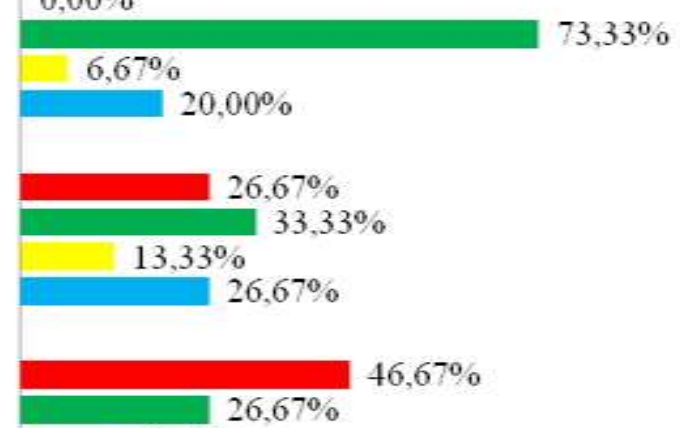

$13,33 \%$

$13,33 \%$

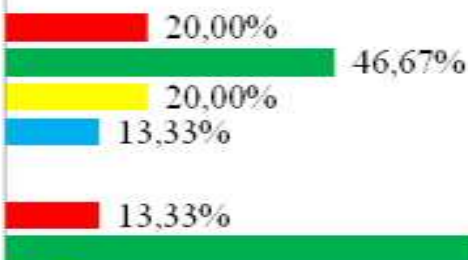

$66.67 \%$ 
A oferta de educação formal, dentro do assentamento, os processos de luta social como estratégias de formação do sujeito, o MST como princípio educativo, e a participação da família, escola e comunidade nos processos de ensino-aprendizagem são algumas das principais questões representadas neste gráfico, que tenta traduzir a percepção da comunidade acerca da educação vivenciada no Assentamento.

Antes de realizarmos uma análise mais global da questão, cabe-nos aqui fazer algumas considerações sobre alguns dados específicos trazidos nestes dois gráficos. Primeiro, na questão relacionada à oferta de educação formal, dentro do assentamento (3.4.1), 100\% das mulheres e 93,33\% dos homens afirmaram ter este direito garantido, com igualdade de oportunidade a todos que desejam estudar. Segundo, no que concerne aos processos de luta social como estratégias de formação do sujeito (3.4.3), 100\% das mulheres e $80 \%$ dos homens atestaram que a luta pela terra, pelo trabalho e por condições de uma vida digna tem relação com a sua educação e a de seus filhos. Terceiro, no que diz respeito ao MST, como princípio educativo (3.4.4), 93,33\% das mulheres e $80 \%$ dos homens reconheceram que a participação do movimento tem influência positiva no modo como eles e seus filhos aprendem e vivem dentro e fora do Assentamento.

Tanto nos dados quantitativos, trazidos nos gráficos, quanto nos qualitativos, representados nos relatos dos sujeitos, evidencia-se a importância atribuída à educação para o desenvolvimento sócio-econômico-cultural e ambiental do assentamento, dando grande destaque ao MST como promotor da expansão das liberdades e capacidades dos sujeitos, formando-os para o exercício da cidadania.

Fazendo uso das palavras de Cury (2002, p. 260),

O acesso à educação é também um meio de abertura que dá ao indivíduo uma chave de autoconstrução e de se reconhecer como capaz de opções. $\mathrm{O}$ direito à educação, nesta medida, é uma oportunidade de crescimento cidadão, um caminho de opções diferenciadas e uma chave de crescente estima de si.

Nesta percepção de formação para a autonomia, Caldart (2011, p. 5) defende que "os Sem Terra se educam, quer dizer, se humanizam e se formam como sujeitos sociais no próprio movimento da luta que diretamente desencadeiam".

A educação é a base de tudo, né, então, assim, se você não tem educação, só através da educação você consegue até mesmo lutar, né, porque se você não tiver educação, você não tem a capacidade de ir pra luta, né, então é o conhecimento, né, esse conhecimento vem através da educação [...] não ter 
dinheiro é uma coisa, agora você, enquanto pessoa, você tem os seus direitos, né, você tem o direito a estudar, é através do estudo que você vai ter uma vida mais digna, né, porque o conhecimento é algo que ninguém tira de você, não é? Então é isso que você leva pra sua vida, e o movimento sem terra esclarece muito bem nessa busca que ele faz, é dizer "ó, você tem direitos, né, você é dono do seu próprio destino, não é os outros que vai fazer o seu destino, e sim você mesmo" (ARECA, excerto extraído do Grupo Focal $\mathrm{n}^{\circ}$ 01, realizado em maio de 2016, p. 9).

Como destaca Freire (1983, p. 32), conquistar a própria autonomia implica em libertação das estruturas opressoras. "A libertação a que não chegarão pelo acaso, mas pela práxis de sua busca; pelo conhecimento e reconhecimento da necessidade de lutar por ela".

O movimento tem uma frase bem interessante pra gente, que nos chama atenção: "o assentamento é a nossa escola, e o MST é o nosso principal educador". Essa frase, ela acaba ajudando a todos nessa parte da educação, , em primeiro lugar, primeiramente em tudo, pra gente buscar tudo, a gente precisa ter a educação. Não é a educação que é em quatro paredes, que é uma escola ali que vai formar, e sim aquela educação que, ao buscar, ao agir, e aquela educação diferenciada que você precisa compreender que não é só em quatro paredes que você vai obter essa educação, é nessa conversa que a gente ta tendo aqui que a gente vai direcionar, que a gente vai buscar esse passo a passo, não precisa a gente tá nessa visão e só em quatro paredes, mas debaixo de um pé de árvore, em uma palestra que a gente tem ali... Na busca pela educação, o movimento, ele se preocupa muito, a primeira instância, quando ele se preocupa em montar num acampamento, o segundo objetivo dele é a escola, ali junto com a saúde, então nessa parte que ele busca, eles procura buscar cada dia mais cursos que às vezes a gente vai tá em uma reunião, em uma assembleia, por exemplo, ali nós achamos que só é uma discussão que tá no assentamento, muitos não consegue compreender que aquela assembleia tá sendo uma escola, porque aquela assembleia ali, ela tá direcionando, então isso que é interessante, que a cada dia me passa a cativar mais pelo movimento, porque você, sem perceber, acaba, a cada instante, aprendendo, como diz, somos eternos aprendiz né, a cada momento a gente tá ali buscando/.../ (ARICURI, excerto extraído do Grupo Focal no 01, realizado em maio de 2016, p. 8).

Nos relatos acima fica evidente o quão educativo é a vivência dos processos de luta pela terra e manutenção e desenvolvimento das áreas de assentamento. A escola se configura como mais uma ferramenta de formação para a autonomia dos sujeitos que ali vivem, dentre tantas outras que se desenvolvem na dinâmica da vida em comunidade. Não é por acaso que os educadores e educadoras do MST disseminam a célebre frase "o assentamento é a nossa escola e o MST é o nosso principal educador". Fazem isso por reconhecerem e valorizarem a própria vivência no MST como uma estratégia de educação transformadora. 
Evidencia-se, ainda, neste relato, a relevância da educação não formal dentro do MST, uma educação para além dos muros da escola, que se dá na práxis da vida cotidiana, no exercício da cidadania e na participação social. Uma educação que se oportuniza na luta por direitos, no enfrentamento às estruturas de poder e opressão, o que Kant (1996) bem defende, quando diz que a educação não deve ser puramente mecânica e nem se fundar no raciocínio puro, mas deve apoiar-se em princípios e guiar-se pela experiência.

Os resultados vão ao encontro de dados já publicados em pesquisa realizada em três assentamentos do MST, em Santa Catarina, por Vendramini (2000, p. 215-6), que teve como pergunta, "onde mais se aprende", e surpreende ao apontar que os espaços de aprendizagem mais significativos dentro do MST são: Movimento/vivência na luta - 38\%; Casa/família 24\%; Escola - 17\%; Igreja - 10\%; e Leituras/palestras -10\%.

Todavia, formar para a autonomia, tornar consciente e reflexivo este processo de aprendizagem que se dá na trajetória de luta, para Caldart (2011) é um dos grandes desafios pedagógicos do MST na atualidade, e uma das principais razões de se valorizar cada vez mais as estratégias e práticas pedagógicas próprias, desencadeadas no interior dos assentamentos e acampamentos do MST, como bem retratado no relato de Aricuri.

Somente nos assumindo como seres sócio-histórico-culturais, como recomenda Freire (2007), nos reconhecendo como sujeitos de ação e ressignificação na/da história, poderemos avançar nesta expansão de capacidades e liberdades, neste estado de consciência crítica e reflexão a que chamamos de autonomia. Sem isto, conforme Caldart (2011), os novos sujeitos sociais não conseguirão se tornar sujeitos políticos, capazes de fazer diferença no desenrolar da luta de classes e na reconstrução de um projeto revolucionário de nação.

Para a autora, não há como ser um sujeito político, sem antes se aprender a ser um sujeito social. E, por conseguinte, não há como saber ser um sujeito social, participativo, coletivo, sem compreender-se como partícipe e autor no processo histórico da luta e da formação humana. Assim, fica evidente que ética comunitária, solidariedade com os outros e com o coletivo, consciência sobre os direitos sociais, democracia de base e respeito às diferenças, assunção como sujeito sócio-histórico-cultural e compreensão de que a vida é um movimento, são algumas das dimensões deste processo pedagógico, "fruto da vivência no cotidiano dos assentamentos dos sem-terra" (CALDART, 2004, p. 178-186). 
Altemar Felberg - Autonomia e Desenvolvimento Comunitário NO/DO Campo: Contradições e Consensos no Assentamento Luís Inácio Lula da Silva, do Movimento sem Terra - MST - em Santa Cruz Cabrália - Bahia/Brasil

\section{CAPÍtulo IV}

\section{DESENVOLVIMENTO COMUNITÁRIO RURAL}


Em retrovisão histórica, podemos notar que o fenômeno da globalização é bastante recente, não ultrapassando cinco séculos de existência. Seu surgimento, segundo Braudel (1996), remonta à fase do mercantilismo europeu, com a expansão marítima no século XV, amadurecendo com o advento da revolução industrial e as políticas imperialistas e colonialistas do século XIX, e se consolidando em todo o mundo, com a globalização neoliberal do século XX. Para o autor, em cada etapa o fenômeno recebe características próprias do momento histórico em que se estabeleceu.

Ainda na visão do autor, antes do expansionismo mercantilista do século $\mathrm{XV}$, não existia praticamente relação alguma entre as economias mundiais, o que só foi oportunizado pela expansão marítima, uma vez que, anterior ao século XV, a economia mundial era restrita a cinco blocos totalmente autônomos e relativamente autossuficientes: Europa, na região de Flandres e a Liga de Hansas; China, com a Coréa, Indochina e Malásia; Índia; África; e as civilizações pré-colombianas.

Para melhor entendimento deste processo de universalização da economia global, podemos dividir a globalização em duas fases - uma marcada pelos interesses econômicos e outra pelo desejo de centralização política das monarquias absolutistas.

A primeira fase pode ser caracterizada sob o ponto de vista econômico, por amplos investimentos estatais e privados europeus, em busca de novas rotas marítimas em direção às novas economias: China, Índia, África e América. É notório que, nessas novas terras conquistadas, as atividades eram desenvolvidas de acordo com o potencial local encontrado e seu projeto de ocupação. Na América, ao Sul, a exemplo do Brasil, desenvolveram-se colônias de exploração baseadas na monocultura e no trabalho escravo indígena e africano, com grande impacto na vida dos povos originários (expropriação de suas terras, escravização e destruição de sua cultura) e incentivo ao tráfico de negros da África. Ao Norte, as colônias eram de povoamento, baseadas na propriedade de exploração familiar. Diferentes modelos de colonização explicam grande parte do abismo social hoje existente nas Américas.

Em sua segunda fase, a globalização pode ser caracterizada sob o ponto de vista político, na perspectiva de uma globalização do século $\mathrm{XV}$, que se fez sob a tutela das grandes monarquias absolutistas, que pelo desejo de maior supremacia e centralização política, se articulavam e mobilizavam recursos financeiros e militares com o único objetivo de alcançar outras terras, em busca da ampliação de seu poderio político e consolidação de seus impérios. Portugal, Espanha, Inglaterra, França e Holanda são os países que se destacaram nessa etapa da globalização. 
No campo político e social, mais adiante, no século XVIII, duas grandes revoluções dão importante marca à globalização - a Revolução Industrial Americana e a Revolução Francesa. Ambas contribuíram significativamente para uma mudança nas relações entre as diversas camadas da sociedade, principalmente dos países do Ocidente. Com a classe operária ganhando destaque, e a classe média se fortalecendo, é ameaçado o plano da classe rica e dominante, de acumular capital à custa da exploração da classe trabalhadora, acirrando ainda mais os conflitos sociais que se arrastam até os dias atuais, com grandes consequências socioeconômico-culturais.

O fenômeno da globalização foi construído sob a lógica imposta pelo capital dominante, que visava atender, única e exclusivamente, aos interesses dos estados absolutistas e/ou imperialistas, elidindo qualquer possibilidade de favorecer outros grupos. Na avaliação de Teodoro (2011), a globalização trouxe consequências não apenas à economia mundial, mas impactou diversos outros aspectos da vida social moderna, influenciando a maneira de viver das pessoas e intensificando os processos de exclusão. É justamente sobre a desigualdade resultante deste processo que Boaventura Sousa Santos (2002) faz sua interpretação:

Se para alguns ela continua a ser considerada como o grande triunfo da racionalidade, da inovação e da liberdade capaz de produzir progresso infinito e abundância ilimitada, para outros ela é anátema já que no seu bojo transporta a miséria, a marginalização e a exclusão da grande maioria da população mundial, enquanto a retórica do progresso e da abundância se torna em realidade apenas para um clube cada vez mais pequeno de privilegiados (SANTOS, 2002, p. 53).

Na visão do autor, fica evidente a exclusão de grande contingente populacional - as classes historicamente vulnerabilizadas e subalternizadas - neste processo de mundialização da economia que cuidou de satisfazer a necessidade cada vez mais crescente de consumo da população capitalista mundial, e é aí que se insere o desenvolvimento no campo, com o papel de suprir as novas demandas do mercado, especialmente por alimentos.

Conforme Navarro (2001), estes últimos 50 anos em que a noção de desenvolvimento encontrou destaque na singularidade histórica do país, o Estado, assim como os grupos sociais, mostraram intenso interesse em discutir o assunto, e principalmente seus benefícios, sendo cerne dos programas governamentais e pauta constante da agenda política nacional, determinando, de vez, as expectativas e o jogo das disputas sociais. 
Altemar Felberg - Autonomia e Desenvolvimento Comunitário NO/DO Campo: Contradições e Consensos no Assentamento Luís Inácio Lula da Silva, do Movimento sem Terra - MST - em Santa Cruz Cabrália - Bahia/Brasil

De acordo com o autor, a questão do desenvolvimento começou a ser debatida logo após a Segunda Guerra Mundial, em virtude da necessidade de reconstrução dos países, perdurando até o final dos anos 70.

Nesse longo período, instigado pela polarização da Guerra Fria e seus opostos modelos de sociedade e, particularmente, sob o impacto do notável crescimento econômico da época, que materializou um padrão civilizatório dominante, revolucionando o modo de vida e os comportamentos sociais, a possibilidade do desenvolvimento alimentou esperanças e estimulou iniciativas diversas em todas as sociedades. (NAVARRO, 2001, p. 83)

Ainda para Navarro (2001), naturalmente que no Brasil, sendo um país agrário, os desdobramentos do desenvolvimento recairiam, inevitavelmente, sobre as atividades de produção agrícola. Foi aí, então, que a questão do desenvolvimento rural começou a ser discutido nas academias, sendo o grande propulsor dos programas governamentais e o alvo dos interesses sociais.

Neste mesmo período, segundo o autor, dado aos investimentos e debates teóricos acerca do assunto, acumulado ao aperfeiçoamento dos sistemas de produção, a agricultura ganha status de mola propulsora do desenvolvimento em vários países, movimento que ficou conhecido como revolução verde $e^{22}$.

Com a disseminação de tal padrão na agricultura, desde então chamado de "moderno", o mundo rural (e as atividades agrícolas em particular) passou a subordinar-se, como mera peça dependente, a novos interesses, classes e formas de vida e de consumo, majoritariamente urbanas, que a expansão econômica do período ensejou, em graus variados nos diferentes países. Esse período que coincide com a impressionante expansão capitalista dos "anos dourados" (1950-1975), é assim um divisor de águas também para as atividades agrícolas, e o mundo rural, (re)nasceria fortemente transformado, tão logo os efeitos desta época de transformação tornaram-se completos. (NAVARRO, 2001, p. 84).

Especificadamente no caso do Brasil, foi a partir dos anos 1970, sob domínio do regime militar, que o país deu início a um plano desenvolvimentista em regiões mais pobres, a

\footnotetext{
${ }^{22}$ Apoiada em uma promessa de aumento da oferta de alimentos que proporcionaria a erradicação da fome, a Revolução Verde resultou em um novo modelo tecnológico de produção agrícola que implicou na criação e no desenvolvimento de novas atividades de produção de insumos (químicos, mecânicos e biológicos) ligados à agricultura. Esse modelo produtivo passou, no entanto, a apresentar limites de crescimento a partir da década de 1980, com a diminuição do ritmo de inovações, o aumento concomitante dos gastos em P\&D e a identificação dos impactos ambientais advindos do uso intensivo desses insumos, em especial dos agrotóxicos. Fonte: ALBERGONI, L.; PELAEZ, V (2007, p. 32).
} 
Altemar Felberg - Autonomia e Desenvolvimento Comunitário NO/DO Campo: Contradições e Consensos no Assentamento Luís Inácio Lula da Silva, do Movimento sem Terra - MST - em Santa Cruz Cabrália - Bahia/Brasil

exemplo do Nordeste, onde os índices de pobreza eram considerados extremos, conforme Navarro (2001). Para o autor, enquanto nas regiões mais abastadas o sentimento era de 'modernização agrícola', no nordeste do país o termo utilizado era de 'desenvolvimento rural', associado a um processo de aumento da renda familiar e consequente melhoria das condições de vida daquela população, através da agricultura.

Embora o desenvolvimento rural tenha sido fortemente intensificado entre as décadas de 1970 e 1980, em meados de 1980 já se começava a sentir as consequências do "estancamento da fase econômica expansionista do pós-guerra" (NAVARRO, 2001, p. 85). A partir dos anos 80, portanto, inspirado pelo modelo neoliberal, que enfraqueceu fortemente o papel do Estado na condução das políticas públicas, o governo retirou das pautas prioritárias da agenda governamental, as discussões acerca do desenvolvimento rural.

Ainda conforme o autor, o interesse pela temática do desenvolvimento rural ressurge a partir dos meados dos anos 1990, com a aparente impossibilidade de desenvolvimento ou pelo menos a dificuldade de sua materialização, que pairava sobre o país na época, diante da internacionalização da economia e sua consequente instabilidade gerada pela globalização. Com o seu advento, a temática do desenvolvimento rural retoma destaque nos debates sociais, agora com dimensões globais, principalmente numa época em que a questão ambiental é fortemente discutida, instigando, portanto, o desenvolvimento de novas técnicas de produção não agressivas ao meio ambiente, que sejam capazes, sobretudo, de satisfazer a necessidade cada vez mais crescente de consumo da população capitalista mundial.

No que se refere ao "mundo rural", a percepção da necessidade de uma nova abordagem para a questão do desenvolvimento ganhou fôlego especialmente através da proliferação de ideias e noções que foram importadas para o Brasil por pensadores e estudiosos. Como exemplo deste ideário intelectual que passou a afetar o que Habermas chamou de mundo da vida e a exercer uma influência crescente no debate sobre o desenvolvimento, basta citar a discussão em torno da sustentabilidade e da problemática ambiental, do enfoque local e territorial, das atividades rurais não agrícolas, das interrelações rural-urbano, entre outros (SCHNEIDER, 2004, p. 88).

Com base no que foi apresentado até aqui, vimos que várias estratégias adotadas pelos governos do país, como o modelo desenvolvimentista implantado a partir dos anos 50, tiveram como objetivo reverter a situação de disparidade social ocasionada pelos altos índices de concentração de renda. Verifica-se, no entanto, que após meio século da implantação do referido modelo de intervenção, os problemas relacionados à má distribuição de riquezas no Brasil, e suas consequências, imperam, principalmente na região Nordeste. Com a emergência 
Altemar Felberg - Autonomia e Desenvolvimento Comunitário NO/DO Campo: Contradições e Consensos no Assentamento Luís Inácio Lula da Silva, do Movimento sem Terra - MST - em Santa Cruz Cabrália - Bahia/Brasil

de novos padrões capitalistas e das novas determinações do mundo do trabalho, que passam a exigir cada vez mais dos mercados, nota-se, com base em nossa realidade, que a situação vem se agravando nos últimos anos, a partir da década de 80. Há uma cobrança quanto à oferta de produtos e serviços de qualidade, mão de obra capacitada, novas formas de organização, novas formas de gestão e o acesso à utilização de tecnologia de ponta.

Segundo Schneider (2004), o atual cenário é reflexo da avalanche de transformações sociais que o mundo sofreu em virtude da reestruturação capitalista e sua economia em escala global, a qual influenciou fortemente todos os segmentos, inclusive o mundo rural.

Trata-se dos efeitos e dos condicionantes impostos pela globalização que, sinteticamente, pode ser caracterizada, conforme definiu Castells (1999), pela excepcional capacidade da economia capitalista de ajustar, em escala planetária, a interdependência entre as condições de tempo e espaço no processo global de produção de mercadorias. Essa interdependência se expressa através da descentralização industrial, da velocidade de contato proporcionada pelas novas telecomunicações, através da integração dos capitais financeiros, comerciais, agroindustriais, etc. (SCHNEIDER, 2004, p. 90).

Obviamente que as consequências da reestruturação capitalista e seu impacto no meio rural, o que modificou radicalmente a óptica do desenvolvimento agrário, não se limitam às questões aqui apresentadas, considerando-se a gama de fatores e variáveis relacionadas ao assunto. No entanto, o objetivo deste capítulo é o de apenas contextualizar o advento do desenvolvimento no campo brasileiro, para, então, cuidar de nossa definição e tratá-lo numa abordagem territorial.

Nesta perspectiva do desenvolvimento, surgem, então, novos debates que cercam a temática do desenvolvimento também no espaço rural, que encontra destaque na agenda política mundial e tem recuperado seu espaço na literatura de vários países, inclusive do Brasil. Nestas discussões teóricas que envolvem o assunto,

[...] ressalta-se a preocupação dos estudiosos com quatro elementos-chave a partir dos quais se preconiza a retomada do debate sobre o desenvolvimento rural: a erradicação da pobreza rural, a questão do protagonismo dos atores sociais e sua participação política, o território como unidade de referência e a preocupação central com a sustentabilidade ambiental. (SCHNEIDER, 2004, p. 93-94).

Segundo Schneider (2004), um dos autores que atribuem uma nova roupagem ao desenvolvimento rural, em países em processo de desenvolvimento, é o inglês Frank Ellis 
(2001; 2000; 1998). Sua abordagem privilegia, conforme Schneider, o que ele denomina de estratégias de sobrevivência familiares e a diversificação dos modos de vida rurais (household strategies and rural livelihood diversification), preconizando que as estratégias que "geram impactos significativos na melhoria das condições de vida dessas populações e que ampliam suas perspectivas de garantir a reprodução social e econômica estão, na maioria das vezes, nas próprias localidades e territórios onde vivem" (SCHNEIDER, 2004, p. 94-95).

Para Schneider, Ellis é cauteloso, quanto a atribuir um sentido teórico à noção de desenvolvimento rural, preferindo defini-lo como um "conjunto de ações e práticas que visam reduzir a pobreza em áreas rurais, visando estimular um processo de participação que empodera os habitantes rurais, tornando-os capazes de definir e controlar suas prioridades para a mudança” (ELLIS 2000, p. 25; 2001, p. 443 apud SCHNEIDER, 2004, p. 95).

Esta nova abordagem do que seja desenvolvimento rural, que emerge dos debates e disputas sociais e políticas, está apoiada em seis mudanças básicas, todas elas assentadas nos princípios da revolução verde, outrora explicados, a partir da abordagem do desenvolvimento rural defendida pelo holandês Jan Douwe Van Der Ploeg et. al.. (2000), mais voltado ao contexto dos países desenvolvidos.

Primeiro, o reconhecimento social de que o campo pode ser muito mais do que apenas um produtor de alimentos e matérias-primas, mas também um espaço de inúmeras possibilidades, produzindo cultura, conhecimento, informação, tecnologia etc. Segundo, a necessidade de se estabelecer relações e sinergias entre diversas atividades no território rural, agrícolas e não agrícolas, trabalhando uma proposta de desenvolvimento do campo que reconheça e valorize seus recursos e distintas potencialidades de produção. Terceiro, um desenvolvimento rural que seja capaz de redefinir as relações entre os sujeitos e suas identidades, com a combinação de atividades multiocupacionais e estímulo à pluriatividade no campo. Quarto, um modelo que ressignifique o conceito de comunidade rural e suas interelações entre os sujeitos do campo e demais atores locais (proprietários de sítios de lazer, moradias secundárias, empresas, condomínios etc.). Quinto, a reestruturação do papel das políticas públicas voltadas ao campo, ultrapassando a noção clássica de um campo exclusivamente agrícola e obsoleto. Sexto, e último, considerar a necessidade de se preservar e conservar os recursos naturais, promovendo a sustentabilidade ambiental, por meio do manejo adequado dos recursos existentes. Neste sentido, segundo Ploeg et. al.. (2000, p. 395), “o desenvolvimento rural seria uma tentativa de reconstrução das bases econômicas, sociais e 
ambientais, e das próprias unidades familiares, em face das limitações e lacunas intrínsecas do paradigma produtivista".

Já o brasileiro José Eli da Veiga (2001), que focaliza as dimensões ambientais e territoriais do desenvolvimento rural no Brasil, em suas obras mais recentes, é refratário em arriscar uma definição para o desenvolvimento rural. Entretanto, destaca suas interfaces e vínculos com o conceito de desenvolvimento em geral, que na interpretação de Amartya Sen (2008), trata-se de um processo de expansão das liberdades dirigidas para os fins.

Na perspectiva da expansão das capacitações e liberdades individuais como meio e fim do desenvolvimento, Veiga (2001) aponta os seguintes objetivos máximos e elementos fundamentais do desenvolvimento rural sustentável no Brasil: a valorização e fortalecimento da agricultura familiar; a diversificação das economias e modos de fazer nas próprias localidades e territórios; o estímulo ao empreendedorismo local e as intervenções dos organismos governamentais para formação de arranjos institucionais locais.

Para uma definição do desenvolvimento rural, Veiga (1998, p. 11) caracteriza-o como um "processo sistêmico mediante o qual uma economia consegue simultaneamente crescer, reduzir desigualdades sociais e preservar o meio ambiente (acrescentando: fácil de falar, difícil de conseguir)".

Outro autor já citado neste trabalho, e que também contribuiu de forma significativa para a construção do conceito de desenvolvimento rural é Navarro (2001), o qual sugere uma distinção entre os conceitos de desenvolvimento agrícola, agrário e rural. Para o autor, o desenvolvimento agrícola está associado às condições de produção de alimentos; o agrário, relacionado à vertente da teoria marxista e sua proposta de interelação do homem com o seu ambiente natural; e o rural, aquele que destaca o papel do Estado na promoção de políticas públicas voltadas à melhoria da qualidade de vida no meio rural, de forma sustentável.

Schneider (2004, p. 98), enfim, traz a sua visão de desenvolvimento rural, definindo-o como um "processo que resulta de ações articuladas, que visam induzir mudanças socioeconômicas e ambientais no âmbito do espaço rural para melhorar a renda, a qualidade de vida e o bem-estar das populações rurais".

Outra expressão mais recente do desenvolvimento rural, e que retrata a questão da territorialidade que se pretende abordar, é a do desenvolvimento local, que surgiu em virtude da necessidade, principalmente das Organizações Não Governamentais, de delimitar sua área de intervenção social a partir de um espaço geográfico em que transcorriam as relações sociais e as atividades produtivas de um determinado grupo, entendido como 
uma resultante direta da capacidade dos atores e das sociedades locais se estruturarem e se mobilizarem, com base nas suas potencialidades e sua matriz cultural, para definir e explorar suas potencialidades e especificidades, buscando competitividade num contexto de rápidas e profundas transformações. No novo paradigma de desenvolvimento, isto significa, antes de tudo, a capacidade de ampliação da massa crítica dos recursos humanos, domínio do conhecimento e da informação, elementos centrais da competitividade sistêmica (BUARQUE, 1999, p. 14-15).

O argumento básico desses autores favoráveis ao desenvolvimento local refere-se ao fato de que é na esfera local que os problemas são mais bem identificados e, portanto, mais fáceis de serem solucionados adequadamente, de forma dialógica e participativa. $\mathrm{O}$ atendimento das necessidades da coletividade, o aproveitamento das potencialidades locais e das habilidades existentes é extremamente facilitado pela maior proximidade das pessoas. Vale destacar que o desenvolvimento local pressupõe uma organização físico-territorial.

\subsection{A Abordagem Territorial do Desenvolvimento Rural e seus Significados}

O governo brasileiro, especialmente nas esferas federal e estadual, tem adotado um enfoque territorial para a promoção de políticas públicas de desenvolvimento, especialmente no meio rural. É no campo da Geografia que o conceito de territorialidade ganha destaque, e é de onde se deve retirar sua essência. Entretanto, é preciso adequá-lo a outras ciências, a exemplo das Ciências Sociais, por onde o conceito passa por uma ressignificação. Neste sentido, segundo Gohn (2009, p. 44), o território

[...] passa a ser uma categoria ressignificada e uma das mais utilizadas para explicar as ações localizadas, mas é uma nova concepção de território distante da geografia tradicional que a confundia com o espaço físico. Território passa a se articular com a questão dos direitos e das disputas pelos bens econômicos, de um lado, e, de outro, pelo pertencimento ou pelas raízes culturais de um povo ou etnia.

Para Di Méo (1998), o território pode ser entendido como uma construção social, isto é, um processo de interação dos sujeitos com os lugares e objetos de suas vidas cotidianas. Já Claude Raffestin $(1986 ; 1987 ; 1993)$ defende que o conceito de território tem relação com o princípio da alteridade, solidariedade e ajuda mútua, ou seja, é um constructo das relações entre os sujeitos, enquanto membros de uma sociedade. 
Altemar Felberg - Autonomia e Desenvolvimento Comunitário NO/DO Campo: Contradições e Consensos no Assentamento Luís Inácio Lula da Silva, do Movimento sem Terra - MST - em Santa Cruz Cabrália - Bahia/Brasil

$\mathrm{Na}$ definição de ambos os autores, nota-se que o território tem a ver com um processo de relação tênue e direta entre o espaço e o homem, que se expressa na forma de uso e nas modificações ocasionadas pelos sujeitos, sobre a base física e natural em que se encontram.

Numa perspectiva mais político-social, outros geógrafos (SOUZA, 2003; HAESBAERT, 1997 e 2002) defendem a ideia de que o território não está limitado à noção de espaço social, onde as relações humanas e suas reproduções sociais ocorrem. Para estes, território é também um campo de forças, onde atuam e operam as relações de poder e dominação.

Aproximando-se destas definições, e transferindo-as para o ambiente da ruralidade, Abramovay (2003, p. 195) diz que:

[...] territórios podem ser definidos como lugares de interação entre sociedades humanas e ecossistemas. O território é a maneira como uma determinada sociedade se organiza em sua relação com a natureza. Esta organização supõe formas de coordenação entre organizações sociais, atores econômicos e representantes políticos, necessariamente específicas e com uma história própria a cada lugar. No meio rural a noção de território adquire uma dupla importância: em primeiro lugar, ela convida a reflexão sobre o desenvolvimento a voltar-se a um conjunto variado de protagonistas e a superar assim um âmbito estritamente setorial. A diversificação das economias rurais é, portanto, o resultado mais importante do desenvolvimento territorial em áreas não densamente povoadas. Além disso, a noção de território, no meio rural, chama a atenção ao fato de que o processo de desenvolvimento depende fundamentalmente da maneira como cada localidade vai relacionar-se com os ecossistemas em que vive.

Oportunamente, para uma melhor compreensão da abordagem territorial ao desenvolvimento rural, trazemos uma definição operacional para território, apresentado pelo Documento de Referência para um Programa Territorial de Desenvolvimento Rural Sustentável, elaborado pelo Instituto Interamericano de Cooperação para a Agricultura (IICA). No referido documento, território é entendido como:

um espaço físico, geograficamente definido, geralmente contínuo, compreendendo cidades e campos, caracterizado por critérios multidimensionais, tais como o ambiente, a economia, a sociedade, a cultura, a política e as instituições, e uma população, com grupos sociais relativamente distintos, que se relacionam interna e externamente por meio de processos específicos, onde se pode distinguir um ou mais elementos que indicam identidade e coesão social, cultural e territorial. (BRASIL, 2003, p. 4).

No Brasil, há autores que expressam cautela em formular um modelo de desenvolvimento baseado meramente no princípio da localidade ou da territorialidade, como é o caso de Graziano da Silva (2002). Este justifica sua posição, salientando que, na maioria dos 
espaços rurais brasileiros, registra-se grande debilidade e dificuldade dos atores sociais em se organizarem socialmente, configurando-se como um obstáculo ao desenvolvimento que não pode ser desconsiderado. Para o autor, a falta de participação social e econômica dos beneficiários é apresentada muitas vezes como um fato inevitável, especialmente em populações rurais, periféricas e tradicionais vulnerabilizadas historicamente, pela dificuldade do Estado brasileiro em atender as demandas levantadas pelas populações locais.

Segundo Sen (2008), reconhecidamente, a pobreza é uma grande limitadora das liberdades individuais e coletivas, prejudicando consideravelmente a capacidade de participação do indivíduo. Para o autor,

[...] a pobreza deve ser vista como privação de capacidades básicas em vez de meramente como baixo nível de renda, que é o critério tradicional de identificação da pobreza. A perspectiva da pobreza como privação de capacidades não envolve nenhuma negação da ideia sensata de que a renda baixia é claramente uma das causas principais da pobreza, pois a falta de renda pode ser uma razão primordial da privação de capacidades de uma pessoa. (SEN, 2008, p. 109).

Segundo Pinzani (2011, p. 89), “[...] o fim da pobreza pode consistir na inserção completa no sistema produtivo [...] ou na realização duma maior autonomia individual”.

A abordagem de Ellis está centrada no que ele denomina de estratégias de sobrevivência familiares e a diversificação dos modos de vida rurais, onde ele mostra que as iniciativas e ações que geram impactos significativos na melhoria das condições de vida dessas populações, em vários aspectos, e que ampliam suas perspectivas de garantir a reprodução social e econômica estão, na maioria das vezes, nas próprias localidades e territórios onde vivem. Esse desenvolvimento se dá por meio da combinação de várias iniciativas, práticas e estratégias sociais próprias da comunidade.

Com esta introdução sobre a nova perspectiva do desenvolvimento no espaço rural, com um recorte territorial, avaliado sob diferentes aspectos da vida das comunidades, é que trazemos o conceito de 'desenvolvimento comunitário rural', com as justificativas de que "a humanização do desenvolvimento passa pela reconstituição dos espaços comunitários" (DOWBOR, 198, p. 44), e de que a "reconstituição de uma humanidade organizada em torno de comunidades que se reconhecem internamente, mas que também interagem, comunicam com o resto do mundo, participam de forma organizada de espaços mais amplos" (SANTOS, 1998, p. 44). 


\subsection{Desenvolvimento Comunitário Rural: histórico, definição e características}

Para compreender o processo de construção do desenvolvimento comunitário rural no contexto brasileiro, bem como suas características, é preciso, antes de qualquer coisa, reconhecer que a nação brasileira surgiu e se desenvolveu ao compasso do processo de colonização predatória experimentado pelas terras de Vera Cruz, por ocasião da chegada de Pedro Álvares Cabral, em condições de extrema heteronomia e notadamente contrárias à democracia, cujos reflexos são percebidos até hoje na subalternidade do seu povo.

Comandante militar, navegador e explorador lusitano, creditado como o descobridor do Brasil, Cabral buscava estreitar as relações comerciais com a Índia, em detrimento do monopólio já estabelecido pelos comerciantes árabes, turcos e italianos, e ainda assegurar o retorno à Europa, com suas naus carregadas de especiarias valiosas. Nesta jornada épica, a frota comandada pelo português, composta por treze navios, não se sabe ao certo se por acaso ou não, afastou-se demasiadamente da costa africana, avistando as terras de Vera Cruz, referenciadas na Carta de Pero Vaz de Caminha, que mais tarde seriam batizadas de Brasil.

As terras "descobertas", achadas num trecho afastado da rota que os navegadores sequer sabiam da existência, tratadas como terra sem dono, sem povo, já que as criaturas que habitavam eram consideradas como inferiores e sem almas, era um prato cheio para atender aos interesses comerciais da Europa, sem qualquer constrangimento.

Sobre este processo de colonização, Freire (1977, p. 67) denuncia que foi fortemente predatório, marcado pela "exploração econômica, escravidão, concentração das terras, mandonismos, falta de liberdade de expressão e de livre iniciativa etc.”. Assim, escancaradamente, a formação da nação brasileira surgiu seguindo a proposta lusitana de exploração do Brasil, já que, claramente, não havia outra intenção que não fosse atender aos interesses comerciais, na tentativa de enriquecer os países da Europa.

Desse ranço colonial emerge a nação brasileira, miscigenada de três raças, povos historicamente escravizados e subalternizados, violados em favor de uma minoria, ainda que isógena, de portugueses e de sua cultura eurocêntrica. Para Batista (2011, p. 54), o processo de colonização não impactou apenas os povos originários do Brasil, mas, também, mais adiante, os povos surgidos com o processo de miscigenação, a exemplo dos "negros, caboclos, agricultores, escravos, ferreiros, barqueiros", denotando que a resistência dos povos oprimidos e despossuídos esteve presente ao longo da história brasileira, nos períodos colonial, monárquico e republicano, e é um dos elementos da identidade política do povo. 
As lutas travadas no campo brasileiro iniciaram-se juntamente com o processo de invasão e colonização portuguesa, uma vez que os grandes movimentos sociais se originaram dos conflitos que se acirraram em torno da luta pelo uso e ocupação da terra e contra os processos opressores marcados pela exploração, dominação e degradação dos povos colonizados - povos que sofreram não só as violências físicas do período colonial, a exemplo dos genocídios e escravidão, mas, sobretudo, as violências simbólicas do período póscolonial, como a negação dos direitos sociais e trabalhistas e a discriminação étnico-racial.

Para Freire (1983), o sistema colonial era majoritariamente autárquico, inviabilizando a participação popular e o autogoverno, requisitos necessários para que uma nação seja constituída autonomamente. "Não há autogoverno sem dialogação, daí ter sido entre nós desconhecido o autogoverno ou dele termos raras manifestações” (FREIRE, 1983, p. 70).

Dessa forma, sem abertura ao diálogo, o autocratíssimo colonial esterilizou qualquer possibilidade de participação popular na vida pública do país. Os povos indígenas, os africanos e as mulheres, em particular, eram invisíveis na sociedade e na política, ocupando espaços culturais e sociais de inferioridade, resultado da invasão cultural. Romper com esta cultura segregacionista, ainda quase cinco séculos depois, ainda se apresenta como um grande desafio da nação, sobretudo no campo das políticas públicas, que por mais avanços que tenham alcançado, ainda deixa margens a processos de exclusão.

No período imperial, o desenvolvimento social ainda rastejava, embora houvesse um movimento político intenso quanto aos rumos do país, mas esta disputa contemplava apenas os interesses de uma minoria: ou de portugueses vindos da corte, ou de brasileiros abastados, descendentes diretos de europeus. Os povos indígenas e os africanos, embora fizessem um grande esforço, ainda que não coordenado, em contribuir nas principais revoltas sociais, acompanhavam o desenrolar dos fatos sem garantias de serem contemplados pelas grandes transformações sociais defendidas. Notadamente, o modelo de colonização do país usurpou o contexto cultural dos povos subalternizados, impondo uma visão de mundo, promovendo a invasão cultural. Para Freire (1983), esta invasão cultural possui duas faces: na primeira, ela domina econômica e culturalmente, de modo a dispor e "objetificar" o invadido; na segunda, ela usurpa os valores dos invadidos, alterando-os, fazendo com que estes vejam a realidade sob a ótica do invasor. Tanto uma face quanto outra são táticas covardes de dominação, que só levam à perda da autonomia e, consequentemente, à dependência e alienação.

A invasão cultural promove o silêncio, pois ela impõe a forma de pensar do dominante sobre o dominado. Ela caminha num sentido contrário à autonomia, pois impede que as 
manifestações sejam ditas com as próprias palavras. Para Freire (1980, p. 62), há uma relação entre a dependência e a cultura do silêncio. "Ser silencioso não é ter uma palavra autêntica, mas seguir as prescrições daqueles que falam e impõem a sua voz".

Neste contexto, fica evidente que o caminho percorrido pelo Brasil, contrário à consolidação da democracia, enfraqueceu o desenvolvimento de um projeto de nação participativo, realçando a já alarmante desigualdade social e reforçando a condição de heteronomia que estes povos escravizados foram submetidos.

Ainda para Freire (1983), o processo de criação do Estado Democrático aconteceu sem que fossem consideradas as especificidades sociais resultantes da colonização exploratória de Portugal, demonstrando que a democracia não pode se resumir a uma única nuance quando se trata de um povo alienado culturalmente. Conforme o autor (p. 86-87), um dos principais problemas do Brasil é:

[...] o de conseguir o desenvolvimento econômico, como suporte da democracia, de que resultasse a supressão do poder desumano de opressão das classes muito ricas sobre as muito pobres. E de coincidir o desenvolvimento com um projeto autônomo da nação brasileira.

Hoje, o panorama cultural construído pelos especialistas em cultura, apresentado por Nussbaumer (2007), o qual traz reflexões importantes sobre o papel do Estado na produção cultural contemporânea, torna evidente que vivemos num mundo cuja característica é a multiplicidade dos signos e matérias e formas de expressão culturais.

Em todos os países, e esta tem sido uma marca importante da sociedade brasileira, cada vez mais o que prevalece são as misturas culturais, os hibridismos, as mestiçagens, como já chamavam à atenção, os tropicalistas, nos anos sessenta. Vivemos processos claros de superação das fronteiras, que antes pretensamente demarcavam os pertencimentos culturais.

As mulheres conquistaram, ao longo do século passado, o direito de problematizar as antigas fronteiras que separavam o masculino do feminino. Caminhamos, pois, para uma cultura caracterizada pela androginia e pela multiplicidade cada vez maior das formas de ser homens e de ser mulheres. Os modelos se diversificam, e se tornam cada vez mais tênues as demarcações.

Embora ainda muito arraigadas, as fronteiras que separam as etnias em nosso país também vêm sendo corroídas pela atuação política dos negros e de muitos movimentos sociais de defesa dos direitos humanos. A cultura afro-brasileira, antes reclusa aos guetos e periferias das cidades, ou folclorizada nos salões e nas praças públicas, sob o controle dos 
Altemar Felberg - Autonomia e Desenvolvimento Comunitário NO/DO Campo: Contradições e Consensos no Assentamento Luís Inácio Lula da Silva, do Movimento sem Terra - MST - em Santa Cruz Cabrália - Bahia/Brasil

brancos, ganha cada vez mais autonomia e se coloca não apenas como expressão cultural e estética diversa, mas como expressão de diferentes concepções políticas e éticas, que nascem das formas diferenciadas de ler a sociedade, que partem dos grupos subalternizados.

Este panorama sociocultural enviesado de formação da nação brasileira responde a muitas perguntas sobre a condição de subalternidade, sobretudo cultural, da nação sem voz, paternalista e machista, altamente dependente e alienada.

$\mathrm{Na}$ perspectiva apresentada aqui, fica claro que a sociedade que não busca o desenvolvimento, que não direciona os seus esforços para reconhecer a si e alcançar a sua autonomia, reforça as estruturas da heteronomia, amarradas ao longo do processo de invasão cultural. E este é o principal desafio, há cinco séculos, desde a colonização: buscar o desenvolvimento, alcançar a autonomia, poder expressar aquilo que é real, endógeno, visando romper as amarras que nos impedem de alcançar uma nação autônoma.

Segundo Silva e Arns (2002), a ideia de desenvolvimento comunitário como uma ação governamental surgiu no pós-guerra, período da história em que se deu a divisão do mundo nos blocos de capitalistas e socialistas. Conforme os autores, surgiu também no início da guerra-fria, como uma estratégia dos países capitalistas para assegurar a ordem social. A ação prática proposta para o desenvolvimento comunitário, ainda segundo os referidos autores, fundamentou-se na ideia de que "a pobreza tornava os povos receptivos à propaganda comunista e de que a ajuda aos povos subdesenvolvidos reverteria em benefícios econômicos aos Estados Unidos" (SILVA; ARNS, 2002, p.6).

Foi somente a partir dos anos 50, que a Organização das Nações Unidas (ONU) se empenhou em divulgar mais sistematicamente o desenvolvimento comunitário como um

processo através do qual cada povo participa do planejamento e da realização de programas que se destinam a elevar o padrão de suas vidas. Isso implica na colaboração indispensável entre os governos e o povo para tornar eficazes os esquemas de desenvolvimento viáveis e equilibrados (AMMANN, 1981, p. 148).

Silva e Arns (2002, p. 6) ainda revelam que o conceito de desenvolvimento começou a ganhar destaque no Brasil a partir da década de 40, com os primeiros projetos voltados ao "incremento da produção de alimentos e a educação rural e industrial", e com a criação de algumas instituições governamentais, com destaque para a Associação de Crédito e Assistência Social (ACAR), em 1948, e as Campanhas de Educação Rural (CNER) e o Serviço Social Rural, nas décadas de 40 e 50. 
Já no início da década de 60, ainda conforme os autores, a prática do desenvolvimento comunitário avançou, notadamente com o fortalecimento do Movimento de Educação de Base (MEB), originado da Igreja de Natal $(\mathrm{RN})$, órgão do Estado responsável por ministrar a educação nas comunidades e organizá-las socialmente.

A partir de 1964, com as mudanças no rumo político do país, em virtude do golpe militar, que reprimiu os movimentos sociais, é que o desenvolvimento comunitário seguiu outros caminhos, "passando ao contexto de 'integração social' que via a participação popular como meio de 'ajustar, cooptar, colaborar' com as diretrizes traçadas pelo Estado em programas que passaram a privilegiar os aspectos quantitativos do desenvolvimento". (Ibid.)

Foi a partir de então, de acordo com o II Plano Nacional de Desenvolvimento, que o desenvolvimento comunitário passou a ser visto como um

processo pelo qual os responsáveis locais são induzidos, por equipe técnica, a escolherem alternativas de desenvolvimento mutuamente coerentes e que se integrem nas diretrizes emanadas das instâncias superiores do governo (SILVA; ARNS, 2002, p. 6).

Como retratam os autores, o processo de mudança nos objetivos do desenvolvimento comunitário, dando aos seus programas nova orientação política, não se deu, entretanto, de forma pacífica. Ocorreram muitos conflitos nesta transição, principalmente devido ao fato do Serviço Social Rural não ter aceitado muito bem esta reestruturação do desenvolvimento comunitário em bases diferentes daquelas preconizadas pelo órgão, o qual concebia o desenvolvimento comunitário como uma pedagogia de participação. Diferentemente, o que predominou foi "uma concepção prática de participação e articulação que tinha como objetivo resultados estabelecidos que deixavam de fora questões estruturais do desenvolvimento" (SILVA; ARNS, 2002, p.7).

Mais adiante, na década de 1970, segundo os mesmos autores, foi que os programas de desenvolvimento comunitário foram substituídos pelo Programa Nacional de Centros Sociais Urbanos, "consolidando sua estratégia de transformar as ações de comunidades em atividades comunitárias de integração social como lazer, treinamento profissional, previdência e assistência jurídica" (Ibid.).

Seguindo esta trajetória, continua os autores, foi que a noção de desenvolvimento comunitário ficou carregada de preconceitos, uma vez que este passou a ser entendido como encobridor de "diferenças de classe e das desigualdades sociais" (Ibid.). Em resumo, o desenvolvimento comunitário foi considerado pelo governo da época como uma 
estratégia governamental de cooptação e desarticulação nos movimentos sociais. Já o serviço social passou a ser compreendido como conjunto de práticas assistencialistas, de caráter paliativo com o objetivo de encobrir as questões estruturais da dinâmica social. (Ibid.)

Por isso, pela trajetória equivocada do desenvolvimento comunitário, particularmente no meio rural, é que, para resolver as desigualdades sociais existentes neste meio, sobretudo erradicar o problema da pobreza, o desenvolvimento rural deve ser uma prioridade, segundo Weigand Jr. et al. (2003, p. 8-9). Na visão dos autores,

A experiência nacional e internacional dos organismos de promoção do desenvolvimento em áreas rurais tem mostrado apenas insucessos e sucessos limitados. Apesar de mais de 50 anos de ações de organismos internacionais de promoção do desenvolvimento em áreas rurais, o número de pobres rurais ainda cresce, e a proporção de pobres nas áreas rurais é maior que nas áreas urbanas. A diferença de renda entre populações rurais e urbanas é agravada ainda pela falta de oportunidades e de acesso a educação e saúde.

Todavia, ainda de acordo com os autores, apesar de todas as dificuldades enfrentadas na tentativa de promoção do desenvolvimento comunitário rural, com seus sucessos e insucessos, as estratégias adotadas no sentido de promover o desenvolvimento em territórios fragilizados "têm mostrado que a participação das populações locais no diagnóstico dos problemas, e no planejamento e implementação de soluções torna as políticas e programas de desenvolvimento mais eficazes" (WEIGAND JR. et al., 2003, p. 9). Segundo os autores, "programas de desenvolvimento em que as populações locais participam encontram melhor aceitação, utilizam melhor os recursos locais e lidam mais frequentemente com os problemas mais importantes para as populações locais” (Ibid.). Nesta perspectiva, Silva e Arns (2002, p. 8), utilizando-se da metáfora do "casulo", dizem que o desenvolvimento comunitário pode ser entendido como:

[...] o processo através do qual a comunidade amadurece em relação a si mesma e a seus potenciais, rompe seus casulos e se transforma em novas possibilidades de ser. A comunidade pré-existe ao técnico ou ao programa. Para o bem e para o mal, sua história, sua trajetória, seus significados, nos precedem, configurando cada uma delas como ser único.

Neste contexto de transformação, os autores destacam que, assim como a borboleta rompe seu casulo e alça voo, da mesma forma a comunidade tem a capacidade de amadurecer, de definir e controlar suas próprias prioridades para a mudança rumo a um modelo de desenvolvimento real, sustentável, justo e igualitário. 
O sentido de comunidade a que nos referimos, trata-se de "uma relação social quando e na medida em que a atitude na ação social repousa no sentimento subjetivo dos participantes de pertencer (afetiva ou tradicionalmente) ao mesmo grupo" (WEBER, 1972, p. 25). Segundo Bauman (2003, p. 15-16), “é um sentimento recíproco e vinculante - a vontade real e própria daqueles que se unem; e é graças a esse entendimento e somente a esse entendimento, que na comunidade as pessoas permanecem essencialmente unidas a despeito de todos os fatores que as separam”. Essa ideia é corroborada por Areca, sujeito desta pesquisa:

Não é que o líder vai interferir assim no que a comunidade quer fazer, não é uma interferência, há sim uma orientação, agora você pode, a sua vida é a sua vida, se nós buscamos pela independência, né, $(++) \ldots$ agora depende também do que você vai atrapalhar [...] (ARECA, excerto extraído do Grupo Focal $\mathrm{n}^{\circ}$ 01, realizado em maio de 2016, p. 9-10).

Ainda conforme Bauman (2003, p. 19), este tipo de comunidade, constituída a partir de um pacto social, como o que caracteriza as áreas de assentamento, "nunca será imune à reflexão, contestação e discussão" permanentes. Vimos, na pesquisa, que esse pacto social é selado entre assentados e lideranças, na forma de regimento, após ampla discussão em assembleia, como destacado nos relatos abaixo:

[...] porque aqui tem tipo um papel, o que deve e o que não pode, tipo assim, um documento de regimento falando tudo o que pode e não pode, aí você entra nas normas daquele documento e faz só o certo, porque se você sai fora da norma, você tá desrespeitando a nossa coordenação (MACAÚBA, excerto extraído do Grupo Focal n ${ }^{\circ}$ 02, realizado em maio de 2016, p. 8).

Em assembleia (++) tem algumas coisas que tem atas registradas que tudo que não pode aqui, por exemplo, quem mora aqui, pegar sua casa e alugar pra outra pessoa que vem de fora, que a gente nem conhece, aí não pode, porque vai trazer um monte de problema pra gente, trazer filhos com problemas com drogas, com roubo, com uma série de coisas, aí a gente não aceita (GUARIROBA, excerto extraído do Grupo Focal n ${ }^{\circ}$ 01, realizado em maio de 2016, p. 10).

Bauman (2003) também afirma que a comunidade de entendimento comum, mesmo que alcançada e efetivada, permanecerá sempre frágil, suscetível e vulnerável, exigindo a constância de forças atuantes no sentido de vigiar, reforçar e defender sua ordem e organicidade. 
Altemar Felberg - Autonomia e Desenvolvimento Comunitário NO/DO Campo: Contradições e Consensos no Assentamento Luís Inácio Lula da Silva, do Movimento sem Terra - MST - em Santa Cruz Cabrália - Bahia/Brasil

Podemos considerar que as acepções de desenvolvimento rural e desenvolvimento comunitário coadunam para a construção do que se entende por desenvolvimento endógeno, que traz em seu significado a questão da territorialidade.

Dessa forma, segue abaixo um quadro com as principais características e implicações deste tipo de desenvolvimento, que nasce no seio da comunidade, a partir das inter-relações entre os sujeitos e demais atores sociais e políticos:

Quadro 01 - Principais características do desenvolvimento

\begin{tabular}{|c|c|}
\hline Características & Implicações \\
\hline $\begin{array}{l}\text { Primazia do particular e do } \\
\text { específico. }\end{array}$ & $\begin{array}{l}\text { Reconhecimento de que cada região, cada colectividade, tem } \\
\text { potencialidades e problemas próprios. } \\
\text { Definição do desenvolvimento como processo múltiplo, vindo } \\
\text { "de baixo", e não como resultado de políticas centralizadas e } \\
\text { uniformes. } \\
>\begin{array}{l}\text { Perspectiva do desenvolvimento como um processo que se } \\
\text { baseia na acção dos actores locais e na valorização dos recursos } \\
\text { das colectividades. }\end{array}\end{array}$ \\
\hline $\begin{array}{l}\text { Predominância da acção e da } \\
\text { auto-organização dos actores } \\
\text { locais. }\end{array}$ & $\begin{array}{l}>\text { Valorização dos actores locais mais do que dos instrumentos e } \\
\text { das políticas. } \\
>\text { Reforço das estratégias de informação, de formação e de } \\
\text { comunicação. } \\
>\text { Importância da coordenação entre as iniciativas e projectos dos } \\
\text { actores locais, numa perspectiva de interacção e sinergia. } \\
>\text { Promoção de estratégias de auto-organização dos actores em } \\
\text { torno de iniciativas, empreendimentos e projectos comuns ou } \\
\text { convergentes. }\end{array}$ \\
\hline $\begin{array}{l}\text { Tónica na valorização dos } \\
\text { recursos qualitativos locais. }\end{array}$ & $\begin{array}{l}\text { Estímulo prioritário à qualificação profissional, à investigação } \\
\text { (ligação às Universidades locais/regionais) e à inovação. } \\
\text { Valorização da empresa e do espírito de empreendimento, de } \\
\text { risco, de experimentação, de avaliação e de acompanhamento } \\
\text { das acções e iniciativas. } \\
>\text { Ênfase nas relações interactivas (redes, comunicações, } \\
\text { informação). }\end{array}$ \\
\hline $\begin{array}{lr}\text { Perspectiva } & \text { do } \\
\text { desenvolvimento como um } \\
\text { processo participado } \\
\text { negociado. }\end{array}$ & $\begin{array}{l}\text { Transferência de poder do nível central para os níveis local e } \\
\text { regional. } \\
>\text { Aumento da capacidade de iniciativa, de organização e de } \\
\text { representação da colectividade face aos poderes públicos. } \\
\text { Criação de hábitos e práticas de partenariado, ou seja, de } \\
\text { cooperação contratual entre os parceiros locais em torno de } \\
\text { projectos comuns. }\end{array}$ \\
\hline
\end{tabular}

FONTE: NÓVOA et. al. (1992, p. 23)

As características apresentadas acima são muito bem representadas nos relatos dos sujeitos da pesquisa, deixando claro o perfeito alinhamento entre a teoria de Nóvoa (1992) e a práxis vivenciada no Assentamento Lulão: 
Altemar Felberg - Autonomia e Desenvolvimento Comunitário NO/DO Campo: Contradições e

Consensos no Assentamento Luís Inácio Lula da Silva, do Movimento sem Terra - MST - em Santa

Cruz Cabrália - Bahia/Brasil

\begin{tabular}{|c|c|}
\hline \multicolumn{2}{|c|}{ Quadro 02 - Principais características do desenvolvimento no Lulão } \\
\hline Características & Relatos \\
\hline $\begin{array}{l}\text { Primazia do particular e do } \\
\text { específico. }\end{array}$ & $\begin{array}{l}\text { Uma prova viva nós convive aqui, por nós ter todas essas obras que } \\
\text { nós temos aqui. É através do coletivo, porque se nós não tivesse esse } \\
\text { coletivo, essa união de buscar, de enfrentar, fazer ali um mutirão, } \\
\text { uma tarefa, com certeza não conseguiria toda essa estrutura que hoje } \\
\text { nós temos; é devidamente esse esforço desse coletivo... se cada um } \\
\text { conscientizar, a força que tem o coletivo, com certeza a gente se } \\
\text { avançava muito mais (ARICURI, excerto extraído do Grupo Focal no } \\
01 \text {, realizado em maio de } 2016 \text {, p. } 6 \text { ). }\end{array}$ \\
\hline $\begin{array}{l}\text { Predominância da acção e da } \\
\text { auto-organização dos actores } \\
\text { locais. }\end{array}$ & $\begin{array}{l}\text { Eu participo da juventude, eu e ele, né ((apontou para outro } \\
\text { sujeito))... temos um grupo da associação que tem o presidente, o } \\
\text { tesoureiro, a secretária né, a vice, então tem outras partes que a gente } \\
\text { participa (+) de viagens... E no caso, assim, eles sempre estão } \\
\text { participando com a gente, na escola também eles sempre vêm aqui na } \\
\text { escola, a gente também já trabalha dentro do assentamento, junto } \\
\text { com a escola, ajudando, participando, se precisasse mesmo antes da } \\
\text { gente trabalhar aqui, a gente vinha e ajudava... (BABAÇU, excerto } \\
\text { extraído do Grupo Focal } n^{\circ} 02 \text {, realizado em maio de } 2016, \text { p. } 3 \text { ). }\end{array}$ \\
\hline $\begin{array}{l}\text { Tónica na valorização dos } \\
\text { recursos qualitativos locais. }\end{array}$ & $\begin{array}{l}\text {... a diretora sempre vem nos ajudando, sempre correndo atrás pra } \\
\text { ajudar a gente, e a gente sempre teve a ajuda dela, sabe, em tudo. } \\
\text { Então }(+) \text { eu mesmo tenho que agradecer muito a ela, porque ela me } \\
\text { ajudou muito, assim que eu cheguei... Então eu não tenho o que falar } \\
\text { mal de nenhum deles aqui, porque eles todos me ajudou bastante, } \\
\text { então eu tenho é mais que falar bem deles (MACAÚBA, excerto } \\
\text { extraído do Grupo Focal n }{ }^{\circ} 02 \text {, realizado em maio de } 2016 \text {, p. } 3 \text { ). }\end{array}$ \\
\hline $\begin{array}{lr}\text { Perspectiva } & \text { do } \\
\text { desenvolvimento como um } \\
\text { processo participado } \\
\text { negociado. }\end{array}$ & $\begin{array}{l}\text { Ela é importante pela tomada de decisão, então é em uma assembleia } \\
\text { que você decide, que você define o rumo do assentamento, né, então } \\
\text { é com a comunidade, é ela quem vai dizer ou sim ou não, então a } \\
\text { assembleia é muito importante, porque é a unificação da comunidade } \\
\text { (ARECA, excerto extraído do Grupo Focal no } 01 \text {, realizado em maio } \\
\text { de } 2016, \text { p. 5). }\end{array}$ \\
\hline
\end{tabular}

\subsection{Indicadores de Desenvolvimento do Assentamento Luís Inácio Lula da Silva}

O Assentamento Luiz Inácio Lula da Silva (Lulão), caracterizado com detalhes no primeiro capítulo, fica localizado no Município de Santa Cruz Cabrália, Território Costa do Descobrimento, Extremo Sul do Estado da Bahia, às margens da rodovia BR 367.

O avanço das transformações demográficas e econômicas na região onde está localizado o Lulão é consequente da inauguração do trecho da BR-367, ligando a cidade de Porto Seguro (BA) até a rodovia BR-101, o que provocou a explosão turística da região, em 1980, tornando-a um lugar de recomeço para diversas famílias vitimadas pela crise da vassoura de bruxa, na Costa do Cacau. 
Com a instalação de grandes indústrias na região, em meados da década de 90 , ocorreu o êxodo rural, e assim as populações locais ficaram expostas aos problemas sociais decorrentes deste processo, resultando na exclusão destes grupos, das atividades econômicas emergentes, ou na inclusão precária de integrantes das comunidades em cargos temporários e de baixa remuneração, no mercado local. Assim, no que diz respeito às condições socioeconômicas dos municípios da região, a maioria da população é formada por famílias de baixa renda, que sofrem com o desemprego ou vivem de subempregos e do trabalho assalariado.

O Município de Santa Cruz Cabrália, de acordo com dados do Instituto Brasileiro de Geografia e Estatística (IBGE), possui área de $1.459 .832 \mathrm{~km} 2$ e população de 26.264 habitantes, podendo chegar a 28.226, segundo estimativa realizada para 2015, dos quais 4.493 encontram-se em situação de extrema pobreza, significando que $17,1 \%$ da população municipal vivia nesta faixa social (IBGE: 2010). O Município possui IDH de 0,654 (IDHM 2010, PNUD) e índice de GINI de 0,58.

Ainda conforme dados do último Censo Demográfico, em 2010, o valor do rendimento nominal médio mensal dos domicílios particulares na zona rural é de $\mathrm{R} \$ 968,52$, e a taxa de analfabetismo das pessoas de 10 anos ou mais era de 14,3\% - dados gerais que notadamente não representam a singularidade socioeconômica e cultural das comunidades que compõem o Município. Interessou-nos, nesta pesquisa, portanto, atribuir um índice de desenvolvimento para o Assentamento Luiz Inácio Lula da Silva (Lulão), a partir de índices já existentes (a exemplo do IDHM), acrescidos de indicadores específicos nas áreas de Educação, Saúde, Qualidade de Vida, Economia e Organização Social, extraídos da pesquisa de campo realizada em 12 de Outubro de 2015, cujos resultados apresentaremos a seguir:

\section{Fotografia 04 - Entrada do assentamento Lulão}

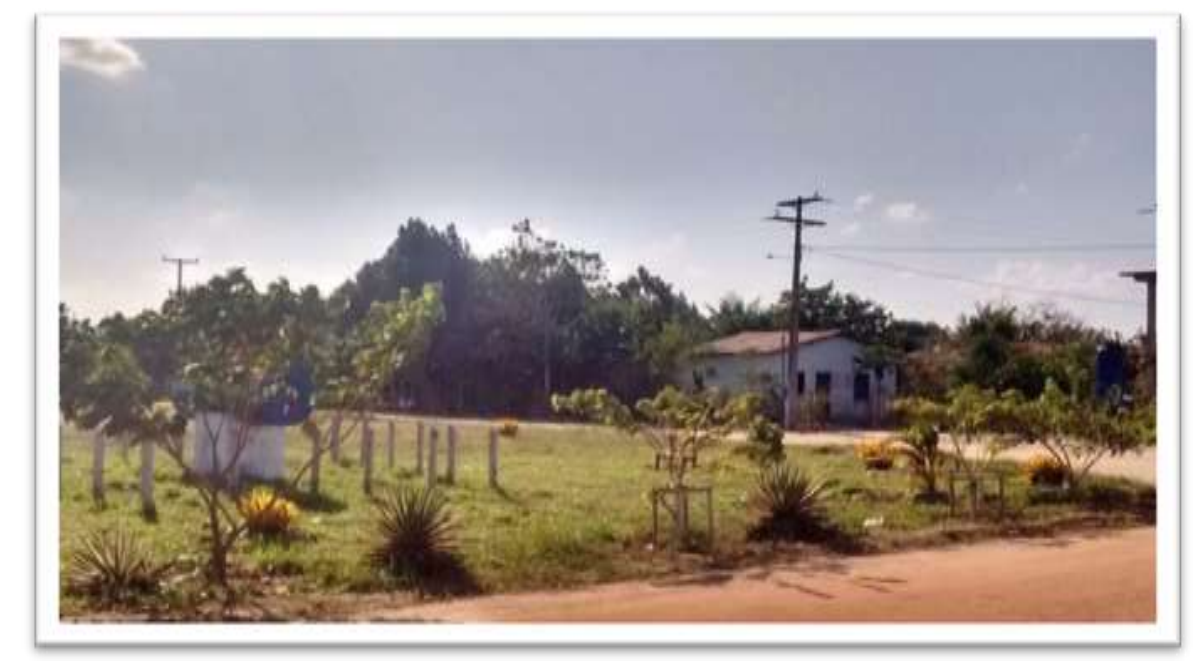


O Assentamento Luiz Inácio Lula da Silva possui 57 famílias $\operatorname{assentadas}^{23}$ e uma população estimada em 228 habitantes (média de 04 pessoas por família), que vivem sob um sistema de moradia organizado em Agrovila, possuindo, cada assentado, uma área de produção individual de 5,00 hectares (3,4 de terra livre e 1,6 de reserva legal) e a possibilidade de participação em atividades coletivas de produção. Possui uma agroindústria de beneficiamento de frutas, inaugurada em 2014, mas ainda não funcionando plenamente, resultado da participação da Associação em um Edital lançado em 2013, pela Veracel Celulose S.A, em parceria com o Governo do Estado da Bahia.

\section{Fotografia 05 - Agroindústria de beneficiamento de frutas}

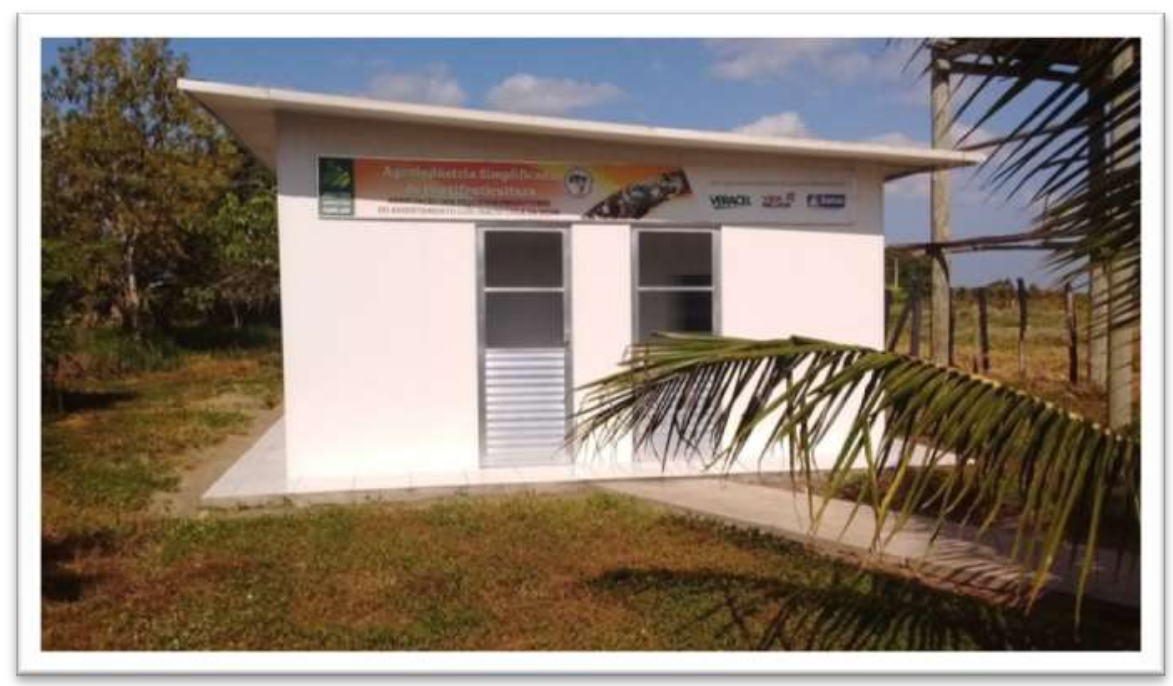

Além do cultivo e beneficiamento de frutas, aproximadamente 25 pessoas vivem da comercialização de verduras, nas feiras locais de Eunápolis, Coroa Vermelha e Cabrália.

Na comunidade é possível encontrar: 02 Bares (Bar do Grilo e Bar do Gilvan), 02 Vendas (Venda da Maria e Venda do Grilo), 01 Igreja Católica (São José), 01 Igreja Evangélica (Assembleia de Deus), 01 Escola (Escola Municipal Paulo Freire), 01 Padaria (Magnólia Cerqueira) e 01 Posto de Saúde em construção. A comunidade possui venda de produtos e serviços de forma autônoma, com visitas domiciliares, como a oferta de roupas e acessórios, produtos da Avon e Natura, bijuteria, serviços de manicure e cabeleireira etc.

Quanto à atividade agropecuária, pesqueira e de extração, é possível identificar na comunidade: a criação de gado leiteiro, sendo o produto (leite in natura) comercializado fora da comunidade; a piscicultura, sendo o produto comercializado na comunidade e fora dela; e a

${ }^{23}$ Segundo dados da Secretaria Municipal de Saúde / Unidade Básica de Saúde (2016) 
criação de porco, galinha, ganso, codorna, marreco e pato, todos utilizados apenas para consumo próprio das famílias. Além da criação de animais, os moradores do Lulão vivem da agricultura familiar, cultivando, individualmente, culturas de subsistência como: banana, mandioca, pimenta do reino, milho, feijão, grãos em geral e horticultura.

Já as plantações de café colonial sequeiro e árvores frutíferas (goiaba, banana, manga, maracujá, abacaxi e açaí), são de natureza coletiva, viabilizadas por intermédio da implementação de projeto financiado pela Fundação Banco do Brasil e Banco Nacional de Desenvolvimento Social (BNDES). Neste projeto de produção coletiva, 09 hectares são destinados ao cultivo de café colonial, em regime sequeiro, 53 hectares destinados a áreas de pastagens, a exemplo da palma, e 06 hectares para plantio irrigado de goiaba, banana, manga, maracujá, abacaxi e açaí, produtos a serem utilizados futuramente, pela agroindústria.

\section{Fotografia 06 - Cozinha de doces e compotas}

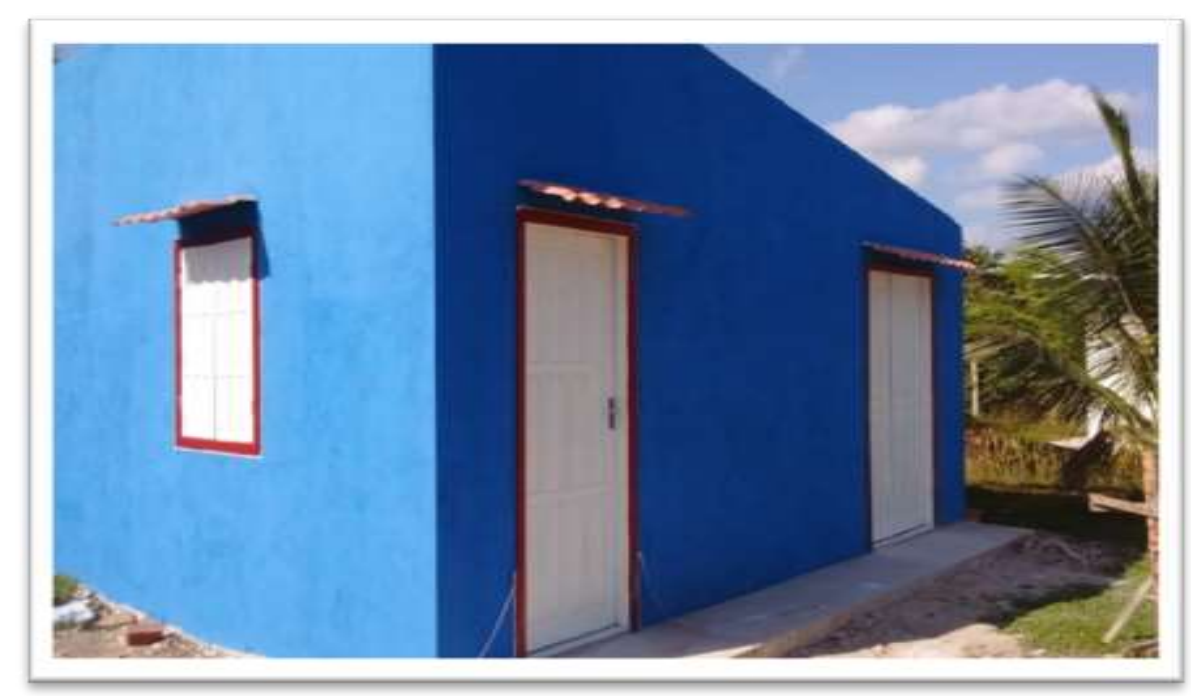

Na comunidade ainda é possível encontrar pessoas que trabalham com a extração da piaçava ou que pescam artesanalmente, para sustento da família, nas águas do Rio Ipiranga e Riacho Grande ou em uma das 09 represas existentes na propriedade do Assentamento.

Atualmente, segundo Jazian Santos (2015), o assentamento vive um momento de transição da agricultura convencional para uma agricultura agroecológica, embora alguns assentados ainda apresentem resistências às novas tecnologias de produção, alegando, especialmente, a falta de conhecimentos técnicos na área, além da ausência de assistência técnica.

Com o objetivo de incentivar a prática da agroecologia no Assentamento e atender às necessidades dos assentados, a direção do MST firmou parceria com o Centro de Estudos e Pesquisas em Emergências e Desastres em Saúde (CEPDES), no sentido de desenvolver um 
projeto-piloto de lotes agroecológicos, com 15 assentados, visando incentivar a prática na comunidade e referenciar outras iniciativas voltadas à produção agroecológica.

Ainda segundo Santos (2015), este grupo vem sendo constantemente capacitado na área, e participando de intercâmbios com outros assentados do Estado da Bahia, com o objetivo de trocar experiências e compartilhar conhecimentos em agroecologia, além de contarem com assistência técnica permanente, assegurada pelo CEPEDES.

Para o presidente da Associação, embora o assentamento já tenha quase 10 anos, os assentados ainda não conseguiram acessar o crédito para produção agrícola, no Programa Nacional de Fortalecimento da Agricultura Familiar (PRONAF), mas isso não tem sido fator limitante para que os mesmos produzam em seus lotes, tendo hoje muita produção de banana, mandioca, hortaliças, milho, feijão, café, dentre outras culturas.

No que se refere aos programas de qualificação profissional existentes no local, a comunidade informou que já foi beneficiada pelo SENAR, no ano de 2007, com os Cursos de Piscicultura, Vaqueiro, Galinha Caipira, Apicultura e Derivados da Mandioca. Já o SEBRAE ofereceu o Curso de Cultura e Cooperação, e a EMBRAPA desenvolveu um programa de qualificação profissional sobre a época de Plantio e Indução Floral do Abacaxizeiro, no Assentamento Imbiruçu de Dentro, no ano de 2004.

Concernente à estrutura de comunicação, a comunidade possui Internet via rádio (Intranet e Braz Ford), serviço da TV SKY, Embratel, GVT e Claro. Também possui sinal de celular, das Operadoras TIM, VIVO, OI e Claro, sendo este sinal acessível em alguns pontos da comunidade. Não possui telefone público, sinal de telefone fixo, serviço de correios e nem caixa postal. Os moradores sintonizam as rádios locais: Rádio Porto Brasil FM (88.7), de Porto Seguro, Rádio Cidade FM (97.5), de Porto Seguro / Santa Cruz Cabrália, e Rádio Arraiana FM (104,9), de Porto Seguro / Arraial D’Ajuda.

Todos os moradores da comunidade possuem energia elétrica. Esta se encontra instalada na comunidade desde 2009, graças ao Programa Luz para Todos, do Governo Federal. Cada família assentada foi beneficiada com 02 padrões de energia, sendo 01 instalado na casa e outro no lote individual. A Companhia de Eletricidade do Estado da Bahia (COELBA) é responsável pela distribuição e manutenção da rede. Os moradores informaram que não ocorrem picos de energia e nem a falta da mesma, tendo um valor médio de aproximadamente $\mathrm{R} \$ 100,00$ reais de consumo.

$\mathrm{Na}$ área da saúde, o atendimento à população local é realizado em uma casa localizada na Agrovila, que foi modificada para atender provisoriamente às necessidades da comunidade, 
até que a construção da Unidade Básica de Saúde (UBS) seja concluída. O atendimento é realizado 03 vezes na semana (quarta-feira, quinta-feira e sexta-feira), por uma equipe formada por 01 Médico, 01 Enfermeira, 02 Técnicos de Enfermagem, 01 Auxiliar de Serviços Gerais, 01 Agente Comunitário de Saúde (Endemias) e 01 motorista. Atualmente a estrutura do pronto atendimento é composta por 01 carro, locado pela Secretaria Municipal de Saúde de Santa Cruz Cabrália, 01 sala de recepção, 01 sala de vacina, 01 sala do consultório, 01 farmácia, 01 sala de triagem e 01 banheiro.

Fotografia 07 - Unidade básica de saúde - PSF 11 Lulão

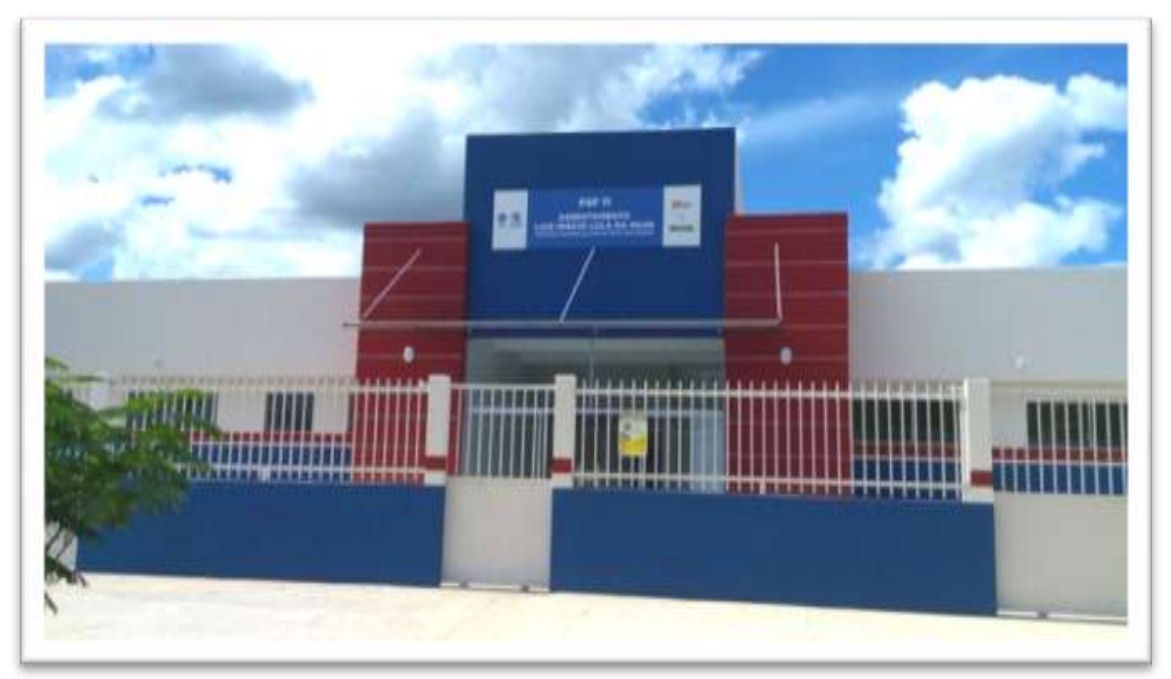

A equipe presta os seguintes serviços à comunidade: Acolhimento; Acompanhamento da Gestante e do Bebê (Pré-natal e Puericultura); Curativo, Dispensação de Medicamentos Básicos; Dispensação de Preservativos e Contraceptivos; Consulta de enfermagem; Consulta médica; Exame preventivo (câncer de colo de útero); Grupo de educação em saúde; Imunização (vacinas); Nebulização; Planejamento familiar; Teste de gravidez (TIG); Marcação de exames e consultas especializadas; Triagem neonatal e pré-natal (teste do pezinho e teste da mamãe); NASF (Núcleo de Apoio à Saúde da Família); Consulta odontológica; Tratamento Odontológico e Ultrassom, 01 vez ao mês.

Existem, ainda, as campanhas de vacinação, dengue, meningite, febre amarela, cólera, DSTs, HIV, Sífilis, Hepatite, Saúde Bucal, Saúde da Família, Orientação Sexual, Alimentação Saudável, Saúde da Gestante. Todas as campanhas são realizadas pela equipe do posto de atendimento, localizado na comunidade.

O lazer, diversão e socialização na comunidade ficam por conta de 02 Bares (Bar do Grilo e Bar do Gilvan), 02 Vendas (Venda da Maria e Venda do Grilo), 01 Igreja Católica 
(São José), 01 Igreja Evangélica (Assembleia de Deus), além de 01 Campo de Futebol de Areia, 01 Campo de Futebol Gramado e 01 quadra poliesportiva que se encontra em fase de construção, em área próxima à Escola. Como costume tradicional, a comunidade comemora o dia do Padroeiro, São José Operário, no dia 01 de Maio, além da criação do Assentamento, no dia 23 de setembro.

A comunidade possui uma Escola denominada Escola Municipal Paulo Freire, criada em 2006, subordinada à Secretaria de Educação de Santa Cruz de Cabrália e vinculada ao setor de educação do MST, atendendo à política, diretrizes e linhas pedagógicas das escolas do Movimento, onde se registra 265 alunos matriculados e frequentando, assim distribuídos: 209 alunos matriculados no Pré-escolar, Fundamental I ( $1^{\circ}$ a $5^{\circ}$ ano $)$ e Fundamental II $\left(6^{\circ}\right.$ a $9^{\circ}$ ano), nos períodos da manhã (07h30min/11h30min) e tarde (13h00min/17h00min); 56 jovens e adultos no período noturno $(18 \mathrm{~h} 20 \mathrm{~min} / 21 \mathrm{~h} 30 \mathrm{~min})$, atendidos pelo Programa EJA, com o $1^{\circ}$ e $2^{\circ}$ ciclos do Ensino Médio. Ainda, 34 alunos se locomovem para o distrito de Vera Cruz para estudarem o Ensino Médio.

\section{Fotografia 08 - Escola Municipal Paulo Freire}

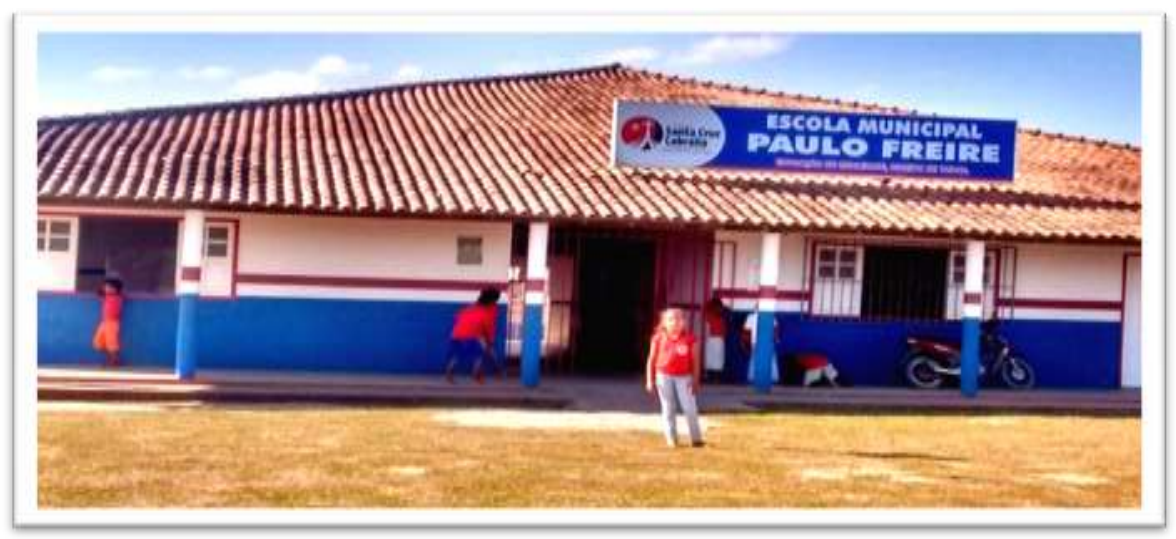

A equipe da Escola é formada por 10 professores, 03 merendeiras, 03 serventes, 03 vigias, 01 diretor, 01 vice-diretor, 01 coordenador, 02 inspetores e 01 secretária. A estrutura da escola é formada por 06 salas de aula, 01 sala da secretaria, 01 sala da direção, 01 sala da biblioteca, 01 cozinha, 01 almoxarifado, 03 banheiros masculino, 03 banheiros feminino, 01 banheiro para deficiente e 01 banheiro para funcionário.

O transporte dos alunos é realizado por 02 microônibus e 02 ônibus, que locomovem as crianças da própria comunidade, do acampamento Macadame, Trancoso, Vera Cruz e fazendas próximas ao Assentamento, transportando cerca de 170 crianças no período da manhã (06h30min / 12h00min) e no período da tarde (12h30min /17h45min).

Aos 34 alunos que fazem o Ensino Médio no Povoado de Vera Cruz, Município de Porto Seguro, também é disponibilizado transporte escolar. 
Em seu Projeto Político Pedagógico (PPP), que contempla uma educação diferenciada, a escola desenvolve projetos de agroecologia, água, lixo etc., além de encontros dos semterrinha ${ }^{24}$, realizados por meio de oficinas, pelos próprios alunos do Ensino Fundamental II.

Para Jazian Santos (2015, p. 28), a história da Escola Paulo Freire se confunde com a própria história do Assentamento Lulão, pois se trata de uma escola construída pela força coletiva, onde "os seus sujeitos se formam e se reformam a cada dia, na perspectiva da luta". Isso é demonstrado no PPP da escola:

Um dos fatores que contribuíram e continuam contribuindo no bom andamento e crescimento da escola é a participação e o envolvimento dos pais/mães e toda comunidade no trabalho coletivo, a Associação de Pais e Mestres, e na organização dos eventos festivos da escola, buscando implementar um dos nossos princípios que é o reconhecimento de que a escola está dentro do assentamento, bem como o assentamento está dentro da Escola. Ressaltamos também o envolvimento direto da Associação do Assentamento que é uma grande parceira da escola. (PPP, Escola Municipal Paulo Freire, p. 09).

Toda a organização social, política e econômica do Assentamento são gestadas pela Associação dos Pequenos Produtores Rurais do Assentamento Luís Inácio Lula da Silva ${ }^{25}$.

Registra-se que todas as conquistas do Assentamento são fruto dessa luta coletiva e foram viabilizadas por meio da associação representativa local, com destaque para: a aquisição de itens de mecanização agrícola (trator, carroça e roçadeira) junto ao INCRA; o acesso ao crédito para a compra de vacas leiteiras; a construção da unidade básica de saúde (PSF Lulão), que atende o assentamento e as comunidades vizinhas; a construção da estrutura física da Escola Municipal Paulo Freire, que atende a crianças, adolescentes, jovens e adultos do assentamento e comunidades vizinhas; a aprovação da construção da quadra poliesportiva; a construção da sede comunitária da associação; a construção da Agroindústria Simplificada de Hortifruticultura; a construção da cozinha comunitária de doces e compotas; a implantação da unidade de abastecimento e tratamento de água, com a perfuração do poço artesiano, melhorando o abastecimento de água na comunidade; a instalação da energia elétrica para todas as famílias do assentamento; a construção e ampliação de unidades habitacionais, dentre outras conquistas.

\footnotetext{
${ }^{24}$ Sem Terrinha é uma expressão que identifica as crianças vinculadas ao MST. O nome surgiu por iniciativa das crianças que participaram do Primeiro Encontro Estadual das Crianças Sem Terra de São Paulo, em 1997 (CALDART, 2003, 78)

${ }^{25}$ Organização da sociedade civil sem fins lucrativos, inscrita no CNPJ sob o $n^{\circ} 08.239 .528 .0001-20$, fundada no dia 01 de março de 2006 e registrada no dia 07 de agosto de 2006, tendo como o seu representante legal, o Sr. Antônio Pestana Lima.
} 
No que diz respeito à relação da comunidade com o meio ambiente, o Assentamento Lulão possui áreas de preservação da Mata Atlântica e áreas de Reserva Legal, onde tem um núcleo de gestão ambiental com 17 mulheres, as quais são beneficiadas pelo Programa Bolsa Verde, um Programa de Apoio à Conservação Ambiental, lançado em setembro de 2011, que concede a cada trimestre um benefício de $\mathrm{R}$ \$ 300,00 às famílias em situação de extrema pobreza, que vivem em áreas consideradas prioritárias para conservação ambiental.

A água na comunidade é captada através de dois poços artesianos, sendo 01 perfurado a $63 \mathrm{~m}$ de profundidade e o outro perfurado a $126 \mathrm{~m}$. A mesma é armazenada em 03 caixas d'água centrais, de 40 mil litros cada, sendo a água distribuída por gravidade, via encanamento para todas as residências da comunidade. O Assentamento ainda possui 13 nascentes d'água em suas áreas de preservação e conservação ambiental.

\section{Fotografia 09 - Unidade de tratamento e abastecimento de água}

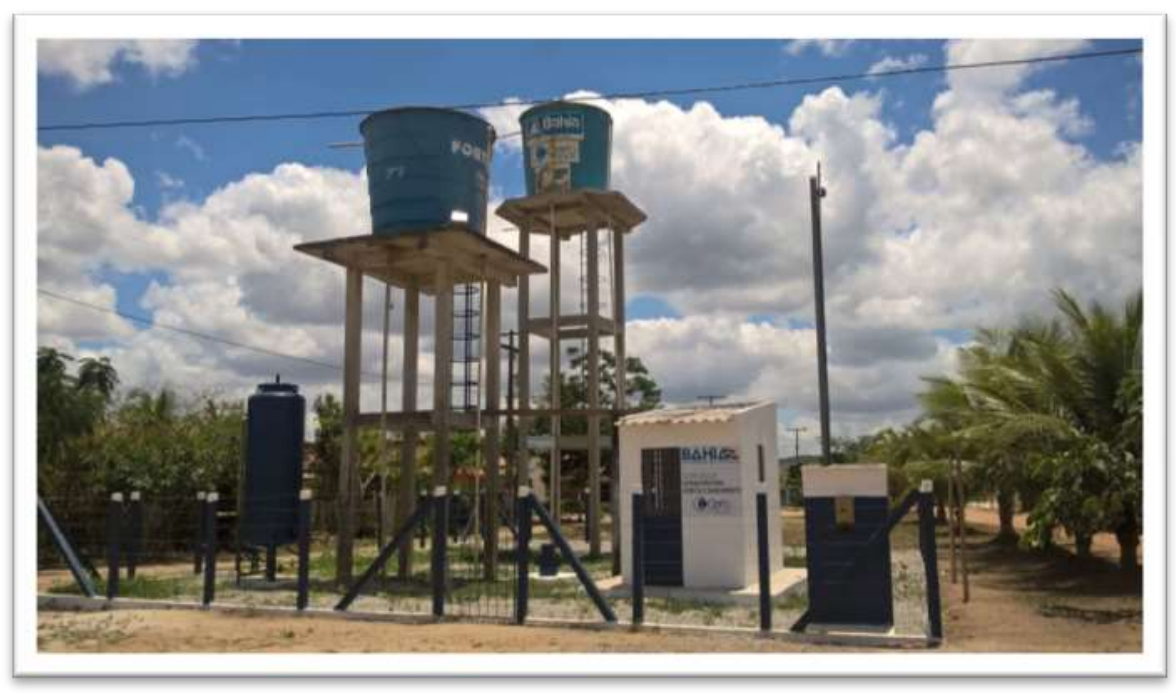

Segundo relatos dos moradores, a água não é boa para o consumo humano, pois apresenta ferrugem em sua composição, de acordo com a última análise de potabilidade realizada há mais ou menos 02 anos. Conforme relatos dos entrevistados, e como está comprovado no gráfico a seguir, questão 3.6.3 (acesso das famílias à água potável), há insuficiência de água potável para atender à demanda local, visto que o poço não está mais comportando a demanda dos moradores da comunidade, necessitando de ampliação.

Todos os moradores possuem fossa séptica em suas residências, e no que diz respeito à destinação dos resíduos, a comunidade não possui aterro sanitário, e não existe coleta de lixo por parte da Prefeitura. Sendo assim, os moradores realizam a queima do seu resíduo nos quintais, sendo feito sem qualquer prevenção e cuidado, poluindo o solo e o meio ambiente. 
Altemar Felberg - Autonomia e Desenvolvimento Comunitário NO/DO Campo: Contradições e Consensos no Assentamento Luís Inácio Lula da Silva, do Movimento sem Terra - MST - em Santa Cruz Cabrália - Bahia/Brasil

\section{Gráfico 13 - Relação com o meio ambiente}

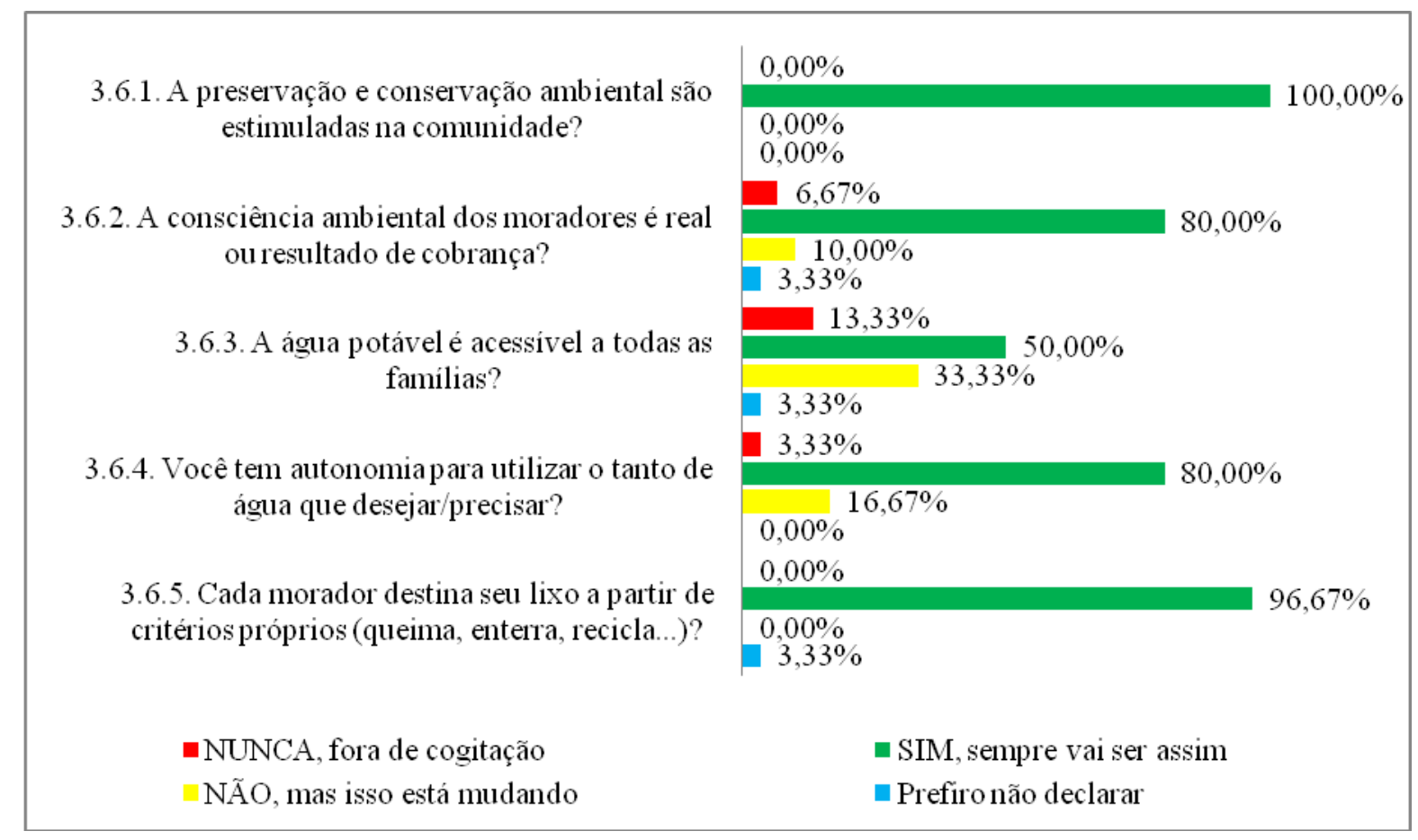

Assim, com base nestes dados e informações coletados no Assentamento Lulão, já é possível atribuir a ele um índice de desenvolvimento comunitário, ou melhor, mensurar seu grau de vulnerabilidade social. É o que veremos no quadro a seguir:

Quadro 03 - Índice de desenvolvimento comunitário rural do Assentamento Lulão

\begin{tabular}{|c|c|c|c|c|c|c|c|c|c|c|c|c|c|c|}
\hline ID & \multicolumn{2}{|c|}{ COMUNIDADE } & MUNICÍPIO & \multicolumn{11}{|c|}{ IDH 2012} \\
\hline 1 & & $\begin{array}{l}\text { ntamento } \\
\text { ulão" }\end{array}$ & $\begin{array}{c}\text { Santa Cruz } \\
\text { Cabrália }\end{array}$ & \multicolumn{11}{|c|}{0,654} \\
\hline \multicolumn{4}{|c|}{ EDUCAÇÃO } & SAÚDE & \multicolumn{4}{|c|}{$\begin{array}{c}\text { QUALIDADE } \\
\text { DE VIDA }\end{array}$} & \multicolumn{2}{|c|}{ ECONOMIA } & \multicolumn{2}{|c|}{$\begin{array}{c}\text { ORGANIZAÇÃO } \\
\text { SOCIAL } \\
\end{array}$} & \multirow[b]{2}{*}{ 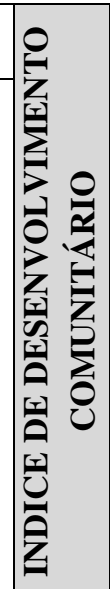 } & \multirow[b]{2}{*}{ 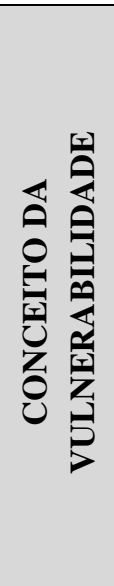 } \\
\hline 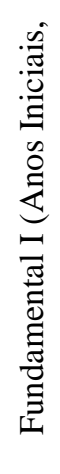 & 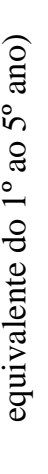 & 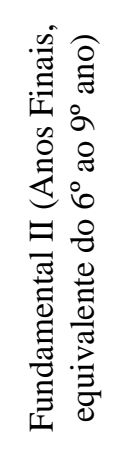 & 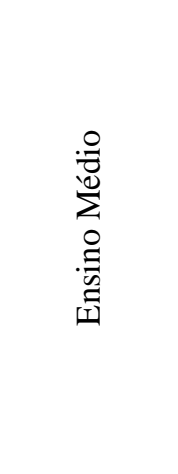 & 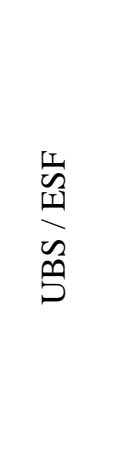 & 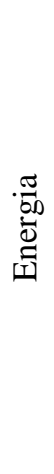 & 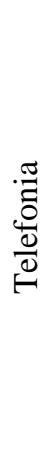 & $\frac{\pi}{\sigma_{0}}$ & 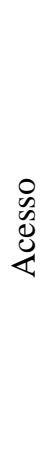 & 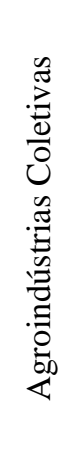 & 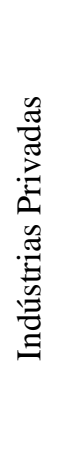 & 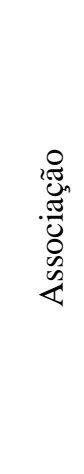 & 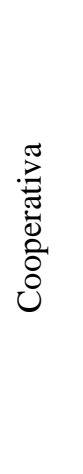 & & \\
\hline$x$ & & $\mathrm{X}$ & $X$ & $X$ & $X$ & $\mathrm{X}$ & $\mathrm{X}$ & $\mathrm{X}$ & $X$ & - & $X$ & - & 6,540 & MÍNIMA \\
\hline
\end{tabular}

FONTE: (IMT/VERACEL, 2015) 
Altemar Felberg - Autonomia e Desenvolvimento Comunitário NO/DO Campo: Contradições e Consensos no Assentamento Luís Inácio Lula da Silva, do Movimento sem Terra - MST - em Santa Cruz Cabrália - Bahia/Brasil

Para cada equipamento disponível, bem como para a presença de instituições que fortalecem o desenvolvimento comunitário, foi atribuída um " $\mathrm{X}$ " que equivale a um ponto. Os pontos atribuídos a cada indicador foram multiplicados pelo Índice de Desenvolvimento Humano do Município de Santa Cruz Cabrália, posição 2012, chegando o Assentamento Luis Inácio Lula da Silva ao conceito de vulnerabilidade MÍNIMA. Os conceitos são enquadrados em: MÁXIMO (0 - 2,796); MÉDIO (2,797 - 5,592) ou MÍNIMO (5,593 - 8,389).

Vale relembrar que os parâmetros ou indicadores para mensurar o nível de vulnerabilidade da comunidade foram baseados no Índice de Pobreza Multidimensional (IPM), criado pelo Programa das Nações Unidas para o Desenvolvimento (PNUD), onde são mensurados indicadores nas áreas de educação (verificando a presença de escolas que atendem o Ensino Fundamental I e II e o Ensino Médio), saúde (verificando presença de unidades básicas de saúde) e qualidade de vida (verificando a disponibilidade de energia elétrica, telefonia, água encanada e acesso). Houve a necessidade de mensurar também o nível economia (presença de agroindústrias coletivas e indústrias privadas) e organização social (presença de associações e cooperativas).

Vejamos agora o grau de satisfação dos assentados, quanto à infraestrutura (comunicação, energia elétrica, estradas/transportes, saúde, lazer e educação) existente no Assentamento Luís Inácio Lula da Silva: acesso e adequabilidade.

\section{Gráfico 14 - Grau de satisfação da infraestrutura local}

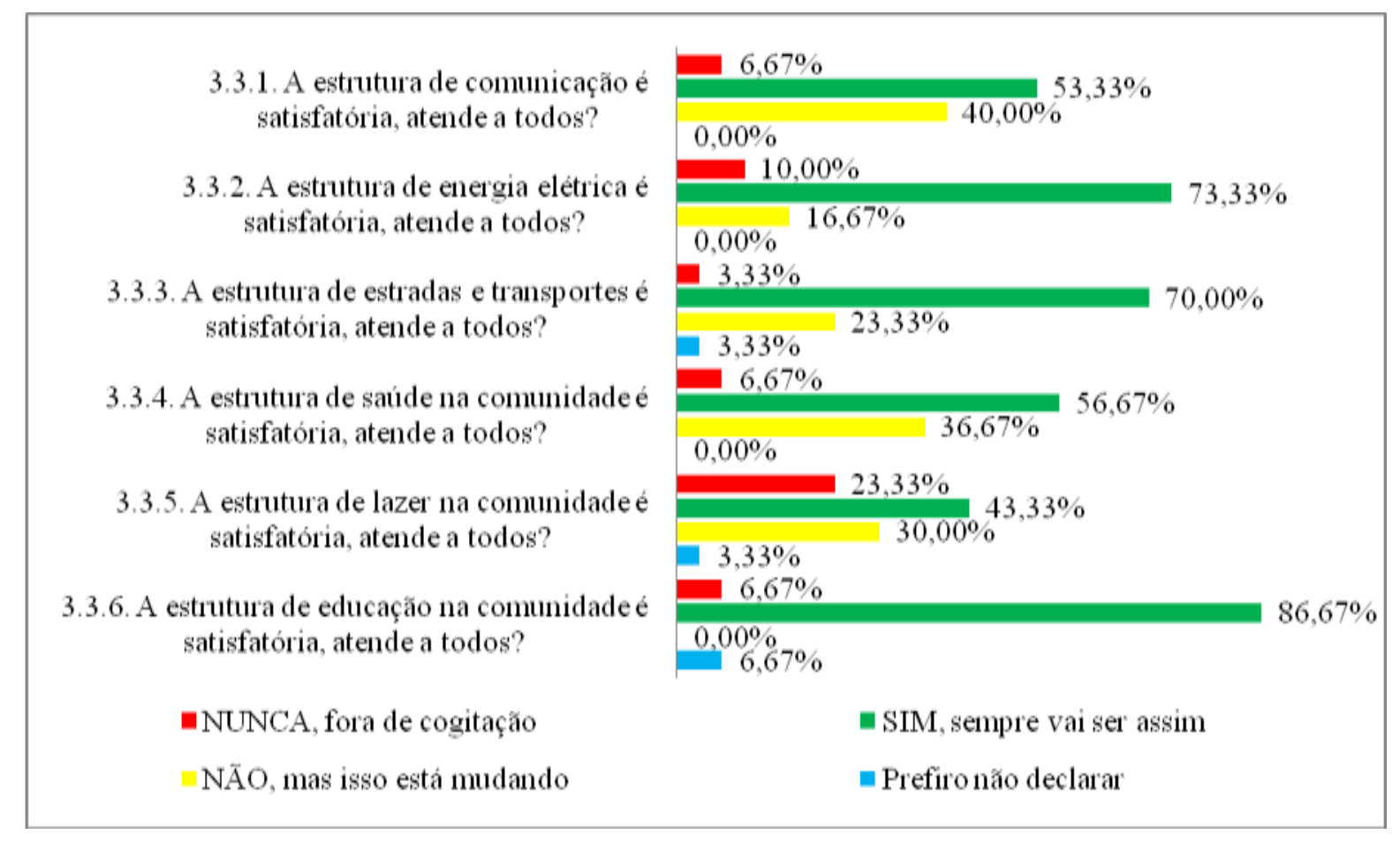

Universidade Lusófona de Humanidades e Tecnologias -FCSEA- Instituto de Educação 
Os indicadores da infraestrutura local estão diretamente relacionados ao desenvolvimento do Assentamento Lulão, pelo menos a parte visível e comumente avaliada, sobretudo por aqueles que dela usufruem. Daí a importância de se realizar sua avaliação junto aos sujeitos, a fim de relacionar suas percepções com o apurado no inventário social.

Em relação à infraestrutura de comunicação, 53,33\% dos sujeitos afirmam ser satisfatória, e $40 \%$ diz que está em melhoramento, o que é confirmado nos relatos: “Tem, todo mundo tem acesso hoje" (BABAÇU, excerto extraído do Grupo Focal $n^{0}$ 02, realizado em maio de 2016, p. 6). "Nós temos internet, telefone, televisão, rádio, boca a boca, bilhete - tudo funciona" (GUARIROBA, excerto extraído do Grupo Focal n ${ }^{\circ}$ 01, realizado em maio de 2016, p. 7).

Referente à disponibilidade e qualidade da infraestrutura de energia elétrica na comunidade, 73,33\% demonstram satisfação, alguns afirmando o seguinte: “Temos sim, luz para todos" (ARECA, excerto extraído do Grupo Focal no 01, realizado em maio de 2016, p. 7). "Tem energia na casa e no lote, dois padrão cada um tem" (GUARIROBA, excerto extraído do Grupo Focal nº 01, realizado em maio de 2016, p. 7).

Quanto à infraestrutura de estradas e transportes, 23,33\% alegam que precisa melhorar. E nos relatos, ouvimos: "A estrada é boa, de dois em dois anos o INCRA dá uma pinceladazinha, às vezes a gente arruma com a prefeitura ali também, pra ajeitar" (GUARIROBA, excerto extraído do Grupo Focal n $n^{\circ}$ 01, realizado em maio de 2016, p. 7). “A escoação é muito boa" (ARECA, excerto extraído do Grupo Focal $n^{\circ} 01$, realizado em maio de 2016, p. 7).

Ao ser questionados acerca da infraestrutura de saúde na comunidade, 36,67\% dos sujeitos disseram que o equipamento disponível não atende a todos, mas que isso está mudando. Estes resultados refletem com fidedignidade a realidade local, uma vez que, como já dissemos, o atendimento em saúde é atualmente realizado de forma provisória, em uma casa coletiva da Associação, enquanto uma grande estrutura de referência em saúde é construída na comunidade, o PSF11, conforme descrito no inventário social e muito bem descrito pelos sujeitos, a exemplo do relato abaixo:

Estamos aí na luta, pra melhorar cada vez mais, né, mas aí a gente já tem uma conquista grandiosa, que é o que nós conseguimos aqui, né, talvez pelo empenho do nome do presidente, aí no assentamento também, né, e a gente dentro dessa luta, que é uma luta desde a formação do movimento também, né, em relação à saúde, e a gente vem melhorando isso a cada dia. Então hoje a gente tem aí o PSF11, né, aqui dentro de uma área de reforma agrária, que isso é uma vitória imensa, porque pelo menos aqui no 
Extremo Sul isso não existe em nenhum outro assentamento, só nesse assentamento, que está tendo pela primeira vez um PSF /.../ Vai atender os pequenos produtores do entorno, uma saúde diferenciada, isso que nós queremos, um atendimento de saúde diferenciado para o homem do campo, que ele é excluído o tempo inteiro [...] a dificuldade do acesso na cidade, por sermos de um município distante [...] então, assim, essa dificuldade de acesso também fez com que a gente lutasse muito mais, então a gente foi aí com a Lei 8.080, garantir que o trabalhador rural, ele também precisa de um atendimento que venha até ele, e não ele ir até o atendimento (ARECA, excerto extraído do Grupo Focal n ${ }^{\circ}$ 01, realizado em maio de 2016, p. 7).

Fica evidente que a conquista da implantação da unidade básica de saúde, dentro do Assentamento, foi resultado de muita luta social e articulação política, por parte das lideranças do MST. O direito básico a uma saúde diferenciada foi reivindicado junto ao governo federal, a fim de atender às especificidades do homem e mulher do campo, que não encontram nos centros urbanos o atendimento adequado à sua condição de trabalhador rural, com todas as suas limitações de locomoção e dificuldades para se manter nas cidades.

No que diz respeito a opções de esporte, lazer e entretenimento dentro da comunidade, 23,33\% são categóricos em afirmar que não atendem aos assentados, mas que está melhorando (30\%), como relatado por um dos sujeitos: "Tá faltando uma área adequada. Agora que vai começar a construção da quadra, que a gente não tinha, e os meninos que treinam futebol ali no campo, só que o campo não é apropriado/.../” (BABAÇU, excerto extraído do Grupo Focal no 02, realizado em maio de 2016, p. 6).

No que diz respeito à infraestrutura de Educação, especificadamente, Guariroba informa:

[...] essa estrutura hoje é uma vitória, porque antes era uma casinha feita de palha de coco, de palmeirão, que a gente pegava na mata aí e fazia a escola. O posto de saúde também era de vara. Começou dando aula debaixo de um pé de árvore, depois fez um barraquinho de palha, depois fez um de lona, e depois temos aí essa estrutura que temos hoje (GUARIROBA, excerto extraído do Grupo Focal no 01, realizado em maio de 2016, p. 8).

Com base no relato acima, é possível saber como se deu a conquista de uma infraestrutura de educação de qualidade e referência dentro do Assentamento. E 86,67\% dos sujeitos demonstram estar satisfeitos, com os resultados. Toda essa conquista representa bem a força da mobilização social e política dos sem-terra, que demonstram buscar, a todo o momento, melhorias para o seu povo. 
Fazendo uso novamente do pensamento de Jazian Santos (2015, p. 28), a história da Escola Paulo Freire se confunde com a própria história do Assentamento Lulão, pois se trata de uma escola construída pela força coletiva, onde "os seus sujeitos se formam e se reformam a cada dia na perspectiva da luta". Este processo de formação, vivenciando a luta e o movimento social, é pautado em formas próprias de organização social e de utilização dos recursos existentes nas próprias áreas de assentamento - na maioria recursos limitados e escassos - como condição para sua reprodução cultural, social e econômica.

Se tomarmos a oferta de serviços públicos (saúde, educação, trabalho etc.) na localidade, como indicador de desenvolvimento local, podemos inferir que o Assentamento Luis Inácio Lula da Silva é desenvolvido, se comparado a outros assentamentos rurais da região. Nas palavras de Guariroba, o Assentamento "é pra ser uma referência; é um negócio lento, demora, mas ainda vai ser uma referência" (GUARIBOBA, excerto extraído do Grupo Focal $n^{\circ}$ 01, realizado em maio de 2016, p. 8). Segundo as lideranças locais, os indicadores de desenvolvimento do Assentamento são resultado da luta, perseverança e determinação do grupo, resultado de uma mobilização coletiva: "quadra, posto, escola, a agroindústria [...] conseguimos" (ARECA, excerto extraído do Grupo Focal nº 01, realizado em maio de 2016, p. 8).

Assim, o modelo de desenvolvimento encontrado no Assentamento Luis Inácio Lula da Silva se aproxima bastante do desenvolvimento como liberdade discutido por Amartya Sen (2008, p. 19), para o qual "[...] a liberdade de participação ou dissensão política ou as oportunidades de receber educação básica, são ou não são conducentes ao desenvolvimento". Também se alinha ao tipo de desenvolvimento defendido por Frank Ellis (2001; 2000 1998), o qual se dá através da combinação de várias ações, iniciativas, escolhas, enfim, práticas e estratégias sociais próprias da comunidade. 
Altemar Felberg - Autonomia e Desenvolvimento Comunitário NO/DO Campo: Contradições e Consensos no Assentamento Luís Inácio Lula da Silva, do Movimento sem Terra - MST - em Santa Cruz Cabrália - Bahia/Brasil

\section{CONSIDERAÇÕES FINAIS}


A pesquisa buscou compreender de que modo os indicadores de desenvolvimento comunitário rural do Assentamento do Movimento dos Trabalhadores Rurais Sem Terra (MST), Luís Inácio Lula da Silva, o Lulão, localizado no município de Santa Cruz Cabrália, Território de Identidade Costa do Descobrimento - Bahia, refletem o grau de autonomia de seus moradores, homens e mulheres do campo. Destaca-se, nesta relação, qual o papel da educação no processo de formação de sujeitos autônomos, como mecanismo promotor da expansão das capacidades e liberdades fundamentais das pessoas, como um recurso capaz de oportunizar condições ideais para que os sujeitos protagonizem suas próprias histórias de desenvolvimento, pessoal e social, sujeitos de ação e reedição.

Em retrovisão histórica da evolução do conceito de autonomia, podemos ponderar que ela não é inata ao ser humano, não se dá apenas na consciência dos sujeitos, mas na dinâmica como o mundo evolui, como o sujeito o enxerga e se posiciona livremente diante dele. Tratase de uma condição a ser conquistada individualmente, pela independência da vontade, a um determinado objeto de desejo, e pela liberdade de ação. E configura-se como a capacidade do indivíduo governar-se conforme uma lei própria, de maneira livre e racional.

Avançando na compreensão do conceito, percebemos que o mesmo sempre se apresentou na literatura acadêmica mundial basicamente vinculado à ideia de participação social e de ampliação da participação e voz de representantes das classes historicamente subalternizadas, nos espaços de discussão política, visando, essencialmente, à descentralização do poder e à construção de um novo modelo de sociedade, que contemplasse, dentre outros aspectos, a ampliação das bases que sustentam a atual democracia e uma ampla transformação econômica, política e social, com igualdade de oportunidades a todo cidadão.

Neste sentido, na perspectiva do desenvolvimento e exercício da autonomia, do 'pensar certo e agir certo' defendido por Freire, podemos considerar os seguintes aspectos: a autonomia depende da interação com seu meio ambiente, seja ele biológico, cultural ou social; ela tem como condições essenciais, a liberdade do sujeito e sua capacidade de ação; está intimamente relacionada com a ideia de 'poder para'; tem a capacidade de transformar 'objetos da história' em 'sujeitos de história', livrando os indivíduos da opressão sobre as suas liberdades de ser, pensar e agir; apresenta-se como um poderoso recurso capaz de livrar os indivíduos não só da submissão a processos opressores e heterônomos, que interferem sobre suas liberdades de escolha e ação, mas também dos quadros de pobreza, desamparo e vulnerabilidade social e econômica; deve ser vivenciada a favor do desenvolvimento e da 
liberdade; e especialmente, é tida na atualidade como umas das mais importantes medidas na avaliação do desenvolvimento.

Abordamos e defendemos, no decorrer de todo este trabalho, um modelo de desenvolvimento pleno, justo e equitativo, construído e avaliado na perspectiva da eliminação de privações de liberdade que limitam as escolhas e as oportunidades das pessoas, de exercerem ponderadamente sua condição de agente, para além dos resultados das variáveis econômicas, a exemplo do aumento de renda, um paradigma de desenvolvimento que se dá a partir do reconhecimento de que a autonomia, desenvolvida na práxis de uma educação libertária, favorece a condição dos indivíduos, de se assumirem como sujeitos socio-históricoculturais, afirmando suas presenças no mundo, não apenas a ele se adaptando, mas se moldando e se humanizando a partir de sua interação com este.

Argumentamos, aqui, que a conquista e sustentabilidade desse modelo de desenvolvimento precisam ser asseguradas em seus vários aspectos, principalmente no da autonomia. Dessa forma, as instituições que se propõem a desenvolver intervenções sociais no campo, particularmente, precisam trabalhar nesta perspectiva humanista, como assim já o fazem as instituições do MST: de trabalhar a autonomia individual e coletiva, não apenas transversalizando conteúdos, reduzindo-a a uma pseudoautonomia discursiva, mas tratando-a como um pilar mestre dos planos, base das ações e do impacto maior que se pretende alcançar.

Ao longo deste trabalho, a todo o momento, procurou-se despertar para a necessidade urgente de uma mudança de comportamento social, a partir do entendimento de que não se pode alcançar o desenvolvimento à custa da privação do outro, de participar, de contribuir e de usufruir do mesmo. E a partir do reconhecimento de que o desenvolvimento é influenciado, inegável e positivamente, pelo acesso às oportunidades econômicas, liberdades políticas, poderes sociais e por condições habilitadoras, com destaque aqui para a educação.

Em se tratando objetivamente dos diversos resultados apurados com esta pesquisa, distribuídos ao longo de todo o trabalho, vale aqui as seguintes considerações:

Ao analisar os processos de autonomia individual e coletiva, traduzida na capacidade dos sujeitos, de conceber e fazer suas próprias escolhas, constatamos que esta é bastante significativa, haja vista o registro de uma alta porcentagem de sujeitos (entre 86,67\% e 100\%) que demonstram decidir autonomamente sobre questões do âmbito da vida privada, levando a vida conforme seus próprios preceitos. Todavia, se analisarmos as demais questões que se relacionam à vida coletiva, notaremos que esta capacidade de pensar e agir, conforme sua 
Altemar Felberg - Autonomia e Desenvolvimento Comunitário NO/DO Campo: Contradições e Consensos no Assentamento Luís Inácio Lula da Silva, do Movimento sem Terra - MST - em Santa Cruz Cabrália - Bahia/Brasil

própria razão e vontade, sofre alteração, especialmente no que se refere à externalização de ideias, opiniões e emoções, havendo um consenso dentro da comunidade, de que a vontade individual cede lugar, voluntariamente, à vontade coletiva, sem aparente pressão externa.

Constatamos, também, que no Assentamento existe uma clara diferenciação entre os objetivos das produções individual e coletiva dentro da área, sem, contudo, ser atribuído qualquer grau de superioridade a um ou a outro, apenas de função. Enquanto a primeira produção está relacionada à composição da renda pessoal e familiar, necessária ao provento das necessidades da família e à busca por uma melhor qualidade de vida, a segunda tem uma função mais social, formativa, voltada à manutenção da cultura do associativismo.

Percebemos, ainda, que existe uma grande defesa dos processos coletivos de produção e de articulação, e mobilização social na reivindicação por políticas públicas, destacando-se a importância da união para a comunidade, a qual é atribuída à maioria dos indicadores de desenvolvimento percebidos: escola, posto de saúde, agroindústria etc. Assim, se tomarmos a oferta de serviços públicos na localidade, como indicador de desenvolvimento local, podemos inferir que o Assentamento Lulão é desenvolvido, se comparado a outros assentamentos rurais da região, como demonstrado no índice e indicadores de desenvolvimento comunitário apresentados neste trabalho, corroborando o desiderato da comunidade, em transformá-lo em referência estadual e nacional.

A despeito dos processos de qualificação profissional, é creditado mérito ao MST, mesmo na busca/realização de cursos privados, ficando claro que as conquistas individuais são resultado da trajetória de participação social no Movimento.

Outra constatação da pesquisa é a de que é praticamente unânime, entre os assentados, a ideia de que a práxis da luta pela terra, pelo trabalho e por condições de uma vida digna, tem relação direta e inseparável com a sua educação e a de seus filhos, com o reconhecimento de que o MST tem influência positiva no modo como eles e seus filhos aprendem e vivem dentro e fora do Assentamento.

Ainda no que diz respeito aos processos de aprendizagem no Assentamento, é consciente entre os sujeitos a existência de uma educação não formal dentro do MST, uma educação que extrapola o espaço escolar, que se dá na dinâmica da vida cotidiana, no exercício da cidadania e na participação social e política. Uma educação que se oportuniza e se concretiza na luta por direitos e no enfrentamento às estruturas de poder e opressão.

Segundo Caldart (2011), este é justamente um dos grandes desafios pedagógicos do MST na atualidade, e uma das principais razões de se valorizar cada vez as estratégias e 
práticas pedagógicas próprias, desencadeadas no interior dos assentamentos e acampamentos: tornar consciente e reflexivo este processo de aprendizagem que se dá na trajetória de luta.

Confirmamos que a educação, seja formal ou não, tem especial relevância e influência no desenvolvimento sócio-econômico-cultural e ambiental do Assentamento, destacando-se o princípio educativo do próprio MST, como agente promotor da expansão das liberdades e capacidades dos sem-terra, formando-os para a autonomia e para o exercício da cidadania.

Uma última constatação é a de que há intensa e qualificada participação e envolvimento de todo o contingente comunitário nos assuntos de interesse coletivo - homens, mulheres, idosos, crianças, adolescentes e jovens. À mulher, é assegurado seu espaço igualitário em todos os processos de luta, às vezes com destaque; aos idosos, é valorizada e atribuída a responsabilidade por garantir as áreas de assentamento, quando dos processos de ocupação de terras, pelo MST; e aos jovens é dado apoio à participação, e incentivada cada vez mais a busca pela formação e qualificação, visando a sua permanência no campo e sua afirmação identitária como sem-terra.

A pesquisa também revela que uma das estratégias para o desenvolvimento e sua avaliação é a importância e valorização da participação e da autonomia dos indivíduos, transformando-os em sujeitos de ação, o que pode ser entendido como a busca de um maior grau de conscientização e interferência no processo de dinamização socioeconômica e cultural da localidade, através da ação coletiva e organizada.

Por conseguinte, enfatizamos aqui que, é através de uma participação decisória e integrada de amplos contingentes da população local, que é possível aproveitar o saber-fazer tradicional, o conhecimento detalhado da realidade e a vontade consciente de agir dos atores sociais. Uma participação não restrita aos indivíduos, que possuem 'maior poder relacional', a exemplo das lideranças formais, mas que contemple, principalmente, aqueles mais vulneráveis, evitando, desta forma, a 'reprodução das assimetrias de poder'.

Fica, então, evidenciado nos resultados aqui apresentados, seja no sentido da autonomia para os sujeitos, seja na dimensão social desta, que os indicadores de desenvolvimento da comunidade têm relação direta com o elevado grau de autonomia de seus moradores. Uma autonomia forjada no próprio espaço de vivência, construída na práxis da luta por direitos e por uma vida digna, utilizada a favor da coletividade, da vida comum.

Especialmente no que diz respeito a esta educação de que falamos, seu direito e acesso qualificado, destacamos aqui sua especificidade nesta pesquisa. Uma educação do campo, forjada na arena da luta de classes, que nasceu essencialmente como crítica à realidade do 
sistema educacional do país, particularmente à situação educacional da população brasileira que trabalha e vive no/do campo, uma população ainda discriminada e marginalizada. Um manifesto por uma educação não periférica à das cidades, que considere a singularidade do modo de vida do homem e mulher do campo, sua história, valores, cultura e identidade, e que desmistifique o campo como lugar atrasado, obsoleto e fadado à extinção. Uma crítica não apenas à educação, mas ao modelo de sistema econômico capitalista e sua injusta distribuição de renda, que incentiva o agronegócio e a expropriação de terras tradicionais; à elitização do acesso à ciência, à tecnologia, à cultura e às suas produções. Enfím, críticas a não universalização de direitos que garantem a plena cidadania;

Ainda, nossa defesa aqui, para além da educação como um direito humano, que deve ser emergencialmente efetivado, é que não é mais possível conceber e aceitar o desenvolvimento sem pensá-lo atrelado à ideia de promoção da autonomia dos sujeitos e à ampliação de suas capacidades e liberdades fundamentais, sem dar-lhes condições para a conquista do poder como o conhecimento que possibilita a percepção crítica da realidade e a reação frente às injustiças e desigualdades sociais, sem destacar a diversidade cultural e o respeito à diferença como importantes medidas de avaliação no processo desenvolvimentista, sem possibilitar que as populações tradicionais excluídas consigam se descobrir e se assumir como capazes de traçarem suas trajetórias de desenvolvimento. E é nesse movimento de ruptura, de ação, que a democratização da educação mostrou-se, ao longo da história, ser uma importante frente de luta na busca pela universalização da cidadania.

Diante do exposto nessa pesquisa, fica a intenção de ressoar a voz dos companheiros coautores deste trabalho, repercutindo o desejo de um grupo que brada um pedido de respeito a uma população historicamente subjugada. Um discurso a favor desta educação que denuncia, de forma contundente, as heteronomias do sistema, e que incita, em todos nós, homens e mulheres que vivenciam a ética universal do ser humano, a nos unirmos a este movimento, a promovermos e reivindicarmos esta educação que liberta e transforma, como constatamos nos resultados aqui apresentados, que leva em consideração e respeita a autonomia do sujeito, e que promove sua emancipação.

Neste contexto, é preciso que as várias instituições que atuam nestas comunidades, sejam elas públicas ou privadas, ofereçam subsídios para que estes grupos se reconheçam e se assumam como sujeitos de direitos e agentes poderosos de transformação social, capazes de protagonizar autonomamente suas histórias de desenvolvimento, a partir da maximização das potencialidades existentes na própria localidade, visto que as estratégias que normalmente 
Altemar Felberg - Autonomia e Desenvolvimento Comunitário NO/DO Campo: Contradições e Consensos no Assentamento Luís Inácio Lula da Silva, do Movimento sem Terra - MST - em Santa Cruz Cabrália - Bahia/Brasil

geram impactos e mudanças sociais significativos na melhoria das condições de vida das populações rurais, e que ampliam suas perspectivas de garantir sua reprodução social, cultural e econômica estão, comprovadamente, nas próprias localidades e territórios onde vivem.

A partir do exposto, sobre autonomia e desenvolvimento, acreditamos que não há como desassociar a formação para a autonomia, a busca ou a promoção do empoderamento, com a possibilidade de oportunizar a indivíduos ou grupos de indivíduos o acesso aos direitos universais do ser humano, a exemplo de uma educação libertária. Nesta perspectiva, partimos do pressuposto de que o investimento no atendimento às necessidades humanas básicas melhora a produtividade e o crescimento econômico rumo à instauração de um modelo de desenvolvimento ético, que implica a garantia de direitos constitutivos da cidadania, capazes de promover maiores e melhores condições de reflexão e ação. 
Altemar Felberg - Autonomia e Desenvolvimento Comunitário NO/DO Campo: Contradições e Consensos no Assentamento Luís Inácio Lula da Silva, do Movimento sem Terra - MST - em Santa Cruz Cabrália - Bahia/Brasil

\section{REFERÊNCIAS}


ABBAGNANO, Nicola. Dicionário de Filosofia. Trad. Alfredo Bosi. $2^{a}$ ed. São Paulo: Mestre Jou, 1962.

ABBAGNANO, Nicola. Dicionário de Filosofia. Trad. Alfredo Bosi. $5^{\text {a }}$ ed. São Paulo: Martins Fontes, 2007. 1210 p.

ABRAMOVAY, R. Agricultura familiar e desenvolvimento territorial. Brasília: MDA, NEAD, Consultoria IICA 940/98, 1998.

ABRAMOVAY, R. O capital social dos territórios: repensando o desenvolvimento rural. Economia Aplicada. V. 4, n 2, abril/junho. 2000.

ABRAMOVAY, R. Relatório Institucional da Secretaria da Agricultura Familiar. Brasília: PNUD, Projeto BRA-98/012, junho/2002, Relatório de Pesquisa.

ADORNO, Theodor W. Textos Escolhidos. Trad. Luiz João Baraúna. São Paulo: Nova Cultural, 1999. (Os Pensadores)

AMARO, R. R. Descentralização e desenvolvimento em Portugal: algumas perspectivas, tendo especialmente em conta a questão da educação. In: BARROSO, J.; PINHAL, J. (Org.). A administração da educação: os caminhos da descentralização. Lisboa: Colibri, 1996.

AMMANN, Safira Bezerra. Ideologia do Desenvolvimento Comunitário no Brasil. São Paulo: Cortez, 1981.

ARAÚJO, Maria Nalva Rodrigues de. As Contradições e as Possibilidades de Construção de uma Educação Emancipatória no Contexto do MST. 2007. 334f. Tese (Dourado em Educação) - Universidade Federal da Bahia, Faculdade de Educação 2007. Disponível em: <http://www.repositorio.ufba.br:8080/ri/handle/ri/10599>. Acesso em: 30 Mai. 2016.

ARROYO, Miguel Gonzalez e FERNANDES, Bernardo Mançano. A educação básica e o movimento social do campo. Brasília, DF: Articulação Nacional Por Uma Educação Básica do Campo, 1999. Coleção Por Uma Educação Básica do Campo, n. ${ }^{\circ} 2$.

ARROYO, Miguel Gonzalez et al. Por uma educação do campo. Petrópolis, RJ: Vozes, 2004.

BAQUERO et. al. Para além de Capital Social - juventude, empoderamento e cidadania. p. 1-19. Disponível em <http://www.capitalsocialsul.com.br/capitalsocialsul/desenvolvimentoregional/Grupo\%202/1 8.pdf>. Acesso em: 17 abr. 2008.

BARDIN, Laurence. Análise de conteúdo. Lisboa: Edições 70, 1979.

BATISTA, Maria do Socorro Xavier. Movimentos sociais, estado e políticas públicas de educação do campo: pesquisa e práticas. João Pessoa: UFPB, 2011.

BAUMAN, Zygmunt. Comunidade - a busca por segurança no mundo atual. Tradução: Plínio Dentzien. Rio de Janeiro: Jorge Zahar Ed., 2003. 
BOBBIO, N. O Futuro da democracia. São Paulo: Brasiliense, 2000.

BOURRICAUD, François. Autonomie. In: Encyclopaedia Universalis - Vol. 3. Paris: France S.A., 1985.

BUARQUE, Sérgio C. Metodologias do planejamento do desenvolvimento local e municipal sustentável. 2. ed. Recife: IICA, 1999.

- Metodologia de planejamento do desenvolvimento local e municipal sustentável: Material para orientação técnica e treinamento de multiplicadores e técnicos em planejamento local e municipal. Apodesc. Disponível em: < http://www.apodesc.org/sites/documentos_estudos/arquivos/PlanejMetodologia\%20de\%20planejamento\%20do\%20desenvolvimento\%20local\%20e\%20municip al\%20sustentavel-Sergio\%20Buarque.pdf>. Acesso em: 19 jul. 2011.

BRASIL. Constituição (1934). Constituição da República dos Estados Unidos do Brasil. Rio de Janeiro, 1934. 1937. . Constituição (1937). Constituição dos Estados Unidos do Brasil. Rio de Janeiro, . Constituição (1946). Constituição dos Estados Unidos do Brasil. Rio de Janeiro, 1946.

Lei de Reforma Agrária (Lei no 4504/64). Brasília, 1964. 1967. Constituição (1967). Constituição da República Federativa do Brasil. Brasília, . Constituição (1988). Constituição da República Federativa do Brasil. Brasília, DF: Senado Federal: Centro Gráfico, 1988. 292 p.

Ministério da Educação. Conselho Nacional de Educação. Diretrizes operacionais para a Educação Básica nas Escolas do Campo. Brasília, DF, 2001.

Ministério da Educação. Grupo de Trabalho de Educação do Campo. Referências para uma política nacional de educação do campo. Caderno de Subsídios, Brasília, DF, 2003.

Discurso do Presidente da República, Luiz Inácio Lula da Silva, na visita ao Assentamento Lulão. Disponível em: < http://www.biblioteca.presidencia.gov.br/presidencia/ex-presidentes/luiz-inacio-lula-dasilva/discursos/1o-mandato/2005/28-09-2005-discurso-do-presidente-da-republica-luizinacio-lula-da-silva-na-visita-ao-assentamento-201clulao201d>. Acesso em: 07 mar. 2016.

BRAUDEL, Fernand. Civilização material, economia e capitalismo: séculos XV a XVIII. São Paulo: Martins Fontes, 1996.

CALDART, Roseli Salete. Educação em Movimento: Formação de educadores e educadoras no MST. Petrópolis, RJ: Vozes, 1997. 
. A escola do campo em movimento. Contexto e Educação, Ijuí, v.15, 2000.

Pedagogia do Movimento Sem-Terra. Petrópolis: Vozes, 2000.

Pedagogia do Movimento Sem-Terra. São Paulo: Expressão Popular, 2004.

MST e a formação dos sem terra: o movimento social como princípio educativo.

Estud. av. vol.15 no 43. São Paulo: Set./Dec. 2001. Disponível em:

<http://www.scielo.br/scielo.php?script=sci_arttext\&pid=S0103-40142001000300016>.

Acesso em: 11 nov. 2009.

Por uma Educação do Campo: traços de uma identidade em construção. In: Por uma educação básica no campo: Identidade e políticas públicas. V. 4. Brasília, 2002, p.25-36.

Educação do Campo: notas para uma análise de percurso. Trab. educ. saúde, Rio de Janeiro, v. 7 n. 1, p. 35-64, mar./jun.2009. Disponível em: <

http://www.scielo.br/pdf/tes/v7n1/03.pdf>. Acesso em: 20 out. 2015.

CANZONIERI, Ana Maria. Metodologia da pesquisa qualitativa na saúde. Petrópolis, RJ: Vozes, 2010.

CASTEL, R. As metamorfoses da questão social: uma crônica do salário. Petrópolis: Vozes, 1998.

CASTORIADIS, C. A instituição imaginária da sociedade. Rio de Janeiro: Paz e Terra, 1982.

A Instituição imaginária da sociedade. Rio de Janeiro: Paz e Terra, 1991.

As Encruzilhadas do Labirinto III: o mundo fragmentado. Trad. Rosa Maria Boaventura. Rio de Janeiro: Paz e Terra, 1992.

As Encruzilhadas do Labirinto VI. Rio de Janeiro: Civilização Brasileira, 2004.

CAYGILL, Howard. Dicionário Kant. Trad. Álvaro Cabral. Rio de Janeiro: Jorge Zahar, Ed., 2000.

CHAUÍ, Marilena de Souza. Cultura e Democracia: o discurso competente e outras falas. $5^{\text {a }}$ ed. Cortez Editora. São Paulo, 1990.

Convite à Filosofia. São Paulo: Átila, 2000.

COELHO, Ricardo Corrêa. Estado, Governo e Mercado. Florianópolis: Departamento de

Ciências da Administração / UFSC; Brasília: CAPES: UAB, 2009.

CORTINA, Adela. Ética sem moral. São Paulo: Martins Fontes, 2010.

CURY, Carlos Roberto J. Direito à educação: direito à igualdade, direito à diferença, Cadernos de pesquisa, n.116, p.245-262, julho/ 2002. Disponível em: $<$ http://www.scielo.br/scielo.php?script=sci_arttext\&pid=S0100-15742002000200010>. 
DAGNINO, Evelina. Políticas culturais, democracia e projeto neoliberal. In: Rio de Janeiro, (15): 45-65, janeiro / abril de 2005. Disponível em: <http://www.forumrio.uerj.br/documentos/revista_15/15_dossie_EvelinaDagnino.pdf.. Acesso em: 13 fev. 2016.

DOWBOR, Ladislaw. A Reprodução Social. Petrópolis, Vozes, 1998.

DURIGUETTO, Maria Lúcia. Democracia: Polêmicas, confrontos e direcionamentos. Tese de Doutorado. Programa de Pós-Graduação em Serviço Social da Escola de Serviço Social da UFRJ, 2003.

DIEHL, Astor Antonio. Pesquisa em ciências sociais aplicadas: métodos e técnicas. São Paulo: Prentice Hall, 2004.

ESTEVA, Gustavo. Desenvolvimento. In: SACHS, Wolfgang (editor). Dicionário do Desenvolvimento: guia para o conhecimento como poder. Tradutores: Vera Lúcia M. Joscelyne, Susana de Gyalokai, Jaime A. Clasen. Petrópolis: Vozes, 2000, p. 59-83.

FAGUNDES, Tereza Cristina Pereira Carvalho. Metodologia da pesquisa - Especialização em EAD. Salvador: UNEB/EAD, 2010.

FAVARETO, Arilson da Silva. Paradigmas do desenvolvimento rural em questão - do agrário ao territorial. São Paulo: USP, 2006.

FERNANDES, Bernardo Mançano. Diretrizes de uma caminhada. In: Por uma educação básica no campo: Identidade e políticas públicas. V. 4. Brasília, 2002, p.89-101.

FERNANDES, Florestan. A revolução burguesa no Brasil. Globo. 2006.

FERRATER MORA, José. Dicionário de Filosofia - Vol. 1 Buenos Aires: Sudamericana, 1965.

FREIRE, Paulo. Educação como prática da liberdade. $7^{\mathrm{a}}$ ed. Rio de Janeiro: Paz e Terra, 1977.

Conscientização: teoria e prática da libertação: uma introdução ao pensamento de Paulo Freire. 3. ed. São Paulo: Centauro, 1980. 102 p.

Pedagogia do Oprimido. 12ª ed. Rio de Janeiro: Paz e Terra, 1983.

Pedagogia da autonomia: saberes necessários à prática educativa (Coleção Leitura). São Paulo, SP: Paz e Terra, 1996.

Pedagogia da autonomia - saberes necessários à prática educativa. 36. ed. Rio de Janeiro: Paz e Terra, 2007.

FREIRE, Paulo; SHOR, Ira. Medo e ousadia: o cotidiano do professor. Rio de Janeiro: Paz e Terra, 1986. 
FREY, K. 2000. Políticas públicas: um debate conceitual e reflexões referentes à prática da análise de políticas públicas no Brasil. Planejamento e Políticas Públicas, Rio de Janeiro, n. 21, p. 211-259. Disponível em:

http://www.ipea.gov.br/ppp/index.php/PPP/article/viewFile/89/158. Acesso em: 12 jul. 2011.

GIL, A. C. Como elaborar projetos de pesquisa. $4^{\text {a }}$ Ed. São Paulo: Atlas, 2007.

GOLDIM, José Roberto. Princípio do respeito à pessoa ou da autonomia. Bioética e Ética na Ciência: UFRGS, 2004. Disponível em <http://www.ufrgs.br/bioética/autonomi.htm〉. Acesso em: 12 jul. 2011.

GOHN, Maria da Glória. Novas teorias dos movimentos sociais. 2. ed. São Paulo: Loyola, 2009.

GRAZIANO DA SILVA, J. O que Há de Realmente Novo no Rural Brasileiro? Cadernos de Ciência e Tecnologia, Brasília, v. 19, n. 1, p.37-67, jan./ abr. 2002.

HAESBAERT, R. Des-territorialização e identidade: a rede "gaúcha" no nordeste. Niterói: EdUFF, 1997.

HAESBAERT, R. Territórios Alternativos. Niterói: EdUFF e São Paulo: Contexto,2002.

JESUS, Edilza Laray de. Educação e desenvolvimento em áreas agrícolas no amazonas. 2009. 194 f. Tese (Doutorado em Educação) - Universidade Federal do Rio Grande do Sul, Porto Alegre, 2009. Disponível em: < http://repositorio.minedu.gob.pe/bitstream/handle/123456789/536/2009_Jesus_Educa\%C3\% A7\% C3\% A3o\%20e\%20desenvolvimento\%20em\%20\%C3\%A1reas\%20agr\%C3\%ADcolas\% 20no\%20Amazonas.pdf?sequence=1\&isAllowed=y>. Acesso em: 05 Ago. 2010.

KANT, Immanuel (1785). Fundamentação da metafísica dos costumes. In: Os pensadores. São Paulo: Abril Cultural, 1974.

Crítica da Razão Pura. In: Os pensadores. Trad. Valério Rohden e Udo Valdur Moosburger. São Paulo: Nova Cultural, 1996.

. Resposta à pergunta: Que é "esclarecimento" (Aufklärung). In: Textos Seletos. Trad. Floriano de Souza Fernandes. 3ª ed. Petrópolis: Vozes, 2005.

Crítica da Razão Prática; tradução baseada na edição original de 1788, com introdução e notas Valério Rohden. 3. ed. São Paulo: WMF Martins Fontes, 2011.

LALANDE, ANDRÉ. Vocabulário Técnico e Crítico da Filosofia. $3^{\mathrm{a}}$ ed. São Paulo: Martins Fontes, 1999.

LAVILLE, Christian; DIONNE, Jean. A construção do saber: manual de metodologia da pesquisa em ciências humanas. Tradução de Heloísa Monteiro e Francisco Settineri. Porto Alegre: Artmed, 1999. 
LEOPOLDI, José Sávio. Rousseau: estudo de natureza, o "bom selvagem" e as sociedades indígenas. Revista ALCEU, Rio de Janeiro: Ed. PUC-Rio, v. 2, n. 4, p. 158-172, jan./jun. 2002. Disponível em:

< http://revistaalceu.com.puc-rio.br/media/alceu_n4_Leopoldi.pdf> Acesso em: 20 Out. 2015.

LIMA, Ivaldo. Território Autonômico como Sistema. Revista Geográfica de América

Central. Número Especial EGAL, 2011 - Costa Rica II Semestre 2011 pp. 1-15.

LOCKE, John. Segundo Tratado sobre o Governo. Trad. Anoar Aiex e E. Jacy Monteiro. 3. Ed. São Paulo: Abril Cultural, 1983 (Os Pensadores).

LYRA, Carla. Ação política e autonomia: a cooperação governamental para o desenvolvimento. São Paulo: Annablume, 2005.

MARCUSCHI, L. A. Análise da conversação. São Paulo: Ática, 1986.

MARTINS, Ângela Maria. Autonomia e gestão da escola pública: entre a teoria e a prática. 2001. 312 f. Tese (Doutorado em Educação) - Universidade Estadual de Campinhas, 2001.

Autonomia e educação: a trajetória de um conceito. Cadernos de Pesquisa, n. 115, março/ 2002.

MÉO, G. Di. Géographie sociale et territoires. Paris: Éditions Nathan, 1998.

MOLINA, Mônica Castagna (Org.). Brasil. Ministério do Desenvolvimento Agrário.

Educação do Campo e Pesquisa: questões para reflexão. - Brasília: Ministério do

Desenvolvimento Agrário, 2006.

MORGAN, D. L. (1996). Focus group. Annual Review Sociology, 22, 129-152.

MORGAN, D. L. (1997). Focus group as qualitative research (2nd ed.). Thousand Oaks, Califórnia: Sage.

MORIN, Edgar. A cabeça bem - feita. Rio de Janeiro: Bertrand - Brasil, 2002.

A cabeça bem-feita: repensar a reforma, reformar o pensamento. Tradução de Eloá Jacobina. 12. ed. Rio de Janeiro: Bertrand Brasil, 2006.

Introdução ao pensamento complexo. 3. ed. Porto Alegre: Sulina, 2007.

MILL. John Stuart. Considerações sobre o governo representativo. Trad. Manoel Inocêncio de L. Santos Jr. Brasília: UnB, 1980. (Pensamento Político 19)

NAVARRO, Z. Desenvolvimento rural no Brasil: os limites do passado e os caminhos do futuro. Revista Estudos Avançados, São Paulo, USP, Vol. 16, nº 44, 2001.

NISBET, R. História da ideia de progresso. Brasília: UnB, 1985.

NÓVOA et al. Formação para o desenvolvimento, Lisboa, Fim de Século, 1992. 
NUSSBAUMER, Gisele Marchiori. Teorias e políticas da cultura: visões multidisciplinares. Salvador: edufba, 2007.

OAKLEY, Peter; CLAYTON, Andrew. Monitoramento e avaliação do empoderamento (“empowerment"). Tradução de Zuleika Arashiro e Ricardo Dias Sameshima. São Paulo: Instituto Pólis, 2003.

OLIVEIRA, Naiana Alves et. al. Contextualizando o grupo focal: técnica de coleta de dados em pesquisa qualitativa. XVII Congresso de Iniciação Científica: X Encontro de Pósgraduação. UFPEL. 2008, São Paulo: UNIFESP, 2009. Disponível em <http://www.ufpel.edu.br/cic/2008/cd/pages/pdf/cs/cs_01573.pdf. Acesso em: 18 jul. 2011.

ONU - Organização das Nações Unidas. Declaração Universal dos Direitos Humanos. 1948.

ONU - Organização das Nações Unidas. Pacto Internacional dos Direitos Econômicos, Sociais e Culturais. 1966.

PEREIRA, Miguel Ribeiro. A inclusão da autonomia como indicador de desenvolvimento humano diante da formação da social brasileira. Jornada Internacional de Políticas Públicas (JOINPP). III Jornada Internacional de Políticas Públicas. São Luís - MA, 28 a 30 de agosto 2007.

PEREIRA, Rosilene de Oliveira. Liberdade e Moralidade. Revista Cultura. Disponível em <http://www.unopar.br/portugues/revfonte/v3/art9/art9.html>. Acesso em: 13 jul. 2011.

PLOEG J.D. van der et alii. Rural Development: from practices and policies towards theory. Sociologia Ruralis, Netherlands, 40 (4): 391-407, 2000.

PLOEG J.D. van der and RENTING, H. Impact and potential: a comparative review of European rural development practices. Sociologia Ruralis, Netherlands, 40 (4): 529-543, 2000 .

PINZANI, Alessandro. De objeto de políticas a sujeitos da política: dar voz aos pobres. ethic@ - Florianópolis, v. 10, n. 3, p. 83 - 101, Dez. 2011.

RAFFESTIN, C. Por uma geografia do poder. São Paulo: Ática, 1993.

REALE, Giovanni; ANTISERI, Dario. História da Filosofia: Do Humanismo a Kant. São Paulo: Paulus, 1990.

RICHARDSON, Roberto Jarry et al. Pesquisa social: métodos e técnicas. São Paulo: Atlas, 1999.

ROVER; Oscar José; HENRIQUES, Maria Adosinda. O Programa LEADER em Portugal e a restrita autonomia dos atores locais. Sober. 2005. Disponível em <http://www.sober.org.br/palestra/2/1078.pdf>. Acesso em: 29 jul. 2011. 
ROUSSEAU, Jean-Jacques (1762). Do contrato social. Trad. Lourdes Santos Machado. Introdução e notas de Paulo Arbousse-Bastide e Lourival Gomes Machado. - $2^{\mathrm{a}}$ edição - São Paulo: Abril Cultural, 1978. (Os Pensadores).

1995.

Emílio ou Da Educação. Trad. Sérgio Milhet. $3^{\mathrm{a}}$ ed. Rio de Janeiro: Bertrand Brasil,

SACHS, Wolfgang (editor). Dicionário do Desenvolvimento: guia para o conhecimento como poder. Tradutores: Vera Lúcia M. Joscelyne, Susana de Gyalokai, Jaime A. Clasen. Petrópolis: Vozes, 2000.

SANTOS, Boaventura de Souza. Os processos da Globalização. In: A Globalização e as Ciências Sociais. São Paulo: Cortez, 2002. p. 25-102.

2005.

Pela mão de Alice: o social e o político na pós-modernidade. Sao Paulo: Cortez,

SANTOS, Cláudia Araujo dos. A autonomia da escola: a visão dos governos e dos profissionais da educação. 2005. 152 f. Dissertação (Mestrado em Educação) - Universidade Federal Fluminense, Niterói, 2005.

SANTOS, Jazian Mota dos. Agroecologia na Escola Municipal Paulo Freire Santa Cruz Cabrália BA: estudo da relação comunidade escola. São Paulo: USP, 2015.

SEREVI, Fabiana Cristina. Experiência, memória e autonomia em um assentamento de reforma agrária na região de Ribeirão Preto-SP. 2010. 312 f. Tese (Doutorado em Psicologia e Educação) - Universidade de São Paulo, 2010. Disponível em: $<w w w . t e s e s . u s p . b r / t e s e s / d i s p o n i v e i s / 59 / 59137 / t d e-09082010-150435 / . . / F a b i a n a t e s e . p d f$. Acesso em: 14 Nov. 2012.

SOUZA, Lílian. Terra dos Homens: gênese do MST-BA. Monografia de conclusão de curso de Comunicação/UFBA, 2004.

SOUZA, Matias Gonzáles. A Arte da Sedução Pedagógica na Tutoria em Educação a Distância. Núcleo de Educação à Distância - UNISAL. Disponível em <http:// http://www.abed.org.br/congresso2004/por/htm/001-TC-A1.htm>. Acesso em: 18 jul. 2011.

SAHD, Luiz Felipe Netto de Andrade e Silva. A Noção de Liberdade no Emílio de Rousseau. Trans/Form/Ação, São Paulo, 28(1): 109-118, 2005.

SCHWEPPENHÄUSER, Gerhard. A filosofia moral negativa de Theodor W. Adorno. Scielo. Tradução de Antônio A. S. Zuin, Fábio A. Durão e Newton Ramos de Oliveira. 2003. Disponível em < http://www.scielo.br/pdf/es/v24n83/a04v2483.pdf >. Acesso em: 19 jul. 2011.

SCHNEIDER, Sergio. A abordagem territorial do desenvolvimento rural e suas articulações externas. Sociologias, Porto Alegre, ano 6, n. 11, p. 88-125, jan./jun. 2004. Disponível em <http://www.scielo.br/pdf/soc/n11/n11a06.pdf>. Acesso em: 17 abr. 2008. 
SEN, Amartya Kumar. Desenvolvimento como liberdade. Tradução de Laura Teixeira Motta; revisão técnica Ricardo Doniselli Mendes, São Paulo: Companhia das Letras, 2008.

SILVA, Maria Teresa Ramos da; ARNS, Paulo César. Desenvolvimento Comunitário. Empreende. Projeto BNDES - Desenvolvimento Local - Cooperação Técnica do Programa das Nações Unidas para o Desenvolvimento (PNUD). 2002. Disponível em <http://www.empreende.org.br/pdf/Programas\%20e\%20Pol\%C3\%ADticas\%20Sociais/Dese nvolvimento\%20Comunitario.pdf>. Acesso em: 19 jul. 2011.

SILVA, André Gustavo Ferreira da. O conceito de Liberdade (Freiheit) como fundamento da noção de Educação (Bildung) em Hegel. Revista Sul-Americana de Filosofia e Educação. Número 17: nov/2011-abr/2012, p. 3-13.

TAYLOR, Charles. As Fontes do Self: A construção da identidade moderna. Trad. Adail Ubirajara Sobral e Dinah de Abreu Azevedo. São Paulo: Editora Loyola, 1997.

TEODORO, António. A educação em tempos de globalização neoliberal: os novos modos de regulação das políticas educacionais. Brasília: Liber Livro, 2011. 176p.

VALENTE, Ana Lúcia E.F. Nas barbas do Planalto: o Núcleo Rural Monjolo e a extensão rural no DF. Scribd. Disponível em < http://pt.scribd.com/doc/60186818/Ana-Valente>. Acesso em: 17 jul. 2011.

VENDRAMINI, Célia Regina. Terra, trabalho e educação: experiências sócio-educativas em assentamentos do MST. Ijuí, Editora Unijuí, 2000.

VEIGA, José Eli da. Desenvolvimento Sustentável: o desafio do século XXI. Rio de Janeiro: Garamond, 2005.

Meio Ambiente e desenvolvimento. São Paulo: SENAC, 2006.

WARRY, Ana Paula Salvador; RUIZ, Adriano Rodrigues. Autonomia como objetivo na educação. Revista Urutágua/UEM. Disponível em

<http://www.urutagua.uem.br/autonomia.htm>. Acesso em: 18 jul. 2011.

WEBER, Max. Economia e Sociedade. Brasília, UNB, 1972, vol. I.

WEBER, Thadeu. Autonomia e Consenso Sobreposto em Rawls. ethic@ - Florianópolis, v. 10, n. 3, p. 131 - 153, Dez. 2011.

WEIGAND JUNIOR, R.; VIANA, C. F. G.; SHIKI, S. F. N.; DUNCAN, M.; ENEIAS, L. Experiências brasileiras de desenvolvimento territorial rural sustentável. In: Fórum

Internacional Território, Desenvolvimento Rural e Democracia, 1., Fortaleza, 2003.

ZATTI, Vicente. A educação para a autonomia em Immanuel Kant e Paulo Freire. 2007. 100f. Dissertação (Mestrado em Filosofia da Educação) - Universidade Federal do Rio Grande do Sul, Porto Alegre, 2007. 
Altemar Felberg - Autonomia e Desenvolvimento Comunitário NO/DO Campo: Contradições e Consensos no Assentamento Luís Inácio Lula da Silva, do Movimento sem Terra - MST - em Santa Cruz Cabrália - Bahia/Brasil

\section{APÊNDICE}


Altemar Felberg - Autonomia e Desenvolvimento Comunitário NO/DO Campo: Contradições e Consensos no Assentamento Luís Inácio Lula da Silva, do Movimento sem Terra - MST - em Santa Cruz Cabrália - Bahia/Brasil
A - Inventário Social
B - Matriz de Vulnerabilidade Social
C - Questionário Individual
D - Roteiro Entrevistas com Grupos Focais 